
THE UNIVERSITY OF MICHIGAN CENTER FOR SOUTH AND SOUTHEAST ASIAN STUDIES

THE MICHIGAN SERIES IN SOUTH AND SOUTHEAST ASIAN LANGUAGES AND LINGUISTICS

Editorial Board

Alton L. Becker

John K. Musgrave

George B. Simmons

Thomas R. Trautmann, chm.

Ann Arbor, Michigan 



\section{CRITICAL STUDIES IN \\ INDIAN GRAMMARIANS I: \\ THE THEORY OF HOMOGENEITY \\ [SAVARNYA]}

Madhav Deshpande

Ann Arbor

Center for South and Southeast Asian Studies

The University of Michigan

1975

The Michigan Series in South and Southeast Asian

Languages and Linguistics, 2 
Open access edition funded by the National Endowment for the Humanities/ Andrew W. Mellon Foundation Humanities Open Book Program.

Library of Congress Catalog Card Number: 75-36896 International Standard Book No. 0-89148-052-8

\title{
Copyright 1975
}

by

Center for South and Southeast Asian Studies

The University of Michigan

Printed in the United States of America

\author{
ISBN 978-0-89148-052-5 (paper) \\ ISBN 978-0-472-12774-0 (ebook) \\ ISBN 978-0-472-90170-8 (open access)
}

The text of this book is licensed under a Creative Commons Attribution-NonCommercial-NoDerivatives 4.0 International License: https://creativecommons.org/licenses/by-nc-nd/4.0/ 
To my Gurus, eastern and western 



\section{CONTENTS}

\section{PART I: THE PAṆINIAN TRADITION}

I Principles of Historical Investigation 3

II Pāninian Theory of Homogeneity 7

III Kātyāyana's Theory of Ǎkrti-grahaña

IV Patañjali's Proposal of Prayatna-bheda 33

V A Non-traditional Approach 39

VI Back to Pāninini 47

VII Problems in Vākyāparisamāpti $\quad 61$

VIII Restrictions on Homogeneous-Representation 71

IX Vyāḍi on Homogeneous-Representation $\quad 79$

PART II: NON-PAṆINIAN TRADITIONS

X Prātiśākhyas on savarṇa $\quad 85$

XI Sikșās on savarṇa 103

XII Non-Pāninian Grammars on savarṇa $\quad 109$

$\begin{array}{ll}\text { XIII A Historical Overview } & 127\end{array}$

Appendix A: The Scope of Savarna-grahana

$\begin{array}{ll}\text { Notes } & 151\end{array}$

$\begin{array}{ll}\text { Bibliography } & 209\end{array}$ 

There are few problems indeed connected with Pānini that have been solved as yet in such a way as to make fresh investigations or additional support superfluous.

PAUL THIEME 



\section{PREFACE}

For the last few years, I have been interested in the concept of homogeneity (sāvarnya) in the Pāninian and nonPāninian traditions of Sanskrit grammar. In 1972, I published "Păninian Procedure of Taparakarana: A Historical Investigation," in Zeitschrift für vergleichende Sprachforschung, Band 86 . In this article, I had touched upon some aspects of the notion of homogeneity, but that was not the focus of the article. Afterwards, I continued my researches in the evolution of this notion in Pāninian and non-Pāninian traditions of Indian grammar. This has given me an opportunity to go through each text carefully, and see how the notion of homogeneity is defined and implemented in different ways. I have tried to be historical, not in the sense of arriving at a definite chronology of various texts, but in the sense of attempting to find the most natural interpretation of the texts as far as possible. After having studied different systems individually, I have tried to present the possible evolution of this concept.

To some of the readers it may appear that I could have presented this material in a more condensed form. However, after having taught Pānini in the West for some years, I have realized the need for being more explanatory. The traditional Indian pundits remember the whole rule, if only the first word is mentioned. That is, however, not the case in the West. Except for a few really good scholars, reading a work on grammar is still very difficult for most Westerners. The arguments are involved. The traditional writers take many things for granted. In order to make such texts intelligible to non-traditional readers, it is very necessary to provide the background material with as much clarity as possible. I have tried my writing on my advanced graduate students, and have attempted to find out exactly what kind of "explanation" they really need, in order to understand the arguments clearly. Coming from India, and having studied grammar traditionally, I used to take too much for granted. But thanks to my Western students, I have had the opportunity 
to come down to the earth, and discuss many points in detail. Therefore, I have striven to make my exposition as "readable" as possible, and have purposefully refrained from "unreadable condensation." I hope it serves its purpose.

I thank Mr. Jame Bare with whom I have discussed most of the material presented here. Having a student like him was certainly more than pleasure to me. He often raised more questions than I could find answers for. It may be mentioned that his $\mathrm{Ph}$. D. dissertation "Phonetics and Phonology in Pānini, " just submitted to the Department of Linguistics, the University of Michigan, is, in many respects, a continuation of the same line of research, and contains a good deal of discussion of homogeneous-representation. I have continued my own research in this field, after the completion of this book, and the results of that research are gradually being published in the form of independent articles. [Ref. "The Scope of Homogeneous-Representation in Pannini, " appearing in the Annals of Oriental Research, University of Madras; "Phonetics of /V/ in Pānini," appearing in the Annals of the Bhandarkar Oriental Research Institute, Poona; "Phonetics of short /a/ in Sanskrit," appearing in the Indo-Iranian Journal; and "New Material on the KautsaVyākarana, " appearing in the Journal of the Oriental Institute, Baroda. ]

I am also thankful to my friend and colleague Dr. Peter Hook for having gone through some portions of this work, and for insisting that I should explain more, rather than condense the arguments. I thank Prof. S. D. Joshi, Poona, and Prof. George Cardona, Philadelphia, whom I occasionally consulted. Prof. Cardona also helped me with some of the most rare books from his personal collection. I am grateful to Prof. Alton Becker, Director, Center for South and Southeast Asian Studies, University of Michigan, for providing me a research grant to visit India during the summer of 1974. I am also indebted to Prof. R. N. Dandekar, Secretary, Bhandarkar Oriental Research Institute, Poona, and to Dr. Trivikram Dharmadhikari, Secretary, Vaidika Samśodhana Mandala, Poona, for allowing me to use their rich manuscript collections, and obtaining microfilms of 
the necessary materials. I must express my gratitude to Prof. K. V. Abhyankar, Poona, for letting me use copies of some of the unpublished manuscripts in his possession. Finally, I thank the Publications Committee, CSSEAS, University of Michigan, for accepting this work for publication.

\section{Madhav Deshpande Ann Arbor \\ 29 September 1975}

Note: Due to the technical problems in underlining dotted Sanskrit letters, they have been left without the underline, while other letters in a word have been underlined. Since single dotted letters could not be underlined, no single letters have been underlined, but they have been put in between vertical slashes, e.g. /a/. This does not, in this book, have the normal linguistic significance of "a phoneme," but just refers to that particular Sanskrit sound. The same convention has been followed for the short-forms in Pānini's grammar, e.g. /a $-\mathrm{N} /$. 

PART ONE

THE PANNINIAN TRADITION 



\section{CHAPTER 1}

\section{PRINCIPLES OF HISTORICAL INVESTIGATION}

1.1. Grammatical procedures in Pānini's grammar have undergone a variety of interpretations at the hands of Kātyāyana, Patañjali and their followers. At each step in the tradition we encounter conflicts between the older grammarians (prācina) and the neo-grammarians (navya). These are relative terms and their referents keep on changing with time. The chief criterion of validity in the Pāninian tradition is that every explanation must be ultimately in consonance with Patañjali's Mahäbhäsya. Franz Kielhorn explains this principle:
Where there is a difference of opinion between Pāṇini and Kātyāyana, or between Kātyāyana and Patañjali, or between all the three, the native grammarians attach a higher value to the views of Kātyāyana to those of Pānini, and a higher value again to those of Patañjali to those either of Kātyāyana or Pānini. That such should be the case is not unnatural. ${ }^{1}$

The well known traditional maxim of the Pāninians says: yathottaram munīnām prāmānyam "The later the sage, the greater his authority." The grammarians belonging to a later period in history are bound to have more information. They possess knowledge of the earlier grammars and also knowledge of the linguistic changes which took place later on.

1.2. However, this principle is unhistorical from a different point of view. The original meaning of the rules of an ancient grammar is gradually lost under the weight and supposed authority of later interpretations. S. K Belvalkar succinctly points out this element of unhistoricity: 
They (the more orthodox grammarians) accordingly tried to invent new maxims of interpretation, tending to show, after a very diligent analysis of the works of the three great sages, that such defects as Chandragomin and others tried to find in the Pāninian grammar were in it already implicitly provided for. This procedure was no doubt unhistorical, but so was that of Kātyāyana or of Patañjali. ${ }^{2}$

While studying the works of the ancient Indian grammarians, a modern scholar has to take care that he is not himself trying to impose any unhistorical interpretation on these works.

1.3. In the course of the historical investigation into the tradition of Indian grammarians, we shall follow a principle which is laid down by Patañjali in his oft-quoted statement: siddhaty evam, apāniniyam tu bhavati "The correct result is established thus, but the method becomes un-Pāninian." In this statement, Patañjali draws a line of demarkation between notions of theoretical or applicational effectiveness of an interpretation and its historical validity or its conformity with Pānini's intentions. With this distinction, it is possible to make a fourfold system of classifying various interpretations in the Pāninian tradition.

[A] siddhyaty evam, pāninīyam ca bhavati: "The correct result is established thus, and the procedure is also Pāninian."

[B] Siddhyaty evam, apāninīyam tu bhavati: "The correct result is established thus, and yet the procedure becomes un-Pāninian."

[C] naivam siddhyati, pāninīyam tu bhavati: "The correct result is not established thus, and yet the procedure is Pāninian."

[D] naivam siddhyati, apāniniyam ca bhavati: "This way the correct result is not established, nor is the procedure Pāninian."

The types [A], [B] and [D] are quite clear, but [C] needs 
some clarification. This is usually the reason why Kātyāyana feels like proposing changes, additions etc. in Pānini's rules. In many cases, Kātyāyana believes, with ample justification, that a certain formulation of Pänini is bound to lead to some incorrect results. ${ }^{3}$

1.4. The two aspects of each of these classifications are not contradictory to each other, but they are significantly different. The aim of a historian of the Pāninian system is not to prove Pānini's grammar to be absolutely perfect, complete and free of errors. His function is to see how Pānini stands in his own right. If an ancient king lost a battle, no historian can make him win that lost battle. Similarly a historian should not refrain from recording inconsistencies and inadequacies in Pānini's grammar. It is the hard duty of a historian to detach later interpretations from Pānini. At the same time, he must look at different successive interpretations from the point of the historical development of the grammatical system. An un-Päninian interpretation could very well be a significant step in the development of grammatical theory and it must be given the credit that it deserves. Paul Thieme, whose work on Pānini is perhaps the best example of this historical approach, clarifies the methodology of historical research:

In the end, we have to return to Pāninin's formulations themselves, to compare his work, so to speak, with its own method, and to wring evidence from its weaknesses, which will betray something of its historical limitation: the merciless eye of the historian will not heed the beauty of the edifice in its entirety, but will be intent on looking for unassimilated elements which disturb its harmony, for flaws that might be due to the author being influenced by older sources, or not yet having reached certain stages of development.

1.5. In studying the theory of homogeneity (savarna) and its historical development, we shall not limit ourselves to 
the Pāninian tradition alone, but will undertake a thorough investigation of the entire range of the grammatical and phonetic science in India. We will first study this conception in the Pāninian tradition, and then pass on to the Prätiśākhyas, Śikșās and post-Pāninian grammatical systems. We shall study not only the definitions of homogeneity in these systems, but in each case, we must also study its implementation in those respective systems. With identical definitions, we do find quite different implementation of this conception, and this involves different kinds of historical relationships among various systems. 


\section{CHAPTER II}

\section{PĀNINIAN THEORY OF HOMOGENEITY}

2. 1. Pānini's grammar is headed by the well known fourteen Siva-suitras, the rules which are traditionally believed to have been given to Pänini by the Lord Siva. Most of the modern scholars now believe in Pānini's authorship of these rules and their genetic relationship with the formation of his grammar. 5 There rules are as follows:
1) $/ \mathrm{a} / \mathrm{i} / / \mathrm{u} / \mathrm{N} /$
2) $/ \mathrm{r} / / \mathrm{l} / \mathrm{K} /$
3) $/ \mathrm{e} / \mathrm{o} / \mathrm{N} /$
4) $/ \mathrm{ai} / \mathrm{au} / \mathrm{C} /$
5) $/ \mathrm{h}(\mathrm{a}) / / \mathrm{y}(\mathrm{a}) / / \mathrm{v}(\mathrm{a}) / / \mathrm{r}(\mathrm{a}) / / \mathrm{T} /$
6) $/ \mathrm{I}(\mathrm{a}) / / \mathrm{N} /$
7) $/ \tilde{\mathrm{n}}(\mathrm{a}) / / \mathrm{m}(\mathrm{a}) / / \dot{\mathrm{n}}(\mathrm{a}) / / \mathrm{n}(\mathrm{a}) / / \mathrm{n}(\mathrm{a}) / / \mathrm{M} /$
8) $/ \mathrm{jh}(\mathrm{a}) / / \mathrm{bh}(\mathrm{a}) / / \tilde{\mathrm{N}} /$
9) $/ \operatorname{gh}(\mathrm{a}) / / \mathrm{dh}(\mathrm{a}) / / \mathrm{dh}(\mathrm{a}) / / \mathrm{s} /$
10) $/ \mathrm{j}(\mathrm{a}) / / \mathrm{b}(\mathrm{a}) / / \mathrm{g}(\mathrm{a}) / / \mathrm{d}(\mathrm{a}) / / \mathrm{d}(\mathrm{a}) / / \hat{\mathrm{s}} /$
11) $/ \mathrm{kh}(\mathrm{a}) / / \mathrm{ph}(\mathrm{a}) / / \operatorname{ch}(\mathrm{a}) / / \operatorname{th}(\mathrm{a}) / / \operatorname{th}(\mathrm{a}) / / \mathrm{c}(\mathrm{a}) /-$ $/ \mathrm{t}(\mathrm{a}) / \mathrm{t}(\mathrm{a}) / / \mathrm{V} /$
12) $/ \mathrm{k}(\mathrm{a}) / / \mathrm{p}(\mathrm{a}) / / \mathrm{Y} /$
13) $/ \mathrm{s}(\mathrm{a}) / / \mathrm{s}(\mathrm{a}) / / \mathrm{s}(\mathrm{a}) / / \mathrm{R} /$
14) $/ \mathrm{h}(\mathrm{a}) / / \mathrm{L} /$.

These serve as a fundamental reference catalogue of certain sounds, arranged in a particular order conducive to the proper and concise formulation of the grammatical rules. Its purpose 
is not to give an inventory of all Sanskrit sounds, nor to teach correct pronounciation, but purely to facilitate concise formulation of rules. 6

2.2. The rule P.1.3.3 (hal-antyam), in its final interpretation, says: "[In the instruction], a final consonant [is termed it]," and the rule P.1.3.9 (tasya lopah) says: "There is deletion of that [which is termed it]. "Thus, all consonants occurring at the end of the Siva-sutras are termed it. The other term for it is anubandha. An it sound is a metalinguistic marker attached to a grammatical element. These markers will be given in capital letters and are unconditionally deleted. Though they are deleted and never appear in the object language, their functional significance still continues to operate. The rule P.1.1.71 (ādir antyena sahetā) says: "The initial [sound of a group] together with a final it [denotes the intervening members and itself] ." Applying this rule to the Siva-sutras, we can formulate shortforms (pratyāhāra) such as $/ \mathrm{a}-\mathrm{K} /, / \mathrm{i}-\mathrm{K} /$ etc. The shortform a-K/, for instance, stands for all sounds from $/ a /$ to $/ K /$, excluding the markers. Thus $/ \mathrm{a}-\mathrm{K} /$ stands for $/ \mathrm{a} / \mathrm{h} / \mathrm{i} / \mathrm{k}$ $/ \mathrm{u} /, / \mathrm{r} /$ and $/ \mathrm{l} / .7$

2.3. Then comes the notion of savarna "homogeneous sound." This term is sometimes rendered as "homorganic sounds," but that should be a more appropriate translation of the term sasthāna. The notion of savarna involves things in addition to the organs. Paul Thieme believes that the term savarna was borrowed by Pānini from some ancient Śikșā text, 8 while Burnell holds that Pānini took over this term from the ancient Aindra grammar and redefined it. 9 Whatever be its source, Pănini offers us a definition. The rule P.1.1.9 (tulyāsya -prayatham savarnam), in its traditional interpretation, means: "[A sound having in common with another sound a] similar internal effort [at a point] in the mouth [is termed] homogeneous [with respect to the other sound] ." As we shall see, this is what the rule must mean.

2.4. Kātyāyana found the wording of this rule to be unsatis factory. Following the usage of his times, Kātyāyana interpreted the term ãsya-prayatna to stand just for internal effort. 
Then he objected that such a definition would make two sounds homogeneous, if only they had the same internal effort, despite the difference in their points of articulation. 10 This is undesirable, since this would make the sounds $/ \mathrm{j} /$, $/ \mathrm{b} /, / \mathrm{g} /, / \mathrm{d} /$ and $/ \mathrm{d} /$ homogeneous with each other. He answered this objection by reformulating the rule:11 "The correct result is, however, established by [defining] a homogeneous sound [as the one which shares with another sound] the same point of articulation (desa) and [the same]

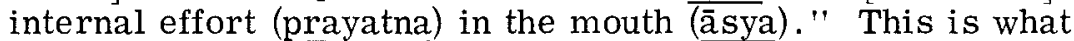
Pănini ought to teach and probably intended to teach.

Instead of accepting Kātyāyana's formulation, Patañjali reinterprets Pānini's rule to get at the same meaning. The word āsya normally means "mouth, "but Patañali explains it to be a taddhita-formation: asye bhavam $[\bar{a}$ sya + yaT $]$ "that which lies in the mouth," i.e. the point of articulation and internal effort. But the latter has been already mentioned by Pānini by the word prayatna. Thus finally the word āsya stands for "point of articulation" and prayatna stands for "internal effort."12 These are the two conditions for homogeneity.

2.5. Though we know what the rule ought to teach, the historical situation still remains unclear. In the Siksās and the Prātisaakhyas, the term āsya-prayatna stands only for internal effort. ${ }^{13}$ Breloer handled this term in the same way. ${ }^{4}$ In his early work, Paul Thieme believed that "Pānini's terminology is yet less developed. His expressions āsya -prayatna and mukha-nāsikā -vacana seem to betray that he did know the doctrine of sthāna and karana, which is familiar to the Prātiśākhyas. "15 However, Pānnini, who uses terms like mūrdhanya "cacuminal, retroflex" (P. 8.3.55) and osthya "labial" (P.7.1.101), could not have been unfamiliar with points of articulation. Yet we may agree with Thieme's following statement: "Auch sthäna wird von Pänini nicht in dem technischen Sinn 'Artikulationsstelle' vervendet, sondern heisst ein fach 'Platz, Stelle.' "16 Later on Thieme gave an explanation of ãsya-prayatna, which seems more probable: 


\begin{abstract}
Paninis Fassung der Definition lässt vermuten, dass er den Ausdruck prayatna noch nicht in dem späteren Sinne von 'Artikulationsweise' (sprșța, issat-sprsțta, vivrta usw.) gebrauchte, sondern in einem weiteren, so dass er auch die Artikulationsstelle ein begriff (der āsya -prayatna von $\underline{\mathrm{k}}$ würde demnach kantha-sprsța, der von p ostha-sprsta gewesen sein unsw.). Diese Annahme liegt um so näher, als Pāninis Sprachgebrauch auch sonst mit der phonetischen Terminologie der Prātisaākhya nicht in Einklang zu stehen scheint. 17
\end{abstract}

However, this involves some assumptions about the meaning of the term prayatna being different in Pänini. This is doubtful, since he uses the term again in P. 8.3.18 (vyor laghu -prayatnatarah śākatāyanasya), which has its parallels in the Prātišākhyas. [Whitney, APr, p. 83.] Actually, there is perhaps even an easier explanation of Pānini's āsyaprayatna. We could interpret the word a sya "mouth" as a general term covering all points on the vocal tract. This is evident from his parallel usage of mukha in P.1.1.8 (mukhanasikā-vacano' -nunāsikah). No anunāsika "nasal" sound is produced in the whole of the mouth, but it uses some point of articulation along with nāsikā "nose." For such a general conception of points on the vocal tract, Pänini used the general terms mukha and āsya.

In Sec. 11.7, we shall see that the term āsya-prayatna had a different meaning in the pre-Kătyāyana times. It included not only the internal effort, but also points on the vocal tract. Paninini was not alone in this usage and there were ancient Siksāa-texts with the same usage. This will help us revise Thieme's oft-repeated notion that P.1.1.9 (tulyāsya-prayatnam savarnam) is concise but not precise, and that the vārttika on this rule, i.e. siddham tv äsye tulya -deśa-prayatnam savarnam, alone is both concise and precise. [Thieme (1935), p. 93.]

By the time of Kātyāyana, the term āsya-prayatna became restricted to internal effort alone. This restricted notion is seen in the Vājasaneyi Prātiśākhya 1.43 (samānasthāna-karanā syaprayatnah savarnah). This created a 
problem for Kātyāyana and, therefore, he reformulated P.1.1.9 to fit the terminology of his days. Patañjali's interpretation of ãsya as āsye bhavam is only partially correct, because he says that âsya in this extended meaning stands for both sthāna "point of articulation" and karana "internal effort" [MB, Vol. I. Sec. I. p. 155] . [The term karana here does not stand for "articulator" or "active organ," see: Sec. 10.5.5.] If that were the case, then P.1.1.9 would be mentioning the internal effort twice. Actually Kaiyața and Nāgeśa do realize this problem, but somehow try to explain it away. [MB-P, and MB-P-U, Vol. I Sec. I. p. 155.] From a historical perspective, thus, Pănini was concise and precise in his definition, and does not stand in need of any reformulation or reinterpretation.

2.6. Thus, two sounds are homogeneous with each other, if they share the same points of articulation and internal effort. Thieme points out the relation of the term savarna with the term varna in its abstract sense. 18 Patañjali clarifies that the notion of savarna is based on difference (bheda) between sounds. He says that if the term "homogeneous" were to apply to those sounds alone, which have all identical features, then the designation would be useless. 19 Thus, the homogeneous sounds must agree with respect to two features, but may differ in other respects, i.e. the external efforts, quantity, nasality and pitch. Patañjali says that the term âsya also qualifies the term prayatna, thus excluding those efforts which lie, in some sense, outside the mouth (āsyād bāhyāḥ) . 20

2. 7. In Pānini's grammar, nasality does not affect homogeneity of sounds. But this exclusion of nāsikā "nose" from the conditions of homogeneity poses some problems. Nägeśa has a long argument on the status of nāsikā "nose." Does it fall within āsya "mouth?" Is it a point of articulation or an internal effort or an articulator? According to the Pāniniya -Sikșā, nāsikā "nose" is a point of articulation. Nāgeśa says that in P.1.1.8 (mukha -nāsikā -vacano' nunāsikah), Pānini mentions nāsikā along with mukha "mouth." Therefore, for the purpose of grammatical considerations, nāsikā is excluded from mukha. Since the words mukha and āsya are 
synonyms, the same applies to āsya. 21 Whether this reasoning is true or false, the conclusion is certainly right. A conclusive proof that nasality does not affect homogeneity in Pānini is offered by the fact that he includes semi-vowels in his procedure of savarna-grahana "representation of homogeneous sounds" [P.1.1.6 $\overline{9}]$. This is only to enable them to cover their nasal counterparts.

2. 8. There is also another important doctrine concerning homogeneity which must be mentioned here. This is the doctrine of sarva-sthāna-sāmya "identity with respect to all points of articulation. "If a sound has two points of articulation, say $x$ and $y$, then it can be homogeneous only with that sound which has $\underline{x}$ and $\underline{y}$ as its points of articulation. It cannot be homogeneous with a sound that has only $\underline{x}$, or only $\underline{y}$, or $\underline{x}$ and $\underline{z}$ as its points of articulation. Though, nāsikā "nose" is considered to be a point of articulation by the Pāninians, it is not taken into account. According to the later Pāninian tradition, $/ \mathrm{v} /$ and /1/ are both dental (dantya), but $/ \mathrm{v} /$ is also labial (osțya). Thus they cannot be homogeneous. Actually, there is a greater chance of $/ v /$ being only oșțhya "labial" for Pāninini, Kātyāyana and Patañjali, rather than being dantyoșthya "labio-dental" as believed by the Kăsika $-v r t t i$ and the later tradition. [For details, see my article "Phonetics of $\underline{v}$ in Paninini," appearing in the Annals of the Bhandarkar Oriental Research Institute. ] Similarly, the sound /ai is both kanthya "produced in throat" and tālavya "palatal." The sound Tau/is both produced in throat and labial (kanthausthya). Though they share one common point of articulation, they differ in the other and hence they are not homogeneous. Though this principle is not explicitly stated by Pạnini, it can be deduced from his rules.

2.9. With this background, let us take a brief survey of the phonetic categories adopted by the Pāninian tradition. Since Pänini's rules do not contain elaborate phonetic details, we have to depend on the traditional account, and then examine it critically. According to the points of articulation, sounds are classified as sprsța "with contact of the articulator and the point of articulation, "Ișat-sprșța "with slight contact," 
vivrta "open, without contact" and samvrta "closed." The category of vivrta "open" was later subdivided by Patañjali into Isad-vivrta "slightly open," vivrta "open, "vivrta-tara "more open" and vivrta-tama "most open." This is an important subclassification and it played a great role in later dialectic. Here we need not go into the details of the external efforts and other minor points, since our discussion does not concern them.

2.10. For Pānini, the sounds termed ūṣman, i.e. $/ \bar{s} /, / \mathrm{s} /$, $/ \mathrm{s} /$ and $/ \mathrm{h} /$, and vowels have the same internal effort. They are all vivrta "open." Thus, there is a possibility of some vowels being homogeneous with certain ūsmans. To counter such a possibility, Pānini formulated P.1.1.10 (näjjhalau) which says that the sounds denoted by the shortforms /a-C/ and /ha-L/ are not mutually homogeneous. This rule actually intends to deny homogeneity of all vowels and consonants with each other. However, its interpretation poses certain grave problems, which will be considered later in detail. Since Pānini's definition was clearly couched in featural terms, it created another problem for him. The short /a/ was a samvrta "closed" sound, but long and extra-long varieties were vivrta "open." In order to get their homogeneity, Pannini ruled that the short $/ \mathrm{a} /$, within the grammatical system, is an open sound. The final rule of his grammar, P.8.4.68 ( $\underline{\mathrm{a}} \mathrm{a})$ ), reinstates the closed /a/ sound in the object language. K. C. Chattopadhyaya (1974) holds a different opinion on this point. He thinks that Pānini had an open (vivrta) short /a/, which was natually homogeneous with $\overline{\bar{a} / \text { and }} / \bar{a} 3 /$. In post Pāninian times, under the influence of Dravidian languages, the short $/ \mathrm{a} /$ became a closed sound. To account for this short $/ a /$, later Päninians inserted P. 8.4.68 ( a a ). He tries to show that most of the Prātisâkhyyas and $\overline{\text { Sik }}$ sãs support his argument. I disagree with Chattopadhyaya, and have dealt with his argument in my article "Phonetics of Short A in Sanskrit," appearing in the Indo-Iranian Journal.

After thus defining the term savarna, Pānini introduces a procedure, which is well known as savarna -grahana "representation of homogeneous sounds." The rule P. 1.1 .69 
(an-udit savarnasya cāpratyayah) says: "A sound [which is denoted by the short-form] /a-N/ [with $/ \mathrm{N} /$ in the Siva-sütra /l(a) $\mathrm{N} /$ ] , or a sound with the marker /U/ stands for its homogeneous sounds and for itself, unless it is an affix." This is widely used in the rules of Pānini. Its details will be discussed later on.

2.11. Apart from P.1.1.9 (tulyã sya -prayatnam savarnam) and P.1.1.69 (an-udit savarnasya cāpratyayah), Pānini uses the term savarna in eight rules. They are as follows:

1) P.1.1.58 (na padānta-dvirvacana-vare-yalopasvara-savarnānusvāra -dírgha-jaśs-car -vidhisus)

2) P.6.1.101 (akah savarne dirghah)

3) P.6.1.102 (prathamayoh pürva-savarnah)

4) P.6.1.127 (iko'savarne sākalyasya hrasvaś ca)

5) P.6.4.74 (â̄hyāsasyā savarne)

6) P.7.1.39 (supām suluk pūrva-savarnāccheyādādyāyāajālah)

7) P.8.4.58 (anusvärasya yayi para-savarnah)

8) P.8.4.65 (jharo jhari savarne)

In some of these cases, the term savarna or the compound with that term continues into the following rules. The term is mostly used in the context of vowels, semi-vowels and stops, except in a few cases. For instance, in the rule P. 8. 4.65 (jharo jhari savarne), it is also used with respect to $/ \hat{\mathbf{s}} /, / \mathrm{s} /$ and $/ \mathrm{s} /$. These sounds have no homogeneous sounds other than themselves.

Another point that needs to be noted is that P.1.1.69 does not mean that all the sounds incorporated in the shortform /a $-\mathrm{N} /$ must have homogeneous sounds other than themselves. The sounds $/ \mathrm{h} /$ and $/ \mathrm{r} /$ have no homogeneous sounds other than themselves. The rule says that the $/ \mathrm{a}-\mathrm{N} /$ sounds stand for their homogeneous sounds, if they have any. 22

Kunhan Raja (1967) has raised the question of the limit of $/ \mathrm{a}-\mathrm{N} / \mathrm{in} \mathrm{P} .1 .1 .69$. He argues that $/ \mathrm{a}-\mathrm{N} / \mathrm{even}$ in this rule is limited only to the first Siva-suitra. In my article "The Scope of Homogeneous-Representation in Pänini" 
[appearing in the Silver Jubilee Volume of the Annals of Oriental Research, University of Madras], I have extensively dealt with this question. The conclusion of this article is that /a-N/ in P.1.1.69 certainly extends to $/ \mathrm{N} /$ in the Siva-sūtra /1(a) -N/; however, no practical purpose is served by the inclusion of semi-vowels in P.1.1.69. The theoretical purpose is quite obvious. [Also see Appendix A.]

2.12. To sum up, we might say that the procedure of savarna -grahana "homogeneous-representation" is a procedure built of five steps discussed earlier. There are many differences of opinion concerning the exact interpretation of these five stages. At times we have proposals for additional postulates which make some of these stages unnecessary. Some of the differences are rooted in the differences between alternative priciples of interpretation.

2.13. Here it is necessary to see how a difference in theoretical axioms affects the final output of a grammar. Let us consider two hypothetical situations.

Situation [A]: Suppose that we have a rule $R_{1}$ which contains the term $\underline{\text { a. }}$. Is it possible to apply the rule $R_{1}$ to the term a in the same rule? Let us say that the rule $R_{1}$ is as follows: "a stands for $\underline{a}, \underline{b}$ and $\underline{c}$." If the rule $R_{1}$ applies to itself, then the term a in the rule itself could stand for $\underline{a}, \underline{b}$ and $\underline{c}$. Thus, the rule could be rewritten as: "aㅡ, $\underline{b}$ and $\underline{c}$ stand for $\underline{a}$, $\underline{b}$ and $\underline{c} . "$ This could mean that each one of them could stand for all of them. If the rule does not apply to itself, then a stands for $\underline{a}, \underline{b}$ and $\underline{c} ; \underline{b}$ stands for $\underline{b}$, and $\underline{c}$ stands for $\underline{c}$.

Situation [B]: If there are two rules, $R_{1}$ and $R_{2}$, such that $R_{2}$ presupposes $R_{1}$, is it possible that $R_{2}$ could apply to $R_{1}$ or a part of it? This gives us two alternatives. Either $\mathbf{R}_{2}$ may apply to $\mathrm{R}_{1}$, or it may not apply.

By combining the alternatives in [A] with those in [B], we could get several possible ways. Most of these alternatives 
16

are reflected some way or the other in the discussions in the Pāninian tradition, along with certain other postulates. 


\section{CHAPTER III}

\section{KĀTYĀYANA'S THEORY OF $\underline{\text { AKRTI-GRAHANA }}$}

3.1. As an alternative to Pănini's procedure of savarnagrahana "representation of homogeneous sounds, " Kātyāyana proposes the philosophical procedure of âkrti-grahana "mention of a sound-universal." He says: "T The desired morphophonemic procedure] is established by understanding the sound-universal [as being mentioned in the Śiva-suttras and elsewhere] ," and Patañjali explains this as: "[In the Śiva-sutras and elsewhere], the universal of the sound /a/ is taught and it will cover the whole class of /a/ sounds [including long and extra-long varieties]. Similarly are [ taught] the universals of the sounds $/ \mathrm{i} /$ and $/ \mathrm{u} / . " 23$ In this view, the particular sounds uttered in the Siva-sütras could be understood as tokens standing for the types or sound universals which cover all the particular sounds belonging to that type or sharing that universal. This is like the sentence: "A brahmin should not be killed." The statement does not mean that, leaving aside one brahmin, the rest of them could be killed, but rather that anybody who belongs to the class of brahmins or shares the universal brahmin-ness should not be killed. Thus what is intended is not a single brahmin, but the universal brahmin-ness. 24 Kātyãyana adds that this notion of a universal extends to consonants also. 25 Just as the universal of $/ a /$ covers $/ \bar{a} /$, similarly the universal of $/ y /$ covers $/ \bar{y} /$. However, the universal of $/ \mathrm{k} /$ does not cover $/ \mathrm{kh} /$ and other members of that varga. Kātyāyana clearly points out that this universalmention is not an explanation of Pänini's homogeneous representation, but an alternative to it. If one is adopted, the other is almost unnecessary. Kātyāyana says: "In P.1.1.69, the $/ \mathrm{a}-\mathrm{N} / \mathrm{sound}$ need not be mentioned, since the sound universais are mentioned [in the Śiva-sütras] ."26 Thus, in the theory of universal-mention, no homogeneous representation is necessary for vowels and semi-vowels, 
but it is still necessary for the homorganic groups of stops (varga). Thus, Kātyäyana is proposing a partial modification of Pānini's system.

3.2. The distinction between these two procedures needs to be clearly understood. According to the theory of universal mention, the sounds listed in the Siva-sūtras are a type listing, without P.1.1.69. On the other hand, Pānini lists individual sounds and then states P.1.1.69 whereby they could stand for their homogeneous sounds. 27 Recently, Scharfe 28 and Ghatage ${ }^{29}$ seem to have fused one into the other. Biardeau 30 discusses savarna in the context of ăkrti, but leaves an impression that she does not consider them to be different alternatives. On the background of this, a clear differentiation of these two seems to be of vital importance. Kātyāyana is bringing a non-Pāninian notion into Pānini's grammar. This new notion of varnākrtî "sound-universal" is a philosophical interpretation of the old class-conception of varna, the real sound, where features of quantity, nasality and accent were non-distinctive for inclusion in a varna. Thus a -varna could cover $/ \bar{a} /$ and $/ \bar{a} 3 /$, the varna of $7 \mathrm{y} /$ could cover $/ \bar{y} /$. However, the varna of $/ \mathrm{k} /$ could not cover $/ \mathrm{kh} /$ and other homorganic stops. For this purpose, the notion of varga was used along with -varna. Pānini's expanded definition of savarna was a sophisticated attempt to cover both of the se older notions under a single generalization. Kătyāyana brought back the older notions in a new philosophical form. Thus his notion of äkrti worked for the older notion of varna, while he still retained Pānini's savarna-grahana to account for the older notion of varga. A detailed discussion of this older notion of varna is taken up later in the context of the Prātiśākhyas.

3.3. As it has been already explained, Kātyāyana's theory partially replaces Pānini's homogeneous-representation. The fact that this new theory does not belong to Pānini is realized by the traditional commentators. Bhattoji Dikșita says: "This view [ of universal-mention] is not intended by the author of the sutras, since he incorporates [ the term] /a-N/ [in P. 1.1.69]."31 He further states: "The author of the sütras does not formulate [his rules] after 
having seen the vārttikas [ of Kātyāyana] ."32 Nāgeśa and some of the later commentators on his works clearly bring out this historical development. 33 The commentary Cidasthimālā on Nāgeśa's Laghu-śabdendu-śekhara says that if we accept the rules related to the procedure of savarna -grahana, then there is no a kntri -grahana. 34

3.4. The theory of universal-mention needs to be subjected to a critical examination, both for its merits and drawbacks. Pānini clearly defined savarna in featural terms, but there is no clear definition of a sound-universal found anywhere in Kãtyāyana's vārttikas. Patañjali explains that the universal of /a/ is mentioned [in the Siva-sutras] and it will cover the whole family of $/ \mathrm{a} /$ sounds. 35 Bhartrhari, in his Mahābhāsya-dīpikā, sheds some light on this notion:

The desired [ coverage of many varieties] is established by universal-mention. In shortforms and in other rules, a universal is prescribed, and not an individual. Resorting to an individual [in order to mention a universal] is like this: It is thus advised to an inhabitant of the Nãrikela island: "This is a bull. You should not touch him with your feet." Though he is advised actually with respect to a young, black and skinny bull, still he does not touch even an old, tawny and fat bull. 36

Thus when one hears $/ a /$, he develops a notion of some generic features. When he hears $/ \bar{a} /$, he recognizes the same generic features in $/ \bar{a} /$. This is how a person identifies the same universal in different instances. This seems to be the import of Bhartrhari's explanation.

3.5. Since there is no clear definition of a universal, nor of any standard way of recognizing its presence, this notion certainly seems to be very impressionistic. We are not sure if the origin of this notion lies in phonetic considerations, or somewhere in the realm of realistic metaphysics. Perhaps this is an outcome of a combination of different influences. Kătyāyana himself uses frequently the grammatical terminology of the Prātiśākhyas, which was replaced by Pãnini with new terms. 
In this old terminology, we have a conception of varna which stands for "the real sound" or class of sounds which differ only in features like quantity, nasality and pitch. There also existed a conception of varga "group of homorganic stops" alongside with the class-conception of varna. Kätyāyana was obviously familiar with this conception. At the same time, early schools of Mīmāinsā were coming up in pre-Kātyāyana days. He was deeply interested in their philosophical speculations, and quoted their controversies in great detail. The two important names are those of Vyādi, who held Vyakti -väda "doctrine of individuals," and Vājapyāyana, who held the opposite doctrine of $\bar{A} k r t i-v \overline{a d a}$ "doctrine of universals." Most probably, under the influence of Vãjapyāyana's thoery of universals, Kātyāyana reinterpreted the old conception of varna and came up with the doctrine of varnākrti "sounduniversal." Even in this new philosophical form, the notion still remained very much impressionistic or conventional.

The system of Mīmāmsā considers sounds (varna) to be eternal, and these eternal sounds are manifested by physical sounds which are not eternal. However, the relation between non-eternal physical sounds and eternal linguistic sounds is not that between a universal and individuals which share that universal. The eternal sound is like an eternal individual. 37 The notion of sound-universals is found used in the system of Nyāya. This system believes that the sounds of a language are not eternal, their existence being limited by their production and disappearance. Yet we have a perception of identity each time we hear certain sounds: "It is the same /g/ sound, which I heard before." This perception of identity is due to the common universal shared by many instances. 38 Kaiyata's explanation of the sounduniversal $/ \mathrm{k} /$-ness is very similar to the Nyāya view. He says: "The universal $/ \mathrm{k} /$-ness etc. pertains to individual sounds or is manifested by specific instances of sounds.... The [sound] individuals are infinite and they are produced [in contrast to the eternal universals]. "39 It must be remembered, however, that Kātyāyana's notion belongs to a very ancient period of philosophy, and most of the systematic works in different philosophical schools are certainly postKātyāyana. 
3.6. The ambiguity concerning how many varieties a certain sound-universal can cover is reflected in several discussions in Kātyāyana's own vārttikas and in Patañjali's Mahābhāsya. In his introductory remarks on Pānini's grammar, Kātyāyana has raised questions as to the purposes of the Siva-suttra listings. One of the alleged purposes is the proper teaching of all the sounds in Sanskrit. 40 To this Kätyāyana presents an objection by saying that if this is the purpose, Pānini should list all the varieties of sounds differing in pitch, quantity and nasality. ${ }^{41} \mathrm{~A}$ reply to this objection is given by saying that the Siva-sütras are a list of sound-universals, which would naturally cover all these varieties. 42 Then comes an objection to this reply: "If [one says that] the desired [coverage of necessary varieties] is established by the mention of sound-universals, then a prohibition of [vowels that are possessed of ] constriction of mouth or other similar faults has to be laid down." 43 This objection amounts to saying that just as a sound-universal covers all the correct or unfaulty (suddha) instances, similarly it would also cover those instances which involve faults. A sound-universal is shared by correct as well as by incorrect instances, and there is no philosophical reason why a sound-universal could represent only the correct instances. Patañjali observes that if one accepts this doctrine of universal-mention, one may have to make an all out effort to reinstate the correct varieties of sounds. 44 The upholder of universal-mention suggests that these faulty varieties of sounds could be given metalinguistic functions, and could then replace the whole system of marker-sounds in Pāninian rules. 45 Patañjali says that this could be done, but then the procedure becomes un-Pāninian. 46 Even though it is easy to talk of constructing rules for reinstating the correct varieties, in actuality, it would be a very difficult task. Compared to the correct varieties, faults are too many to count. This is surely not an advisable procedure.

3. 7. Patañjali then continues the argument of the upholder of universal-mention. He asks as to where could these faulty varieties occur. They could not occur in augments (āgama), substitutes (vikāra), affixes (pratyaya), verb roots (dhātu) or nominal stems which are either derivable from the 
enlisted smaller items or which are directly listed by Pānini. Pānini taught all these items with correct pronounciation. The only items which are left are the nominal stems which are underivable and are not listed by Pannini. It is suggested that even these should be listed in order to teach their proper pronounciation. $47 \mathrm{~K}$. V. Abhyankar explains the purport of this suggestion:

This is the final conclusive solution to the difficulty raised above, viz. that if in the formation of words faulty utterances are made for signifying grammatical operations, those faults would remain in the words after their formation also. The author says here that the original crude bases of words are uttered faultless and thereafter in the process of formation, augments, substitutes, affixes and the like are also uttered faultless; as a consquence no occasion arises for formed words being attended with faulty utterances. 48

It is doubtful if it is a conclusive solution. It is quite clear that it is a suggestion for a complete listing of underived nominal stems, which does not exist in Pānini. Patañjali, in other contexts, makes it clear that such a listing of underived nominals involves prolixity (tad guru bhavati, see n. 47). Bhartrhari suggests that finally we have to rely on the usage of the natural speakers of Sanskrit (sista) to determine correctness of words, and the same reference is to be the authority in excluding these faulty varieties. 49 Thus the procedure of universal-mention finally involves too many assumptions.

3.8. There are many other problems which confront the upholder of universal-mention. According to Pạnini, the original root in the forms kalpate and klpta is vkrp. From this root, we first derive the forms karpate* and krpta*, and then $/ \mathrm{r} /$ and $/ \mathrm{r} /$ are replaced by $/ \mathrm{l} / \mathrm{and} / \mathrm{l} /$. For both the changes, there is only one rule, P.8.2.18 (krpo ro lah), which literally means: "/r/ of [the root] vr. is replaced by $/ 1 /$." The constitution of $/ \mathrm{r} /$ and $/ \mathrm{l} / \mathrm{is}$ such that they contain vocalic and consonantal elements fused together. Thus: 


$$
\begin{aligned}
& / \mathrm{r} / \text { is } \frac{1}{4} / \partial /+\frac{1}{2} / \mathbf{r} /+\frac{1}{4} / \partial / \text { and } \\
& / 1 / \text { is } \frac{1}{4} / \partial /+\frac{1}{2} / 1 /+\frac{1}{4} / \partial / .
\end{aligned}
$$

If parts of a composite sound are looked upon as independent sounds and could be represented by independent sounds, then there is no problem in the present case. The sound $/ \mathrm{r} /$ in the rule would stand for independent $/ \mathrm{r} /$, as well as for $/ \mathrm{r} /$ that forms a part of $/ \mathrm{r} /$. The same would apply to $/ 1 / .50$ But if the so-called parts of a composite sound have no independent reality and cannot be represented by independent sounds, then we may have to have a separate rule for substituting $/ \mathrm{r} /$ by $/ 1 / .51$

At this stage, Patañjali offers two solutions which would avoid formulation of an additional rule. The second solution runs as: "Or, rather, it should be understood that in both [the cases, i.e. rah and lah], only the class sound (sphota) is mentioned. Thus the sound heard as $/ \mathrm{r} /$ (ra-sruti) is replaced by a sound heard as /1/ (1a-sruti)." This passage has given rise to many interpretations in the context of the celebrated theory of sphota. However, we shall restrict ourselves only to those considerations which are pertinent in the context of the notion of sound-universals.

3.9. Bhartrhari explains the above argument as follows: "Or, the word sphota-mātra indicates that this is a universalmention... The purpose of universal-mention is that it covers both $/ \mathrm{r} /$ sounds, one which is independent and the one which forms part of $/ \mathrm{r} / . " 53$ Thus, the universal of sound $/ \mathrm{r} /$ covers, according to Bhartrhari, the sound $/ r /$ which forms part of $/ \mathrm{r} /$. Kaiyata expresses the same view. 54 Thus the rule says: "In the case of the root Vरrp, the universal of $/ r /$ is replaced by the universal of $/ 17.55$ Nägeśa, on the other hand, is not ready to accept a sound-universal which covers independent and dependent varieties. 56

3.10. Just as there is a consonantal element in $/ \mathrm{r} /$, similarly there is also a vocalic element which is called ac -bhakti "a split vowel." 57 Just as /a/ covers long and 
extra-long varieties by homogeneous-representation (p.1.1.69), similarly one may extend this coverage to the vocalic particles in $/ \mathrm{r} /$ and $/ 1 /$. This objection could also be raised in the theory of $u$ aiversal-mention. The universal of /a/might be said to cover these vocalic particles. 58 But Bhartrhari says that /a/ in no way can stand for these vocalic particles. He remarks: "This vocalic particle of quarter-mora quantity is not found anywhere else. There is no homogeneity. A part [ of a composite sound] does not have a phonetic effort and points of articulation, independent from those of the whole. This vocalic particle is also incapable of manifesting the sound-universal of /a/ etc." 59 Kaiyata points out that the perception of this vocalic particle is very indistinct and is not capable of manifesting any sound-universal. 60 Nāgeśa agrees with Kayata's judgement. 61

3.11. In Pānini's Śiva-sūtra: $r-\underline{r}-\underline{K}$, the sounds $/ r /$ and /1/ are listed separately. No two sounds directly listed in the Śiva-sütras are mutually homogeneous with the only exception of stops. A similar argument is offered by Bhattoji Diksita for $/ \mathrm{e} /$ and /o/ not being homogeneous with $/ \mathrm{ai} /$ and $/ \mathrm{au} / .62$ Kaiyata clearly says that $/ \mathrm{r} /$ and /1/ are not homogeneous with each other for Pänini, though they are so for Kātyāyana. 63 In the real usage, the sound $/ 1$ / occurs only in the forms of tê. This is noted by Patañali, all of whose other examples are pure fabrications. 64 Thus, Pănini did not need separate rules for guna and vr. changes of $/ 1 /$, since he took care of the only occurrence of $/ 1 /$, the root kㅏㅁ, by the above explained way.

Literally, P.1.1.51 (ur an ra-parah) says: "The /a $-\mathrm{N} /$ replacements of $/ \mathrm{r} /$ are immediately followed by $/ \mathrm{r} / . "$ Based on this rule is the notion of some modern authors that the guna for $/ \mathbf{r} /$ is $/ \mathbf{a r} /$, and its vrddhi is $/ \bar{a} \mathbf{r} /$. Actually for Pānini, the term guna applies only to $/ \mathrm{a} /$, $/ \mathrm{e} /$ and $/ \mathrm{o} /$, while the term vrddhi applies only to $/ \bar{a} /$, $/ \mathrm{ai} /$ and $/ \mathrm{au} /$. But $/ \mathrm{a} /$ and $7 \dot{\vec{a}} /$ which replace $/ \mathrm{r} / \mathrm{are}$ immediately followed by $/ \mathrm{r} / .65$ To derive kalpate, we start from karpate* and replace $/ \mathrm{r} /$ by $/ 1 /$. Thus there is no occasion for $/ 1 /$ being directly changed to /al/. Thieme is certainly right when he points out that there is no guna to $/ 1 /$ in Pānini's system. 66 
3.12. Kātyāyana proposes that $/ r /$ and $/ 1 /$ be considered mutually homogeneous. 67 These sounds actually have different points of articulation and they would not normally become homogeneous in Pānini's system. Kätyāyana imposes this homogeneity, for specific purposes. 68 If $/ \mathrm{r} /$ is homogeneous with $/ 1 /, / r /$ can stand for $/ 1 /$ also. Thus the rule P.1.1.51 (ur an ra-parah) would mean: "The /a-N/ sounds which replace $7 \mathrm{r} /$ and $/ 1 /$ are immediately followed by $/ \mathrm{r} /$." Patañjali sees this situation arising. $69 \mathrm{He}$ counters such a possibility by saying: "I shall rule that [ the /a-N/ substitutes of] $/ 1 /$ will be followed by $/ 1 /$. This provision has to be given. [This provision] would be prescriptive, if the term 'homogeneous' is not [applied to $/ 1 /$ with respect to $/ \mathbf{r} /]$. The same [provision] would help avoiding [ the possibility of the /a -N/ replacements of $/ 1 /$ being followed by] $/ \mathrm{r} /$, if [ the term 'homogeneous'] is applied [ to / $/$ with respect to $/ r /]$. "70 This is a very significant statement. Patañjali suggests here that if $/ \mathbf{r} /$ and $/ 1 /$ are not homogeneous, as in the view of Pānini, there is no fear of the /a $-\mathrm{N}$ / substitutes of / $/$ being followed by $/ \mathbf{r} /$. But then Pānini does not provide that they will be followed by / $/$ either. Such a proviso has to be made to account for the fictitious examples, or grammatical expressions involving $/ 1 /$.

\subsection{Now a question arises as to how to understand} Kātyāyana's statement on homogeneity of $/ \mathrm{r} /$ and $/ 1 /$, in the light of his doctrine of universal-mention. Kätyāyana does not give us any direction in this case. Patañjali is also silent. Coming down to Bhartrhari, we find the following explanation:

When we accept the statement that $/ \mathrm{r} /$ and $/ \mathbf{l} /$ are homogeneous, and also when P.1.1.69 is rejected due to universal-mention, then, despite the difference of the sound $[/ r /$ and $/ 1 /$ in $/ r /$ and $/ 1 /]$, they [i.e. $/ \mathbf{r} /$ and $/ 1 /]$ have the same universal, just as short and long [corresponding vowels have the same universal]. 71 
Bhattoji Diksita refuses to accept that $/ \mathbf{r} /$ and $/ 1 /$ have the same sound-universal. According to his view, $/ r /$ cannot cover $/ 1 /$ unless we make a special provision. 72 He suggests that we should take out the term /a $-\mathrm{N} /$ from P.1.1.69, following Kătyāyana, and put in $/ \mathrm{r} /$ in its place. Thus P.1.1.69 should be rewritten as $/ \mathrm{r} /$-udit savarnasya etc. ${ }^{73}$ This way $/ r /$ will cover $/ 1 /$. He also suggests that homogeneity hetween $/ \mathrm{r} /$ and $/ i /$ has to be optional, or otherwise it would create several other problems. 74

Nāgesa accepts a different doctrine. He thinks that Kātyāyana's statement imposes the same universal on $/ \mathrm{r} /$ and $/ 1 / .75$ Some of the commentaries on Nāgeśa's Laghusabdendu-sekhara try to show that the word savarna itself could be interpreted to mean "having the same universal" (sajätiya), since the word varna is sometimes synonymous with jāti in the sense of "caste." 76 In fact, Liebich does interpret the word savarna as: "von gleicher Kaste" [see n. 344] . Hari Diksita refers to poetic interchangeability of $/ \mathrm{r} /$ and $/ 1 /$ and says that for these reasons the sounds $/ \mathrm{r} /$ and $/ 1 /$ could have the same universal. 77 of course, Kätyãyana had a very specific purpose in prescribing their homogeneity, i. e. obtaining a general rule for guna and vrddhi of $/ 1 /$ being followed by $/ 1 /$. This seems to have been his only limited purpose. He needed this to explain usages with $/ 1 /$, which came about through incapability of proper pronounciation (asaktija) and imitation of such usages (anukarana) etc. No traditional grammarian ever clarified this limited purpose of this imposed homogeneity, except for the fact that Bhattoji Diksita thought it to be optional and not obligatory throughout the grammar.

3.14. There is another kind of ambiguity involved in the notion of universal-mention, which has been discussed at some length by some of the later commentators. They classify universals into pervading universals (vyäpaka-jăti) and pervaded universals (vyāpya -jāti). The universal of the sound /a/ of which Kâtyāyana and Patañjali speak covers the whole class of /a/ sounds (sarvam a-varna-kulam), and this is the pervading universal. However, there are also pervaded universals, such as the restricted /a/-ness, 
which covers only the short varieties. Similarly, we can have $/ \bar{a} /$-ness pervading only the long varieties, and $/ \bar{a} 3 /$-ness pervading only the extra-long varieties. 78 Thus, we have the following scheme of coverage:

$$
/ \mathrm{A} / \text {-ness }
$$

(pervading universal)

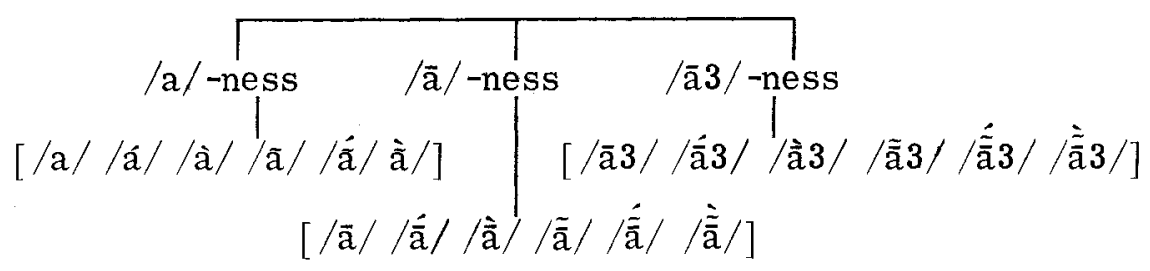

It has also been discussed whether the Siva-sütras contain the pervading universals or the pervaded universals. Each of these alternatives has a different implication. If the Siva-sūtras contain the pervading universals, then there is no need of the procedure of homogeneous-representation in those cases. But if they contain the pervaded universals, then we still need that procedure. Suffice it to say that Kātyāyana intended the first alternative.

3.15. As a merit of this theory of universal-mention, it should be pointed out that its acceptance helps us to get rid of the rule P.1.1.10 (nājjhalau). This rule intends to deny any possible homogeneity between vowels and consonants. In the theory of universal-mention, vowels and consonants have different universals and hence there is no scope of homogeneity or co-universality of any vowels with consonants. Thus, despite the fact that $/ \overline{\mathrm{a}} /$ and $/ \mathrm{h} /$ have the same internal effort and point of articulation, 79 they do have different universals, and hence there is no problem. This has been noticed by some of the commentaries on Nägeśa's Laghusabdendu-śekhara. 80 Another benefit could also be derived from this theory. Despite the difference of internal effort between $/ a /$ and $/ \bar{a} /$, they share the same universal, and hence we do not need anything like Pānini's pronounciation of /a/ as vivrta "open," within the system, and its reinstatement to samvrta "closed" by P. 8.4.68 (aㅡ a). As far as I 
know, no grammarian has noticed this point. As we shall see later, those grammatical traditions, which accepted the impressionalistic notion of varna and savarna, were never faced with this problem. Kătyāyana's notion of universal is equally based on such conventional impressionism, and he, therefore, did not have to face the problem that Pānini was faced with.

3.16. Pāninin's rule P.1.1.69 (an-udit savarnasya cāpratyayah) says: "The /a $-\mathrm{N} /$ sounds and the sounds marked with /U/ represent their homogeneous sounds along with themselves, if they are not affixes. "81 By this rule, the process of homogeneous-representation applies to vowels, semi-vowels and stops. In the view of universal-mention, however, a universal of $/ \mathrm{k} /$ cannot cover the homorganic stops. ${ }^{8}$ Kâtyāyana is aware of this short-coming and he only suggests removal of / a $-\mathrm{N} /$ sounds from homogeneous-representation. Thus he still retains homogeneous-representation for stops. This means, we would still need the rule: udit savarnasya. Since this rule contains the term savarna "homogeneous," we still need the definition of homogeneity (P.1.1.9), which still remains a general definition and covers even those sounds, which are already covered by universal-mention. Thus the procedure of universal-mention cannot function by itself, and needs assistance of homogeneous-representation. On the other hand, the latter can very well function by itself. The difficulty in accepting both the procedures simultaneously is that both of them presuppose opposite philosophical doctrines. Nāgeśa points out that P.1.1.69 is based on vyakti -văda "doctrine of individuals, "and on distinctiveness of pitch, nasality and quantity. 83 The principle of universal-mention, on the other hand, presupposes that a sound, by nature, stands for its universal, which naturally covers varieties differing in pitch, nasality and quantity. What is intended is a universal, and an individual is given simply because there is no other way of expressing the universal. 84

3.17. Even if we decide to follow universal-mention and omit /a-N/ from P.1.1.69, we still do not achieve simplicity of description. The condition apratyayah "non-affixal" 
in P.1.1.69 says that affixal sounds cannot stand for their homogeneous sounds. Nāgeśa points out that we still need this condition in universal-mention. 85 This is comparable to Kātyāyana's treatment of P.1.1.70 (taparas tat-kālasya) which says that a vowel followed by the marker $T \mathrm{~T} /$ stands only for homogeneous varieties of the same quantity. 86 Kătyāyana says that this rule operates even in universalmention. 87 Patanjali explains that a vowel without $/ \mathrm{T} /$ may cover all co-universal (sajātiya) varieties. To restrict this, wherever we need, to varieties of the same quantity, we must use the marker $/ \mathrm{T} / .88$ Nãgeśa realizes similarity between this argument and the restriction made by the condition apratyayah in P.1.1.69.89

3.18. Finally, we should investigate some of the subtle problems created by universal-mention, which can certainly be avoided by a proper interpretation of Pänini's savarnagrahana. In the final interpretation of P.1.1.69, only the /a-N / Sounds as they are listed in the Siva-sütras have the capacity of representing their homogeneous sounds. Thus, /a / can represent varieties of $/ \bar{a} /$ and $/ \bar{a} 3 /$, but $/ \bar{a} /$ cannot represent either $/ \mathrm{a} /$ or $/ \overline{\mathrm{a}} 3 / .90$ By P.1.1.70 (taparas tat-kālasya) a vowel followed by $/ \mathrm{T} /$ stands only for homogeneous sounds of the same quantity. Thus, in the case of /a $-\mathrm{N} /$ sounds, this mule becomes restrictive, while it becomes prescriptive for non $-/ \mathrm{a}-\mathrm{N} /$ sounds. 91

In universal-mention, in principle, any instance stands for its universal and that universal covers all couniversal varieties. Thus, the difference between $/ \mathrm{a}-\mathrm{N} /$ and and non $-\mathrm{a}-\mathrm{N} / \mathrm{s}$ sounds would be obliterated. If every vowel can represent, through its universal, all co-universal varieties, then the meta-element $/ \mathrm{T} /$ becomes universally restrictive (niyāmaka), and does not remain prescriptive (vidhäyaka) in any case. Thus /ã / could also represent eighteen co-universal varieties, like $/ \mathrm{a} /$.

Bhartrhari and Kaiyata do realize this problem. 92 They claim that $/ \overline{\mathbf{a}} /$ would not stand for $/ \mathrm{a} /$, because $/ \overline{\mathrm{a}} /$ involves additional effort. If $/ a /$ and $/ \bar{a} /$ both can represent all co-universal varieties, then why would one use $/ \tilde{a} /$ 
instead of $/ a /$ ? This is a very good practical argument, but it has no philosophical value.

3.19. Nāgeśa quotes a view held by some of the earlier grammarians. These grammarians think that /a/ expresses the pervading universal (vyāpaka-jāti), but $/ \bar{a} /$ expresses only a pervaded universal (vyāpya-jāti). This pervaded universal $/ \bar{a} /$-ness covers only long varieties. 93 But actually this does not work.

For instance, P. 7.2.84 (astana ā vibhaktau)

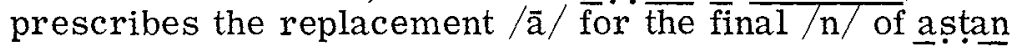
under certain conditions. Historically, the condition apratyayah "non-affixal" in P.1.1.69 (an-udit savarnasya cāpratyayah) restricts only affixes from homogeneousrepresentation, and does not apply to substitutes. 94 Thus, if $/ \bar{a} /$ can cover six co-universal varieties, including the nasal varieties, then by P.1.1.50 (stāne'ntaratamah), a nasal $/ \overline{\bar{a}} /$ would be substituted for the nasal $/ \mathrm{n} /$ of a Kătyãyana himself realized this difficulty. He answered it by pointing out that $/ \bar{a} /$ is a non $-/ a-N /$ sound, and hence it cannot stand for its homogeneous sounds by P.1.1.69. Therefore, only a non-nasal $/ \bar{a} /$ will be substituted for $/ \mathrm{n} /$ in astan. 95 But this solution would not really work in the procedure of universal-mention, if $/ \bar{a} /$ were to stand for a pervaded universal (vyāpya $-j a \overline{t i}$ ), covering all the long varieties.

3.20. There is another example which shows Pānini's preciseness of formulations, which would be totally disturbed in universal-mention. P.3.1.111 (i ca khanah) prescribes the substitute long $/ \mathrm{i} /$ for $/ \mathrm{n} /$ in the root khan and also an affix KyaP. Thus we have khan $+\underline{\text { KyaP }}$ leading to kha $+\underline{\bar{i}}+\underline{\mathrm{ya}}$, and finally to kheya. It seems strange that Pannini should give long $/ \bar{i} /$ as the substitute, instead of giving short $/ \mathrm{i} /$. Even Bhattoji Dikșita felt that Pānini should have given short $/ \mathrm{i} / .96$ As it is mentioned earlier, historically, substitutes in Pānini's grammar could represent their homogeneous sounds. Even Kātyāyana realized this fact, but it was later obscured by discussions in Patañjali. 97 If Pannini were to give short $/ \mathrm{i} /$ as the substitute for $/ \mathrm{n} /$ 
in khan, this short / $/$ being an $/ \mathrm{a}-\mathrm{N} /$ sound would represent its homogeneous varieties, including nasal varieties. Thus, $/ \mathrm{n} /$ would be substituted by a nasal $/ \tilde{\mathrm{i}} /$, finally leading to an undesirable nasal /e/ in khẽya*. Since Pānini realized this, he gave long $/ \bar{i} /$ as the substitute for $/ \mathrm{n} /$. This is not an $/ \mathrm{a}-\mathrm{N} /$ sound and hence it cannot represent any homogeneous sounds. Thus, there is no possibility of obtaining the undesirable form khẽya*. If we accept universal-mention, then $/ \bar{i} /$ could also cover its co-universal varieties and that would lead to the above mentioned problem.

3.21. From the above given analysis of universal-mention, it will be clear that it is not sufficient to replace Pänini's homogeneous-representation, unless a grammarian accepting this theory is prepared to build another structure of rules which would properly control its over-extensions. Kātyāyana seems to have given only a rough hypothesis. However, Kātyāyana's theory did not go unnoticed in the history of Sanskrit grammar. He had two illustrious followers, namely Candragomin and Sākațāyana. These two grammarians tried to develop Kātyāyana's suggestions in different ways. Their grammars will be studied later in Chapter XII. 



\section{CHAPTER IV}

\section{PATAÑJALI'S PROPOSAL OF PRAYATNA-BHEDA}

4.1. Pānini's rule P.1.1.9 (tulyāsya -prayatnam savarnam) says that two sounds having the same points of articulation and internal effort are mutually homogeneous. Then he formulates P.1.1.10 (nājjhalau) which denies mutual homogeneity to sounds denoted by the shortforms /a $-\mathrm{C} /$ and /ha $-\mathrm{L} /$. No vowels denoted by /a $-\mathrm{C} /$ are homogeneous with any consonants denoted by /ha $-\mathrm{L} /$. Since Pānini formulates this rule, we must assume that at least some vowels and consonants have the same internal effort. The tradition believes that, according to Pānini, vowels and üsmans, i.e./s/, /s/, /s/ and $/ \mathrm{h} /$ are vivrta "open. "98 There are many Siksās and other texts which do not subclassify these two groups according to their internal effort. 99 Thus, $/ \bar{a} /$ and $/ \mathrm{h} /$ are both kanthya "produced in the throat" and open. Similarly, $/ \mathrm{i} /$ and $/ \dot{\hat{s}} \overline{\mathrm{a}} \mathrm{re}$ both palatal and open. Thus these sounds would be mutually homogeneous, unless prevented by P.1.1.10 (nājjhalau). 100

4.2. Kātyāyana and Patañjali discuss problems concerning the interpretation of P.1.1.10. In the prima facie view (pürva-paksa), it is assumed that homogeneous-representation (P.1.1.69) applies to the terms /a $-\mathrm{C} /$ and $/ \mathrm{ha}-\mathrm{L} /$ in P.1.1.10. Kaiyata explains that, if P.1.1.69 is applied to P.1.1.10, then $/ \mathrm{i} /$ included in $/ \mathrm{a}-\mathrm{C} / \mathrm{could}$ stand for its homogeneous sounds including $/ \mathbf{s} / .101$ similarly, $/ \mathrm{a} /$ could stand for $/ \mathrm{h} /$. Normally, an exclusion rule applies first, and then the general rule applies. However, in this case, the negation rule has yet to come into being. We cannot deny homogeneity of /a $-\mathrm{C} /$ sounds with / ha $-\mathrm{L} /$ sounds, before interpreting these very terms, and there that denial cannot apply. Now if $/ \mathrm{i} / \mathrm{in} / \mathrm{a}-\mathrm{C} / \mathrm{stands}$ for $/ \mathbf{s} /$, and $/ \hat{\mathrm{s}} /$ also occurs in /ha-L/, then $/ \dot{s} /$ would be non-homogeneous with itself. Similarly, / $\mathrm{h} /$ included in $/ \mathrm{ha}-\mathrm{L} /$ is an $/ \mathrm{a}-\mathrm{N} / \mathrm{sound}$, and 
hence by P.1.1.69, it could stand for all varieties of $/ a /$. This would result in non-homogeneity of all the varieties of $/ a /$ with each other and with themselves. 102

4.3. Kātyāyana realized this problem. Thus, he says: 'In the prohibition [of homogeneity] between $/ \mathrm{a}-\mathrm{C} / \mathrm{and}$ /ha $-\mathrm{L} / \mathrm{s}$ sounds, the prohibition [of homogeneity] of $/ \hat{\mathrm{s}}$ / [with $/ \dot{\mathrm{s}} /$ obtains], since $[/ \hat{\mathrm{s}} / \mathrm{is}$ both] an $/ \mathrm{a}-\mathrm{C} /$ sound and a /ha-L/ sound."103 Patañjali explains that $/ \hat{\mathrm{s}} /$ is an /a $-\mathrm{C} /$ sound because it is represented by $/ \mathrm{i} /$, and it is a /ha-L/ sound because it is so listed in the group. 104 P. 8. 4.65 (jharo jhari savarne) prescribes deletion of a sound included in the group $/ \overline{j h a}-\mathrm{R} /$, if it is followed by a homogeneous sound from the same group, and preceded by any consonant. Patañjali points out that non-homogeneity of $/ \hat{s} /$ with itself would prohibit deletion of $/ \dot{s} /$ followed by $/ \dot{s} / .105$

4.4. To this difficulty, Kātyāyana offers two solutions. Here, we shall only be concerned with the first solution: "The desired result is achieved, since $[/ \overline{\mathrm{s}} /]$ is not an $/ a-C /$ sound. "106 This statement is given without any supporting reasons. 107 However, we have an explanation from Patañjali:

The desired result is achieved. How? [It is achieved], since $[/ \hat{s} /]$ is not an $/ a-C /$ sound. Why is $[/ \hat{s} /]$ not an $/ \mathrm{a}-\mathrm{C} / \mathrm{sound}$ ? [Consider the following:] The articulator of stops is in contact [with the point of articulation] . [The articulator] of semi-vowels is in slight contact. [The articulator] of üsmans is with a gap, i.e. open. Here the word "slight" continues. [The articulator] of vowels is also open. Here the word "slight" is not continued. 108

By subclassifying ūsmans as isad-vivrta "slightly open" and vowels as vivrta "open, "Patañjali avoids homogeneity of $/ \mathrm{i} /$ and $/ \hat{\mathrm{s}} /$. Thus $/ \mathrm{i} /$ cannot stand for $/ \hat{\mathrm{s}} /$, and hence the undesired non-homogeneity of $/ \hat{\mathrm{s}} /$ with $/ \hat{\mathrm{s}} /$ does not result. 
4.5. Patañjali's subclassification of vivrta "open" removes the particular problem, but at a great cost. It makes P.1.1.10 (näjjhalau) totally redundant. If ūṣmans and vowels differ in their internal effort, then actually there is no possibility whatsoever of any vowel ever being homogeneous with any consonant. Thus, there is no need for Pânini to make any rule such as P.1.1.10. Kaiyața realizes that Patañjali's suggestion leads to the rejection of P.1.1.10.109 This realization is also shared by later grammarians like Bhattoji Diksita. 110 But some of the later texts like the Laghusiddhānta-kaumudi of Varadaräja adopt this subclassification in their phonetic description. 111

The tradition clearly attributes this subclassification to Patañjali. 112 Actually, some later grammarians ascribe to Patañjali a sevenfold classification of internal effort by incorporating four subdivisions of vivrta, i.e. Isad-vivrta "slightly open," vivrta "open," vivrta-tara "more open and vivrta-tama "most open." 114' These distinctions are seen also in several other Ś Sikṣās and Prātisaakhyas. 115

Patañjali himself uses these distinctions to avoid homogeneity of /a/ [ which is presumed to be open within the grammar] with $/ \mathrm{e} /$ and $/ \mathrm{o} /$ which are said to be more open. 116 There are again differences of opinion in this respect. Nãgeśa holds that these subclassifications must be accepted to give a phonetic explanation of why /e/ and /o/ are not homogeneous with /ai/ and /au/.117 Otherwise, one must say that they are not homogeneous simply because Pãnini lists them separately in the Siva-sūtras.

4.6. Some of the later commentators show a clear awareness of the historically Päninian view in this matter. Thus, Bhattoji Diksita says that ūsmans and vowels have the same internal effort. 118 Hari Dikșita warns us that we should not believe that Pānini intends the distinctions given by Patañjali. 119 Nägeśa declares that the subclassifications of "open-ness" are not distinctive as far as homogeneity is concerned, and this is indicated by the fact that Pānini gives P.1.1.10.120 In one place Nãgeśa thinks that P.1.1.10 echoes Patañjali's subclassifications, 121 but later comes 
back and says that these distictions constitute a virtual rejection of P.1.1.10.122

4. 7. Historically, the question we may ask is if Patañjali invented this subclassification, or he just adopted an already established doctrine. Franz Kielhorn says:

Patañjali, in his comments on the vārttika: siddham anactvāt on P.1.1.10, appears (in the words: sprstạm karanam sparsāanām/ isat-sprștam

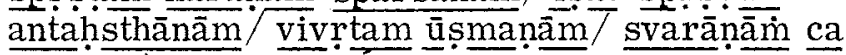
vivrtam) to quote a siksa which may have resembled the Apiśali, --unless indeed the rules given by him should have been quoted from the Atharvaveda Prätiśākhya I, 29-32 (spṛștam sparśānām karanam/

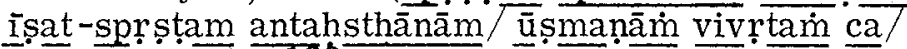
svarānāị ca) ."123

The Āpi sali-śiksā-sūtras which have come down to us read as follows: sprsțta-karanāh sparśāh/ ișat-sprsta -karanā

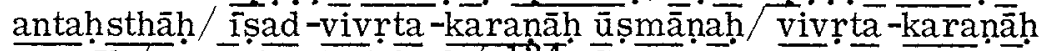

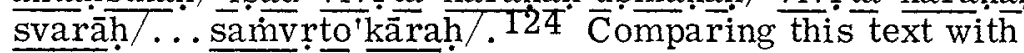
the text quoted by Patañjali, it is clear that he has not quoted the Âpiśali-śiksẫ -sūtras. There is a definite resemblance between the text quoted by Patanjali and the Atharvaveda Prātiśākhya. Thieme actually holds that Patanjali is quoting the $\mathrm{APr}$, and hence must be later than the APr. 125

It is, however, not clear if the APr exactly intends what Patañjali's interpretation seems to speak. On the APr I. 31 (ūsmanāim vivrtam ca), Whitney says:

The final ca of the rule indicates, according to the commentators, that isat-sprstam is also to be inferred from the previous rule: in the formation of the spirants, the organ is both in partial contact and open --a rather awkward way of saying, apparently, that its position is neither very close nor very open. 126 
The APr thus may not exactly be speaking of Patañjali's isad-vivrta, but it certainly differentiates spirants from vowels in their internal effort.

4. 8. This brings us to a new possible historical link. We have been using the name "Atharvaveda Prätiśākhya," along with Thieme and others, for a text, which actually bears the title Śaunakīyā Caturādhyāyikā, in the solitary Berlin MS from which it was edited by Whitney. Whitney gave it the title of APr. But new manuscripts bearing the title "APr" have come up, which are quite different from Whitney's APr. Important to us is the discovery of a manuscript titled Kautsa-vyākarana by Sadashiv L. Kãtre, in 1938 [ref. "Kautsa-Vyākarana:- A Detailed Notice," New Indian Antiquary, Vol. I, 1938-9, pp. 383-396] . This article gives all deviations of this Kautsa -vyākarana from Whitney's APr. Despite some minor divergences, these two texts are identical. This is extremely important. If this Kautsa is identical with Kautsa who is Pānini's disciple [ref: Mahābhāsya on P. 3.2.108: upasedivān kautsah panninim], that could substantially add to our knowledge of the historical development of the Pāninian tradition.

4.9. Hypothetically accepting Kautsa's identity as a student of Pānini, we may speak of some continuous historical development. Pānini did not subclassify vivrta "open," and thus has composed P.1.1.10. Then came his disciple, Kautsa, who in his Prātiśākhya did subclassify spirants and vowels. Then, we find Kātyāyana giving two alternatives to solve problems in P.1.1.10, i.e. a) anactvāt "since spirants are not vowels," and b) vākyāparisamäpter vã "incompletion of a sentence." As we shall see later, the second alternative is based on retaining P.1.1.10, which implies that vowels and spirants have the same effort. The firstalternative, however, distinguishes spirants from vowels. What is not clear is the ground on which this distinction is made. It is possible that Kātyāyana was aware of the distinctions made by Kautsa. We may find some tentative support to conclude that Kătyāyana knew the difference concerning internal effort of vowels and spirants. Thieme 
has almost conclusively proved the identity of Kātyāyana, the Vārttikarkāra, and Kătyāyana, the author of the Vājasaneyi Prāriśākhya [see: n. 284] . The definition of savarna in the VPr [see: 10.5.2] is virtually identical with $\overline{P .1 .1} \cdot \overline{9}$, and yet there is no homogeneity of any vowels with spirants, since, as Uvata points out, vowels are asprsțta "without contact" and spirants are ardha -sprșta "with halfway contact." With the same assumption, perhaps, Kātyāyana differentiated vowels and spirants in his vārttika: anactvāt on P.1.1.10. However, realizing that this is not Pānini's view, he offered the other explanation: vākyāparisamāpter vā. Finally, Patañjali came out with explicit discussion of this problem. Thus, this suggestion of prayatna-bheda can be ascribed to Patañjali, only in the sense that he came out with this explicit discussion for the first time in the Pāninian tradition.

4.10. Anyway, Patañjali does not stand alone in differentiating the internal effort of spirants from that of vowels. The Yajus recension of the Panniniya-śiksa (verse 30) considers vowels to be asprsța "without contact" and spirants to be nema -sprsta "with halfway contact. "127 But the preceding verse itself considers vowels and spirants to be vivrta "open."128 The Päniniya-sikșā-sūtras say that spirants may be considered either isad-vivrta or vivrta. 129 These sutras which are probably of a late origin seem to record $\overline{b o t h}$ the traditions. The Âpisali-śiksā-sütras, without option, consider spirants to be isad-vivrta. 130 This has prompted certain scholars to consider this Siksā to be post-Pāninian. 131 Uvata's commentary on the $\overline{\mathrm{VPr}}, 132$ the Yâjnavalkya -śikșā 133 and the Varna -ratna-pradipikāsiksā of Amaresa 134 consider spirants to be ardha-sprsta "with halfway contact." The terms nema-sprsta and ardhasprsta seem to combine the notion of the APr that spirants are both issat-sprsța "with slight contact" and vivrta "open." The term isad-vivrta seems to have originated with Patanjali's discussion. 


\section{A NON-TRADITIONAL APPROACH}

5.1. By a non-traditional approach, I intend the following axioms: a) A rule can apply to itself, and b) a rule can apply to another rule, even if the first presupposes the second. In the present context, this would mean that P.1.1.69 applies to itself, and it also applies to P.1.1.10. In the Paninian tradition, no one has adopted this view, which amounts to a criticism of the notion of vākyāparisamāpti "incompletion of a sentence," a procedure adopted by Kātyāyana and the rest of the Pāninian tradition. The details of this procedure will be discussed in the following chapter, but basically it says that P.1.1.69 cannot apply to itself, nor to P.1.1.10. S. P. Chaturvedi (1933) launched a heavy criticism of this traditional way of interpreting Pānini. He says that the procedure of vākyāparisamāpti "which is propounded by Bhāṣyakāra Patañjali... should be regarded as ekadeśi -bhāsya and not as a siddhānta -bhāsya" [Chaturvedi (1933), p. 168] . He further says:

This doctrine cuts at the very root of the Pāninian system and its acceptance will lead to many complications. The Asțādhyāyī of Pānini is a whole interconnected work. "For the formation of a single word, we have to apply sūtras from various parts of the work. Each sūtra should be interpreted in the light of what we know from the other sūtras. It is wrong to maintain that at the time of interpretation of nājjhalau-tulyāsya-prayatnam savarnam (I.i.9, 10), we connot take help from the sūtra anuditsavarnasya cāpratyayah (I.i.69), its meaning being still unknown to us according to vākyāparisamāptinyāya. When we interpret the pratyāhāra 'ac' in nājjhalau, we should do so as we interpret other pratyāhāras in the Asțāâdhyāyĩ. [Chaturvedi (1933), p. 170] 
With this argument, Chaturvedi criticizes Bhatțoji Dikșita and proposes that either we should apply P.1.1.69 to P.1.1.10 and abandon vākyāparisamāptinyāya or accept the subclassification of vivrta "open" [Chaturvedi (1933), p. 173] . p. 173]. As we shall later discuss in detail, Chaturvedi's argument is wrong on several counts. The vākyāparisamāpti precedes Patañjali and is found in Kātyāyana, who uses it in many contexts as the only explanation of apparent problems in Pănini's rules. [Sec. 6.14-15]

No other scholar has openly accepted a view like Chaturvedi's, but there are many cases of implied acceptance. For instance, S. C. Vasu translates P.1.1.69 as:

The letters of the pratyāhāra a -Ṇ, i.e. the vowels and semi-vowels, and a term having $\underline{u}$ for its indicatory letter refer to their own form as well as to their homogeneous letters, except when they are used as pratyayas. 135

With this goes the comment:

The pratyāhāra a-N in this sūtra includes all the vowels (underlining mine) and liquids. 136

This is clearly applying P.1.1.69 to P.1.1.69. Let us also glance at Vasu's translation of P.1.1.10.

There is, however, no homogeneity between vowels and consonants. 137

Colebrook, Böhtlingk and Renou have exactly parallel translations. 138 The term $/ \mathrm{a}-\mathrm{C} /$ in $\mathrm{P} .1 .1 .10$ cannot mean all vowels, unless P.1.1.69 is applied to P.1.1.10. Without its application, /a-C/ would stand only for $/ \mathrm{a} /$, $/ \mathrm{i} /, / \mathrm{u} /, / \mathrm{r} /, / \mathrm{l} /, / \mathrm{e} /, / \mathrm{o} / \mathrm{,} / \mathrm{ai} /$ and $/ \mathrm{au} /$ as they are listed in the Siva-sūtras. This would indicate that these scholars have applied P.1.1.69 to P.1.1.10.

5.2. Recently, S. D. Joshi has provided some discussion of P.1.1.69 and its interpretation. Kaiyața quotes an 
older maxim: grahanān-grahane grahanābhāvah, which is rendered by S. D. Joshi as: "(OOne can) not (apply the principle of) grahana (i.e. P.1.1.69) to the term $/ \mathrm{a}-\mathrm{N} /$ in the grahana rule (itself). "139 In a footnote to this, he says: "The pratyāhāra /a $-\mathrm{N}$ / includes all vowels (underlining mine), semi-vowels and $/ \mathrm{h} / . " 140$ This is quite similar to Vasu's comment and implies that Joshi is applying P.1.1.69 to itself. In fact, S. D. Joshi is quite aware of the exact meaning of the traditional maxim and of some of the effects of not accepting it. This is what he has to remark:

The quotation is probably from the lost part of Bhartrhhari's Mahābhāșya-Dīpikā. The term/aN/ in P.1.1.69 refers only to those vowels which are included in the pratyāhāra /aN/. The rule P.1.1.69 states that these vowels represent their homorganic varieties also. Now if P.1.1.69 is applied in P.1.1.69 itself, it would give the meaning that the vowels included in /aN/ and their savarna (homorganic) varieties stand for their savarna varieties. This means that the vowels long $/ \bar{a} / \overline{\text { etc }}$. also represent the corresponding short varieties. 141

The reader is not sure if S. D. Joshi prefers applying the rule to itself, as his footnote would have us believe, or he is simply explaining what would happen if the rule applies to itself. In view of this confusing state of affairs, we need to go into a detailed examination of this alternative. Some of the alleged examples of a rule applying to itself are P.1.3.3 (hal-antyam) and P. 7.3.119 (ac ca gheh). We shall discuss these cases critically and study the question of a rule applying to itself in more general terms.

5.3. P.1.3.3 (hal-antyam) literally means: "The final hal is termed it." Does the term hal in the rule stand for the Siva-sūtra: /ha-L/, or does it represent the shortform /ha-L/? The rule which forms shortforms, i.e. P.1.1.71 (ādir antyena sahetā), says: "The initial sound, along with the final it sound, stand for the initial sound and the sounds which are in between." This rule presupposes the definition of it, i.e. P.1.1.3. On the other hand, if $/$ ha $-\mathrm{L} /$ in P.1.3.3 
is to be a shortform, it presupposes P.1.1.71. This is a case of interdepencence. 142 Kātyāyana's final solution to this problem runs as: "[ The desired result is established] alternatively by [considering hal in P.1.3.3 to be] a mention [ of both the Siva-suttra: /ha-L/ and the shortform/ha-L/] by a single-remainder transformation (ekaśesa). "143 Patañali says that hal in the rule, by single-remainder, stands for two words of the same shape. 144 For instance, the dual rāmau is derived, in Pānini's system, from two singulars, i.e. rāmah and rāmah̆, which have the same phonetic shape and the same case, by P.1.2.64 (sarüpänäm ekaseșa eka-vibhaktau). Kaiyata believes that the first word $/ \mathrm{ha}-\mathrm{L} /$ is a genitive Tatpurusa compound meaning "/// near /ha/" (hasya lah). The second word /ha-L/ is a shortform. 145 Thus the first interpretation of P.1.3.3 is: "The sound near $/ \mathrm{ha} /, / 1 /$, is it." Then by P.1.1.71, we can form the shortform $/ \mathrm{ha}-\mathrm{L} /$ beginning with $/ \mathrm{h}(\mathrm{a}) / \mathrm{in}$ the Siva-suitra: $/ \mathrm{h}(\mathrm{a}) / / \mathrm{y}(\mathrm{a}) / / \mathrm{v}(\mathrm{a}) / / \mathrm{r}$ (a) $/ \mathrm{T} /$ and ending in the marker $/ \mathrm{L} /$ of the Siva-sutra: $/ \mathrm{h}(\mathrm{a}) / \mathrm{L} /$. This covers all consonants. With this shortform /ha-L/. we come back to P.1.3.3. Now the rule means that all consonants occurring at the end of given units are termed it. Nāgeśa doubts Kaiyata's interpretation of genitive compound, 146 and thinks that Patanjali has actually opted for repeating the rule. This is the interpretation of Bhattoji Dikșita. 147

This repetition of the rule and separate interpretation of the two instances of P.1.3.3 is designed to avoid mutual dependence with P.1.1.71, as well as for avoiding the so-called application of P.1.3.3 to itself. What we have are two rules with the same wording, and not one and the same rule being applied to itself. It is clear that the two interpretations of P.1.3.3 do not apply to each other, and also they do not apply within themselves.

5.4. Another alleged instance is P. 7.3.119 (ac ca gheh). In the rule, we have the form gheh, genitive singular of the stem ghi -. The technical term ghi-stands for nominal stems ending in short $/ i /$ and $/ u /$, excluding sakhi- and those nominals which are termed nadi (P.1.4.7 (sieso ghy asakhi)). The word ghi-itself fulfills all the conditions for 
the technical designation ghi-. The commentators admit that only because ghi - is termed ghi-, can we have guna replacement of $/ i$ in ghi in the form gheh by P.6.1.1i (gher niti). 148 Thus the technical term ghi applies to ghi-itself.

5.5. This is quite different from saying that a rule applies to itself. We have to make a distinction between the expression of a rule and its contents. If the theoretical contents of a rule apply to themselves, then it is a case of a rule applying to itself. However, if the contents of a rule apply to the expression of itself, then this is a different kind of dependence. As linguistic utterances, there is actually no difference between the expression of a grammatical rule and a sentence in a drama. The traditional grammarians have squarely dealt with this problem. For instance, in terms of contents, P.6.1.101 (akah savarne dirghah): "If an /a-K/ sound is followed by a homogeneous sound, both are replaced by a long variety" is dependent on P.1.1.9 (tulyāsya-prayatnam savarnam) which defines homogeneity. However, in the expression of P.1.1.9, we have a sandhi of tulya and āsya, which depends on the contents of P.6.1.101. Bhattoji discusses this example and points out that as linguistic utterances illustrating a certain grammatical feature, there is no difference between the expressions tulyāsya and dandādhaka. 149 Thus, P. 7.3.119 is not an example of a rule applying to itself.

5.6. Some grammarians held that sandhi rules do not apply to the Siva-sūtras because the sandhi rules have yet to come into being. The expression of sandhi rules depends on shortforms, which depend on the Siva-sūtras. Nāgeśa points out that this is a false argument. The rule which applies in upendra should also apply in $/ a-i-u-N /$. The reason there is no sandhi is that it would create a lot of confusion in identifying the sounds in the list. This is the real reason. 150

5. 7. We have already considered the undesirable effects of applying P.1.1.69 to P.1.1.10, in Sec. 4.2-3. Here we shall discuss the effects of applying P.1.1.69 to itself. 
We already have some hints from S. D. Joshi. Here we have also to consider P.1.1.70 (taparas tatkālasya). This rule says: "A sound marked with /T/ stands only for the homogeneous varieties of the same quantity." If we do not apply P.1.1.69 to itself, then we have the following:

$[1] / \mathrm{a} /$ stands for eighteen varieties.
$[2] / \bar{a} /$ stands for itself.
$[3] / \mathrm{aT} /$ stands for six short varieties.
$[4] / \bar{a} \mathrm{~T} /$ stands for six long varieties.

If we apply P.1.1.69 to itself, then we have the following:

[B]

$$
\begin{aligned}
& {[1] / \mathrm{a} / \text { stands for eighteen varieties. }} \\
& {[2] / \overline{\mathrm{a}} / \text { stands for eighteen varieties. }} \\
& {[3] \mathrm{aT} / \text { stands for six short varieties. }} \\
& {[4] / \overline{\mathrm{a}} / \text { stands for six long varieties. }}
\end{aligned}
$$

This shows the difference between the two alternatives. The alternative [B] is very much like Kätyāyana's theory of universal-mention. If $/ \bar{a} /$ or any non $-/ a-N /$ sound could represent its homogeneous varieties, that creates problems which are common with Kātyāyana's universal-mention. [cf. Sec. 3.18].

5. 8. There are also other implications of applying P.1.1.69 to itself. In this alternative, the difference between $/ \mathrm{a}-\mathrm{N} /$ sounds and non $-/ \mathrm{a}-\mathrm{N} / \mathrm{sound}$ is obliterated. The same would apply to sounds marked with $/ \mathrm{U} /$, and sounds represented by sounds marked with $/ U /$. Non $-/ a-N /$ vowels and semi-vowels would be capable of representing their homogeneous sounds. Similarly, sounds marked with /U/ and sounds represented by such sounds would also be capable of representing their homogeneous sounds. Just as $/ \bar{a} /$ could represent all the eighteen varieties, similarly $/ \mathrm{kh} /$ could also represent $/ \mathrm{k} /, / \mathrm{kh} /, / \mathrm{g} /, / \mathrm{gh} /$ and $/ \mathrm{n} /$. The same would happen to other series of stops.

5.9. Though this is obviously not what Pānini intended, such an implication seems to follow from $\dot{V}$. N. Misra's translation of P.1.1.69: 
A member of the $/ \mathrm{a}-\mathrm{N} / 2$ group (vowel, semi-vowel and $/ \mathrm{h} /$ or of the groups $/ \mathrm{kU} /, / \mathrm{cU} /, / \mathrm{tU} /, / \mathrm{tU} /$, $/ \mathrm{pU} /$, stands for itself as well as for its homorganic correspondents, but only when it is not a component of a suffix. 151

Misra speaks of the group /a -N/2 as "vowel, semi-vowel and $/ \mathrm{h} /$ " and not just sounds as listed in the Siva-sūtras. Thus, he is certainly applying P.1.1.69 to itself. Misra goes even further. The other part of his translation could mean two things. It may mean that each of the groups $/ \mathrm{kU} /$ etc. stands for itself and its homorganic correspondents, or any member of any of these groups stands for itself and for its homorganic correspondents. Both of these are inaccurate statements.

5. 10. All the above discussed implications of applying P.1.1.69 to itself would come to mean that all vowels, semi-vowels and stops are capable of representing their homogeneous varieties. If this were Pānini's intention, he could have formulated the shortform $/ \mathrm{a}-\mathrm{Y} /$ to cover all these sounds and could have formulated P.1.1.69 as: ay savarnasya cāpratyayah. Actually such an interpretation of P.1.1.69 would seriously put Pānini's entire grammar in jeopardy. This searching analysis would show that the alternative of applying P.1.1.69 to itself is neither historically Pāninian, nor theoretically effective, and hence must be abandoned. 



\section{BACK TO PÄNINI}

6.1. After considering the un-Pāninian alternatives, we now come back to an interpretation, which in all probability is Pāninian. On P.1.1.10, Kātyāyana first presents a prima facie view that P.1.1.69 applies to P.1.1.10. The problems resulting from this have been discussed in Sec. 4.2. To solve these problems, Kātyāyana offers two solutions. The first solution and its interpretation by Patañjali are also discussed in Sec. 4.3-4. The second solution given by Kātyāyana initiates the procedure of vākyāparisamāpti "incompletion of a sentence." Kātyāyana says: "The desired result that $/ \dot{s} /$ is homogeneous with itself, and is not homogeneous with / $/$ / is established] alternatively by [adopting the procedure of] incompletion of a sentence." 152 On this Patañjali gives the following explanation:

What is this incompletion of a sentence? First there is the teaching of sounds [in the Siva-sūtras]. [The definition of] the term it [in P.1.3.3] follows the teaching of sounds. [The definition of] a pratyāhāra "shortform" [i.e. P.1.1.71] follows [the definition of] the term it. [The definition of] the term savarna "homogeneous" [in P.1.1.9] follows [ the definition of] shortforms. [The definition of] savarna-grahana "homogeneous representation" $[$ in $P .1 .69]$ follows [ the definition of] the term "homogeneous." By this complete and interlinked sentence, there is representation of homogeneous sounds elsewhere [but not within any link of this sentence]. 153

The Pāninian procedure of homogeneous-representation is built up of five stages, each of which is dependent on the 
previous stage, and all the five stages are linked together like clauses of a complex sentence. To some extent, this linking could be compared with an inferential process, where the product of a previous inference becomes the premise of the next inference. The Naiyāyikas consider stages within an inference to be like clauses of a sentence, and hence the expression of a full inference used to convince others (parārtha) is called a "five-limbed sentence" (pañcāngikavākya). 154 Representation of homogeneous sounds is the cumulative effect of this ordered sequence of rules, and the procedure does not apply to any rule within the closed group.

6.2. Patañjali says that the definition of the term savarna "homogeneous" follows the definition of shortforms. This is at first confusing. P.1.1.9 (tulyãsya-prayatnam savarnam) does not involve any shortforms, and does not depend on the definition of shortforms (P.1.1.71). However, as Bhatțoji Dikșita points out, P.1.1.10 needs to be interpreted before P.1.1.9. P.1.1.10 (nājjhalau) literally means: "The sounds denoted by the shortforms /a-C/ and /ha-L/ are not mutually homogeneous." This rule involves two shortforms. According to the Pāninian tradition, an exception rule is to be interpreted before interpreting the general rule. The same sequence belongs to their application. 155 If we first have mutual homogeneity of /a $-\mathrm{C} /$ and /ha $-\mathrm{L} /$ sounds by P.1.1.9, and then deny it by p. 1.1.10, it would be like asking a man who has already eaten not to eat. 156 Thus, the definition of homogeneity indirectly depends on the definition of shortforms. We cannot interpret P.1.1.69 before interpreting P.1.1.9, since we cannot interpret the procedure of homogeneousrepresentation before defining "homogeneous." This ordered dependence of rules is the essence of incompletion of a sentence, for any rule within the structure. 157

6.3. The reason why P.1.1.69 cannot apply to P.1.1.10 is that we cannot understand P.1.1.69 before interpreting P.1.1.9, and P.1.1.9 cannot be interpreted before interpreting P.1.1.10. Thus, in a way, $\mathrm{P}$.1.1.69 does not exist, while interpreting P.1.1.10.158 Hari Dikșita points out that what counts is the logical or cognitive sequence of 
rules in terms of their dependency requirement. 159 Thieme explains this situation:

Bezüglich der in Pān.1.1.10 (nājjhalau "ein 'acc' und ein 'hal' sind nicht gleichlautig") genannten pratyāhāra hat zwar 1.1.69 nicht statt, da erst nachdem die Definition der 'Gleichlautigkeit' vollständig gegeben ist, der Ausdruck savarnasya in 1.1 .69 verstanden werden kann. An anderen Stellen der Grammatik, wo ein pratyāhāra genannt wird, hat jedoch 1.1.69 statt, und nennen die in den pratyāhāra enthaltenen Laute auch ihre 'gleichlautigen' Partner, z. B. das in akah in 6.1 .101 enthaltene $/ \mathrm{i} /$ auch langes $/ \tilde{\mathrm{I}} / .160$

Thus, P.1.1.69 does not apply to P.1.1.10.

6.4. Similarly, P.1.1.69 cannot apply to itself. Bhartṛhari explains the logic behind this:

However, here in P.1.1.69, there is no homogeneousrepresentation by P.1.1.69. What is the reason? In this rule (i.e. P.1.1.69), the relation of a sound with the designated items (i.e. homogeneous sounds) is not yet established. [Thus] the rule of homogeneousrepresentation does not apply to the shortform /a-N/ in the same rule, because [a] the procedure of representation has not yet come about, [b] there is no other rule of such representation, and [c] an action [ of a thing] is contradicted with respect to the same [thing] . 161

Thus, while interpreting a statement, we cannot take for granted its own meaning. Otherwise, we would be involved in the fallacy of circularity. Finally, Bhattoji Dikșita points out two historical aspects of this procedure. In this procedure, both P.1.1.10 and P.1.1.69 are necessary, and vowels and spirants have the same internal effort. 162 Compared to other alternatives, these aspects make this alternative more historically true to Pānini's system. 
6.5. At this point, we have to dive deeper into some of the most fundamental aspects of Pānini's theory of homogeneity. He felt the necessity of adopting this procedure of homogeneous-representation, because the features of pitch, nasality and quantity are basically distinctive. On P.1.1.1 (vroddhir ād-aic), Kātyāyana says: "The marker $/ \mathrm{T} /$ is attached to $/ \bar{a} /[$ In P.1.1.1] to obtain [representation of] homogeneous sounds [of the same quantity]. Since pitch is a distinctive feature, [the non $-/ \mathrm{a}-\mathrm{N} /$ sound $/ \overline{\mathrm{a}} /$ cannot by itself stand for any of its homogeneous sounds] . "163 The sound $/ \bar{a} /$ as uttered by Pānini must have had some pitch, and it must be distinct from $/ \bar{a} /$ sounds with a different pitch. Thus, $/ \bar{a} /$ with a certain pitch, by itself, cannot stand for $/ \bar{a} /$ with a different pitch. Since $/ \bar{a} /$ is a non $-/ a-N /$ sound, P.1.1.69 cannot help it. Thus, addition of the marker $/ \mathrm{T} /$ is the only solution.

Patañjali, on the other hand, holds a different view. He counters Kătyãyana's explanation with the following comment:

The only correct view is that [for Pānini] the features [of pitch etc.] are not distinctive. What is the basis for such a view? The reason is that [Pānini] specifically states a certain vowel to be highpitched in P.7.1.75 (asthi -dadhi -sakthy -akșnām anañ udāttah). If the features were distinctive, then he might have simply uttered the highpitched vowel. 164

If these features are not distinctive, it does not matter with what feature Pānini pronounced $/ \bar{a} /$ in P.1.1.1; it will still represent other varieties of $/ \bar{a} /$, without $P$.1.1.69. Patañjali clearly says: "Thus, the marker /T/ in P.1.1.1 is simply to remove doubts, ".165 and has no prescriptive function as interpreted by Kātyāyana.

6.6. Despite Patañjali's arguments, Kătyãyana's view has a richer significance. It represents the historical truth as far as Pănini's original system is concerned. Pānini needed homogeneous-representation, because basically, 
pitch, nasality and quantity are distinctive. This has been brought out by Kătyāyana: "Because of the difference of [sounds on account of] pitch, nasality and quantity, [Pānini made the rule that $]$ an $/ \mathrm{a}-\mathrm{N} / \mathrm{sound}$ represents its homogeneous sound."166 Kātyāyana consistently maintains his view throughout. A sound cannot stand for another sound with different features, unless such a capacity is invested by P.1.1.69, or by the marker $/ \mathrm{T} /$. Bhartrhari testifies that this was Pānini's view. 167 The later tradition mostly follows Patañjali's view, but some grammarians have exhibited a historical attitude. Nägeśa points out that Pānini's rule P.1.1.69 is made with a view that features are distinctive and that a sound basically stands only for itself (vyakti-vāda) ${ }^{168}$ Nilakaṇtha Dikșita says that the maxim abhedakāh gunāh "Features are not distinctive" is not universally valid, because of Pannini's inclusion of the $/ \mathrm{a}-\mathrm{N} /$ sounds in P.1.1.69.169

6.7. In fact, both the so-called opposite views do not contradict each other, if understood in a specific manner. Pannini starts with the real pronounced sounds of the object language, where the features of pitch, quantity etc. are phonemically distinctive. For instance, the final sounds in śyāma and śyāmāa are phonemically different. Similarly, the two Vedic words, i.e. bráhman and brahmán are phonemically distinct from each other. This is the level Kätyāyana is talking about, when he considers these features to be distinctive.

However, those features which are phonemically distinctive are not necessarily so in morphophonemics. For instance, both $/ a /$ and $/ \bar{a} /$ in śyāma and śyāmā take the same guna replacement $/ \mathrm{e} /$, if they are followed by $/ i /$ in iti, yielding syāmeti. Thus, the feature of quantity is not distinctive with reference to this morphophonemic operation. Similarly, in a large number of rules in Pānini's grammar, these features are morphophonemically nondistinctive. This is what Patañjali intends to say. Nāgeśa rightly interprets Patanjali's view to mean that the features like pitch do not cause non-homogeneity of sounds. 170 Thus, Kātyāyana's view belongs to a pre-homogeneity stage, while Patañjali's view, in this moderate 
interpretation, belongs to a post-homogeneity stage.

In fact, Patañjali seems to agree with Kātyãyana, when he says: 'The designation 'homogeneous' is founded on the difference [between sounds, in features other than the point of articulation and internal effort]. If it were to apply [to sounds] where there is total identity [of features], the designation 'homogeneous' would serve no purpose. "171

6.8. Thus, there is no contradiction in saying that a feature such as pitch is phonemically distinctive, while it is morphophonemically non-distinctive. This has been achieved by Pănini through his conception of savarna "homogeneous" and savarna -grahana "homogeneous -representation." Each /a-N $\mathbf{Y}$ sound in the Siva-sütras is phonemically distinct from other homogeneous sounds, because of the difference of pitch, nasality and quantity. However, through the procedure of homogeneous-representation, it becomes morphophonemically non-distinct from other homogeneous sounds. Thus a morphophonemic operation prescribed with respect to $/ \mathrm{a} /$ also applies to $/ \overline{\mathrm{a}} /$, unless prevented by $/ \mathrm{T} /$.

When Pānini wanted certain sounds to be marked with distinct features even in morphophonemics, he used special devices like the condition apratyayah "nonaffixal" in P.1.1.69, the marker / T/ defined by P.1.1.70 to limit the quantity of the represented homogeneous sounds, and specific mention of accentual features in rules such as P.7.1.75. Thus, homogeneous-representation is a process of selecting features which are common to a group of sounds undergoing identical morphophonemic operations, and of keeping aside the phonemically distinctive features which are morphophonemically not pertinent.

6.9. After this question, we need to investigate a still deeper question. This is the basic notion of identity and difference between sounds. Can a sound $/ a /$, say low pitched, non-nasal and short, stand for another low-pitched, non-nasal and short $/ \mathrm{a} /$, without the help of P.1.1.69? For instance, is $/ a /$ in $/ a /-/ i /-/ u /-/ N /$ able to cover $/ \mathrm{a} /$ in P.7.4.32 (asya cvau), without P.1.1.69? Are the 
two /a/-s identical or are they different? P.1.1.69 is prescribed with reference to $/ \mathrm{a} /$ in $/ \mathrm{a} /-\mathrm{i} /-/ \mathrm{u} /-\mathrm{N} /$, and if this /a/ is different from /a/ in P.7.4.32 (asya cvau), then P.1.1.69 may not apply to /a/ in P.7.4.32. Kātyāyana, on the first Siva-sūtra, does foresee this objection: "In the secondary references, there would be no representation of homogeneous sounds, because they might not be regarded to be /a-N/ sounds." In the course of a long winding discussion, Kätyāyana proposed three solutions to this problem. They are as follows:

[A] The desired result is established, since there is only one single real /a/ sound. 173

[B] The desired result is established, since there is universal-mention. 174

[C] [The desired result is established] alternatively by relying on identical features [of different sounds] .175

The explanation $[\mathrm{B}]$, the procedure of universal-mention, has already been discussed at length. It is historically un-Pāninian, since it constitutes a total rejection of P.1.1.10 and a partial rejection of P.1.1.69.176 In what follows, we shall discuss the other two alternatives and search for a clue in Pānini's rules.

6.10. ONTOLOGICAL IDENTITY THEORY. The alternative [A] says that the sound $/ \mathrm{a} /$ in $/ \mathrm{a} /-/ \mathrm{i} /-/ \mathrm{u} /-\mathrm{N} /$ and in P. 7. 4.32 is a numerically identical single real sound, which is manifested time and again. The same real sound appears in the Siva-sütra, secondary references and verb-roots etc. 177 This view is based on the dichotomy between a real eternal sound, and its various non-eternal manifestations. In order that two manifestations should represent the same real sound, they must have identity with respect to all distinctive features. However, Kaiyata says that the difference of pitch belongs to the manifesting sounds and not to the real sound. 178 It is doubtful if Kâtyāyana meant this. The arguments offered by Kātyāyana to defend identity of a real sound through different manifestations are very similar to those found in Sabara. 179 It is possible that Kătyāyana developed this theory of identity of a real sound on the basis of Vyädi's 
doctrine of Vyakti -vāda, which he quotes extensively. The standard example is that of the sun. The same sun at the same time happens to be seen in different places. The other example is that of Indra. Indra, being invoked simultaneously by a hundred different sacrificers, appears in all those different places at the same time. These arguments are used to extablish the unitary character (ekatva) and eternality (nityatva) of the real sounds. The manifesting sounds, however, are infinite and are non-eternal. Thus, there are eighteen real /a/ sounds. 180 There is no necessary relation between eternality and unitary character of a sound. Bhartrhari says that there were some philosophers who held that sounds were eternal and unitary, while others held that they were unitary but not eternal. 181

Kaiyata is aware that P.1.1.69 is formulated on the basis of vyakti -vāda "doctrine of individual."182 Nāgeśa also acknowledges that this is the solution for applying P.1.1.69 to $/ \mathrm{a} /$ in P. 7.4.32 (asya cvau). 183 This doctrine of eternal real sound-individuals, like the doctrine of eternal sound-universals, is dependent on a great deal of metaphysical argumentation. Kātyāyana probably took it from the early school of Vyāọi's Mímāmsā, and it is later seen adopted with much more sophistication in Jaimini's Mīmāmsā.

6.11. FEATURAL IDENTITY THEORY. Kātyāyana also presents the opposite doctrine, namely that $/ \mathrm{a} /$ in $/ \mathrm{a} /-/ \mathrm{i} /-/ \mathrm{u} /-\mathrm{N} /$ and in $\mathrm{P} .7 .4 .32$ are actually two different sounds, and that each instance constitutes a different sound. The two /a/ sounds have to be different sounds, since they could be separated by time, by other sounds and be simultaneously in different places. 184 Patañjali gives the example danda agram to show two /a/ sounds separated by time, and the example dandah to show two $/ \mathrm{a} / \mathrm{sounds}$ separated by other sounds. If/a/ were only one real sound, it could not be seen simultaneously in different words. Devadatta cannot be simultaneously in the cities of Srughna and Madhurā. 185 Though $/ \mathrm{a} /$ sounds in $/ \mathrm{a} /-/ \mathrm{i} /-/ \mathrm{u} /-\mathrm{N} /$ and P.7.4.32 are different sounds, they do not differ in any distinctive features, and hence are featurally identical with each other. Though there is no real identity, as in the 
previous view, still there is featural identity. On the basis of this featural identity, both are considered to be /a-N/ sounds. The examples given by Patañjali are very interesting. One of the examples is: "We eat the same rice [here], which we used to eat in the Magadhas."186 Obviously it is not the same rice, but the varieties of rice do not differ in any essential features. Bhartrhari further clarifies the philosophical basis of this alternative:

How is this a solution? Some grammarians explain as follows: Even if there is no universal property (ākrti), still there is no problem. Just as there is no universal property in different coins; but you have a coin in the city of Mathurā and it is still an item of money. 187

In terms of grammar, this means that a low-pitched, short, non-nasal /a/ naturally covers /a/ with the same features. This view does not presume any universals. It also does not presume eternal sound-individuals. Thus, it is philosophically a non-commital view, and depends more on common sense. This featural identity is much more exacting than the conditions of homogeneity. Homogeneity requires identity of only two distinctive features, while the argument here requires total featural identity. The sounds with such total identity of distinctive features may, however, differ in features such as speed (vrtti). Features like these are considered to be phonemically non-distinctive by Kātyāyana. 188

6.12. There are certain hints in Pānini's grammar which indicate that Pānini favoured the non-ontological alternative of total featural identity (rūpa -sāmānya), instead of committing himself to either eternal sound-individuals or eternal sounduniversals. The rule P.1.1.68 (svam rūpam șabdasyāsabdasamjna) says that a word in grammar stands for its own form or phonetic shape (rūpa), and not for its conventional meaning, unless it is a technical term in grammar (s̉abda-samjñā). Here, Pănini has utilized the notion of rüpa "phonetic shape or form" of a word. Pānini also uses the notions of sarūpa "with identical phonetic shape" and asarūpa "with different phonetic shape." [P.1.2.64 (sarūpāṇām ekaśesa eka- 
vibhaktau) and P. 3.1.94 (vā'sarūpo'striyām)]. The words rāma 1 "Rāma, the son of Daśaratha" and rāma 2 "Paraśurāma, the son of Jamadagni" differ in meaning and yet they are sarūpa "with identical shape." However, rāma and ramā are asarūpa "with different phonetic shape." Similarly the affixes /aN/ and $/ \mathrm{Ka} /$ are sarüpa, because markers do not cause difference in the phonetic shape of the affix. In all these cases, the features of quantity etc. are distinctive. Thus, /áa and /á / are sarūpa "with identical phonetic shape," but $/ \hat{a} /$ and $/ \hat{a} /$, or $/ \hat{a} /$ and $/ \hat{a} /$ are not with identical phonetic shape. Thus, we may say that if two sounds are sarūpa "with identical phonetic features," then we do not need homogeneous-representation for one to cover the other. This is the direct implication of P.1.1.68. However, if two sounds are asarūpa "without having all identical phonetic features," and if they have the same point of articulation and internal effort, then they are homogeneous with each other, and by the procedure of homogeneous-representation (P.1.1.69) one may cover the other. There seem to be thus two principles in Pānini's grammar, i.e. sārūpya "total featural identity" and sāvarnya "homogeneity, or identity of two features."

This may indicate that Kätyāyana's third alternative in fact represents the view held by Paninini. This is also a justification for Kätyāyana's view that, in Pānini, the features of quantity etc. are basically distinctive, and hence Pānini needed the procedure of homogeneous -representation. 189 Kātyãyana says that difference in speed (vrtti) does not affect duration of real sounds (varna), which are fixed in their duration (avasthitāh). 190 This indicates that the difference in quantity does differentiate sounds from one another, while speed does not. This is clearly understood by Kaiyața who says that short, long and extra-long sounds are basically different sounds, and are manifested by different physical sounds. Hence, the difference in quantity is real difference. 191 Kumārila, in his Sloka -vārttika, quotes this view: "Some held that [short], long and extra-long are in fact different sounds (varnāntaratvam evāhuh kecid dīrgha -plutādișu). "192 
6.13. Bhartrhari has developed further the philosophy of language, which is seen only in its infancy in the works of Kātyāyana and Patañjali. However, Bhartṛhari sometimes soars beyond the empirical grammatical conception of language. Bhartrhhari says that the real sound (sphota) in $/ \mathrm{a} /, / \overline{\mathrm{a}} /$ and $/ \overline{\mathrm{a}} 3 /$ is the same. 193 The duration-difference pertains to the primary manifesting sounds (prākrta-dhvani), and not to the real sound (sphota). However, the durationdifference of the primary manifesting sounds is imposed (upacaryate) on the real sound. The difference in speed is attributed to secondary manifesting sounds (vaikrta-dhvani), which are prolongations of the primary manifesting sounds. The difference of speed is not imposed on the real sound. Bhartrhari also notes that some thinkers identified the level of real sounds with what he considers to be primary manifesting sounds. In that case, the short, long and extralong sounds are different real sounds. This seems to be the view of Kātyāyana and, perhaps, of Pānini also.

On the level of empirical linguistics, however, Bhartrhari's views are not in any real contradiction with Kätyāyana. In fact, Bhartṛhari's real sound (sphota) stands on a supra-mundane level and is not a part of analytical grammar. The level of analytical grammar is reflected in Bhartrhari's primary manifesting sounds, whose distinctions of quantity are imposed on the timeless real sound. This imposition has a functional value in grammar. It shows that these features of quantity etc. are not distinctive on the supra-mundane level of real sounds, but are distinctive on the level of analytical grammar. On the other hand, the distinctions of speed, belonging to secondary manifesting sounds, are not imposed on the real sound. This shows that they are not distinctive for analytical grammar. Thus, there may be a difference between Bhartrhari and Kätyãyana on the level of sphota "real sounds, "but they fully agree on the fact that features such as quantity are basically distinctive in Pānini's grammar.

6.14. This procedure of Päninian homogeneous-representation radically differs from Kātyāyana's proposal for universalmention. In universal-mention, a term, by nature, stands 
for the type or universal, while Pänini lists the sounds and then states the rule P.1.1.69, whereby the sounds listed are terms standing both for themselves and sounds homogeneous with them. Thus, we have a basic division of sounds, i.e. a) sounds which are directly listed in the Siva-sūtras, and b) sounds which are represented by the listed sounds. Only the listed /a $-\mathrm{N} /$ sounds and consonants marked with /U/ stand for their homogeneous sounds, while the represented sounds (i.e. non $-/ \mathrm{a}-\mathrm{N} / \mathrm{sounds}$ ) are not capable of representing their homogeneous sounds. Thus, /a/ stands for all the eighteen homogeneous sounds, while $/ \bar{a} /$ stands for itself. Here "itself" naturally covers those varieties or instances which are totally identical in distinctive features with $/ \bar{a} /$. In a number of instances, Kātyāyana shows that the non-/a-N/ sounds in Pănini just stand for themselves. These are some of the cases:

[A] On P.1.1.1 (vroddhir ād-aic), Kātyāyana says that the marker $/ T\rangle$ added to $\overline{\bar{a}} /$ is necessary for the coverage of homogeneous varieties of the same quantity, since pitch is distinctive, and without $/ \mathrm{T} /, / \overline{\mathrm{a}} /$ would not cover varieties differing in pitch. 194

[B] The Siva -sūtra $/ \mathrm{a} /-/ \mathrm{i} /-/ \mathrm{u} /-\mathrm{N} /$ contains an open (vivrta) $7 \mathrm{a} /$. In P. 8.4.68 (a a), open $/ a /$ is replaced with a closed $/ a /$. The second $/ a /$ being a closed /a/ is not an /a -N / sound. Kātyāyana is afraid that this closed /a/ might not cover any homogeneous varieties. To resolve this problem, he proposes that $/ \mathrm{T} /$ should be added to this closed $/ \mathrm{a} /$, so that it can cover six short closed varieties. 195

[C] Kātyāyana points out that /āa in P. 7.2.84 (asțana $\bar{a}$ vibhaktau) which is a substitute for $/ \mathrm{n} /$ in a șțan is a non-/a-N/ sound and hence it cannot represent its nasal homogeneous varieties. Thus, there is no undesired possibility of $/ \mathrm{n} /$ being substituted by a nasal $/ \tilde{\bar{a}} / .196$

All these cases show that for Kātyāyana the non-/a-N / sounds in Pānini are incapable of representing their homogeneous sounds, and this is the result of the procedure of Vākyāparisamāpti. 
6.15. In these cases, Kātyāyana is not proposing a new theory of his own, but is trying to answer objections against Pănini by explaining Pāninini's own position. Even the addition of $/ \mathrm{T} /$ proposed in [C] above is in accordance with the procedure of Vākyāparisamäpti. Many of the Vārttikas of Kātyāyana are not codanās "objections" or "new injunctions," but are rather anvākhyānas, in Thieme's words, "explanation(s) of the purpose of Pānini's rule as given by a teacher to a student, who left to himself, might or might not have missed the point."197 For a historical insight into the Vārttikas of Kătyãyana, Thieme proposed the following:

The explanations said to be 'recited' by Kātyāyana are, of course, meant to be memorized by the students. They are part of the scholastic training. Yet, important as they are for the correct understanding of Pānini, they are routine answers of anonymous origin, they may even be imagined to go back to Pānini himself. Kātyāyana recites them because he did not invent but only repeats them as part of the exegetic tradition. They must, to say it again, be clearly distinguished from those vārttikas that contain a vacana, an original 'teaching,' where Kătyāyana places himself on the same level with Pānini and opposes or adds his own scientific formulation to that of the Asțādhyāyī. A vacana, too, is meant, of course, to be 'recited' by teacher and pupil, but it has a much higher dignity: in this instance, the teacher does not merely 'recite,' he 'speaks' as an individual, a self-thinking, creative scholar. 198

Kătyāyana's explanation of problems in Pānini's grammar on the basis of the procedure of vākyāparisamāpti seems to be a part of the routine exegetical tradition which precedes Kătyāyana, and may go back to Pānini himself. On the other hand, Kātyāyana's proposal of universal-mention or of splitting the internal effort of vowels from spirants belong to himself. 

CHAPTER VII

\section{PROBLEMS IN VĀKYĀPARISAMĀPTI}

\subsection{A TRADITIONAL APPROACH}

7.1.1. In the view of vākyāparisamāpti, P.1.1.69 does not apply to the shortforms /a-C/ and /ha-L/ in P.1.1.10, and hence the sounds denoted by these shortforms cannot further represent their homogeneous sounds. 199 This makes/a-C/ and /ha-L/ mutually exclusive classes and thereby avoids problems like / $\hat{\mathrm{s}} /$ being non-homogeneous with itself [ ref: Sec. 4.2-3] . But the following also results:

$$
\begin{aligned}
& {[1] \quad / \bar{a} / \text { and } / \bar{a} 3 / \text { are still homogeneous with } / \mathrm{h} / .} \\
& {[2] / / / \text { and } / \overline{1} 3 / \text { are still homogeneous with } / \hat{\mathrm{s}} / \dot{\mathrm{s}} / .} \\
& {[3] / \overline{\mathrm{r}} / \text { and } / \overline{\mathrm{r}} 3 / \text { are still homogeneous with } / \mathrm{s} / \mathrm{s} \text {. }}
\end{aligned}
$$

According to the Pāninian tradition, this is the ineveitable logical conclusion of the procedure of vākyāparisamāpti.

7.1.2. This has created many problems for the traditional grammarians. For instance, P.6.1.101 (akah savarne dïrghah) literally means: "Whan an $/ \mathrm{a}-\mathrm{K} /$ sound [i.e. $/ \mathrm{a} /$, $/ \mathrm{i} /, \mathrm{u} /, / \mathrm{r} /$ and $/ 1 / 1$ is followed by a homogeneous sound, both are replaced by a homogeneous long sound." By P.1.1.69, /a $-\mathrm{K} /$ stands for all the varieties of the denoted sounds. P.1.1.10 also applies to $/ \mathrm{a}-\mathrm{K} /$ sounds, so that it does not represent any consonants. 201 Let us see what happens in the example kumāri sete. Here $/ \bar{i} /$ is an $/ \mathrm{a}-\mathrm{K} /$ sound. It is represente by $/ \mathrm{i} /$ included in $/ \mathrm{a}-\mathrm{K} / \mathrm{s}$. Though by P.1.1.10, $/ \mathrm{i} /$ is not homogeneous with $/ \dot{\mathbf{s}} /, / \mathbf{i} /$ is still homogeneous with $/ \dot{s} /$. Thus, in kumārī śete, an $/ a-K /$ sound is followed by a homogeneous sound, and both $/ \bar{i} /$ and $/ \bar{s} /$ together would be replaced by $/ \bar{i} /$. So finally we might derive the undesirable form kumāryete*. Similarly, 
from kanyā hasati, we might derive the undesirable form kanyāsati*. Surprisingly, this point has not been noted by Kātyāyana and Patañjali .

Bhartrhari noticed this difficulty for the first time and answered it by relying on the continuation of the word aci in this rule. 202 With the addition of this word, P.6.1.101 means: "when a homogeneous /a-C/ sound follows." Though $/ \hat{\mathbf{s}} /$ is homogeneous with $/ \tilde{i} /$, it is not a homogeneous /a $-\mathrm{C} /$ sound, since $/ \mathrm{i} / \mathrm{in} / \mathrm{a}-\mathrm{C} / \mathrm{is}$ not homogeneous with $/ \hat{\mathrm{s}} /$ and will not represent $/ \hat{\mathrm{s}} /$. Looking at the text of the Aștāahyāyī, we find aci in P.6.1.77 (iko yan aci). The gap between P.6.1.77 and P.6.1.101 is too wide to justify continuation of aci, unless it is continued through all the intervening rules. The word aci does not continue through all of these intervening rules. This makes Bhartrhari's suggestion historically very doubtful. However, if it is accepted, it solves the problem in P.6.1.101. This solution has been followed by all the later commentators. 203 Bhațtoji Dikșita and Nāgeśa say that we need not continue aci in P.6.1.101, if we accept subclassification of vivrta "open."204 Otherwise, they approve Bhartrihari's proposal.

7. 1.3. Bhartrhari's solution does not solve all the problems. If $/ \bar{a} /$ and $/ \bar{r} /$ are homogeneous with $/ \mathrm{h} /$ and $/ \hat{\mathrm{s}} /$, is it possible that $/ \overline{\mathrm{a}} /$ and $/ \overline{\mathrm{i}} /$ could stand for $/ \mathrm{h} /$ and $/ \hat{\mathrm{s}} /$ ? This does not happen because, $/ \bar{a} /$ and $/ \bar{i} /$ are non $-/ \mathrm{a}-\mathrm{N} /$ sounds, and hence they cannot stand for any homogeneous sounds. Even $/ \overline{\mathbf{a}} \mathrm{T} /$ and $/ \overline{\mathrm{TT}} /$ cannot stand for $/ \mathrm{h} /$ and $/ \hat{\mathrm{s}} /$, because the marker $/ \mathrm{T} /$ enables a sound to stand for homogeneous sounds of the same quantity. Similarly, / $/$ / cannot stand for $/ \tilde{r} /$, because $/ \dot{s} /$ is a non $-/ a-N /$ sound, and it is not marked with $/ \mathrm{U} /$. The only loophole left is that $/ \mathrm{h} /$ is an $/ \mathrm{a}-\mathrm{N} /$ sound, and it would be able to stand for $/ \overline{\mathrm{a}} /$ and $/ \overline{\mathrm{a}} 3 /$.

7.1.4. The realization of the problem that $/ \mathrm{h} /$ is an $/ \mathrm{a}-\mathrm{N} /$ sound and that it might undesirably represent $/ \bar{a} /$ and $/ \bar{a} 3 /$ is seen in the commentaries on the Kâsika-vrtti. P.8.3.59 (ādeśa-pratyayayoh, in -koh from 57 ) says that $/ \mathrm{s} /$ is replaced by $/ s /$, if $/ s /$ is either a substitute or a part of an affix, and if it is preceded by $/ \mathrm{i}-\mathrm{N} /$ sounds or by $/ \mathrm{kU} /$ sounds (i. e. 
$/ \mathrm{k} /$ series of stops). The shortform $/ \mathrm{i}-\mathrm{N} /$ is formed with $/ \mathrm{N} /$ in $/ \mathrm{l}(\mathrm{a})-\mathrm{N} /$, and hence it covers $/ \mathrm{h} /$ which might stand for $/ \bar{a} /$ by P.1.1.69. The Kāśikā -vrtti, on P. 8.3.57 (inkoh), gives dãsyati as a counter example. This creates a prima facie problem, which is answered by the Nyāsa of Jinendrabuddhi as follows:

How is this counter-example justified, while $/ \mathrm{h} /$ included (in $/ \mathrm{i}-\mathrm{N} /$ ) stands for $/ \overrightarrow{\mathrm{a}} /$ by $\mathrm{P} .1 .1 .69$ ? The sound $/ \overline{\mathrm{a}} /$ is homogeneous with $/ \mathrm{h} /$, because they have the same point of articulation and internal effort. As the sounds $/ \mathrm{a} /, / \mathrm{kU} /(/ \mathrm{k} /$-ser̀ies $), / \mathrm{h} /$ and $/ \mathrm{h} /$ are produced in throat (kanthya), these two have the same point of articulation. As the internal effort of spirants and vowels is 'open,' their internal effort is also the same. Thus, by the rule P.8.3.57 (in-koh), the retroflex substitute $[/ \mathrm{s} /$ for $/ \mathrm{s} /]$ obtains [in dāsyati], because P.1.1.10 does not prohibit the designation 'homogeneous' [ to $/ \bar{a} /$ and $/ \mathbf{h} /]$. If this is the problem, there is no difficulty, because he (Pānini) uses [ the word vayasyāsu] in P.4.4.127 (vayasyāsu mūrdhno matup), where he does not change $/ \mathrm{s} /$ after $/ \bar{a} /$ to $/ \mathrm{s} /$. From this it is inferred that $/ \mathrm{h} /$ does not represent $/ \overline{\mathrm{a}} /$. Otherwise, he would not have made use of the form vayasyāsu. 205

Thus, in the view of the Nyāsa, $/ \mathrm{h} /$ and $/ \overline{\mathrm{a}} /$ are homogeneous, but as it can be inferred from Pānini's own usage, $/ \mathrm{h} /$ does not stand for $/ \bar{a} /$. The other commentary, Padamañjari of Haradatta, gives a different explanation:

Just as homogeneity of $/ \overline{1} /$ and $/ \dot{\mathbf{s}} /$ is not prohibited [by P.1.1.10], so also of $/ \bar{a} /$ and $/ \mathrm{h} /$. So what? Would there be a possibility of the substitution of $/ \mathrm{s} /$, because $/ \mathrm{h} /$ would stand for $/ \overline{\mathrm{a}} / \mathrm{?}$ ? There is no problem. The sound $/ \mathrm{h} /$ is vivrta 'open,' but $/ \bar{a} /$ is vivrta tara 'more open.' $\cdots$ This justifies [Pānini's] usages like vaya syāsu. "206

While Patañjali would have $/ \mathrm{h} /$ to be slightly open and $/ \overline{\mathrm{a}} /$ 
to be open, Haradatta has $/ \mathrm{h} /$ open and $/ \bar{a} /$ more open. The effect is the same. This works well, but is obviously unPāninian, since it would make P.1.1.10 without purpose.

7.1.5. Then comes Bhațtoji Dikșita, whose subtle analysis brings out more problems due to homogeneity of $/ \mathrm{h} /$ and $/ \bar{a} /$. He gives about ten examples where this might create problems. $207 \mathrm{He}$ also goes a step further and points out that $/ \mathrm{h} /$ would also stand for $/ \overline{\mathrm{a}} 3 /$ and would create problems in some cases. 208 In his Śabda-kaustubha, Bhatțoji discusses at length various solutions to this problem. Along with the solutions of universal-mention and subclassification of openness, he proposed the following new solution: In the view of vākyāparisamāpti, we have to imagine an insertion of $/ \bar{a} /$ in P.1.1.10. By combining $/ \bar{a} /$ and $/ \bar{a} 3 /$, we get $/ \bar{a} /$. Then we split nājjhalau as na $\bar{a} c$-halau, where $/ \bar{a} c /$ is to be explained as $\overline{\bar{a}} /+/ \bar{a} 3 /+\overline{a C} T$. Thus this rule specifically denies homogeneity of $/ \bar{a} /$ and $/ \bar{a} 3 /$ with consonants, and gets rid of all the problems. 209 Bhattoji mentions P.3.3.163 (kāla-samaya -velāsu tumun) where the term velāsu occurs. If $/ \bar{a} / \overline{\text { and } / \mathrm{h} /}$ were homogeneous for Pạnini, he would have used the expression velāsu*. Bhatțoji takes this usage as a sanction for his insertion of $/ \overline{\mathbf{a}} /$ in P.1.1.10.210

7.1.6. Later grammarians like Hari Dikșita and Nāgeśa are faced with evaluating Bhatțoji's suggestion. Both of them realize that they have two alternatives. 211 We may either have an independent rule saying that, in Pānini, $/ \bar{a} /$ and $/ \mathrm{h} /$ are not mutually homogeneous, or we may accept Bhatțoji's insertion of $/ \bar{a} /$ in P.1.1.10. With their typical traditional outlook, they feel that adding a rule to Pannini's grammar involves the fault of prolixity, while Bhattoji's explanation has the merit of brevity.

Actually, P.1.1.10 could be interpreted as Bhatțoji does by following the normal rules of sandhi. But this interpretation is still far from being historically valid. However, we have to accept Bhattoji's inference from velāsu in P. 3.3.163 that Pānini did not want $/ \mathrm{h} /$ to represent $\overline{\mathrm{a}} /$. Bhattoji's suggestion solves the problems pointed out by him, but then the whole picture of homogeneity still remains very much distorted. Neither Bhartṛhari nor Jinendrabuddhi 
and Bhattoji can avoid homogeneity of $/ \tilde{i} /$ with $/ \hat{s} /$ etc. All that they do is to try to avoid practical problems. With all respect to these great grammarians, one still feels doubtful, if this distorted picture of homogeneity was intended by Pānini. Or might there be another interpretation which is lost to us?

7.1.7. Looking at the problem from within the Pāninian tradition, this is what we can say. The procedure of vākyāparisamāpti was the procedure of Pānini. It was so realized by Kātyāyana and was utilized to answer many objections to Pânini's formulations. This procedure apparently did not pose any problems of its own either for Kätyãyana or for Patanjali, and they show no awareness of any loopholes in it.

This, however, does not mean that for Pānini, Kātyāyana and Patañjali, it was fine if, for instance, /h/ represented $/ \bar{a} /$. Jinendrabuddhi and Bhattoji have given valid inferences from Pānini's own usages to the contrary. In Kātyāyana's theory of universal-mention, long vowels

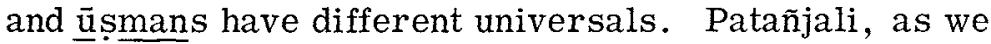
have seen, subclassifies open-ness and avoids homogeneity of vowels with consonants. Patañjali makes a clear statement: "The ū șans and / $\mathrm{r} /$ have no homogeneous sounds [other than themselves] . "212 K. V. Abhyankar comments:

This is an axiomatic assertion of the Bhāsyakāra, based on a careful observation and scrutiny of words and letters used in the language. Grammar is to follow language, language is not to follow grammar. 213

This comment implies that Patañjali's statement, though true, does not follow from Pānini's rules. Whether this is true can only be decided if we ever unearth a preKātyāyana commentary on Pānini .

\subsection{A NEW APPROACH}

7.2.1. The discussion in the previous section puts us into a serious problem. The silence of the great Panninians on 
problems of vākyāparisamāpti may be an indication that for them there were no problems with P.1.1.10, and that there was probably some normal explanation of P.1.1.10. Unfortunately, the works of Kätyāyana and Patañjali deal mainly with problems in Pănini's grammar, and they did not concern themselves with those rules which to them were perfectly normal and without problems. This task was left to the conventional Vrttis. Some of these commentaries did exist even before Patañjali, but they are now lost to us. The first rule-to-rule commentary that is available to us is the Kāsikā -vrtti, which in some respects preserves the older traditions, 214 but is itself a very late work, and is influenced by the grammar of Candragomin. 215 It is quite possible that many normal explanations were already lost by the time of the Kāsikã -vrttí.

7.2.2. Let us look at the modern interpretations of P.1.1.10. The earliest interpretation of P.1.1.9 and P.1.1.10 that we have goes back to Colebrook:

P.1.1.9: Letters articulated near the same organ of speech and with the same aperture for the voice, are homogeneous; P.1.1.10: but a vowel and a consonant are not so. 216

S. C. Vasu translates P.1.1.10 as follows:

There is however no homogeneity between vowels and consonants, though their place and effort be equal. 217

Louis Renou's translation runs as:

Les phonèmes 'a...c' (sles voyelles) et 'ha...l' ( =les consonnes) (même étant dans les conditions requises sous 9) ne sont pas (homophones entre elles). 218

Otto Böhtlingk renders P.1.1.10 as: 
Ein Vocal (ac) und ein Consonant (hal) sind einander nicht homogen. 219

No scholar says anything as to how the meaning that he gives is derived, though the intuitively given meaning is what the rule ought to teach. Instead of just depending on intuition, the Panninian grammarians tried to give their own explanations. We may disagree with their explanations, but it at least shows that there lies a rule which still needs a rational explanation.

7.2.3. Another partial hypothesis about P.1.1.10 has occurred to me. We shall briefly discuss it here. The argument is as follows. If $\mathrm{a}=\mathrm{b}$ and $\mathrm{a} \neq \mathrm{c}$, then obviously $\mathrm{b} \neq \mathrm{c}$. Similarly, if $/ \mathrm{a} /$ is homogeneous with $/ \overline{\mathbf{a}} /$, and is not homogeneous with $/ \mathrm{h} /$, then it should naturally follow that $/ \bar{a} /$ is not homogeneous with $/ \mathrm{h} /$.

On the face of it, this seems quite sound. However, this is not exactly the case with Pannini's rules. By P.1.1.9, we get the following three statements:

[1] $/ \mathrm{a} /$ is homogeneous with $/ \overline{\mathrm{a}} /$.

[2] $/ a /$ is homogeneous with $/ h /$.

[3] $/ \bar{a} /$ is homogeneous with $/ \mathrm{h} /$.

These statements are quite independent of each other and each case fulfils the conditions of homogeneity laid down in P.1.1.9. The statement [3] is not deduced from [1] and [2], but stands on its own grounds. Now by P.1.1.10, we get denial of the statement [2]. Since the other two statements are in no way dependent on [2], the denial of [2] cannot in any way lead to the denial of either [1] or [3]. The statements [1] and [3] still fulfill the conditions of P.1.1.9, and there is nothing in Pānini's rules to stop [3] from being true, except of course the inferences of Jinendrabuddhi and Bhattoji. Though such inferences have a definite practical value, the system as such still remains faulty on account of its loopholes.

7.2.4. In what follows, an explanation is offered, which by 
no means is claimed to be the historical explanation, but, in a modest way, to be an explanation which is more probable than the others seen before.

Before going to P.1.1.10, let us go back to P.1.3.3 (hal-antyam). The circularity in this rule can be removed only by reading the rule twice and giving a different interpretation to each reading. This case has been discussed in detail in Sec. 5.3. It has also been critically studied by Thieme. 220 This solution goes back to Kātyãyana, and it is quite possible that it even precedes him.

The same procedure may be extended to P.1.1.10. This removes all the problems in the procedure of vākyāparisamãpti. For the sake of interpretation, the order of rules should be as follows:

$[1]$ na ac-halau P.1.1.10A.
$[2]$ P. $\frac{1.1 .69}{13]}$ P.1.1.10B.

If interpreted in this order, the second reading, i.e. P.1.1.10B, gives us the final meaning of the rule, just as the second reading of P.1.3.3 gives its final meaning.

P.1.1.10A means: "The /a-C/ sounds, as listed in the Siva-sütras, are not homogeneous with /ha-L/ sounds." With this we interpret P.1.1.69: "The /a-N/ sounds and sounds marked with $/ \mathrm{U} /$ stand for their homogeneous sounds, unless they are affixes." By this rule, /a/ can stand for all its homogeneous sounds, but not for $/ \mathrm{h} /$, since P.1.1.10A has already denied homogeneity of $/ \mathrm{a} /$ and $/ \mathrm{h} /$. We then use P.1.1.69 to interpret P.1.1.10B, which then means: "Sounds represented by / $\mathrm{A}-\mathrm{C} / \mathrm{and} / \mathrm{ha}-\mathrm{L} / \mathrm{sound}$ are not mutually homogeneous." Here, /a/ in $/ a-C /$ stands for all varieties of $/ \mathrm{a} /$, including $/ \tilde{\mathrm{a}} /$, but not for $/ \mathrm{h} /$. Thus, finally, P.1.1.10B means to say: "No vowels are homogeneous with any consonants." In this interpretation, the picture of homogeneity becomes straightened out.

7.2.6. Though we may not be able to say that this is the 
historically true interpretation, this very procedure seems to have been implicitly followed by all the modern scholars, whose translations are given earlier. All of them clearly interpret P.1.1.10 as denying homogeneity between the classes of all vowels and all consonants. These classes cannot be obtained without applying P.1.1.69 to P.1.1.10. However, if we apply P.1.1.69 to P.1.1.10 before denying homogeneity of /a $-\mathrm{C} /$ sounds with /ha $-\mathrm{L} /$ sounds, then the classes represented by /a-C/ and / ha-L/ overlap. None of the scholars intends such overlapping. This means they implicitly applied P.1.1.69 to P.1.1.10 after non-homogeneity of $/ \mathrm{a}-\mathrm{C} /$ and /ha-L/ sounds was already established. Thus it seems that these scholars implicitly considered P.1.1.10 on two different levels, and without ever clarifying their intuition, they arrived at the right conclusion. An interpretation similar to this might have existed in the early centuries of Pāninian interpretation. However, no historical claims can be made for lack of any real substantiating evidence. 



\section{CHAPTER VIII}

\section{RESTRICTIONS ON \\ HOMOGENEOUS-REPRESENTATION}

8.1. In this chapter, we shall discuss the question of the interpretation of the condition apratyayah in P.1.1.69 and certain problems related with $\overline{P .1 .1 .70}$. I have devoted a long article to these problems. However, as these considerations are very important in understanding the function and implementation of homogeneity in Pãnini's rules, we shall discuss here the main arguments. For the details, the reader is referred to the original article. ["Pāninian Procedure of Taparakarana: A Historical Investigation," Zeitschrift für vergleichende Sprach-forschung, Band 86, Heft 2, 1972, pp. 207-254.]

8.2. By P.1.1.69, the non-affixal sounds denoted by the shortforms $/ \mathrm{a}-\mathrm{N} /$ and sounds marked with $/ \mathrm{U} /$ stand for themselves and their homogeneous sounds. The expression apratyayah "non-affixal" occurs in two other rules of Pānini and five vārttikas of Kātyāyana in the sense of "non-affix" or "excluding affixes.."221 Kātyāyana has no doubt about its meaning, nor any objections to raise.

Patañjali, however, reinterprets P.1.1.69 and derives a general maxim: bhāvyamānena savarnānām grahanam na "There is no representation of homogeneous sounds by a sound which is itself introduced by a rule." [MB, Vo. I, Sec. I, p. 370-1.] Henceforth we shall refer to this maxim as Maxim [1] . Patañjali tries to show that Pănini could not have meant "affix" by the term pratyaya in P.1.1.69. An affix is a meaning-bearing unit and it will not represent its homogeneous sounds, simply because they will not convey the same meaning. Then, a prima facie solution is given to this question. Some sounds are directly known (pratiyante), while other homogeneous sounds are made known or 
represented (pratyäyyante) by the sounds which are directly known. Thus, apratyayah may mean that the represented sounds do not represent their homogeneous sounds. But Pāninini need not say this, since a long / $/ \bar{a} /$ would not represent the short variety, because it requires an additional effort for its pronounciation. It also may not represent the extralong varieties, because the long variety itself is a non/a $-\mathrm{N} /$ sound. Thus the condition apratyayah apparently seems to be redundant and hence Patañjali takes it to be an indication (jñāpaka) of the above mentioned Maxim [1] .

The term bhāvyamāna in the Maxim [1] is rendered as "introduced elements." If a rule is: "If preceded by $\mathrm{A}$ and followed by $\underline{\mathrm{D}}, \underline{\mathrm{B}}$ is replaced by $\underline{\mathrm{C}}, "$ then $\underline{\mathrm{C}}$ is the introduced element, while $\underline{A}, \underline{B}$ and $\underline{D}$ are not introduced elements. They are conditioning elements and substituendum. In Patañjali's argument, the term "introduced elements" refers to affixes, substitutes and augments. The later term for bhāvyamāna is vidhiyamāna.

8.3. Kaiyata on this discussion almost misunderstands Patañjali. For Patañjali, the condition apratyayah does not mean "non-introduced elements, " but is simply an indication of the Maxim [1] . Kaiyata says that pratyaya means vidhīyamāna, because the verbs pratiyate and vidhiyate have the same meaning [MB-P, Vol. I, Sec. I, p. 370; SK, p. 3] . Nāgeśa points out that this is quite untenable:

In fact, the literal meaning of the Bhāsya is that Pānini implies the Maxim [1], by allowing a portion [of the introduced elements, namely the affixes, to be without the capacity of homogeneous-representation]. What Kaiyața says is doubtful, since pratiyate is not found used in the meaning of vidhiyate. [MB-P-U, Vol. I, Sec. I, p. 371.]

8.4. Patañjali's argument deviates considerably from Pānini's original scheme, and the Maxim [1] is Patañjali's addition. We shall see later that this suggestion might actually be pre-Patañjali, but post-Kātyāyana. Patañjali holds that in Pānini's rules, substitutes ( 
(āgama) along with affixes (pratyaya) lack the capacity to represent their homogeneous sounds. However, it is doubtful if this was Pannini's own intention, since he uses the marker $/ \mathrm{T} /$ with about fifty substitutes 222 in restrictive and prescriptive functions. As the word pratyaya simply stands for affixes, P.1.1.69 must be effective with all non-affixal /a $-\mathrm{N} /$ sounds, including substitutes and augments. This is the understanding of the Kāsika $\sim \underline{v} \underline{\text { rtti. }} .223$ So is Louis Renou's rendition:

Les phonemes /'a-n'/ (=voyelles et semi-voyelles) et ceus à exposant $/ \mathrm{u} /$--désignent les homophones (en même temps que leur forme propre), excepté si ce sont des affixes. 224

8.5. These two views about apratyayah in P.1.1.69 affect the interpretation of P.1.1.70 (taparas tat-kālasya). There are two major interpretations of P.1.1. $\overline{70}$ :

Interpretation $[\mathrm{A}]:$ If the term /a $-\mathrm{N} /$ in P. 1.1.69 is carried over into P.1.1.70, then it comes to mean that $/ \mathrm{a}-\mathrm{N} /$ sounds followed by $/ \mathrm{T} /$ represent the homogeneous varieties of the same quantity. Here, as in P.1.1.69, the term /a-N/ stands only for the sounds as they are listed in the Siva-sütras. Thus, $/ \mathrm{T} /$ has restrictive function (niyāmakatva) with respect to $/ \mathrm{a}-\mathrm{N} / \mathrm{sounds}$, but has no function with respect to non $-/ a-N /$ sounds. Since Pānini uses $/ \mathrm{T} /$ with a large number of non $-/ \mathrm{a}-\mathrm{N} /$ sounds, 225 this interpretation appears insufficient.

Interpretation [B] : The term /a $-\mathrm{N} /$ in P.1.1.69 is not continued into P.1.1.70. Thus, P.1.1.70 means that any vowel followed by the marker $/ \mathrm{T} /$ represents homogeneous sounds of the same quantity. In the case of $/ \mathrm{a}-\mathrm{N} /$ vowels, this rule becomes restrictive (niyāmaka), while in the case of non/a $-\mathrm{N} /$ sounds, the rule becomes presecriptive (vidhāyaka). Without $/ \mathrm{T} /$, a non $-/ \mathrm{a}-\mathrm{N} /$ sound can stand only for itself, and cannot cover other varieties of the same quantity. 
Of these two interpretations of P.1.1.70, [B] seems to be the historically Panninian interpretation, since this alone explains the cases of non-/a-N/ sounds with the marker /T/ in Pānini's rules.

8.6. Taking into account the major divergent interpretations, it is possible to discern two prominent views concerning the function of the marker $/ \mathrm{T} /$.

View $[\mathrm{A}]$ : apratyayah $=$ "non-introduced elements." The introduced elements, i.e. affixes, substitutes and augments do not represent their homogeneous sounds, and hence there is no need to attach a restrictive marker $/ \mathrm{T} /$ to these elements. In the case of non-introduced elements, namely conditioning elements, the /a-N/ and non $-/ \mathrm{a}-\mathrm{N} / \mathrm{sounds}$ with the marker $/ \mathrm{T} / \mathrm{stand}$ for homogeneous sounds of the same quantity.

View [B] : apratyayah = "non-affixal." Excepting the affixes, all the $/ \mathrm{a}-\mathrm{N} / \mathrm{sound}$ as given in the Siva-sūtras are capable of representing their homogeneous sounds by P.1.1.69. The /a $-\mathrm{N} /$ and non/a $-\mathrm{N} /$ sounds with $/ \mathrm{T} /$ stand for homogeneous sounds of the same quantity. Without $/ \mathrm{T} /, / \mathrm{a}-\mathrm{N} / \mathrm{sounds}$ represent all their homogeneous sounds, while the non-/a-N/ sounds represent only themselves.

Of these two views, the View [A] is held by almost the whole tradition of Päninians beginning with Patañjali, or rather with Vyādi, while the View [B] is what Pānini must have intended and is so understood by Kātyāyana. This has been conclusively demonstrated after studying every rule with $/ \mathrm{T} /$, in Deshpande [1972] .

8. 7. If we accept the View [A] or the Maxim [1], then no substitutes are capable of any representation, since every substitute is an introduced element, and hence there is no need to attach the marker $/ \mathrm{T} /$ to restrict homogeneous representation. Patañjali [MB, Vol. I, Sec. I, p. 370] considers the Maxim [1] to be necessary to avoid 
representation of homogeneous sounds in P.2.3.3 (idama is ). 226 However, there are several arguments which go against Patañjali's view. There are about fifty examples of substitutes with $/ \mathrm{T} /$ in Pānini's rules, against only about twenty cases of vocalic substitutes without $/ T / .227$ These statistics themselves stand as a proof for the unhistoricity of the Maxim [1] . Pănini could not have attached the marker $/ \mathrm{T} /$ to so many substitutes without any significance. The significance of $/ \mathrm{T} /$ with substitutes has to be explained according to P.1.1.70, and not according to P.6.1.185 (tit svaritam), since they are not affixes. 228 in a number of rules such as P. 7.4.66 (ur at), 229 it is clear that the substituenda are long vowels, while the substitutes are short vowels, and Pānini rightly thinks that, in the absence of $/ \mathrm{T} /$, the non-affixal substitutes will represent their homogeneous sounds. Then only the long vowels will be effected as the substitutes by P.1.1.50 (sthāne'ntaratamah) 'In the place [of a substituendum] a most-similar substitute is effected." Thus, the marker $/ \mathrm{T} /$ has a positive restrictive function with these substitutes. Sometimes, even the Kāsilkāvrtti accepts this restrictive function of the marker $/ \mathrm{T} /$ with substitutes. 230

8.8. On P. 7.2.84 (asțana ā vibhaktau), Kātyãyana says: "Tn the case of [the substitution of] $/ \bar{a} /$ for [ the final $/ \mathrm{n} /$ of] astan, jan etc., pathin and mathin, there is a possibility of a nasal $[\overline{\bar{a}} /$ being substituted], because it is most similar [ to the nasal substituendum $/ \mathrm{n} /$ ] ." 231 This objection is answered as follows: "[ The desired result that only a nonnasal $/ \bar{a} /$ will be substituted for nasal $/ \mathrm{n} /]$ is achieved, since [ the substitute $/ \bar{a} /$ is] a non $-/ a-N /$ sound, [and hence it does not represent any homogeneous varieties]. "232 This shows that, for Kătyāyana, a substitute does represent its homogeneous sounds, if it is an $/ \mathrm{a}-\mathrm{N} / \mathrm{sound}$. This shows that the Maxim [1] is of post-Kätyäyana origin. 233 Kätyāyana himself uses $/ T /$ in his vārttikas with substitutes. For instance, $/ \mathrm{T} /$ is attached to the substitute $/ \mathrm{i} /$ in vt 6 on P.7.3.1, (vahinarasyed-vacanam), and to the substitute $/ \overline{1} /$ in vt 1 on P.8.2.17, (id rathinah).

8.9. Patañjali accepts the Maxim [1] first, and then to 
explain a single rule, he has to introduce another maxim, henceforth Maxim [2], which runs as: bhāvyamāno'py ukārah savarnān grhnāti: "An introduce $\bar{d} / \mathrm{u} /$ sound also represents its homogeneous sounds. "234 This is an exception to Maxim [1] . Once the Maxim [1] is accepted, then /T/ attached to $/ \mathrm{u} /$ in rules such as P.6.1.131 (diva ut) and P.6.1.111 (rta ut) becomes technically redundant. This has been taken as an indication by Patañjali and later grammarians for Maxim [2]. Then it is used to explain that the substitute $\mathrm{u} /$ in P.7.2.80 (adaso'ser dād u do mah) is without $/ \mathrm{T} /$ and hence it desirably represents its homogeneous sounds.

All this deductive logic sounds very convincing, if one accepts validity of Maxim [1] . The unhistoricity of that maxim has already been pointed out. If an occurrence of $/ \mathrm{T} /$ with an introduced $/ \mathrm{u} /$ indicates that an introduced $/ \mathrm{u} /$ can represent its homogeneous sounds, then by the same line of argument, the occurrence of $/ \mathrm{T} /$ with introduced $/ \mathrm{a} /$, $/ \mathrm{i} /, / \mathrm{r} /, / \overline{\mathrm{a}} /, / \overline{\mathrm{i}} /, / \overline{\mathrm{u}} /, / \mathrm{e} /, / \mathrm{o} /$ and $/ \mathrm{au} /$, in Pānini's rules, 235 should also indicate that these also represent their homogeneous sounds. It is a fact that Pānini uses / T/ with all these introduced sounds. This cuts at the very root of Maxim [1] . Similarly, if one accepts Maxim [2] , it creates very intricate problems which are neither discussed nor solved by Patañjali. 236

Once the View [B] is accepted as truly the Pãninian view, all the difficulties disappear. For Paninini, the /a-N/ substitutes are capable of representing their homogeneous sounds, as they are non-affixes. Similarly, the marker $/ \mathrm{T} /$ with substitutes has its normal restrictive and prescriptive functions. In the rule P.6.1.131 (diva ut), Pannini attaches $/ \mathrm{T} /$ to $/ \mathrm{u} /$, since only short $/ \mathrm{u} /$ is intended to be the substi tute. In P.7.2.80 (adaso'ser dād u do mah), he does not attach the marker $\overline{\mathrm{T} / \text { to }} \mathrm{/ \textrm {u }}$, since representation of long $/ \overline{\mathrm{u}} /$ is desired. There is nothing exceptional about this rule.

8. 10. There is a clear possibility that these two maxims may in fact belong to pre-Patañjali times. Maxim [1] is identical with Maxim $30^{237}$ and Maxim [2] is identical with Maxim $31^{238}$ in a text called Paribhāsā-sũcana, which is 
ascribed to Vyādi. According to the tradition, Vyādi is the first author on the paribhāsās "maxims." The style of this work is very similar to the Mahäbhāșya, but it never refers to Patañjali. This would be strange if Vyädi were posterior to Patañjali. We can certainly agree with K. V. Abhyankar when he argues that Vyādi, the author of the Paribhāsā-sūcana, is not posterior to Patañjali. 239 However, K. V. Abhyankar also regards this Vyāụi to be prior to Kātyāyana. Kātyāyana certainly refers to a grammarian named Vyădi. 240 But the author of the two maxims could not be pre-Kātyāyana, since there is no trace of these maxims in the vārttikas of Kātyāyana, and Kātyāyana's explanations clearly go against them. 241 It is possible that there were several persons named Vyädi.

8.11. That Patañjali's innovations are historically un-Paninian does not deprive him of his significant contribution which lies in his attempts to bring uniformity and simplicity of description in Pāninin's grammar. Representation of homogeneous sounds is not at all needed in any of the rules prescribing affixes, augments and substitutes, except in P. 7.2.80. On the other hand, Pānini has to use the marker $/ \mathrm{T} /$ to stop such representation in many cases. This prompts Patañjali to make Pānini's system more uniform. He almost suggests that $/ \mathrm{T} /$ is not necessary after any substitutes, and it could be eliminated, if we say that substitutes do not represent any homogeneous sounds. Such representation is needed only in one rule. If varieties differing in pitch, accent etc. are needed, they can be obtained by considering these features to be non-distinctive.

However, a critical distinction must be made between any attempts of simplifying Pāninian procedures and those of understanding them as they stand in their own right. Worth noting is S. D. Joshi's remark:

This will prevent us from committing the same mistake which was made by Patañjali and the commentators following after him, when they read later developed theories into Pānini and Patañjali respectively. 242 
Patañjali's suggestion was certainly valuable as a reform in Panini's grammar. Some of the later systems like JainendraVyākarana follow Patañjali's suggestion and incorporate it into their rules. [ref: N. 358.] 


\section{VYĀDI ON \\ HOMOGENEOUS-REPRESENTATION}

9.1. The name Vyādi is more known, in the Pāninian tradition, for the now lost magnificent Samgraha, an encyclopedic work on grammar, than for the Paribhāșā-sūcana, a compendium of grammatical maxims, which is more-over similar to the well known Paribhāsenduśekhara of Nāgeśa. The great antiquity of this work, its probable pre-Patañjali date, increases its importance for the history of Pāninian interpretation. As we have already seen, this work is probably post-Kātyāyana in origin, or at least parts of it are of post-Kātyāyana origin. This historical place of Vyādi's Paribhāșāsūcana enhances the value of its comments on homogeneity and its function in Pānini's grammar.

9.2. The Maxim 55 in this text runs as: udit sva-vargam eva grhnāti, na savarna-mātram: "A sound marked with $\overline{\mathrm{U}} / \mathrm{stan} \overline{\mathrm{ds}}$ only for the members of its varga 'group of homorganic stops,' and not for all the homogeneous sounds."243 Vyădi's commentary on this maxim gives the reasoning behind this statement:

A sound marked with $/ \mathrm{U} /$ stands only for its varga, and not for all its homogeneous sounds. How is this known? [We know this], because he [Pānini] independently mentions $/ \mathrm{s} /$ in the rule P.1.3.4 (na vibhaktau tu- $-\underline{s}-\underline{m a}$ ), while the mention of $/ \mathrm{tU} /$ would have been sufficient [to include /s/] . What is the purpose in indicating this [maxim] ? In the rule P.8.2.30 (coh kuh), the mention of $/ \mathrm{cU} /$ does not cover $/ \hat{\mathrm{s}} /$, and hence $[/ \hat{\mathrm{s}} /]$ does not happen [ to undergo the substitution] by $/ \mathrm{kU} /$ sounds. Thus, the correct form vid is derived. 244 
This statement of Vyādi needs to be carefully analysed in order to get at its implications. It means to say that unless we restrict a sound marked with $/ \mathrm{U} /$ to stand only for its varga, it will stand for all its homogeneous sounds. As Vyādi's examples indicate, /tU/ might cover /s/, and /cU/ might cover $/ \hat{s} /$. This implies that Vyādi does not want $/ \mathrm{tU} /$ and /cU/ to stand for $/ \mathrm{s} /$ and $/ \hat{\mathrm{s}} / \mathrm{respectively,} \mathrm{but,}$ according to him, by Pānini's definition of homogeneity, $/ \mathrm{t} /$ and $/ \mathrm{c} /$ are respectively homogeneous with $/ \mathrm{s} /$ and $/ \hat{s} /$. No other grammarian in the tradition ever suspected that P. 1.1 .9 could lead to such homogeneity of $/ t /$ and $/ \mathrm{s} /$, and $/ \mathrm{c} /$ and $/ \dot{\mathrm{s}} /$.

9.3. According to Vyădi, however, P.1.1.9 somehow leads to homogeneity of $/ \mathrm{t} /$ and $/ \mathrm{s} /, / \mathrm{c} /$ and $/ \hat{\mathrm{s}} /$. The internal effort of $/ t /$ and $/ c /$ is, according to all the traditions, sprsța "with contact." Depending on the interpretation we accept, /s/ and /s/ are either vivrta "open" or issad-vivrta "slightly with a gap, slightly open." Thus, $/ \mathrm{t} / \mathrm{and} / \mathrm{c} /$ differ from $/ \mathrm{s} /$ and $/ \hat{\mathrm{s}} /$, in respect of internal effort. They, however, share the same point of articulation. Thus, $/ \mathrm{t} /$ and $/ \mathrm{s} /$ are dental, while $/ \mathrm{c} /$ and $/ \mathrm{s} /$ are palatal.

This leaves us with only two alternatives: either, [A] Vyādi considered that P.1.1.9 only requires two sounds to have the same point of articulation, or

[B] for him, stops and spirants had the same internal effort.

The term àsya-prayatna in later days did only stand for internal efforts, but there is no conceivable way to interpret it to mean only sthāna: "point of articulation." Thus, the alternative [A] cannot be right as a correct description of the Pāninian conception of homogeneity. The alternative [B] also has no support either in the Pāninian tradition or elsewhere. 245

9. 4. Patañjali does not mention this maxim of Vyādi. In the later tradition of Paribhășa- -works, three authors have commented on this maxim. The reading in Siradeva's Brhat-paribhāsā $-v$ r.tti is somewhat different from Vyādi's reading: udit savarnaim grhnāti, na savarna-mātram: 
"A sound marked with /U/ stands only for its homogeneous sounds, but not for all homogeneous sounds."246 On the face of it, this does not make any sense. However, Siradeva's explanation is worth noting:

By P.1.1.69, a sound marked with $/ U /$ stands only for those homogeneous sounds, which share [the same] point of articulation and internal effort, and not for all homogeneous sounds. Thus, in the rule P.8.2.30 (coh kuh), the mention of $/ \mathrm{kU} /$ does not include $/ \mathrm{h} /$. The indication [ for this maxim] is provided by the [ separate] mention of $/ \mathrm{s} /$, in spite of that of $/ \mathrm{tU} /$, in P. 1.3.4 (na vibhaktau tu-s-māh). This fact, which actually follows naturally is explained through an indication (jñāpaka), for the sake of easy comprehension. 247

Like Vyädi's work, Sīradeva is also ambiguous as to what conception of homogeneity is being rejected. The examples of Sīradeva are parallel to Vyādi's examples.

9.5. Haribhāskara Agnihotrin has the same reading as Siradeva, but his explanation goes a step ahead:

A sound marked with $/ \mathrm{U} /$, by P.1.1.69, stands only for those homogeneous sounds, which are identical with respect to the point of articulation and internal effort, and not for all those homogeneous sounds which only share the same point of articulation. [This is established either] by the indication of the separate mention of $/ \mathrm{s} /$, along with $/ \mathrm{tU} /$, in P.1.3.4, or by the fact that P.1.1.69 teaches the designation 'homogeneous' only of a sound which shares the [same] point of articulation and internal effort. 248

Thus, the wrong notion of homogeneity, according to Haribhāskara Agnihotrin, is conditioned only by identity of the point of articulation, but he does not think that it is an interpretation of P.1.1.69. Thus, this notion of homogeneity as being identical with the notion of sasthāna "homorganic, with the same point of articulation" is of some 
non-Pāninian origin. It is possible that some grammarians before Vyāọi tried to bring this notion into Pānini's grammar, and that Vyädi's maxim was an attempt to prohibit application of such a notion of homogeneity. Within the Pāninian tradition, however, we do not need this maxim.

9.6. Nilakantha Dikșita gives the final blow to this maxim. He gives the same interpretation, but includes it among those maxims, which are classed as spurious and baseless. This is what he says:

Since this maxim is not seen in the Mahăbhāsya, and since the designation 'homogeneous' is made [by P.1.1.69] of only those sounds which are qualified [by both, the same point of articulation and internal effort], this [maxim] is spurious. 249

With all respect for Vyādi's name, we must agree with Nilakanțha Dikșita's assessment. 
PART TWO

NON-PANNINIAN TRADITIONS 



\section{PRĀTIŚĀKHYAS ON SAVARNA}

10.1. In the intitial stages of Indological research, Martin Haug arrived at the conclusion that the Sikșās are decidedly older than the Prātišalkhyas, and that the doctrines contained in the former were incorporated and further developed in the latter. 250 A. C. Burnell agrees with Haug and further says: "The Śiksāa s and Prātiśākhyas represent, so far, one side of the oldest form of the Aindra Grammar --the phonetic analysis of the language. "251 These scholars held that the views expressed in these texts preceded Pānini's grammar, which is supposed to have superceded the now lost Aindra School of Grammar.

Franz Kielhorn, with ample new evidence, proved conclusively that the Sikșās that have come down to us are certainly posterior to the Prātiśakkhyas. 252 He is not ready to consider these texts as either pre-Pāninian or productions of a school of grammarians. 253 Paul Thieme rightly accepts a high antiquity of the branch of the Siksa literature, but as far as the Siksa texts available to us are concerned, his views agree with those of Kielhorn. Thieme says: "They are all of them, young, elaborations of the definitions laid down in the Prātišâkhyas. "254 This prompts us to consider the conception of savarna in the Prâtišākhyas, before passing on to the Śiksâa and other non-Pāninian systems of grammar. Without delving into the debatable question of the relative chronology of the Prātiśākhyas, we shall briefly study their conception of savarna, and its implementation. 255 The question whether the Prātiśăkhyas are pre-Pāninian or post-Pāninian is still highly debated, and yet there is no doubt that the Prātiśākhyas do represent a grammatical tradition, which is certainly pre-Pāninian. 


\subsection{THE RGVEDA-PRĀTIŚĀKHYA}

10.2.1. The RPr considers the long and short corresponding vowels $[$ e.g. $\overline{\mathrm{a} /}, / \overline{\mathrm{a}} / ; / \mathrm{i} /, / \overline{\mathrm{i}} / ; / \mathrm{u} /, / \overline{\mathrm{u}} / ; / \mathrm{r} /, / \overline{\mathrm{r}} /]$ to be savarnas, and no featural definition of this term is given. It says that when a short vowel is mentioned, it stands for the short and long savarna sounds. 256 This seems to exclude consonants, extra-long vowels, diphthongs and / $1 /$ from the scope of the term savarna. 257 Though this conception does not seem to cover the groups of homogranic stops, the $\underline{\mathrm{RPr}}$ does have the notion of varga "group of five homorganic stops. "258

10.2.2. After this, the RPr uses the term savarna only once, and that also in the context of consonants. The term savarna-pūrva "preceded by a savarna" is used in the context of stops. 259 The example given by Uvata is yad devāh, where / $d$ / in devăh is preceded by /d/, which is a savarna "identical varna." If it were preceded even by $/ \mathrm{n} /$, still it would not fulfill the condition. This means that $/ d /$ is savarna only with $/ \mathrm{d} /$, and not with any other sound.

10.2.3. Thus, for the $\mathrm{RPr}, / \mathrm{a} / \mathrm{h} / \mathrm{i} / \mathrm{d} / \mathrm{u} /$ and $/ \mathrm{r} /$ are respectively savarna with $/ \overline{\mathrm{a}} /, / \overline{\mathrm{i}} /, / \overline{\mathrm{u}} /$ and $/ \overline{\mathbf{r}} /$, , and $/ \mathrm{d} /$ is savarna with $/ \mathrm{d} \%$. Looking at these examples, we might be able to dig out a general conception of savarna, which basically seems to mean "belonging to the same varna." The term varna functions on two levels. Its primary meaning is just a "sound." In its extended meaning, it stood for an abstraction, which may be characterized as "the real sound" or "class of sounds sharing some essential features." Thus, in the primary sense of the term, $/ \mathrm{a} /$ and $/ \bar{a} /$ are different varnas "sounds," but in the extended sense, they both belong to the same varna. The origin of this extended notion of varna can be traced in the idea that a long vowel is essentially the same as the short vowel, but which has been prolonged. Thus quantity, nasality and pitch were in some sense added features to a given common factor. It was this common factor which came to be designated by the term varna. Then the term savarna can be explained as directly based on this extended notion of varna. Thus, /a/ and /a/ are savarnas 
"belonging to the same varna." This extended notion of varna, however, did not change very much with consonants. Thus, the term savarna used with respect to consonants stood moreover for "identity of the sound." The sounds $/ \mathrm{k} /$ and $/ \mathrm{kh} /$ did not belong to the same varna, and hence could not be grouped under the conception of savarna. This was the reason for having the concept of varga "group of homorganic stops" side by side with the concept of savarna "belonging to the same varna."

Of course, the RPr adopted this background notion of savarna to its own needs, and restricted it to simple vowels. There also it excluded $/ 1 /$ and extra-long vowels. This is based on the praticular needs of this particular system. The RPr used the term in the context of consonants in the sense of "identity of varna." Thus, from this particularized conception of savarna, we have to infer the background conception.

10.2. 4. Though there is no comprehensive rule of homogeneous-representation like P.1.1.69, still we find the following system of representation in the $\underline{\mathrm{RP}}$ :

[1] A short simple vowel also stands for its long varieties.

[2] No other vowel can stand for other varieties.

[3] The terms $/ \mathrm{ka} /$-varga etc. stand for the respective groups of homorganic stops.

[4] Otherwise, a consonant stands for itself.

The RPr seems to be in a more primitive stage compared to other Prätisankhyas, where these things are stated in the form of explicit rules.

10.2.5. The concept of savarna is not used very frequently by the RPr, and many rules are formulated with terms like sasthāna "having the same point of articulation," where other Prātiśākhyas use the term savarna. For instance, the rule of the substitution of a long vowe $i$ for two consecutive simple homogeneous vowels is formulated with the term sasthāna "homorganic." 260 
Since the term savarna is used in a very limited sense, and is not defined in featural terms, there are no problems such as P.1.1.10. There is no concept of mutual homogeneity of $/ \mathrm{r} /$ and $/ 1 /$. There seems to be no problem of how to make $/ \bar{a} /$ and $/ \bar{a} /$ savarnas of one another. There are two reasons for this. The first reason is that savarna is not featurally defined, but depends on the impressionistic and conventional notion of varna. The other reason is that the $\mathrm{RPr}$ considers all vowels including /a/ to be asprsțta "without contact." 261

\subsection{THE TAITTIRĪYA-PRĀTIŚĀKHYA}

10.3.1. The TPr contains more points of interest than the RPr. The rule TPr (1.3) says: "The corresponding two sounds, short and long, are homogeneous (savarna)."262 As the commentary Tribhāsya-ratna explains, the sequences such as $/ a /-/ a /, / a /-/ \bar{a} /, \cdot \frac{\bar{a}}{-\bar{a} /}$, and $/ \bar{a} /-/ a /$ are sequences of homogeneous vowels. 263 This definition applies only to the simple vowels (samāna), and there are nine of these according to the TPr, i.e. $/ \mathrm{a} /, / \overline{\mathrm{a}} /, / \overline{\mathrm{a}} 3 / ; / \mathrm{i} /, / \overline{\mathrm{i}} /, / \overline{\mathrm{i}} 3 /$; $/ \mathrm{u} /, / \overline{\mathrm{u}} /$ and $/ \overline{\mathrm{u}} 3 / .264$ Thus, this conception of savarna is restricted to short and long $/ \mathrm{a} /, \mathrm{i} /$ and $/ \mathrm{u} /$. The $\operatorname{TP} r-1.4)$ says that a simple vowel preceding an extra-long vowel is not savarna with the latter. 265 This prevents the undesired lengthening.

The commentary points out that the only purpose of the term savarna is to formulate a rule for savarna-dirgha "homogeneous lengthening." This is the rule TPr $(x .2)$ (dīrgham samānākșare savarna-pare) "If a simple vowel is followed by a homogeneous sound, then both are replaced by the corresponding long vowel. "266 The exclusion of $/ \mathbf{r} /$ from the scope of the term savarna is quite understandable, because "in fact, no case occurs in the Vedic text in. which two of them are fused into one." 267

10.3.2. The commentator says that "the term (savarna) is self-explanatory. Homogeneity means similarity. Thus there should be no suspicion of /a/ being regarded homogeneous with $/ \mathrm{i} / \mathrm{etc}$, since they have different points of 
articulation and internal effort. "268 The description of savarna sounds here seems to be quite influenced by the notions in the Päninian system (P.1.1.9). However, such a general conception is not intended by the $\mathrm{TPr}$.

10.3.3. Though there is no rule in the TPr based on homogeneity like P.1.1.69, still the TPr has its own devices:

Rule (i.16): A sound followed by the affix -kāra is the name of that sound.

Rule (i.20): A short vowel, with the word -varna after it, is the name of the three vowels [ short, long and extra-long] .

Rule (i.27): The first mute, followed by the word -varga is the name of the series. 269

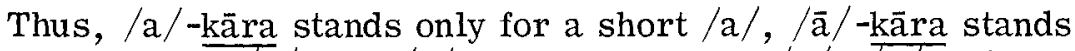
for only long $/ \bar{a} /$, but $/ a /$ varna stands for $/ a /$, $\overline{\bar{a}} /$ and $/ \bar{a} 3 /$. But there is no such a thing as $/ \bar{a} /$-varna. This corresponds to the non $-/ \mathrm{a}-\mathrm{N} /$ vowels in Panini, in some respects. Similarly, only /ka/-varga can stand for the whole series, but $/ \mathrm{k} /$ by itself cannot. This is also similar to Pănini's treatment of the sounds marked with $/ \mathrm{U} /$. While the TPr keeps the notions of savarna and grahana quite apart, Pānini builds an inter-dependent procedure of savarnagrahana.

In the $\mathrm{TPr}$, there is neither $/ \mathrm{r} /$-varna, nor $/ 1 /$-varna. Whitney rightly says:

As our treatise acknowledges no protracted $/ \mathrm{r} /$, and neither a long nor a protracted $/ 1 /$, it does not admit the compounds / $\mathrm{r} /$-varna and $/ 1 /$-varna: of the other three it frequently avails itself. $270^{-}$

In this respect, the procedure of the TPr differs from Pannini's, as the latter does bestow the capacity to stand for their savarnas on $/ \mathrm{r} /$ and $/ 1 /$, by P.1.1.69.

10.3.4. The problem of homogeneity in the TPr is made complex by the fact that it keeps on using the term savarna, 
even in the context of consonants. In the context of syllabification, the TPr (xxi.7) (nāntahsthā-param asavarnam) says: "If a consonant is followed by a semi-vowel and is asvarna 'non-identical' with that semi-vowel, then it does not belong to the preceding vowel, [but belongs to the following vowel]."272 On this rule, the commentary Tribhäsya-ratna explains the word asavarna with vilaksana "different." 272 Whitney explains this usage as follows:

'Dissimilar' is simply explained by vilakșana, 'of diverse characteristics, different, 'it excludes from the operation of the rule doubled semi-vowel itself, and would also exclude the nasal semi-vowel into which $/ \mathrm{n} /$ and $/ \mathrm{m} /$ are converted before $/ 1 /$, and $/ \mathrm{m} /$ before $/ \mathrm{y} /$ and $/ \mathrm{v} /(\mathrm{v} .26,28)$, if these occurred where the rule could apply, which is not the case. 272

If asavarna can thus mean "different," savarna should then mean "non-different, the same." The TPr does use the term savarna in this sense. For instance, the TPr (xiv. 23) (savarna-savargiya-parah) says: "A sound followed by the same sound (savarna), or by a sound of the same series of stops (savargiya) is not duplicated."274 Here the term savarna stands for identity of form, and not just identity of the point of articulation and internal effort. This rule draws for us the important distinction between savarna "identity of a sound" and savargiya "belonging to the same series of homorganic stops." Thus, $/ \mathrm{p} /$ and $/ \mathrm{p} /$ or $/ \mathrm{y} /$ and $/ \tilde{y} /$ are savarnas, but $/ \mathrm{k} /$ and $/ \mathrm{kh} /$ are only savargiyas "belonging to the same series. "275 In the Panninian conception of savarna, which is far more expanded, this distinction is dissolved. There, the savargiyas are also savarnas.

10.3.5. The distinction between savarna and savargiya affects the rule-formation of the $\overline{\mathrm{TPr}}$. W Where $\overline{\text { Pannini can }}$ have just one rule, the TPr needs two rules:

[1] TPr (v.27) (makārah sparśa -paras tasya sasthānam anunāsikam): "The sound $/ \mathrm{m} /$, when followed by a stop, becomes a nasal of the same point of articulation with it." 
[2] $\underline{\operatorname{TPr}}$ (v. 28) (antahsthā -paraś ca savarnam anunāsikam):

"Followed by a semi-vowel, $7 \mathrm{~m} /$ becomes an identical nasal [ semi-vowel] ."276

The reason why the TPr needs these two rules is quite clear. According to its conception, /y/ and / $\tilde{y} /$ are savarnas "the same sound," but $/ \mathrm{t} /$ and $/ \mathrm{n} /$ are not. They are only sasthānas "sharing the same point of articulation." With his expanded notion of savarna, Pānini needs only one rule, i.e. 8.4.58 (anusvärasya yayi para -savarnah).

10.3.6. An overview of the $\underline{T P r}$ shows that its conception of savarna is basically the same as that of the $\mathrm{RPr}$, discussed in Sec. 10.2.3. It is based on the expanded notion of varna, which can be clearly seen in the convention of affixing -varna to short vowels to stand for long and extra-long varieties. In this extended notion of varna, the features of quantity, nasality and pitch seem to become non-distinctive for inclusion in a varna. Such a background conception of varna is used in the notion of savarna "identity of a varna." Such a general notion of savarna is then restricted to particular needs of our treatise. As far as vowels are concerned, the TPr restricts the notion of savarna only to short and long/a/, $/ \mathrm{i} /$, and $/ \mathrm{u} /$, while the RPr, as already shown, included long and short $/ \mathrm{r} /$ also. This would indicate that the same background conception of savarna was adopted for their particular needs by different works. 277

\subsection{THE ATHARVAVEDA-PRĀTIŚĀKHYA}

10.4.1. The text which we shall consider under the name APr is the Śaunakiyā Caturādhyāyikā edited by Whitney, which is the same as the Kautsa-Vyākarana [ [see: Sec. 4.8] . In this text, the term savarna occurs only once. The APr (iii.42) (samānākșarasya savarne dīrghaḥ) says: "A simple vowel followed by a savarna vowel becomes long [along with the following]. "278 This rule is not too different from the TPr (x.2) (dīrgham samānākșare savarna -pare), except in the conventions of rule-formation. The TPr expresses the substitute in accusative case, while the substituenda are expressed in the nominative case. This is the convention 
of the older tradition, which is later continued by the Kātantra grammar. This is quite different from Pānini's grammar, where the substitute is expressed in the nominative and the substituenda are expressed in the genitive case. [P.1.1.49 (șașțī sthāne-yogā).] The APr has followed the same convention. But this single rule by itself would not help us understand the general notion of savarna in the APr.

10.4.2. On the APr (i.27), the unnamed commentary supplied by Whitney quotes a verse from some ancient Śikșā: samānāsya -prayatnā ye te savarnā iti smrtāh ${ }^{2} 279$ This line means to say that those sounds which are produced with a like effort [at a point in] the mouth are styled homogeneous. The expression of this definition is notably identical with P.1.1.9 (tylyāsya-prayatnam savarnam). The definition of this Siksā could not really be interpreted by taking the term a a sya-prayatna to stand just for internal effort, and hence, this definition becomes quite identical with Pannini's rule, and probably belongs to a very ancient date. At the same time, it must be pointed out that this is not the notion of savarna in the APr. Whitney comments:

The term savarna 'similar,' applied to sounds differing in quantity only, and not in quality, is used but once in our treatise (iii. 42), and is not defined by it: The cited definition is almost the same with that of Pānini (i.1.9): that of the Vāj Pr. (i.43) is more explicit: the other treatises, like our own, employ the word without taking the trouble to explain. 280

10.4.3. We are left to ourselves to figure out the conception of savarna in the APr. Could it be more like the RPr and TPr, or more like P.1.1.9? A close study of the $\overline{\mathrm{APr}}$ shows that the former is the case. Though the APr, unlike TPr, does not define the conventions of the usage of -kāra, -varna and -varga, behaviorally we can see that the same distinctions hold true in the APr. The affix -kāra appended to a vowel makes it stand for itself. For instance, /a/-kära in the APr (ii.92) excludes $/ \bar{a} / .281$ The affixation of 
-varna helps short simple vowels to stand for their varieties differing in quantity. Thus, we have /a/-varna, / $/$-varna, $/ \mathrm{u} /$-varna, /r/-varna etc. 282 But the long simple vowels and diphthongs always go with -kāra, e.g. /āa/-kāra (iii.38), /î/-kāra (i. 74), /ū/-kāra (i. 74), /e/-kāra (i. 34), /o/-kāra (i. 3), /ai/-kāra (i. 41) and /au/-kāra (i.41). With consonants, if there is affixation of -akāra, they stand for themselves; but the sound $/ \mathrm{k}(\mathrm{a}) /, / \mathrm{c}(\mathrm{a}) / \mathrm{etc}$. affixed with -varga stand for the respective series of homorganic stops. We also see that, unlike Pannini, but like the RPr and the TPr, the APr widely uses the concept of sasthāna "having the same point of articulation," where Pānini uses savarna. 283 This would show that the notion of savarna in the APr must be similar to that in the RPr and TPr. For other reasons, we may agree with Thieme and Liebich that "the author of the AVPr. did draw upon Pāninin's grammar, "284 but we do not have to identify the two conceptions of savarna.

10.4.4. Since the notion of savarna in the APr is more like the two other Prātisāankyas, based on identity of varna, conventional and impressionistic, it is not faced with many problems, which Pānini was faced with. Thus, there is no problem similar to P.1.1.10.285 The APr considers the short /a/ to be closed (samvrta), and other vowels to be open (vivrta) 286 Still it does not create problems similar to P. 8.4. $\overline{68}$ (a a). 287 If the notion of the APr were like P.1.1.9, there would have been all these problems. The very fact that there are no problems like this in the APr is a negative proof that its notion of savarna is different from Pānini's. The VPr, which defined savarña like P.1.1.9, is faced with all these problems, and had to make specific efforts to get out of them.

\subsection{THE VĀJASANEYI-PRĀTIŚĀKHYA}

10.5.1. The VPr goes under two other names, i.e. Suklayajuh -prātis̄ākhya and Kātyāyana -prātiśākhya. There is a pointed controversy whether the same Kātyāyana wrote vārttikas on Pānini and this Prātišākhya. 288 We shall not deal with this vexed question here, but will limit our inquiry to comparing and contrasting various definitions of savarna. 
10.5.2. The VPr (i.43) defines savarna as follows: samãnasthãna -karānāsya-prayatnah savarnaḥ: "A sound which has the same point of articulation, articulator and the internal effort [with another sound] is termed savarna 'homogeneous' [with respect to that other sound] ."289 This is clearly a featural definition. Of the three conditions, the first two, i. e. the points of articulation and articulators, are discussed in detail in the VPr. 290 However, the ãsya-prayatnas or internal efforts are not discussed by the VPr. If we follow Uvata's commentary, there are six âsya-prayatnas: samvrta "closed" for /a/, vivrta "open" for other vowels, asprstata "lack of contact" for vowels, sprstată "contact" for stops, ișat-sprștată "slight contact" for semi -vowels and ardhasprsțtata "half-way contact" for spirants and anusvâra. 291

Since vowels and spirants have different internal efforts, they are not savarnas of each other, and thus there is no need for any rule like $\bar{P} \cdot 1.1 .10$. However, $/ \mathrm{a} /$ is closed, while other vowels are open, and hence /a/ would not be homogeneous with $/ \bar{a} /$. The $\operatorname{VPr}$ is aware of this problem and explicitly says (i. 72) that they should be treated as if they are homogeneous (savarna -vat). 292 "It contains in words what is implied in the procedure of Panini; who has used the ingeneous device of pronouncing in his grammar a sound different from what it is like in the actual language. "293 Pānini pronounces /a/as an open sound in his grammar, so that it should be homogeneous with the open $/ \bar{a} /$ and $/ \bar{a} 3 /$. In the final rule of his grammar, P.8.4.68 (a a), he reinstates the closed $/ a /$. This is the final operation in any derivation, and hence we never get open $/ a /$ in the object language.

10.5.3. There is apparently a problem still left in. The sounds $/ i /$ and $/ e /$ are produced in the same point of articulation (tãlavya "palatal") 294 and their articulator is the middle of the tongue, 295 and both are open sounds. Similarly, $\mathrm{h} / \mathrm{and} / \mathrm{o} /$ are both labial (osthya), 296 and their articulator is also the lips. 297 These two are also open sounds. Thus, /i / would be homogeneous with /e/, and /u/ would be homogeneous with $/ 0 /$. However, this does not seem to be intended by the VPr. This could be avoided, perhaps, by considering $/ \mathrm{i} /$ and $/ \mathrm{u} / \mathrm{as}$ vivrta "open" and $/ \mathrm{e} / \mathrm{and} / \mathrm{o} /$ 
as vivrta-tara "more open," as has been done by many Śikșās and Prātisāākhyas. 298

10.5.4. The definition of the VPr needs to be compared with P.1.1.9 and Kātyāyana's vārttika on it. P.1.1.9 conditions homogeneity by àsya-prayatna, which in Kātyāyana's days came to stand only for internal effort. However, if homogeneity is conditioned by internal effort alone, then the sounds $/ \mathrm{j} /, / \mathrm{b} /, / \mathrm{g} /, / \mathrm{d} /$ and $/ \mathrm{d} /$ could also be homogeneous. With such an objection, the Vārttikakāra Kātyāyana rephrases P.1.1.9 as follows: siddham tv āsye tulya-desa-prayatnam savarnam "The correct result is established by stating that a sound is homogeneous [with another sound, if they share] the same point of articulation and internal effort in the mouth." [For details: Sec. 2.4.] This reformulation speaks of two conditions, while the definition of the VPr has added identity of the articulator as the third condition. Thieme considers P.1.1.9 to be "concise, but not precise, "the VPr definition to be "not concise, but precise" and the vārttika reformulation to be "both precise and concise." 299

10.5.5. In his "Pānini and the Veda," Thieme says that according to Patañali "the place of articulation (desa) is formed by the passive (sthāna) and active organ (karana). "300 If this is the meaning of the word desta in the varrttika, then both the vārttika and the VPr (i. 4) would be quite synonymous with each other.

This is doubtful. In fact, Patanjali does not explain the word desa with any other word. Instead of accepting Kätyäyana's reformulation, which leads to breaking up Pāninin's rule, Patañjali proposes to reinterpret Pānini's words as they stand. Thus, he interprets the word ãsya as meaning not just mouth, but as something that lies in the mouth [ãsye bhavam]. Then he asks the question: "What is it that lies in the mouth?" The reply is: sthānam karanam ca "The point of articulation and karana. "301 This passage was taken by Thieme as an interpretation of the word desa. The term karana here is explained by Kaiyata as standing either for internal effort or for the active organ. 302 It can be conclusively proved that here Patanjali only intends 
internal effort. This is what Patañjali says:

If the designation savarna were simply based on some similarity with some difference, then such a designation would be obtained for $/ \mathrm{s} /$ and $/ \mathrm{ch} /$, /s/ and /th/, and /s/ and /th/. These [ sounds in each pair] have identity in all other respects, except karana. 303

The sounds / $\mathrm{s} /$ and $/ \mathrm{ch} /$ have the same articulator, but they differ only in their internal effort. The same is true of the other pairs. Thus, the term karana in this context can only stand for internal effort. Thus, Thieme's explanations need to be revised.

10.5.6. Thus the term deśa in Kātyāyana's vārttika stands only for sthāna "point of articulation." Thieme himself, from quite different considerations, comes to accept this view in his later writings:

Formerly ["Panini and the Veda," p. 92, n. 3], I suggested that Kätyāyana's de'śa was meant as a comprehensive term for sthāna and karana. I do not uphold this conjecture: it is hard to believe that Kātyāyana could have expected to be understood when introducing such usage without further explanation. It is more probable that (in contradistinction to the view taken in the Vāj. Prat.) he thought of the mentioning of karana in the definition to be dispensable, since the definition is, indeed, unambiguous without it. In fact, the definition of the vārttika conforms to the pattern of a true laksana, which is not a characterizing description, but a restrictive characterization, as was lucidly set forth by A. Foucher, "Compendium des Topiques": (Paris 1949) pp. 8 ff. 304

Whether we agree with Thieme's views on the relationship of the two texts, i.e. the vārttikas and the VPr, or we disagree with him, his characterization of the vārttika definition is quite significant. 
10.5.7. Now, we enter into a problem which needs to be critically analysed. Thieme says: "A full and complete analysis of what Pānini obviously meant by the expression. ãsya -prayatna is given in Vãj. Pr. I. 43."305 He also thinks that the term karana "articulator" in the VPr definition is not essential, and therefore, Kătyāyana took it out in the vārttika on P.1.1.9.

Whether karana "articulator" as the third condition is non-essential needs to be tested by referring to the usage of the VPr. According to the VPr, nāsika "nose" is an articulator of the nasal sounds. 306 If the difference of articulator is to cause non-homogeneity, then $/ a /$ and $/ \tilde{a} /$, $/ \mathrm{y} /$ and $\tilde{y} /, / \mathrm{k} /$ and $/ \dot{\mathrm{n}} /$ would be non-homogeneous. For Pānini, these sounds are obviously homogeneous, and he uses the term savarna in the context of these sounds. Thus, in the sequences $/ \dot{\mathrm{m}} /-/ \mathrm{y} /$, and $/ \dot{\mathrm{m}} /-/ \mathrm{k} /, / \dot{\mathrm{m}} /$ changes into $/ \tilde{y} /$ and $/ \dot{\mathrm{n}} /$ respectively, such that $/ \tilde{\mathrm{y}} /$ and $/ \dot{\mathrm{n}} /$ are parasavarnas "homogeneous with the following sounds." 307 But the VPr uses the term para-sasthana "having the same point of articulation with the following sound, "in this very context. 308 It also says that $/ \mathrm{m} /$, followed by a stop, changes into the fifth of the series of the following. 309 Even here, the term savarna is not used. Is it, then, possible, that for the $\mathrm{V} \overline{\mathrm{Pr}}, 7 \mathrm{y} /$ and $/ \tilde{\mathrm{y}} /$ are only sasthāna, but not savarna? Similarly, is it possible that $/ \mathrm{k} /$ and $/ \dot{\mathrm{n}} /$ belong to the same series, but are not savarna?

10.5.8. Despite the arguments in the previous section, it is hard to believe that nasality causes hon-homogeneity in the $\mathrm{VPr}$. If $/ \mathrm{a} /$ is not homogeneous with $/ \tilde{\mathrm{a}} /$, then we may not be able to apply the VPr (iv. 50) (sim savarne dirghah) 310 to a sequence like /a/ $/$ a / to derive $/ \bar{a} /$. We cannot say that such a combination is not desired by the VPr, because the very next rule says: (VPr iv. 51) (anunāsikavaty anunāsikam) "In case the following vowel is a nasal, [the resulting vowel] is nasal. "311 This clearly allows that kind of combination. Similarly, we cannot say that $/ y /$ and $/ \tilde{y} /$ are not homogeneous. The rule VPr (iv.110) (savarne) says: "[Doubling does not take place] when a homogeneous consonant follows. "312 The example given by Uvata includes 
the sequences $/ \tilde{y} y /$ and $/ \tilde{\mathrm{v}} \mathrm{v} /$, where there is no duplication. 313

Thus, in summary, we must say that inclusion of karana in the definition is not carried to its logical conclusions, and hence, in view of the requirements, it is unnecessary. Thieme is certainly right in regarding it to be dispensable. That karana "articulator" is dispensable is clearly stated, later, by Hemacandra [ref: Sec. 12.7.2] .

10.5.9. Uvata, on the $\operatorname{VPr}$ (i. 43), says that even the sounds $/ \mathbf{r} /$ and $/ 1 /$ can be combined in a savarna-dirgha, if an example is found in the Vedic usage. 314 This, actually, seems to be an extension of Kātyāyana's vārttikas into the $\underline{V P r}$, but has no basis. The sounds $/ \mathrm{r} /$ and $/ 1 /$ have different points of articulation, and articulator, and hence they cannot be homogeneous. ${ }^{315}$ Nor is their homogeneity imposed by the VPr. In fact, Uvata himself indicates that /1/ never figures initially or finally in the object language. 316 Thus, there is no possibility of such savarna-dirgha.

10.5.10. Though the conception of savarna in the VPr seems to be identical in scope with $\overline{\mathrm{P} .1 .1 .9}$, the $\overline{\mathrm{VPr}}$ does not utilize this conception as extensively as it is used by Pānini. The VPr still follows the tradition of the Prātisankhyas in formulating its rules. Thus, there is no rule of savarnagrahana like P.1.1.69, and the VPr follows other Prātiśākhyas in their conventions of -kāra, -varna and -varga. The usage of -kāra, in the expressions like /a T-kāra, /ka/-kāra etc. is clearly defined. 317 The VPr defines that a short vowel stands for long and extra-long vowels, and a first consonant of a series stands for the series in the section where points of articulation are explained. 318 This is somewhat similar to P.1.1.69, but this is restricted to a very small number of rules. The VPr continues to utilize affixation of -varna and -varga. It still uses terms like sasthäna, where its own conception of savarna could have been used. Thus, the VPr resembles Pânini's grammar only in its definition of savarna, but not in its implementation.

10.5.11. Finally the question that we ought to ask is whether the VPr needs the kind of definition of savarna it has given 
to account for its own usage of this term. The rule VPr (iv. 110) (savarne) requires $/ y /, / v /$ and $/ 1 /$ to be homogeneous with their nasal counter-parts. The third and last rule using the term savarna is the VPr (iii. 8) (pratyayasavarnam mudi sākatāyanah). This rule says that $/ \mathrm{h} /$ followed by $/ \mathrm{s} /, \frac{\mathrm{s} /}{\text { or } / \mathrm{s}} /$ changes to a sound homogeneous with the following. Here $/ \mathrm{s} /, / \hat{\mathrm{s}} /$ and $/ \mathrm{s} /$ are required to be homogeneous with themselves. These are the only three rules in the VPr which use the notion of savarna.

If we look at the examples closely, it will be instantly clear that they can be savarnas simply because they show identity of the varna, and fit well in the notion of savarna of the other Prãtisākhyas. Thus, the definition of savarna in the VPr is unnecessarily over-extensive, and compared to its own requirements, it is quite superfluous. It may be the case, that the author of this Prātis̄ākhya came under a heavy influence of Pānini's grammar, and hence gave the expanded definition of savarna. However, while writing his rules, he faithfully followed the tradition of the other Prātišākhyas.

\subsection{THE SĀMAVEDA-PRĀTIŚĀKHYAS}

10.6.1. There are four texts which go under the general category of the Sāmaveda -prātišākhyas, i.e. the Rk-tantra attributed to the pre-Pãninian Sākațāyana, the Sāma-tantra ascribed to Audavraji, the Puspasutitra ascribed to Pusparși, and the Akșaratantra. Of these four texts, only the Rktantra has general discussion of phonetics, while the other texts are concerned more with the particular problems of Säman-recitation. The Rk-tantra shows the tendency of shortening the grammatical terms, e.g. mãsa for samāsa, rga for varga, gha for dirgha etc. The term savarna is never used in any of these texts. The term sva is used in the Rk-tantra occasionally for identity of an element [e.g. kānt sve, Rk -tantra 155, kān-śabdah sve pratyaye sakāram āpadyate/ kāms kān ha jayati , comm. p. 34]. The Rk-tantra [25, sparsah sve] says that a stop followed by a sva belongs to the preceding vowel. Here sva seems to cover sounds of the same varga [ see: Notes to R. $\underline{\text { k-tantra, }}$, by Surya Kanta, 
p. 14, n. 25]. Within a particular section of the Rk-tantra, a stop stands for its varga [ sparśe rgasya, Rk-tantra 13, sparśa-grahane vargasya grahanam vijñeyam, comm. p. 7] . Thus, $/ \mathrm{k} /, / \mathrm{c} /, \mathrm{t} /, / \mathrm{t} /$ and $/ \mathrm{p} / \mathrm{stand}$ for the respective vargas in the rules [4] jihvā -mūle hkrr, [5] tăluni ścye, [6] mürdhani satau, [ 7$]$ dante tslāh and [9] osthe vohpu [ see: Rk-tantra, $\overrightarrow{p p} .5-6]$. In one case, $/ \mathrm{r} /$ seems to stand

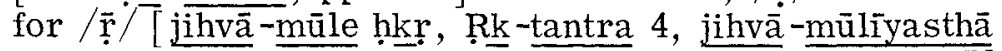
jihvā -mūla-sthānāḥ kakāra-rkāra -ṛ̂kārāh, comm. p. 5] . In some rules, $/ \mathrm{e} /$ and $/ \mathrm{o} /$ seem to stand also for $/ \mathrm{ai} /$ and /au/ [ tāluni ścye, Ṛk-tantra 5, tālu-sthānāḥ śakāra-cakārayakāra-ikāra-ikāra-ekārāh, comm; and oșthe vohpū, Rktantra 9 , oșthya -sthānā vakāra -okāra -aukāra upadhmānīyapakāra -ukāra -ūkārāh, comm, p. 6]. The commentary seems to be somewhat inconsistent in including /au/ in rule 9, but in not including /ai/ in rule 5 . It is important to note that Śākatâyana, who is supposedly pre-Pāninian, accepts vowels and spirants to be both open [vivrtaim svarosmanām, 1.3, p. 3]. The same tradition might have continued up to Pānini forcing him to construct P.1.1.10 (nājjhalau). But in contrast to Pānini, Sākatāyana accepts $/ a \sqrt{\text { and } / \bar{a} /}$ to be both open, or rather more open [vivrtataram akāraikāraukārānām, 1.3, p. 3] . [Note: In this statement, akāāra seems to cover ākāra also.]

10.6.2. The Puspa-sūtra has nothing parallel to savarna. It uses the term sva [ = svakiya] in connection with sāmans belonging to a group [see: Puspa-sūtra, Einleitung, p. 507]. Expressions with -kāra and -varna are quite frequent, and the notion of savargiya "belonging to the same varga" is occasionally used [Puspa-sütra, pp. 636, 639, 667]. The Sāma -tantra ascribed to Audavraji is very important from the point of view of ancient grammatical terminology, but it has no notion of savarna. It uses the term ga for varga [see: na ga-prathama-cu, 3.5.6., na varga-prathamādir mandram āpadyate, comm., Sämatantra, $\mathrm{p}$. 89]. In one place, $/ \mathrm{t} /$ seems to stand for tavarga [see: au ti, 5.5.9., p. 156]. Unfortunately I have not been able to obtain the Aksara-tantra, but from its description, it seems to be very much similar to the Sãmatantra. Thus, as far as the notion of savarna is concerned, 
the Prātisāakhyas of the Sāmaveda have many unfinished ideas, but no conclusive development. In some ways, they may reflect a more ancient state of grammatical development, compared to the Prätisankhyas belonging to the other Vedas. However, the exact dates of these texts are not as yet definitely known. The Mātrālakșana, an ancillary text of the Sāmaveda, uses the term savarna once (1.9) in the context of homorganic varieties of $/ \mathrm{a} /, \mathrm{Ti} /, / \mathrm{u} /$ and $/ \mathrm{r} /$. [Mātrālakșana, ed. B. R. Sharma, Kendriya Sanskrit Vidyapeetha, Tirupate, 1970.] However, nothing is known about the author or the date of this text. 



\section{CHAPTER XI}

\section{ŚIKSTĀS ON SAVARNA}

11.1. As it has been already discussed in Sec. 10.1., the class of the Sikșā-texts is extremely old to have been mentioned in the Upanisads, and it is older than the Prātisāakhyas and Pānini. However, it must be remembered that the Siksa texts which are available to us today are certainly not these old Śikșās, but are all younger than the Prātisâakhyas and Pānini [sèe: Sec. 10.1] .

11.2. The main purpose of the Sikșās is phonetics, pure and applied, and not grammar. Thus, the Śiksās extensively deal with the articulatory process in all its aspects and classify sounds accordingly. These phonetic considerations have been utilized by the grammarians to define certain grammatical categories. The notion of savarna is based on these phonetic considerations, but serves a purpose which is more grammatical. The difference in phonetic considerations can lead to problems in the definition and implementation of savarna. When one reads through the available Siksā texts, one comes across different notions of savarna, which may be put together and studied carefully. What follows is an attampt in this direction. At this stage, we shall not see how phonetics here affects the notion of savarna elsewhere, but rather what the Sikșās themselves have to say on this notion.

11.3. The metrical version of the Păniniya -śiksā does not use the term savarna, but the Panniniya-siksā-sütras contain two statements involving this term. They are as follows: [1] "The spirants and / $r$ / have no savarnas," and [2] "A member of a varga (group of homorganic stops) is savarna with other members of the same varga. "319 The first statement is identical with a statement found in the Mahābhäsya, and its significance has been discussed in 
Sec. 7.1.9. The Pāniniya-śiksā-sūtras seem to have taken this statement from Patañjali. 320 They appear to be postPatañjali, because we find that the rule (3.6) says: "the spirants have their articulator with a slight gap," while the rule (3.7) says: "or they might be regarded open. "321 This seems to be an attempt to accomodate views of both Pānini and Patañjali. Similar rules are also to be found in the Śiksāa-sūtras ascribed to Âpisali. 322 [For a different view, see n. 124.]

11.4. The Varna -ratna -pradipikā-śikșa of Amareśa apparently presents quite a strange notion of savarna. It says:

Whatever is the point of articulation (sthāna) and articulator (karana) of a sound, [if it is the same with another sound, then] it should be accepted as savarna [ with respect to the other sound] . [Their] internal effort (āsya-prayatna) may, however, be different. 323

Thus, identity of the point of articulation and the articulator defines homogeneity, and the internal effort is not to be taken into account. This Sikșâ clarifies the reason for adopting such a view:

Let there be homogeneity of long / $/ \bar{a} /$ and short $/ a /$, despite the difference of internal effort. Therefore, [homogeneity] is thus defined. 324

The short /a/ sound is closed, while the long / $/ \bar{a} /$ is open, and hence there might not be homogeneity of these two sounds, if internal effort is one of the conditions.

For this very problem, Pānini pronounces open /a/ in his grammar, and reinstates the closed sound /a/ at the end of his grammar (P. 8.4.68). The VPr makes a special rule to consider $/ \mathrm{a} /$ and $/ \bar{a} /$ as if they are homogeneous. [Sec. 10.5.2.] These measures seem to be very careful, but modifying the general definition as is done by the Varna -ratna-pradīpikä-sikșā creates a lot of problems. For instance, this conception could make /i/, /c/-series, 
$/ \mathrm{y} /$ and $/ \dot{s} /$ homogeneous with each other. However, it is not clear how this conception was meant to be utilized, because the term is used only once again, where $/ \mathbf{s} /, / \mathrm{s} /$ and $/ \mathrm{s} /$ are required to be homogeneous with themselves. 325 This Siksā also defines a convention that a sound affixed with -varna stands for its homogeneous sounds. 326

11.5. The Prātisākhya-pradīpa-śikșā comments on the rules of the VPr containing the term savarna, without really explaining the term. 327 On one occasion, the term savarna is rendered by sadrsa "similar." 328 This Sikșä advocates homogeneity of $7 \mathbf{r} /$ and $/ 1 /$, quoting the vārttika of Kătyāyana (r-l-kārayoh savarna-vidhih) (on P.1.1.9). This homogeneity is used to interpret a rule from the Pratijna-suitra. The Pratijña-suttra prescribes that $/ \mathrm{r} /$ should be pronounced as /re/. Thus, krsna and rtviya are to be pronounced as kresna and retviya. The Sikșā extends this rule to $/ 1 /$ and says that klpta should be pronounced as klepta. 329

The Keśavi-śiksā of Keśava Daivajña says that a rule that applies to $\overline{T r} /$ also applies to $/ 1 /$, because they are savarna "homogeneous." 330 This is a somewhat different context. This rule requires that the svara-bhakti of $/ r /$ in some places is pronounced as $/ \mathrm{re} /$. Thus the word barhise is pronounced as barehise. The Keśavi-śikșā extends this to $/ 1$, and says that valhāmasi should be pronounced as valehāmasi.

11.6. F. Kielhorn quotes the definition of savarna given by the Vyāsa-śikșā: tulya -rūpam savarnam syāt "Sounds with identical form are savarnas. "331 Unfortunately, I have not been able to reach the original text of this Siksā, which has been published in the Journal of the University of Madras (1929). 332 Heinrich Lüders" study "Die Vyāsa -śikșā, besonders in Ihrem Verhaltnis zum Taittiriya-Prātis̄ākhya," [Göttingen, 1894] is very detailed, and provides some help on the conception of savarna in the Vyãsa-sikșā. In his "Inhaltsübersicht der Sikșä," Lüders provides the following description:

Verse (5): "Definition von varga," and "Bildung des 


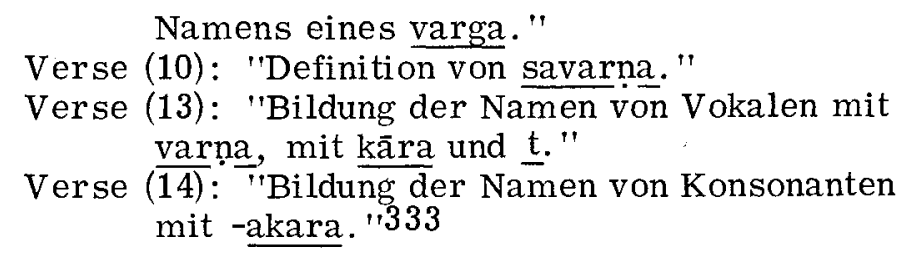

This system looks very much like the Prātiśākhyas, and hence the definition of savarna (tulya -rūpam savarnam) seems to stand basically for identity of a varna.

That the Vyāsa-sikșa is very much in the tradition of the Prātiśākhyas can be determined by studying several of its rules which involve the notion of savarna. The verse (166) is described as: "Behandlung des $/ \mathrm{i} /$-Vokals und des $/ \mathrm{u} /$-Vokals vor nicht homogenen (asavarna) Vokalen."334 This seems to be the change of $/ \mathrm{i} /$ to $/ \mathrm{y} /$ and $/ \mathrm{u} /$ to $/ \mathrm{v} /$ before a -savarna "non-homogeneous" vowels. The verse (172) is described as: "Verschmelzung der ersten acht Vokale mit einem folgenden gleich-artigen. "335 This is parallel to VPr (iv. 50, sim savarne dírghah), APr. (iii.42, samänākșarasya savarne dīrghah) and TPr (x.2, dīrgham Samãnaksare savarna-pare); and it is different from P.6.1.101 (akah savarne dirghah) in its structure. The verse (269) is described as: "Zugehörigkeit des Konsonanten vor ungleichartigem Halb-volkal." 336 This rule discusses the syllabic relationship of a consonant with the following a savarna semi-vowel, and it is comparable to the TPr (xxi.7, nāntahsthā -param asavarnam) [Sec. 10.3.4] . Liuders has systematically brought home the point that this Siksã is almost a versified version of the TPr. Thus, the notion of savarna in the Vyāsa-śiksā is generally not different from the Prātisāakya-type of definition. 337

11.7. An unnamed commentary on the APr quoted by Whitney cites a verse from a Śikșā text: samānāsya -prayatnā ye te savarnā iti smrtāh, and comments "the cited definition is almost the same as that of Pānini" [ ref: Sec. 10.4.2] . Literally this line says that two sounds having the same àsya -prayatna are savarnas. The use of the term a a syaprayatna, in this verse, is of historical significance. 
No text, other than P.1.1.9, uses the term āsya-prayatna to stand for both the points of articulation and internal effort. But this Siksā uses the term to stand for both of these conditions, like Pānini. If it were to stand only for the internal effort, that would be quite a novel conception of homogeneity. Thus, this Sikșā seems to be very ancient and perhaps older than all those texts which use the term àsya -prayatna to stand just for internal effort. It may even be pre-Pāninian. Thus, Pānini was not alone in his usage of the term āsya-prayatna to stand for both the point of articulation and internal effort.

The Nāradiya -śikșā belonging to the Sāma-veda uses the term savarna twice. It says that $/ \mathrm{m} /$ followed by $/ \mathrm{y} /$, $/ \mathrm{v} /$ or $/ 1$ changes to a para-savarna "sound homogeneous with the following. "338 This does not help us get a clear notion of savarna, since this rule could be formulated in the Pāninian conception of savarna as well as in the Prātiśākhya conception. The term savarna is also used with respect to yama (e.g. nasal $/ \overline{\mathrm{k}} /, / \widetilde{\mathrm{g}} / \overline{\mathrm{etc}}$. found in Vedic). This yama is said to be savarna "homogeneous" with the preceding sound. 339 The commentary of Bhatta Śbhākara on this verse explains savarna by sadrs sa "similar."340 In the Pāninian grammar, yamas do not play any important role. They are not listed in the Sivasütras, nor are they considered to be homogeneous with any consonants. Bhartrinari says that the yamas are neither represented through homogeneous representation, nor through universal-mention. 341 The Nāradiya-Sikșā seems to use the term in a very general sense of identity of the varna and similarity.

11.8. The concept of savarna in some of the Sikșās seems to come very close to the Păninian conception. The Śaisiriyasikșā says that a word-final $/ \mathrm{m} /$, followed by a stop, changes into a nasal sound homogeneous (savarna) with the following stop [ antya -sthāne makāro'yam pūrvah sparśe padāntagah.] udaye tat-savarnaḥ syāt sarvasminn anunāsikah $/ /$, verse 281, Journal of Vedic Studies, Vol. II., No. 2., 1935, p. 15] . This verse makes $/ \mathrm{n} /$ and $/ \mathrm{t} /$ homogeneous with each other, which is very similar with Pānini's procedure. A similar 
usage of the term savarna is seen in the Vyāsa -śikșā [ see: n. 337] and Sarva - Sammata -śikṣā [ see: sparśānām yavalānām ca makārah pūrva -sthitah teșām avāpnuyāt ślișțe savarnam anunāsikam /7, verse 16; the commentary of Alamücu Mañcibhațta on this verse says: samāno varnah savarnah, tulya -sthäna -karanah; Bhandarkar Oriental Research institute, Poona, MS. No. 383 of $1883-84$, folio 7] . The Kaundinyaśikșa uses a triple distinction of terms: savarna in the context of savarna-dirgha, sarüpa "with identical form" for "identity of sound" and savargiya "belonging to the same stop-series." [See: na sarüpa-savargiya-paro varno dvir ucyate, verse 68; savarña-dírgha in verses 87 and 89 . Prof. $\overline{\mathrm{K}}$. V. Abhyankar, Poona, has a copy of this Sikșa made from the single MS which exists in a private collection in Hyderabad. This is planned to be published in the Annals of the Bhandarkar Oriental Research Institute.] The Siks ādhyāya of the Bharatabhāsyam by Nānyabhūpāla says that some scholars considered $/ 1 /, / h /$ and $/ \mathrm{r} /$ to be savarnas of each other because they have the same point of articulation and internal effort. It also refers to Nārada's opinion that $/ u /$ is savarna with $/ \mathrm{v} /$ and $/ \hat{\mathrm{s}} /$ is savarna with / $/$ / Bharatabhäsya, Sikșãdhyāya, verses $48-9$, p. 21]. The context indicates that the term has been used for nothing more than "similar sounds." 


\section{CHAPTER XII}

\section{NON-PANNINIAN GRAMMARS \\ ON SAVARNA}

12.1. A comprehensive study of the conception of savarna cannot be complete without considering its definitions and implementation in the non-Pāninian systems of Sanskrit grammar. There is an extensive published literature of these systems, and they have drawn some attention of scholars. Among the studies on these systems, noteworthy are Liebich's translation of the Kātantra ["Das Kātantra," Zur Einführung in die indische einheimische Sprachwissenschaft I, Heidelberg, 1919] and his Konkordanz PāniniCandra [Breslau, 1928]. Also noteworthy is A. C. Burnell's Essay on the Aindra School of Sanskrit Grammarians [Mangalore, 1875].

Many scholars have devoted articles to non-Pāninian systems of Sanskrit grammar, but Franz Kielhorn is perhaps unique in this field in having worked with so many different systems, even before they were published. His articles include: 1) "Tndragomin and other Grammarians" Indian Antiquary, vol. 15, 1886, pp. 181-3] ; 2) "On the JainendraVyākaraña" [Indian Antiquary, vol. 10, 1881, pp. 75-9]; 3) "The Chāndra-Vyākarana and the Kāsikā-Vritti" [ Indian Antiquary, vol. 15, 1886, pp. 183-5];4) "On the Grammar of Săkațāyana" [Indian Antiquary, vol. 16, 1887, pp. 24-8] ; 5) "Scheinbare Citate von Autoritäten in grammatischen Werken" [ Festgruss Böhtlingk, 1888, pp. 52-3] ; 6) "A Brief Account of Hemachandra's Sanskrit Grammar" [Wiener Zeitschrift, vol. 2, 1888, pp. 18-24] ; 7) "Malayagiri's Samskrit Grammatik" [Göttinger Nachr., 1892, pp. 318-327] ; and 8) "Die Sākatāyana -Grammatik" [ Göttinger Nachr. , 1894, pp. 1-14] . 
Also noteworthy are the following articles: 1) "Das Cāndra-Vyākarana, " Bruno Liebich [Nachrichten von der Königl. Gesellschaft der Wissenschaften zu Göttingen, Phil. Hist. Klasse, 1895]; 2) "The Text of the Jainendra-Vyākarana and the Priority of Candra to Pūjyapäda, "K. B. Pathak [Annals of the Bhandarkar Oriental Research Institute, vol. 13, 1931-2] ; 3) "Ist Candragomin der Verfasser der Cāndra-vṛtti?" R. Birwé [Mélanges d'Indianisme à la mémoir de Louis Renou, Paris, 1968] ;4) "Über die Grammatik Kātantra," Otto Böhtlingk [ ZDMG, Vol. 41, 1887] ; 5) "Kātantra und Kumāralāta," Heinrich Lüders [BSB, Phil. Hist. Kl., 1930, also included in Philologica Indica, Göttingen, 1940] ; 6) "Moggallānas Saddalakkhana und das Cāndra -Vyākarana, " Otto Franke [Journal of the Pali Text Society, Vol. 53, 1903] ; 7) "Das Verhältnis von Candra's Dhātupātha zu den Pāli Dhātupāthas, Otto Franke, [Ibid.] ; 8) "A Glimpse into the Käśakrtsna School of Sanskrit Grammar," G. B. Palsule [Proceedings and Transactions of the All India Oriental Conference, 17th Session, 1953]; 9) "The Technical Terms of the Harināmāmrta -Vyākarana of Jiva Gosvāmin," G. B. Palsule [CASS Studies, No. 2., University of Poona, Poona, 1974] ; 10) "Kāśakṛtsna," K. C. Chatterjee [Indian Historical Quarterly, Vol. VIII, 1932] ; 11) "A Note on Apiśali," V. Pisani [Journal of the Oriental Institute, Baroda, Vol. 5, 1956]; 12) "Aspects of pre-Pāṇinian Sanskrit Grammar, "Batakrishna Ghosh [‥ ‥ Law Comm. Volume] ; 13) "The Relation of Pānini's Technical Devices to his Predecessors, "Mangala Deva Shastri [ Proceedings of the 4th All India Oriental Conference, 1926] ; 14) "Les 'innovations' de la grammaire de Candragomin," Louis Renou [Etudes de Grammaire Sanskrite, Paris, 1936] ; 15) The Sanskrit Dhätupāthas, a Critical Study, G. B. Palsule [ Poona, 1961], (a comparative study of the Dhātupa thas of the various systems of Sanskrit Grammar); 16) Geschichte und Kritik der einheimischen Pāli -Grammatik und -Lexicographie, Otto Franke [Strassburg, 1902 ], (contains material on various systems of Sanskrit Grammar in comparison with Pāli grammatical systems); 17) Robert Birwé's extensive introduction to the edition of the Śākațāyana-vyākarana [ Bhāratĩya Jñānapițha Prakāshan, Banaras, 1971], (which discusses a great many historical 
problems); and 18) Ācārya Hemacandra aur unakā Sabdānuśāsana: Eka Adhyayana, Nemichandra Shastri [Banaras, 1963].

Apart from such specialized studies, general accounts of these systems are found in Colebrooke's "On the Sanskrit and Prakrit Languages" [ A siatic Researches, Vol. VII, 1803, pp. 199-231]; Belvalkar's Systems of Sanskrit Grammar [Poona, 1915]; K. V. Abhyankar's Introductory Volume [Vol. VII] (Prastāvanā-Khanda) to his father's complete Marāthī translation of the Mahābhāsya [Poona, 1954]; Yudhisthir Mimamsaka's Vyākarana [Ajmer, 1961-2] in three volumes; and Gurupada Haldar's Vyākaraṇa Darśanera Itihāsa [Calcutta, 1350 Bengali Era, 1943 A.D.] . Several texts in several editions on these nonPāninian systems have been published in India and abroad, and there is enough material available for a comparative study. In our study of the conception of savarna in these systems, we shall follow approximately the order of systems given in the "Chronological Conspectus of the Different Schools" in S. K. Belvalkar's Systems of Sanskrit Grammar. Though this "Conspectus" could certainly be improved, we shall not deal here with matters of pure chronology.

12.2. ĀPIŚALI ON SAVARNA Pānini refers to Āpiśali in P.6.1.94 (vā supy āpišleh). 'Though Āpiśali's grammar has not come down to us, there are Sikșā-sūtras ascribed to him. These do not provide a definition of savarna, but use the term twice. This Sikșā says that the spirants and $/ \mathrm{r} /$ have no homogeneous sounds, and that a member of a varga is homogeneous with other members of the same varga. 342 From these two statements we are left to infer Apis̉ali's conception of savarna. Since $/ \mathrm{k} /, / \mathrm{kh} /, / \mathrm{g} /$, $/ \mathrm{gh} /$ and $/ \dot{\mathrm{n}} /$ are considered to be savarnas, the point of articulation must be one of the conditions. However, it could not be the only condition, because, in that case, $/ \mathrm{k} /$ would be homogeneous with $/ \mathrm{h} /$. This has been denied by this text. Thus, $/ \mathrm{k} /$ and $/ \mathrm{h} /$ are not savarnas. This might indicate that internal effort was also included in the definition of savarna. According to this Siksā, the spirants are ísadvivrta "slightly open," while stops are sprsțta "with contact." 343 
Since spirants are slightly open, and vowels are open, there is no need of any rule such as P.1.1.10 (nājjhalau). It also speaks of samvrta "closed" short /a/.344 This would create the problem of non-homogeneity of $/ \mathrm{a} /$ with $/ \overline{\mathbf{a}} /$, That would indicate that Apisali must have had some way to get around this difficulty. This close similarity with Pănini's grammar makes us wonder why Pānini did not follow Apisali in considering spirants to be slightly open? That would have spared him the trouble of formulating P.1.1.10. Most of the later grammars have accepted this subclassification. It is somehow hard to think that this subclassification existed before Pānini and yet Pānini took the trouble of formulating P.1.1.10. It may be that the Śiksāa ascribed to Apisali is actually a late work in that tradition, which accepted the classification made by Patañjali. [For a different view, see: n. 124.] There is yet no decisive evidence to prove that this text is older than Pạnini.

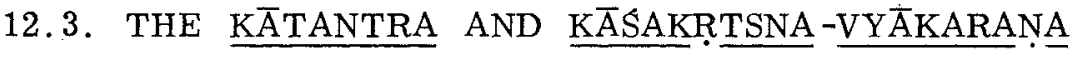

12.3.1. Burnell believed that terms like savarna were taken by Pạnini from the Aindra School of grammar. 345 Burnell also believed that the Kătantra system reflects this ancient school. 346 The Kātantra takes for granted its list of sounds (varna-samāmnāya), where the first fourteen

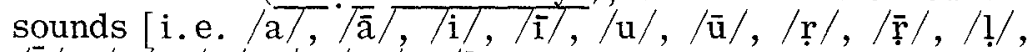
$/ \overline{1} /, / \mathrm{e} /, / \mathrm{o} /, / \mathrm{ai} /, / \mathrm{au} /]$ are vowels; and of these the first ten are termed samāna "simple vowels." 347 Then the term savarna is introduced: Kăt (1.1.4) "Of these [ simple vowel $]$, two by two are savarna with each other. "348 Liebich explains this term as "von gleicher Kaste." 349 In fact, more than "Kaste," the term savarna is related to the linguistic meaning of varna. Then the term is used in the following rules. Kătantra (1.2.1) says: "A simple. vowel followed by a homogeneous vowel is lengthened and the following vowel is deleted." 350 Though the procedure here is different from the single-substitute (ekādeśa) procedure followed by the Prâtisâakhyas, still it is terminologically closer to them than to Pâninini. The rules $(1.2 .8-11)$ say that before an asavarna vowel, the $/ \mathrm{i} /$-vowels, /u/-vowels,

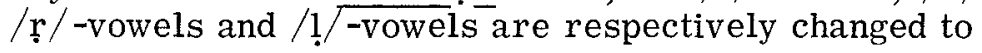


$/ \mathrm{y} /, / \mathrm{v} /, / \mathrm{r} /$ and $/ 1 /$, and the following sound is not deleted. 351 The rule $(3.4 .56)$ says that $/ \mathrm{i} /$-vowels and $/ \mathrm{u} /$-vowels of the first element of the root-reduplication are replaced by $/ \mathrm{iy} /$ and $/ \mathrm{uv} /$, before an asavarna vowel. 352 These are the only occurrences of the term savarna in the Kātantra-vyākarana. Thus, we might say that the notion of savarna here is quite in the tradition of the Prätisankhyas, except that it is extended here to $/ 1 /$ and $/ \overline{1} / 353$ But the Prātisākhyas use this concept of savarna also with consonants, in the sense of "identity of varna." The Kätantra does not use this term with respect to consonants. The conventions of using the affixation of -kāra, -varna and -varga are the same as in the Prātis̄ākhyas.

12.3.2. The original Kătantra system makes independent rules for $/ \mathrm{r} /$ and $/ 1 /$ and thus there seems to be no notion of their homogeneity. 354 However, as Eggeling points out: "Between 4 and 5, the Laghuvrtti adds two sütras, or rather vārttikas (a) rkāra-lkārau ca and (b) vargyah svavargyena. "355 This seems to be a later introduction in the Kātantra under influence of Kātyāyana's vārttikas. These two statements mean that $/ \mathrm{r} /$ and $/ \mathrm{l} /$ are homogeneous with each other, and that members of a varga are homogeneous with each other. The second statement seems to bring the Kātantra notion of savarna closer to Pânini's notion. This is also a late attempt. The commentary of Trilocanadāsa on this system points out that homogeneity of $/ \mathrm{r} /$ and $/ \mathrm{l} /$ is established on the basis of worldly usage of these sounds. 356 This conception of Trilocanadāsa is refuted by the Laghubhãsya by saying that people do not identify $/ \mathbf{r} /$ and $/ 1.357$

12.3.3. The Kātantra-paribhāsā -sūtra-vrtti of Bhāvamiśra contains the following maxim: varna-grahane savarnasyāpi grahanam. 358 This is an explanation of the affixation of -varna to short simple vowels, so that they also stand for the long varieties. This is the principle of grahana "representation" followed by the Kātantra system.

12.3.4. We may here refer briefly to the grammar of Käsakrtsna. In 1952, A. N. Narasimhia published the 
Käśakrtsna -Śabdakalāpa -Dhātupātha of Cannavĩrakavi [Sources of Indo-Aryan Lexicography: 5, Deccan College, Poona, 1952]. It contains a Dhātupātha ascribed to Kăsakṛtsna, with a brief Sanskrit and Kannada commentary. This commentary quotes a few rules of Kāsakrtsna's grammar. [For a survey of views on Kãsakrtsna's date, see my review of S. D. Joshi and J. A. F. Roodbergen, VyākaranaMahābhāṣya, Karmadhārayāhnika, Publications of the Centre of Advanced Study in Sanskrit, University of Poona, Class C, No. 6, 1971 (review forthcoming in Orientalistische Literaturzeitung, Leipzig).] G. B. Palsule (1953) has presented an interesting study of Kāsakṛtsna's gàrammar based on the above mentioned Dhātupātha and the rules found in the commentary thereon. Kāsakrttsna is most probably post-Pãninian and pre-Kătyãyana [Palsule (1953), p. 350] . We have to mention Kāsakrrtsna in the context of the Kätantra system, because "excepting one or two solitary cases Kāśakrtsna agrees entirely with the Kătantra in the matter of the technical terms" [Ibid., p. 352] . Kā Sakrtsna uses the terms like samāna, nāmin, varga, sandhyakșara, -kāra, which show that he belongs to the general class of the Aindra type, which is seen in the Prātiśakkhyas and the Kātantra. Yudhisthir Mimamsaka (1961-2, Vol. I, p. 113) claims that the Kātantra is in fact a summary of Kāsakrtsna's grammar. This question still needs to be investigated further.

\subsection{THE JAINENDRA-VYĀKARANA}

12.4.1. The Jainendra -vyākaraña of Devanandin defines the term sva [ savarna] as: (1.1.2) "[A sound is termed] sva 'homogeneous' [with respect to another sound, if they share] the same point of articulation and internal effort. "359 This is quite parallel to P.1.1.9. The Mahāvrtti of Abhayanandin on this rule gives extensive details of phonetics and also of the scope of the term sva. According to the Mahãvrtti, spirants are slightly open, and vowels are open. 360 This follows Patañjali's subclassification. Thus there is no need of a rule like P.1.1.10. Similarly, there is no question of how $/ \mathrm{a} /$ and $/ \overline{\mathrm{a}} / \mathrm{can}$ become homogeneous. Abhayanandin says that the view [ of the Pāninians] that $/ a /$ is closed in 
the object language, but is open in grammar is false. There should be no difference of pronounciation in the object language and grammar. $361 \mathrm{He}$ explains that $/ \mathrm{r} /$ and spirants have no homogeneous sounds, but members of a varga are homogeneous among themselves. 362 All this is quite parallel to the Päninian conception.

12. 4.2. This system has a procedure which is identical with Pānini's savarna -grahana (P.1.1.69). The rule (Jain. 1.1. 72) says: " $\overline{\mathrm{An} / \mathrm{a}}-\overline{\mathrm{N}} /$ sound and a sound marked with $\overline{\mathrm{U} / \mathrm{s} / \mathrm{s} d \mathrm{~s}}$ for itself and for its homogeneous sounds, except if it is an introduced sound (bhāvya) or is marked with $/ \mathrm{T} / . " 363$ This rule combines several things in the Panninian system. It combines P.1.1.69 with P.1.1.70 and the maxim: bhävyamānena savarnānām grahanamim na [Sec. 8.2]. This shows that while constructing his grammar, Devanandin attempted to follow the late phase of Pāninian interpretation. Patañjali's suggestions are followed verbatum. The correspondence of this system with Pānini is so strong, that for almost every Pāninian rule with savarṇa, we find a rule with sva. 364 Due to the acceptance of Pānini's Siva-sutras with some minor modifications, with almost the same system of markers and metatheoretic conventions, rules of the Jainendra grammar look like a revised edition of Pānini's system. 365 To add to this, this system accepts homogeneity of $/ \mathbf{r} /$ and $/ 1 /$, following Kātyāyana. 366

\subsection{THE CĀNDRA-VYĀKARANA}

12.5.1. The system of Cāndra -vyākaraña of Candragomin follows Kātyāyana's suggestion of univer sal-mention, instead of following Pānini's homogeneous-representation. While commenting on his modified version of the Siva-sutras, Candragomin says that these sounds are intended to stand for their universals. 367 Thus, there is no definition of savarna nor is there any procedure like P.1.1.69.

12.5.2. Kātyāyana himself thought that even in universalmention, a rule of representation would have to be retained for the classes of stops. Thus, he suggested that only /a-N/ sounds should be omitted from P.1.1.69, retaining the rule 
udit savarnasya. [Sec. 3.16.] But this would make it necessary to have a definition of homogeneity like P.1.1.9. Candragomin found a better way out. He ruled that the initial sound of a varga, marked with $/ \mathrm{U} /$, stands for the respective varga (1.1.2).368 Thus he resorted to the older notion of varga, which Pānini had replaced with his expanded definition of savarna. He reformulated Pānini's rules in such a way that he could avoid using the term savarna. 369 Instead, he made use of the older terms like sasthanna, which are selfexpressive (anvartha) and do not need any definition. 370 Candragomin has shown independence in not following Patañjali, but in following Kātyāyana's suggestions. As we shall see later, there were other systems which followed Kātyāyana's suggestions, but Candragomin was the pioneer in this direction.

One thing, however, is not very clear. Why did Candragomin accept the theory of universals, which is not accepted by any Buddhist school of philosophy? The Jain grammarians, right at the outset, say that their grammars are based on the Jain doctrine of anekānta "many-faced nature of reality." Thus, they accept individualism (vyaktiväda) and universalism (âkrtrti-vāda) as the need be. But Candragomin apparently has accepted a non-Buddhist philosophical theory. It is possible that he accepted only the conceptual-reality of these universals.

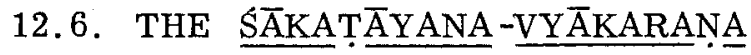

12.6.1. Under this name, we shall consider the work of the Jain Saakațāyana, who is clearly post-Pāninian. The grammar of the pre-Pāninian Sãkațāyana is now lost to us, unless he is the author of the Rk -tantra. The system of Sākațāyana also tries to fuse together the Päninian notion of homogeneity with Kātyāyana's notion of universal-mention.

On his modified version of the Pāninian Siva-sūtras, Sākatāyana says in his Amoghavrtti that the vowels listed here also stand for long, extra-long and nasal varieties, since they share the same universal (sāmānya = ākrtî). 371 This is quite parallel to Kātyāyana's proposal of universal- 
mention. A short vowel stands for long and extra-long varieties sharing the same universal, unless it is either an introduced sound (bhāvya) 372 or marked with $/ \mathrm{T} / .373$ This rule is somewhat similar to Jainendra (1.1.72), in accepting the maxim of introduced sounds, and incorporating it into the rules of grammar. But the Jainendra does not accept universal-mention.

12.6.2. At the same time, Sākatāyana gives a comprehensive definition of sva (= savarna), which is quite parallel to P.1.1.9. Homogeneity is conditioned by identity of the point of articulation and internal effort. 374 The discussion of this definition in the Amoghavrtti involves certain problems. It considers $/ \mathrm{a} /$ to be closed and $/ \bar{a} /$ and $/ \bar{a} 3 /$ to be open. 375 It is clear as to how Sākațāyana tried to get around this problem.

Since there is universal-mention, he does not need them to be homogeneous. The Amoghavrtti says that the sound /i/ etc. have eighteen varieties, while about the /a/-vowels, it says that /a/-kāra is six-fold, while the long and extra-long varieties are twelve in all. 376 The reason behind this separation is not clearly stated. The only conceivable way seems to be that even if $/ a /$ and $/ \vec{a} /$ are not homogeneous, still they share the same universal. This would overcome many problems. The spirants are classified as slightly open, and vowels are classified as open, and hence there is no need of a rule like P.1.1.10.377 This system follows Patañjali in his subclassification, and the conclusion is also stated that $/ \mathrm{r} /$ and spirants have no homogeneous sounds. 378

12.6.3. Though Sākatāyana accepts universal-mention for vowels, he does not accept it for stops. The universal of $/ \mathrm{k} /$ does not cover $/ \mathrm{kh} /, / \mathrm{g} /, / \mathrm{gh} /$ and $/ \mathrm{n} /$. This is quite parallel to Kātyāyana's understanding [Sec. 3.16]. Thus, he makes the rule (1.1.2) that a sound marked with $/ \mathrm{U} /$ stands for its svas "homogeneous sounds."379 While Candragomin's rule (Cāndra. 1.1.2, utā sva-vargasya) is based on the notion of varga, Sākațãyana's rule, like P.1.1.69, is based on the notion of homogeneity. However, the Amoghavrtti seems to redefine the rule in terms of the notion of varga. 380 
Śākațāyana consistently carried out Kātyāyana's suggestion for homogeneity of $/ \mathrm{r} /$ and $/ 1 /$. He accepts their homogeneity repeatedly in his grammar, and reformulates the Siva-sutra $r-1-K$ by $r-K$. 381 He clearly says that the rules which apply to $7 \mathrm{r} /$ aiso apply to $/ 1 /$, and offers the fictional examples of $/ 1 /$, which are so commonplace in the later Pāninian tradition. 382

12.6.4. Though Candragomin and Sākațãyana both tried out Kātyãyana's suggestion for universal-mention, in a way, Śăkatāyana is closer to the spirit of Kätyāyana. Candragomin made a vigorous effort to get rid of the notion of savarna, but Sākatâyana replaces only certain parts of savarna-grahana. This is very similar to Kätyāyana, who suggests removal of only /a $-\mathrm{N} /$ sounds from P.1.1.69, and retaining udit savarnasya. Thus, Śākatāyana retained the term sva in many rules, while Candragomin tried to get rid of it. 383 The commentary Cintāmani of Yakșavarman and the Prakriyāsamgraha of Abhayacandrasūri follow the interpretations given by the Amoghavrtti and have very little new to add.

\section{7. THE HEMACANDRA-ŚABDĀNUSASANA}

12. 7.1. Hemacandra's Sabdānuśāsana with his autocommentary Brhad-vrtti represent a peculiar fusion of the Panninian notion of homogeneity and the rest of the technical terminology which mostly comes from the Kätantra system. Nemichandra Shastri has pointed out this mixed nature of Hemacandra's technical terminology, 384 though his extensive comparisons have not touched the details of Hemacandra's conception of sva and its application in his system.

12.7.2. Hemacandra defines sva "homogeneous" as: (1.1.17) "[A sound is termed] sva [with reference to another sound, if it has the same point of articulation and internal effort."385 This definition is clearly identical with P.1.1.9. Hemacandra's Brhad-vrtti presents a very extensive and systematic account of phonetics. Hidden in the comments of the Brhad-vrtti, there lies, perhaps, a historical suggestion that Hemacandra based his definition not on P.1.1.9, but rather on the VPr (i. 43, samāna-sthāna -karanāsya-prayatnah 
savarnah). Hemacandra uses the term sthāna for the points of articulation, and āsya-prayatna for internal effort. Of the three conditions of the VPr, Hemacandra omitted the second condition, i.e. karana "articulator." The Brhadvrtti says: "Karana 'articulator' which is the root, middle, forward and the tip of the tongue does not differ when the point of articulation and internal effort are identical." 386 This comment of Hemacandra actually supports Thieme's conclusion that karana in the definition of the VPr is logically superfluous [Sec. 10.5.6].

12.7.3. Hemacandra quotes extensively from the Apisaliśiksā-sütras. He accepts Patañjali's subclassification of "open."387 Thus there is no need of a rule like P.1.1.10. Similarly, Hemacandra subscribes to the view that short $\mathrm{a} /$ is open, and says that according to others, short $/ \mathrm{a} /$ is closed. 388 Thus, for him there is no problem of $/ a /$ being non-homogeneous with $/ \bar{a} /$.

12. 7. 4. However, there is no rule exactly parallel to Pănini's homogeneous-representation (P.1.1.69) in Hemacandra. On the contrary, he follows the Prātisaäkhyas and the Kātantra in their conventions of affixing -kāra, -varna and -varga. He has defined the usage of -kāra and -varga, 389 and the affixation of -varna, though undefined, is quite uniform. Thus, the rules in this system look more like rules in the Kătantra, than like Pānini's rules. 390

12.7.5. Hemacandra's grammar must be clearly distinguished from the VPr. The VPr defines savarna with scope equal to P.1.1.9, but the rules where the term savarna is used do not need such a broad conception. Such is not the case with Hemacandra. Hemacandra needs this broader conception of savarna for some of his rules. Hemacandra's rule (1.2.21) says that $/ i /$-vowels etc. are respectively replaced by $/ y /$, $/ \mathrm{v} /, / \mathrm{r} /$ and $/ 1 /$, if followed by a non-homogeneous vowel. 391 This rule does not need the broader conception. But the rules given below require this conception.

Hem. (1.3.14) says that an augment $/ \mathrm{m} /$ and a wordfinal $/ \mathrm{m} /$, if followed by a consonant, are replaced by a sound 
homogeneous with the following (para-sva). 392 By this rule $/ \mathrm{m} /-/ \mathrm{y} /$ is changed to $/ \tilde{\mathrm{y}} /-/ \mathrm{y} /$, and $/ \mathrm{m} /-\mathrm{k} /$ is changed to $/ \dot{\mathrm{n}} /-/ \mathrm{k} /$. The second case requires the broader notion of homogeneity. This is quite similar to Pānini's procedure. 393 The other rule which needs the broader conception is Hem. (1.3.48): "If a non-nasal stop, $/ \hat{\mathrm{s}} / \mathrm{,} / \mathrm{s} /$ or $/ \mathrm{s} /$ is preceded by a consonant and followed by a homogeneous sound from this very group, it may be optionally deleted."394 Thus, in the sequence $-/ \mathrm{n} /-/ \mathrm{d} /-/ \mathrm{dh} /-, / \mathrm{d} /$ might be optionally deleted. This requires homogeneity of $/ d /$ and $/ \mathrm{dh} /$, which can only be obtained by the broader conception. This is also parallel to Pānini. 395

12.7.6. The notion of $/ \mathrm{r} /$ and $/ 1 /$ being homogeneous does not seem to have been accepted by Hemacandra. He always treats them separately and sometimes even writes separate rules. 396 However, this notion seems to have entered his system through later commentators. Hemahamsagani, in his Nyãya-samgraha, mentions the following maxim: "An operation prescribed with reference to $/ \mathrm{r} /$ also applies to $/ 1 / . " 397$ This seems to be based on the supposed homogeneity of $/ \mathrm{r} /$ and $/ \mathrm{l} /$.

12.7.7. A comparison of Pānini's grammar with Hemacandra shows that though the broader conception adopted by Hemacandra is not unnecessary, still his terminological dependence on the Kātantra did not allow him to fully utilize the power of this conception. Thus, compared to Pānini, Hemacandra's utilization of sva is more restricted.

\subsection{THE ŚABDANUŚĀSANA OF MALAYAGIRI}

12.8.1. Malayagiri's Śabdānusāāsana is not available to us in its entirety, but a substantial portion of it has been recovered and published recently by Bechardas J. Doshi. Fortunately, this portion is sufficient to give us a complete idea of his conception of homogeneity. Following his Jain predecessors, Malayagiri prefers the term sva for savarna. Malayagiri (dvitiya-sandhi, 1) defines sva as based on identity of the points of articulation and internal effort. 398 $\mathrm{He}$ considers spirants to be slightly open and avoids any 
rule such as P.1.1.10.399 Similarly, he considers /a/ to be open, and hence there is no problem of non-homogeneity of $/ \mathrm{a} /$ and $/ \bar{a} / .400$

12.8.2. However, Malayagiri does not have a rule of savarnagrahana like P.1.1.69. Like Hemacandra, Malayagiri is also terminologically dependent on the Kātantra to a great extent. The conventions for the affixation of -kāra, -varna and -varga are similar to the Kătantra. He also rules that a consonant marked with /U/ stands for its varga. $401 \mathrm{He}$ does not use the notion of sva in this rule. Malayagiri is also dependent on the Siva-sūtras of Pannini and the modified version of Sāakatāyana. He defines short and long $/ \mathrm{a} /, / \mathrm{i} / \mathrm{and} / \mathrm{u} /$ to be $/ \mathrm{a}-\mathrm{N} /$; short and long $/ \mathrm{i} /, / \mathrm{u} /, / \mathrm{r} /$ and $/ \mathrm{l} /$ to be $/ \mathrm{i}-\mathrm{K} /$; /e/ and $/ \mathrm{o} /$ as $/ \mathrm{e}-\mathrm{N} /$; and $/ \mathrm{e} /, / \mathrm{o} / \mathrm{h} / \mathrm{ai} /$ and $/ \mathrm{au} / \mathrm{as}$

$/ \mathrm{e}-\mathrm{C} / .402$ This definition of $/ \mathrm{i}-\mathrm{K} /$ is based on Pānini's Siva-sūtras, and not on the modified version of Sàkațāyana, because he has only $/ \mathrm{r}-\mathrm{K} / .403$ It could have been based on Jainendra's version, but there is no certainty about that version. However, Malayagiri defines $/ y /, / v /, / r /$ and $/ 1 /$ by the term /ya- $\tilde{\mathrm{N}} / .404$ This is clearly based on Sākatāyana's version, where we have $/ \mathrm{ha} /-/ \mathrm{ya} /-\mathrm{va} /-/ \mathrm{ra} /-/ \mathrm{la} /-/ \tilde{\mathrm{N}} /$, which is different from Pānini. 405

12.8.3. With this mixed terminology, Malayagiri still needs the broader conception of sva. Though some of his rules could certainly use the restricted conception of the Kätantra, other rules require the broader notion. For instance, the rule (trtiya-sandhi, 2) says: $" / \mathrm{i}-\mathrm{K} / \mathrm{sounds}$ are replaced by [the corresponding] /ya $-\tilde{\mathrm{N}} / \mathrm{sound}$, if followed by a nonhomogeneous vowel." 406 This rule does not need the broader conception of savarna. Similarly, the rule (trtiya-sandhi, 5) says: "A simple vowel, if followed by a homogeneous vowel, is replaced by a long vowel, along with the following. "407 This also does not need the broader conception.

But there are other rules, which need the broader conception. These rules require homogeneity of $/ \mathrm{g} /$ and $/ \dot{\mathrm{n}} /, / \mathrm{d} /$ and $/ \mathrm{n} /, / \mathrm{t} /$ and $/ \mathrm{n} /$ etc., which can only be obtained in the broader conception of sva. 408 Malayagiri draws an important distinction. He uses the term sarüpa for total 
identity. 409 This is different from sva. In general, Malayagiri's treatment of sva is very similar to Hemacandra.

\subsection{THE MAGDHABODHA -VYAKARANA}

12.9.1. The Magdhabodha-vyākarana of Bopadeva shortens the term savarna by rna, by retaining the last syllable of the older term. This is similar to his usage of the terms sva, rgha etc. for hrasva and dirgha. The term pluta is reduced to plu. 410 Not only is this shortform different from other systems, this conception itself is quite different from other conceptions.

12.9.2. Bopadeva defines rna as: (Mugdh. 6): "Similar (sama) stops (napa) and simple vowels (/a $-\mathrm{K} /$ ) are rna with each other [within the groups]; and $/ \mathrm{r} /$ and $/ \mathrm{l} /[/ \overline{\mathrm{r}}-\overline{\mathrm{K}} /$, though dissimilar] are also [ rna with each other] " 411 Bopadeva explains similarity (sāmya) in terms of identity of the points of articulation. 412 This is quite a different conception, and reflects Bopadeva's independent thinking. The condition of identity of the points of articulation applies separately to stops and simple vowels, and hence there is no need of a rule like P.1.1.10. As an exception to this identity of points of articulation, homogeneity of $/ \mathrm{r} /$ and $/ 1 /$ is specifically given. The definition is very clear and does not leave any doubt about Bopadeva's intentions.

12.9.3. With this definition, Bopadeva gives us his rule of rna-grahana: (Mugdh). 7): "The sounds capa (i.e. $/ \mathrm{c} / \mathrm{,} / \mathrm{t} /$, $7 \dot{\mathrm{t}} /, \mathrm{k} / \mathrm{and} / \mathrm{p} / \mathrm{h}$, if marked with $/ \mathrm{U} /$, and the sound $/ \mathrm{a}-\mathrm{K} /$ (i.e. $/ \mathrm{a} /, / \mathrm{i} /, / \mathrm{u} /, / \mathrm{r} /$ and $/ \mathrm{l} /$ ), if without any marker, stand for their homogeneous sounds." 413 Thus, /cU/, $/ \mathrm{tU} /$, etc. stand for the respective vargas, and short simple vowels stand for the respective long and extra-long varieties, if they are not marked with $/ \mathrm{T} /$ etc. The sound $/ \mathrm{r} /$ also stands for $/ 1 /$. This is the total extent of rna-grahana, which is smaller compared to Pānini's homogeneousrepresentation, where diphthongs and semi-vowels also stand for their homogeneous sounds.

12.9.4. Bopadeva has extensively used the procedure of 
rna-grahana, but the term rna occurs only once more. The rule (Mugdh. 22) says: "When [a vowel] is followed by a rna 'homogeneous' sound, both are replaced by a long variety. "414 This is the only rule where the term rna is used.

The fact that the Kătantra uses the term savarna only with simple vowels, and that, on other occasions, it has successfully used the notion of sasthāna, 415 seems to have influenced Bopadeva's thinking. At the same time, he must have realized the benefits of the Pāninian procedure of homogeneous-representation over the Kātantra and others, in reducing the expression of the rules. Thus, Bopadeva adopted a reduced version of P.1.1.9 and P.1.1.69. In this conception of homogeneity, Bopadeva stands alone.

\subsection{THE SARASVATA-VYAKARANA}

12.10.1. The Sārasvata -vyāka raṇa of Anubhūti-svarūpācārya seems to have been constructed by combining features of Pānini and the Kātantra. It uses terms like samāna and nāmin, which come from the Kātantra, but it has its own modified version of the Siva-sūtras, which is used to formulate shortforms. There is no general featural definition of savarna, but short, long and extra-long varieties of simple vowels are considered to be savarna. 416 Except for the inclusion of extra-long vowels, this seems to be parallel to the Kätantra notion of savarna. The Vrtti explains conventions for affixation of -kära, -varna and $/ \bar{t} /$, which are similar to the Kätantra. 417 The Sārasvata defines the terms $/ \mathrm{kU} /$, $/ \mathrm{cU} /$ etc. for the respective vargas. 418 The notion of savarna is used mostly with vowels. 419

12.10.2. Though the term savarna is not defined with respect to consonants, one rule uses it in such a context. Särasvata (990) says: "If a jhas sound [i.e. non-nasal stops, $/ \hat{\mathrm{s}} /, / \mathrm{s} /$ and $/ \mathrm{s} / \mathrm{l}$ is followed by a savarna sound from the same group, and is preceded by a has sound [i.e. a consonant], then it is deleted." 420 This requires the expanded notion of savarna, which does not exist in the Käntantra. The Vr.tti quotes a statement: "The members of a varga are savarnas 
among themselves. "421 This brings in the Pāninian notion of savarna, by the back door. Looking at the total implementation of the term, we can say that the scope of the concept of savarna in the Sãrasvata is the same as in the Mugdhbodha. But the latter has given a definition of [sava] rna, and has the procedure of rna-grahana, which does not exist in the former.

12.10.3. The Sārasvata rules in homogeneity of $/ \mathrm{r} /$ and / $/$ vowels. 422 This system goes further and also speaks of homogeneity of $/ \mathrm{r} /$ and $/ 1 /$; and quotes the view of the Alamkārikas that $/ \mathrm{d} /$ and $/ 1 /, / \dot{\mathrm{s}} /$ and $/ \mathrm{s} /$, and $/ \mathrm{b} /$ and $/ \mathrm{v} /$ are also homogeneous. 423 This actually refers to dialectal variation in the Middle Indo-Aryan. This device has been frequently used in Sanskrit poetry.

\subsection{SOME MINOR SYSTEMS}

12.11.1. The Sarasvatī-kanthābharana of Bhojadeva closely follows Pānini, with certain minor differences. Bhoja's definition of savarna is identical with P.1.1.9, except that he uses clearer terminology. He uses sthāna for the point of articulation and āsya-prayatna for internal effort. 424 Bhoja also accepts P.1.1.10 (nājjhalau) as his rule 1.1.102. 425 This is the only non-Pāninian system that has accepted this rule. However, Bhoja splits Pānini's savarnagrahana. His rule 1.2.2 (utā savargah) says that a sound marked with $/ U /$ also stands for its varga. Then the rule 1.2.4 (avidhiyamāno'n sa savarnah) says that an $/ \mathrm{a}-\mathrm{N} /$ sound which is not being ruled in stands for itself and its homogeneous sounds. Both of these rules are covered by P.1.1.69. In making use of the notion of varga, Bhoja seems to be combining the Kātantra with Pānini.

12.11.2. We shall also briefly look at the Pāli grammars of Moggallāna and Kaccãyana, since Burnell thinks that they show influence from the lost school of the Aindra grammar. 426 The Moggallāna grammar starts with the list of 33 sounds, and says that the first ten of them are vowels (sara), i.e. $/ \mathrm{a} /, / \overline{\mathrm{a}} /, / \mathrm{i} /, / \overline{\mathrm{i}} /, / \mathrm{u} /, / \overline{\mathrm{u}} /, / \mathrm{e} /, / \mathrm{ai} /$, $/ \mathrm{o} /$ and $/ \mathrm{au} .427$ Then it says that among them two by two are termed savanna ( = savarna) with each other. 428 This 
only refers to the simple vowels. This fits well with the Kätantra type of system. The sounds $/ r /$ and $/ 1 /$ do not appear in Pāli. The sounds /ai/ and /au/also do not appear in Pāli, but are listed with other sounds.

12.11.3. The Kaccãyana grammar clearly declares that the technical terms of the Sanskrit grammatical systems have been adopted. 429 The Kaccãyana grammar uses the term savanna without defining it. It is used only once in the rule Kacc. (1.2.3). 430 This rule explains a usage like na upeti changing into nopeti. It says that when $/ a /$ of na is deleted before $/ u /$ of upeti,$/ u /$ changes to $/ 0 /$ which is asavanna with $/ \mathrm{u} /$. Here the term asavanna seems to have been used in the sense of "different." The commentary Kaccāyana -vannanā says that short vowels are mutually homogeneous with the respective long vowels, and explains the term savanna with sarūpa "having identical form." 431 Though this last explanation may not stand with the Sanskrit grammarians, the previous one is within the influence of the Kātantra. Thus, both the grammatical systems show influence of the Kätantra, which may ultimately be traced back to Burnell's Aindra school of grammar.

I shall briefly refer to some of the non-Pāninian systems where my information comes from secondary sources. G. B. Palsule (1974, p. 26) discusses technical terms from the Harināmāmrta -vyākarana of Jiva Gosvāmin. The term for simple vowels in this system is daśâvatāra "ten incarnations, ten simple vowels, "i.e. $/ \mathrm{a} /, / \overline{\mathbf{a}} /, / \mathrm{i} /, / \overline{\mathbf{i}} /$, $/ \mathrm{u} /, / \overline{\mathrm{u}} /, / \mathrm{r} /, / \overline{\mathbf{r}} /, / 1 /$ and $/ \overline{1} /[$ daśa daśāvatārāh., 3$]$. Of these ten simple vowels, the homorganic pairs are homogeneous ekātmaka "with the same self" [ teșām dvau dvau èătmakau, 4]. Palsule says (ibid.) that the term for asavarṇa in this system is anekātmaka. The Harināmāmrta uses the term vișnu-varga for varga [te māntāh pañca pañca visnu -vargāh, $19 j$, and uses affixation of -rāma for -kāra of other systems [ varna -svarūpe rāmah, 37]. The Supadma vyākaraña of Padmanābha defines savarna as: vargya -svarau sajātíyau savarnau (1.1.15) (K. C. Chatterji (1948), p. 285). This seems to make use of the concept of jāti "universal" to define homogeneity. This is rather unique, because we find 
that these two concepts are kept distinct in other systems. Similarly this system also seems to extend the concept of universal to members of a varga. This is also unique. The Prayoga -ratna -māla of Purușottama defines that two homorganic (sasthāna) simple vowels are homogeneous with each other, and $/ \mathbf{r} /$ and $/ 1 /$ are also homogeneous with each other [ sasthānākau savarnah (?) syāt sāvarnyam r -1-varnayoh, 1.1.9] (K. C. Chatterji (1948), p. 285). This is very similar to the Mugdhabodha conception of (sava-) rna. 
CHAPTER XIII

\section{A HISTORICAL OVERVIEW}

13.1. Having reached the other end of the line, we can have an overview of the development of the notion of savarna and its implementation. Several scholars have compared and contrasted simply the definitions of savarna in different systems, without going into the function and implementation of this concept in those respective systems. 432 Such comparisons, though indeed very useful, do not give us the real relationships between these systems. For instance, the VPr definition of savarna is identical with Pănini's definition in its scope, but it is absolutely unnecessary to justify the usage of that term in that text. The definitions of the Jainendra, Sākatāyana, Hema -śabdānuśāsana etc. are identical with Pănini's definition, but the Jainendra follows Pāṇini's implementation, Śākațāyana follows Kātyāyana's suggestion of universal-mention, while Hemacandra retains a strong influence of the Kătantra. Thus, the definitions alone are not quite sufficient to give us the real historical relationships.

13.2. The term savarna is a very old term. It appears in the Rgveda (10.17.2) and the Atharvaveda (18.2.33), where Sāyaña explains it by sadŕśa "similar" and samāna -rūpa "having similar appearance." The term sāvarnya also appears in the Rgveda (10.63.9), but here it stands for Manu, the son of Savarnā. The earlier usage is, however, noteworthy. Though it has nothing to do with varna "sound," and is rather connected with varna "color," its general meaning of similarity must have contributed to the later grammatical notion.

In the early Vedic, we have more mythological and philosophical speculation on the speech-phenomenon, but in the Brāhmana texts we start getting a glimpse of the ancient 
grammatical activity. The Aitareya-Brāhmana knows the distinction between -varna and -kāra, ghosa and ūsman. 433 The Gopatha-Brähmana mentions a whole range of grammatical terminology, which we later find utilized by the known grammatical texts. 434 The Taittiriya-Upanisad quotes subject headings of an ancient Sikșā. 435 Weber has collected a large number of grammatical terms from the Vedic Kalpasutras. 436 These were self-expressive terms and, according to Burnell, they formed the technical terminology of the Aindra School of Grammar, whose continued existence is seen in the Prātiśākhyas, Kătantra and some of the later systems. 437 Pānini brought in more mathematical expressions, which were meaningful only according to the technical conventions of the system, and were mainly aimed at brevity in the expression of rules. He redefined some of the older terms and gave them a more comprehensive meaning.

13.3. The word varna primarily means color, but was used to stand for sounds in later days. It is important to see how the word standing for color could have been transfered to stand for sounds. This has already created a long controversy. In Goldstïcker's Pānini, we find the first full scale discussion of this problem. $\bar{B}$ efore Goldstiicker, Weber argued that varna stands for "coloring," or specializing of the sound. [Compare: rakta "colored" = "nasalized," Indische Studien, Vol. IV, Berlin, 1858, p. 109] . Max Müller followed Weber. Then came Goldstuicker who argued that varna refers to written letters, "arising naturally from its primitive sense "colour" " [Goldstuicker (1860), pp. 38-9] . Goldstïcker used this argument to substantiate his view that Pannini knew the script. Batakrishna Ghosa gives an explanation which makes more sense:

This meaning of the word varna should have been developed first in the Brāhmaña sa of the Sāmaveda in which we constantly come across locutions like rathantara -varnā rk "verse which gets the colour of Rathantara Sāman in chant." In these passages the word varna is visibly changing its meaning from "colour" to "sound" of melody. Thus, gradually, 
the "sound of melody" became "sound in general." ["Aspects of Pre-Päninian Sanskrit Grammar,"

B. C. Law Comm. Volume, p. 338; quoted by Chatterji (1948), p. 279.]

K. C. Chatterji himself, however, seems to favor the view that written letters "were covered with a coating of paint" [(1948), p. 279], and hence the word for color came to be used for sounds or letters.

Batakrishna Ghosa's explanation paves the way for a rather more consistent development. However, from very early days we come across association of types of Vedic hymns with different colors in the primary sense of the word "color." In the seventeenth chapter of the RPr, we find a detailed discussion of color distinctions of different types of Vedic hymns. The RPr lists seven different colors [17.8, p. 77] . It says that the fourfold Vedic Chandas is of kapila "brown" color [17.10, p. 78] . How ever, the RPr does not seem to associate individual sounds with different colors. This is seen in the Yājñavalkya-śikșā. It says that vowels are white, stops are black, semi-vowels are brown, spirants are redish, yamas are blue, anusvāra is yellow, visarga is white, nāsikya is green, nasal sounds are dark blue, while ranga is of a mixed color [S Siksâ-samgraha, pp. 13-14] . The Yãjñavalkya -śikșâ goes further and says that nouns are white, verbs are red, upasargas are brown while the nipātas are black [ibid, p. 14]. Different systems of Yoga and Tantra had different color-classifications of sounds, which had meditational and mystical significance. [For a brief informative account and bibliographical references, see: Yoga, by Ernest Wood, a Pelican Original, first published in 1959, revised reprint of 1971, pp. 153-4.]

As far as the non-mystical aspects are concerned, it seems more probable that the word varna "color" came to be used for sounds, by the secondary meaning of "color" standing for musical quality, and later for vocalic quality. It stands not only for a sound, but also for a comprehensive sound quality, mostly the vowel quality. In this extended meaning, it stood for "real sound" which is not affected by quantity, 
nasality and accent. This notion of a common-substance or real sound is an impressionistic notion. Thus, $/ \mathrm{a} /, / \overline{\mathrm{a}} /$ and $/ \bar{a} 3 /$ have the same sound-substance, and hence they belong to the same varna, whose minimal expression is naturally found in the short, non-nasal variety. But $/ \mathrm{k} /$ and $/ \mathrm{kh} /$ were not thought to have the same real sound-substance, and hence they belonged to different varnas, and thus the notion of varga "class of homorganic stops" came up. Thus, the notions of varna and varga were the earlier notions. Affixation of -varna to short vowels to stand for their long and extralong varieties is a later development based on this ancient notion of varna. It goes back to the days of the Brāhmana texts. This stage is perhaps reflected in the Sāmavedaprātiśākhyas of ancient Śākatāyana and Audavraji. However, the notion of savarna has not yet emerged.

13.4. The early conception of savarna is clearly based on this notion of varna. Thus, savarna meant "belonging to the same varna," having the same real sound-substance. This was perhaps aided by the ancient usage of the word savarna "having similar appearance." Thus, /a/ was savarna with $/ \bar{a}\rangle$, since they had the same real sound-substance. But $/ \mathrm{k} /$ and $/ \mathrm{kh} /$ were not regarded to be savarnas, since they were not thought to belong to the same varna. There, the conception of varga "class of homorganic stops" and the conception of savargiya "belonging to the same varga" filled the gap. Thus, both the concepts, namely savarna and savargìya, function side by side in the Prātisaākhyas [Sec. 10.3. 4] . K. C. Chatterji (1948, p. 285) says that "originally 'savarna' appears to have been formed after 'samānāksara' and was, therefore, restricted to the simple vowels." This is difficult to justify. The term savarna also appears in the context of consonants in the Prātis̄âkhyas, and hence it is more appropriate to relate it to a basic . conception of varna.

The basic notion of savarna as founded on the notion of varna, was in a way vague. We find that the Prātisakakhyas and the Kâtantra adjust this background notion of savarna to their specific needs. Thus, as far as vowels are concerned, the RPr and APr restricted the notion of savarna to short and 
long $/ \mathrm{a} /, \mathrm{i} /, / \mathrm{u} /$ and $/ \mathrm{r} /$. The $\mathrm{TPr}$ omitted $/ \mathrm{r} / /$, while the Kantantra also added $/ 1 /$. This difference from system to system shows the degree of adjustment. Some of the Prātiśākhyas did use the term savarna in the context of consonants, but here it was used in the sense of identity of the varna. Thus $/ y /$ and $/ \tilde{y} /$ are savarnas with each other, while $/ \mathrm{k} /$ or $/ \hat{\mathrm{s}} / \mathrm{is}$ savarna only with itself.

13.5. Pānini thought in more sophisticated terms. He did not care if his terms were not self-explanatory, but his main purpose was to achieve more generalization and more compact expression for his rules. He re-examined the categories of varna and varga, and tried to cover both of these notions in a single generalization. Through this attempt came the expanded notion of savarña. Pānini defined his expanded notion of savarna in clear featural terms: identity of points of articulation and internal effort. He also gave specific solutions to problems such as unwanted nonhomogeneity of $/ \mathrm{a} /$ and $/ \overline{\mathrm{a}} /$, and unwanted homogeneity of certain vowels with spirants. It is possible that this expanded notion of savarna existed in pre-Pāninian times. Such a notion is seen in the Apisali -śiksā-sütras, and if these can be proved to belong to the pre-Paninian teacher Apisali, that would help us push this notion into pre-Pạninian antiquity. Pānini not only gave an expanded definition of savarna, he also gave the procedure of homogeneous-representation, which is more compact than the older conventions of affixation of -kāra, -varna and -varga.

13.6. Then came Kātyãyana, the Värttikakära. According to the tradition recorded in the Kathā -sarit-sāgara, he belonged to the Aindra School of Grammar. 438 That he belonged to a non-Pạninian tradition can be clearly seen from his terminology, which is identical with that of the Prātiśākhyas and the Kātantra. Kätyāyana had also come under a heavy philosophical influence of the early schools of the Mīmāmsā system, i.e. the schools of Vyāḍi and Vājapyāyana. Vyādi held the doctrine of vyakti -vāda or dravya -vāda "Individualism, " while Vājapyāyana held the opposite doctrine of ākrti -vāda "Universalism." Kātyāyana extensively refers to the linguistic and ontological theories 
of these two thinkers. Probably under the influence of Vãjapyāyana's theory of universals, Kātyāyana returned to the old conception of varna with a new philosophical interpretation. Instead of saying that $/ \mathrm{a} /, / \overline{\mathrm{a}} /$ and $/ \overline{\mathrm{a}} 3 /$ belong to the same varna, Kătyāyana said that they share the same universal $/ \mathrm{a} /$-ness, which is naturally expressed by any instance of it. Similarly, $/ y /$ and $/ \tilde{y} /$ are covered by the same universal. However, the universal of $/ \mathrm{k} /$ cannot cover $/ \mathrm{kh} /$ etc. Thus, the limitations of the conception of a universal are the same as those of the conception of varna. Both are equally impressionistic or a priori. Kātyāyana never gave an explicit definition of a sound-universal. With this conception, he attempted to partially replace the procedure of homogeneous-representation. It was not necessary for vowels and semi-vowels, but it was still necessary for stops. Thus, in a way, Kătyāyana returned to the old distinction of varna and varga.

13.7. These were the three major directions in the development of the notion of savarna and its implementation. Each of the later schools of grammar chose one of these for its model, and some chose to combine them in varying degrees. Thus, Candragomin accepted Kātyāyana's suggestion of universal-mention for vowels, and adopted the notion of varga for stops. Thus, he tried to get rid of the notion of savarna. Sāākațāyana also followed Kātyāyana's universalmention, but he also defined savarṇa, like Pānini, and reserved homogeneous-representation for stops. The grammars of Devanandin and Bhoja are very closely related to Pānini's scheme. Hemacandra and Malayagiri defined savarna like Pānini, but in its implementation they worked out a sȳnthesis of Pānini and the Kātantra system. The Sārasvata mostly followed the Kātantra, except in a few cases where it uses the term savarna in the Pāninian sense. The Mugdhabodha gave an independent definition of savarna, but this definition reflects a synthesis of Pannini and the Kătantra. The Palli grammars followed the Kătantra in their usage of the term savanna. The VPr probably came under the influence of the Päninian system, in its definition of savarna, but its implementation is not different from the other Prātiśākhyas. This complex historical development 
and relationships can be seen in the following diagram:

\section{Historical Development of}

\section{Savarna}

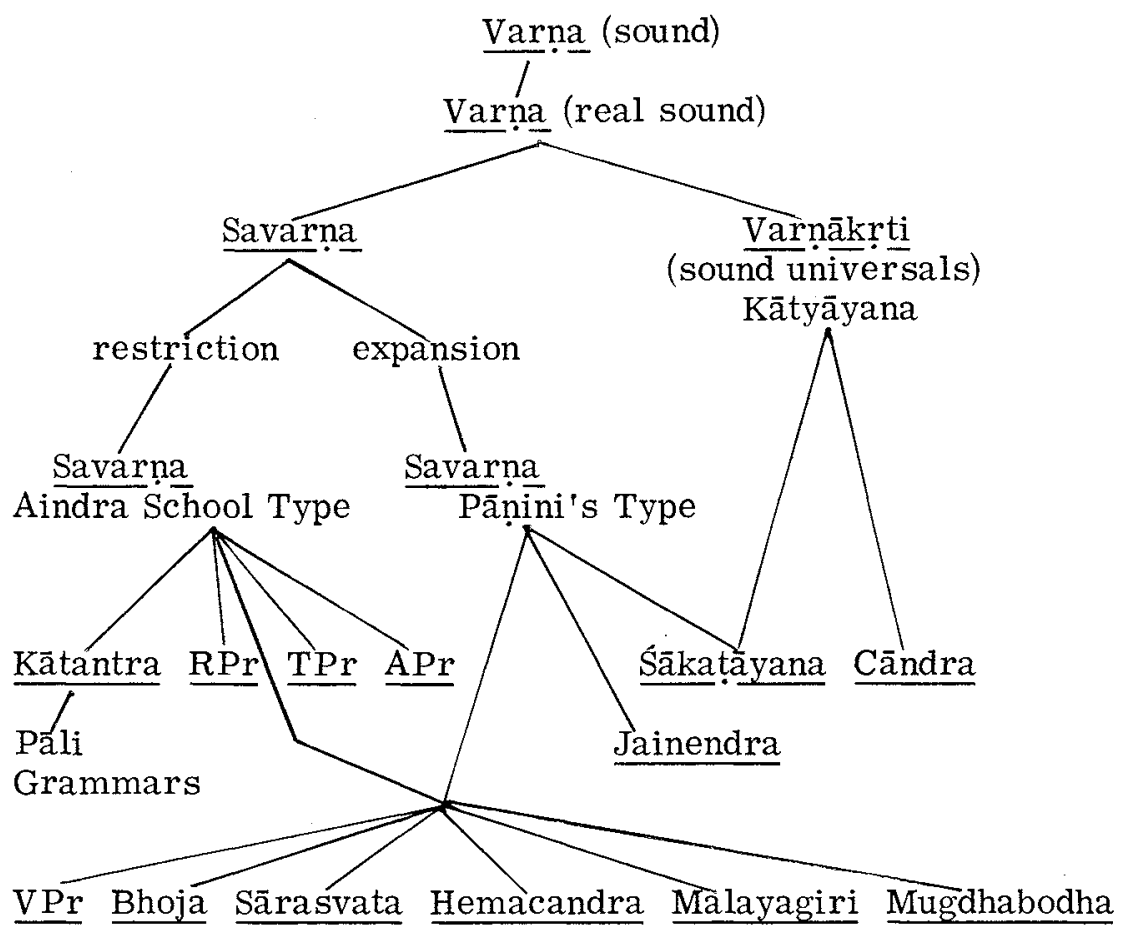

13.8. Thus, the historical development of this conception and its implementation represents a continuous process of rethinking, reformulation and re-examination at each stage. It shows the continued vitality of grammatical reasoning in the traditions of Indian grammar. Kielhorn rightly observed: "It was indeed difficult for later grammarians to add to the store of knowledge which had been collected by Pānini, Kätyāyana and Patañjali; nevertheless there has been no lack of scholars who have endeavoured to improve on the 
arrangement of the Așțādhyāyĩ, and who, each in his way, have done useful work. " ["On the Jainendra -Vyākarana," Indian Antiquary, Vol. 10, March 1881, p. 76.] The linguistic and methodological significance of the postPăninian grammars was also pointed out by Kielhorn: "Their aim was not to adapt the rules of those that went before them to the changed conditions of the language, but mainly, each after his own fashion to rearrange those rules, and to alter their wording and terminology." ["A Brief Account of Hemachandra's Sanskrit Grammar," Wiener Zeitschrift, Vol. 2, 1888, p. 18.] No system ever lived in a total vacuum, and hence each system is a product of its history. The notion of homogeneity is only one instance of this historical process. Only through a number of such studies, covering the entire span of grammatical activity, will we come to possess a complete history of the development of the Indian Grammatical Theories. 


\section{$\underline{\text { APPENDIX }} \underline{A}$ \\ THE SCOPE OF SAVARNA-GRAHANA}

[In this appendix, I shall present the arguments, which I have already discussed in my article "The Scope of Homogeneous-Representation in Pānini, "which is due to appear in the Silver Jubilee Volume of the Annals of Oriental Research, University of Madras. I addressed myself to this issue after the main body of this book was already completed. However, this is a very crucial question and hence this appendix has been added. ]

1. In his Śiva -sūtras, Pānini uses the marker $/ \mathrm{N} /$ twice, i.e. in $[1] \bar{a}-i-u_{1}-N_{1}$ and in $[6] 1(a)-N_{2}$. By P.1.1.71 (ādir antyena sahetā), an initial sound given along with a marker stands for itself and for the intervening sounds, excluding the marker sounds. The first six Śiva-sūtras are as follows:

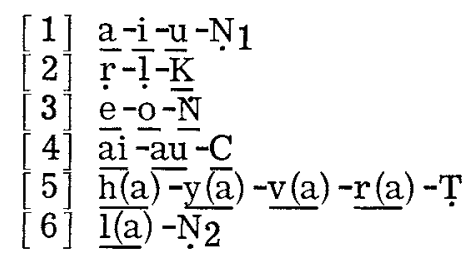

There are about forty shortforms made by using the Sivasūtras, and very rarely there is any confusion as to what sounds are included in those shortforms. But the shortforms $/ \mathrm{a}-\mathrm{N} /$ and $/ \mathrm{i}-\mathrm{N} /$ which are used by Pānini very frequently do present problems, because the marker $/ \mathrm{N} /$ is given twice in the Siva-sütras. Theoretically, /a-N/ and $/ \mathrm{i}-\mathrm{N} /$ could have two meanings each, depending whether $/ \mathrm{N} /$ belongs to a $-\underline{i}-\underline{u}-N_{1}$ or to $\underline{1(a)}-N_{2}$. 
2. Vyädi presents this problem in his Paribhāsa-sūcana and says that Paninini deliberately used the marker $/ \bar{N} /$ twice and that a confusion should not obstruct us, and we should rely on the tradition of interpretation for the specific significance of a shortform. Unfortunately, Vyādi only presents the problem and refers us to interpretative tradition, but does not state the conclusions in the case of $/ \mathrm{a}-\mathrm{N} /$ and $/ \mathrm{i}-\mathrm{N} /$ [Paribhāșā-sücana, p. 26-7] . The specific attempt to define the scope of $/ \mathrm{a}-\mathrm{N} /$ and $/ \mathrm{i}-\mathrm{N} /$ is seen for the first time in the versified vărttikas quoted by Patañjali. The authorship of these vârttikas is not yet clearly known, but they certainly seem to be pre-Patañjali. The Śloka-vārttika says:

Without any doubt [/a $-\mathrm{N} /$ is formed with the first / $\mathrm{N} /]$ because the following [ sounds] do not appear [in the examples of rules with $/ \mathrm{a}-\mathrm{N} /],[$ except] in P.1.1.69, [where] /a-N/ [is formed with the second / N/], because $[/ \mathrm{r} /$ is $]$ followed by the marker $/ \mathrm{T} /[$ in the rule] P.7.4.7 (ur r.t). The shortform $/ \mathrm{i}-\mathrm{N} /$ is [always] with the second $/ \mathrm{N} /$, since elsewhere $/ \mathrm{i} /$ and $/ \mathrm{u} /$ are [given separately, and not by the shortform $/ \mathrm{i}-\mathrm{N} /]^{4} 439$

Patañjali says that by using the marker / $\mathbf{N} /$ twice, Pānini indicates the maxim that one should not consider a rule to be inoperative because of doubt, but one should understand the specific meaning from the interpretation of the learned. 440 Patañjali clearly says that except in P.1.1.69, the shortform $/ a-N /$ is always with the first $/ \mathrm{N} /$, and that the shortform $/ i-\dot{N} /$ is always with the second $/ N / .441$ Thus, according to the tradition, the procedure of homogeneous -representation (savarna-grahana) applies to vowels and semi-vowels as they are given in the Siva-suttras, and to sounds marked with $/ \mathrm{U} /$.

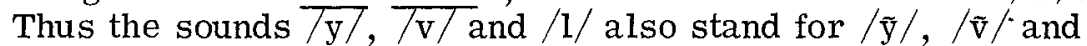
$/ \tilde{1} /$, and $/ \mathrm{r} /$ stands for $/ \overline{\mathbf{r}} /$ and $/ \overline{\mathrm{r}} 3 /$. Homogeneousrepresentation goes beyond a $-\mathbf{i}-\mathrm{u}-\mathrm{N}$. This also seems to be the view of Kātyāyana. 442 The later Päninian tradition follows the verdict of Patañjali.

3. Kunhan Raja has pointed out several problems in the traditional view about the scope of /a $-\mathrm{N} /$ in P.1.1.69. 
The first problem concerns the diphthongs:

There are the sounds /e/ and /ai/ which have the same place of articulation and the same effort in production. There is a similar relation between $/ \mathrm{o} /$ and $/ \mathrm{au} /$. Therefore $/ \mathrm{e} /$ and $/ \mathrm{ai} /$ become mutually concordant and /o/ and /au/also become mutually concordant in the same way. If the combination /a $-\mathrm{N} /$ in this sutra (P. 1.1.69) has the second $/ \mathrm{N} /$ as its final mute, the combination will include the diphthongs and consequently, when Pănini uses the sound $/ \mathrm{e} /$ and $/ \mathrm{o} /$, it includes also the sounds/ai/or/au/, just as the sound /a/means both the short $/ a /$ and the long $/ \bar{a} /$. This is not acceptable. This leads us to the assumption of another rule that as an exception, there is no concordance between /e/ and /ai/ or between /o/ and /au/. Such an exception is taken to be implied by the fact that while he does not include the long forms of the simple vowels, he gives all the four diphthongs separately. But all such difficulties can be avoided if even in this sutra /an/ is taken as combined with the first $/ \mathrm{n} /$ as mute as in the other sutras. 443

This objection assumes that according to Pānini /e/ and /o/ are homogeneous with $/ \mathrm{ai} /$ and $/ \mathrm{au} /$, and then there might be the problem of $/ \mathrm{e} /$ and $/ \mathrm{o} /$ standing for $/ \mathrm{ai} /$ and $/ \mathrm{au} /$, and vice versa.

4. Kunhan Raja tries to point out that $/ \mathrm{r} /$ need not stand for $/ \overline{\mathrm{r}} /$. The rule he considers is P.6.1.101 (akah savarne dirghah). This rule says that if an $/ \mathrm{a}-\mathrm{K} / \mathrm{sound}$ is followed by a homogeneous sound, both are replaced by a homogeneous long sound. Kunhan Raja comments:

...the short $/ \mathrm{r} /$ can never be followed by a long $/ \overline{\mathrm{r}} /$; there is also no possibility of a long $/ \overline{\mathrm{r}} /$ sound being followed by a short $/ \mathbf{r} /$ sound, in the way in which a short $/ a /$ can follow a long $/ \bar{a} / \ldots$. An example like hotr $-\bar{r} k$ ârah is only an artificially manipulated one. 444 
He also considers the rule P. 8.4.58 (anusvārasya yayi parasavarnah) which says that $/ \dot{\mathrm{m}} /$, if followed by a $/ \mathrm{y}(\mathrm{a})-\mathrm{Y} /$ sound [i.e. semi-vowels and stops] changes into a sound homogeneous with the following. Raja says:

All that is said in the sutra is that the anusvāra becomes a savarna of the following sound, retaining its nasal character. 445

Kunhan Raja holds that this rule requires $/ y /, / v /$ and $/ 1 /$ to be homogeneous with $/ \tilde{\mathrm{y}} /, / \tilde{\mathrm{v}} /$ and $/ \tilde{\mathrm{l}} /$, but not to stand for them.

5. With these arguments, Kunhan Raja concludes as follows:

That Pānini used the same sound / $\mathrm{n} /$ twice is unhappy. But we can say that of the two combinations possible with this mute one with the first letter /a/ is with the first mute $/ \mathbf{n} /$ and one with the second letter $/ \mathrm{i} /$ is with the second $/ \mathrm{n} /$. But to say that even here, there is an exception, not specifically mentioned by Pānini, is a position which I feel very difficult to accept.... In this context, the question is not whether a semi-vowel has a savarna or not; the point is whether when Pānini gives the semi-vowels, he includes the nasalised form of the semi-vowels also in it.... What is meant is simply this that when Pänini gives the short $/ \mathbf{r} /$ sound or the semi-vowels, they do not include the savarnas also. 446

Kunhan Raja has rightly separated the two questions: Does a given sound have any homogeneous sounds? Can a given sound stand for its homogeneous sounds? However, his general conclusion needs to be critically examined.

6. Raja says that /e/ and /ai/ are homogeneous, since their "place of articulation is throat-cum-palat and effort is vivrta (open). "447 Similarly, /o/ and /au/are homogeneous, since their "place of articulation is throat-cum-lip and effort is vivrta (open). "448 Here K. Raja is clearly following the phonetic description as given by such late texts as the 
Siddhānta-kaumudí of Bhațtoji Dikșita. 449

Historically speaking, we do not know exactly what kind of phonetic classifications were there in Pānini's mind when he gave his rules. We have to rely on secondary sources. The dates of the different versions of the Panniniyasikșā are not very clear, and they seem to be relatively of a late date. There are some subtle indications in Pānini's rules which suggest that he treated /e/ and /o/ quite differently from $/ \mathrm{ai} /$ and $/ \mathrm{au} /$. P.8.2.106 (plutāv aica idutau) says that when /ai/ and /ai/ become pluta "extra-long," it is the /i/ and $/ \mathrm{u} /$ in these sounds that becomes extra-long, and not the /a/ element. This clearly shows that, for Pānini, the sounds /ai/ and /au/ had distinctly two components. By contrast we may infer that the sounds /e/ and /o/ did not have such distinct elements. [Ref. : Bare (1975), pp. 185-93.]

Looking at the vārttikas of Kātyāyana, we find that he clearly distinguishes /e/ and /o/ from $/ \mathrm{ai} /$ and $/ \mathrm{au} /$. The varttika 4 on $P: 1.1 .48$ says that $/ \mathrm{i} /$ and $/ \mathrm{e} /$ are sasthāna "having the same point of articulation," and the same is true of $/ \mathbf{u} /$ and $/ \% / .450$ On the other hand, the vārttika 5 on P.1.1.48 says that in /ai/and /au/, the latter elements, i.e. $/ \mathrm{i} /$ and $/ \mathrm{u} /$, are longer segments, compared to the initial $/ \mathrm{a} / .451$ Thus, Kātyāyana seems to hold that $/ \mathrm{e} /$ is palatal, /o/ is labial, /ai/is throatal-palatal and /au/ is throatal-labial. Kätyayyana also says that the diphthongs are more open as compared to simple vowels. 452

Patañjali says that the element $/ \mathrm{a} /$ in $/ \mathrm{e} /$ and $/ \mathrm{o} /$ is quite indistinct, while / ai / and / au/ contain a vivrta-tara "more open"/a/vowel. He further says that /e/and $/ a u$ / cannot be savarna "homogeneous," because they are not tulya-sthāna "with the same point(s) of articulation." The sounds $/ \mathrm{e} / \mathrm{h} / \mathrm{o}, \mathrm{ai} / \mathrm{and} / \mathrm{au} / \mathrm{are}$ all sandhy -aksaras "diphthongs" but, in contrast to /e/ and /o/, the sounds /ai/ and /au/are described by Patañjali as being samāhāra-varnas "composite sounds," where there is a mātrā "mora" of $7 \mathrm{a} /$, and the other mora is of $/ \mathrm{i} / \mathrm{and} / \mathrm{u} / \mathrm{respectively.} 453$ This slightly differs from Kātyāyana's point of view concerning proportions of these elements. 
This shows that at the early stage of the Panninian tradition, the sounds $/ \mathrm{e} /$ and /o/ were looked upon as having one point of articulation, while /ai/ and /au/ were the real composite sounds with double points of articulation. All diphthongs are held to be more open than the simple vowels. This picture has been confirmed by a perusal of the Prātiśākhyas. 454 The Pāninina -śikșā, in different versions, represents views of a later period, and cannot be taken as representing the views of pannini. 455 Thus, there is no reason to believe that Pānini held /e/ and /o/ to be homogeneous with /ai/ and /au/.

7. The second argument of Kunhan Raja is that $/ \mathrm{r} /$ in Pānini's rules need not stand for $/ \overline{\hat{r}} /$. In twenty-five rules, Pannini gives short $/ \mathrm{r} /$ with the marker $/ \mathrm{T} /$, while $/ \overrightarrow{\mathrm{r}} /$ is given with the marker $/ \mathrm{T} /$ in several rules. The short $/ \mathrm{r} /$ is given also without $/ \mathrm{T} /$ in several rules. 456 The presence and absence of the marker $/ \mathrm{T} /$ is closely connected with the application of homogeneous-representation. The marker $/ \mathrm{T} /$ with $/ \mathrm{r} /$ or $/ \overrightarrow{\mathrm{r}} /$ is not really a conclusive proof that $/ \mathrm{a}-\mathrm{N} /$ in P.1.1.69 includes $/ \mathrm{r} /$, since the marker $/ \mathrm{T} /$ is also used with non-/a $-\mathrm{N} /$ sounds like $/ \overline{\mathrm{a}} /$ and $/ \overline{\mathrm{I}} /$ in a prescriptive function (vidhãyaka -taparakarana), as opposed to its restrictive function (niyāmaka taparakarana) in the case of $/ \mathrm{a}-\mathrm{N} /$ sounds. Wihtout $/ \mathrm{T} / \mathrm{a}$ non-/a-N $/$ sound stands just for itself, while with it, it can cover homogeneous varities of the same quantity. 457

However, there are cases of $/ \mathbf{r} /$ without $/ \mathrm{T} /$, where representation of $/ \bar{r} /$ is absolutely necessary. P.1.2.12 (uś ca), where /uh/ is genitive singular of $/ \mathbf{r} /$, applies to verb-roots ending in $/ \mathbf{r} /$ and $/ \overline{\mathbf{r}} /$ both, giving formations such

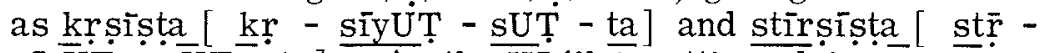

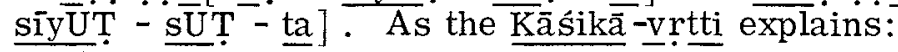

The marker $/ \mathrm{T} /$ is attached to [ the substitute $/ \mathrm{r} /$ in P.7.4.7 (ur rt)] , so that even in the place of a long substituendum $[/ \overline{\mathbf{r}} /]$, the short $[/ \mathrm{r} /]$ alone would be effected as the substitute. For example: acikrtat. 458 
P.3.2.171 (ād-r -gama -hana -janah kikinau lit ca) applies to roots ending in $/ \mathrm{r} /$ and $\overline{\mathrm{r}} /$, and yields formations like cakri

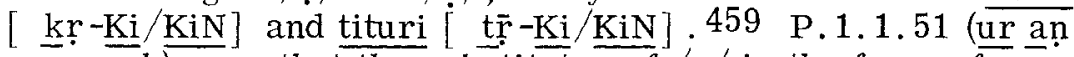
ra-parah) says that the substitutes of $/ \mathrm{r} /$ in the form of Ta/-vowels, /i/-vowels and /u/-vowels are followed immediately by $/ \mathrm{r} /$. This needs to apply not only to the substitutes of short $/ \mathrm{r} /$, but also to the substitutes of the long $/ \overline{\mathrm{r}} /[$ e.g. P. 7.1.100 (r. The se examples conclusively prove that $/ \mathbf{r} /$ in Panini needs to stand for $/ \bar{r} /$ also, and hence the scope of $/ \mathrm{a}-\mathrm{N} /$ in P.1.1.69 could not have been limited to a- $-\mathrm{i}-\mathrm{u}-\mathrm{N}$.

8. Thus, there is no doubt that the shortform /a-N/ extends up to the second $/ \mathrm{N} /$, in P.1.1.69. The question whether $/ \mathrm{y} /, / \mathrm{v} /$ and $/ \mathrm{l} /$ need to stand for $/ \tilde{\mathrm{y}} /, / \tilde{\mathrm{v}} /$ and $/ \tilde{\mathrm{l}} / \mathrm{is}$, as we shall see, a far more complex question, and needs much deeper attention than was given by Kunhan Raja. There are the following considerations:

Prima-Facie Argument [A]. If $/ \mathrm{y} /, / \mathrm{v} /$ and $/ 1 /$ do not represent $/ \tilde{y} / \overline{\mathrm{V} /} /$ and $/ \tilde{1} /$, then these nasal semi-vowels will not be designated as $/ \mathrm{h}(\mathrm{a})-\mathrm{L} /$. P.1.1.7 (halo nantarāh. samyogah) says that two $/ \mathrm{h}(\mathrm{a})-\mathrm{L} / \mathrm{sound}$ without a gap are called samyoga "cluster." Thus, the sequences like / $\tilde{y} y /$, $/ \tilde{\mathrm{V}} /$ and / $/ 1 /$ will not be legally clusters. This could create several problems. For this reason, we might say that $/ y /$, $/ \mathrm{v} /$ and $/ \mathrm{l} /$ must stand for $/ \tilde{\mathrm{y}} /, / \tilde{\mathrm{v}} /$ and $/ \tilde{\mathrm{l}} /$ also.

This argument is not really valid. The nasal $/ \tilde{y} /$, $/ \bar{v} /$ and $/ \tilde{I} /$ in cases like saỹyantā are obtained by P. 8.4.58 (anusvārasya yayi para-savarnahn) from $/ \dot{\mathrm{m}} /$, which is itself obtained from $/ \mathrm{m} /$ by P.8.3.23 (mo'nusvārah). P. 8.4.59 (vā padāntasya) makes P. 8.4.58 optional, if $/ \mathrm{m} /$ is at the end of a pada "finished word." The question is as follows. Is $/ \tilde{y} /$ derived by P. 8.4.58 to be treated as siddha "effected" for P.1.1.7 (halo'nantarāh samyogah), which defines two or more immediate/ha-L/ sounds as a samyoga "cluster ?" By P. 8.2.1 (pūrvatrāsiddham), rules in the Tripādī, last three quarters of the Astăandhyayí, are to be treated as if asiddha "not effected," for the rest of the grammar. Even within these last three quarters, a rule is to be considered 
to be asiddha "not effected" with respect to all the preceding rules.

In the present case, we have to go into still more details. On P. 8.2.1, Patañjali says that the samjñă-sūtrás [designation-rules] and the paribhāșā-sūtras [maxims of interpretation] apply wherever their conditions of application are found. These rules operate even with respect to the asiddha -section. [naișa dosah/ yady apidam tatrāsiddham, tat tv iha siddham kathām/ kārya-kālam samijñā-paribhāșam, yatra kāryam tatropasthitam drasttavyam, MB, Vol. III, p. 354-5; kārya-kāla-pakșe tu tripādyām apy upasthitir iti viśssah, paribhāsenduśekhara, ed. by K. V. Abhyankar, Pt. I, Poona, 1962, p. 2.] This might lead us to think that $/ \tilde{y} /$ derived by P. 8.4.58 is siddha "effected" for the samjñā-rule P.1.1.7. However, I think the situation is different. Patañajli's discussion indicates that if a samjnãa "technical term" is found in a Tripādi-rule, then the respective rule defining that technical term has to apply with respect to that Tripädi-rule. In such a case, whatever rules are siddha "effected" with respect to that particular Tripāiirule are also to be treated siddha with respect to that samjñarule. [The case of the term pragrhya is discussed by Nãgeśa, see: Paribhāsenduśekhara, pp. 3-4.] No rule after P. 8.4.58 uses the term samyoga or any other term dependent on the term samyoga. Therefore, P. 8. 4.58 cannot be siddha "effected" for P.1.1.7 in any way. Hence, in the place of the sequences $/ \tilde{y} y /, / \tilde{v} /$ and $/ \tilde{1} \mathrm{l} /$, P.1.1.7 finds $/ \mathrm{my} /$, $/ \mathrm{mv} /$ and $/ \mathrm{ml} /$, which are eligible to be termed samyoga. This is the original picture in the system of Pannini. Thus, $/ \tilde{\mathrm{y}} /, / \tilde{\mathrm{v}} /$ and $/ \tilde{\mathrm{I}} /$ need not be covered by $/ \mathrm{y} /, / \dot{\mathrm{v}} /$ and $/ \mathrm{l} /$ in $/$ ha $-\mathrm{L} /$ in $\mathrm{P} .1 .1 .7$.

The Pāninian system has to work this way. For instance, in a case like supinsu, the sequence / hs / cannot become a samyoga "cluster, $" \overrightarrow{\text { if }} / \mathrm{h} /$ derived by $\mathrm{P}$. 8.2.66 (sasajuso ruh) and P. 8.3.15 (khar-avasanayor visarjaniyah) is siddha for P.1.1.7 (halo'nantarăh samyogah). The sound $/ \mathrm{h} /$ is not a /ha-L/ sound in the original system of Pānini. Actually, $/ \mathrm{h} /$ is asiddha with respect to $\mathrm{P} .1 .1 .7$, and hence the rule P.1.1. 7 finds $/ \mathrm{s} /$ in the place of $/ \mathrm{h} /$, consequently 
making /ss / a real samyoga. The same has to be the case for sequences of an anusvãra and a consonant. The anusvāra effected by a rule like P.8.2. 23 (mo'nusvārah) has to be asiddha for P.1.1.7, so that there can be a samyoga in terms of the original $/ \mathrm{m} /$ or $/ \mathrm{n} /$ and the following consonant. Only with such a procedure can we explain why Pānini did not feel it necessary to include the ayogavāhas in the Śiva-sütras.

However, in one context, Patañjali seems to accept $/ \tilde{y} y /, / \tilde{\mathrm{v}} /$ and $/ \tilde{\mathrm{ll}} /$ to be samyogas, by saying that $/ \mathrm{y} /, / \mathrm{v} /$ and $/ 1 /$ stand for $/ \tilde{y} /, / \tilde{v} /$ and $/ \tilde{l} /$, implying thereby that they are /ha-L/ sounds, thus making/yy/ etc. real samyogas. 460 Considering the above given arguments, we may regard this passage in Patañjali as not reflecting the exact Pāninian procedure. As we shall see later on, Patañjali has accepted a vārttika of Kātyāyana, which proposes to regard $/ \bar{y} /$ etc. to be siddha "effected" in the context of rules of doubling (dvirvacana).

Prima-Facie Argument [B]. If $/ y /, / v /$ and $/ \mathrm{l} /$ do not stand for their nasal counterparts, then these nasal semi-vowels' will not be included in a pratyāhāra "shortform" such as $/ y(a)-R /$. Thus a rule like P.8.4.47 (anaci ca, yarah from P. 8. 4. 45) will not apply to sequences such as $-/ \tilde{y y} /-$. This rule says that $a / y(a)-R /$ sound preceded by a vowel and not followed by a vowel is optionally doubled. For this reason, we would want to include $/ \tilde{y} /, / \tilde{v} /$ and $/ \tilde{I} /$ in $/ y(a)-R /$ through $/ \mathrm{y} /, \mathrm{v} /$ and $/ 1 /$.

This argument is also full of problems. The sound $/ \mathrm{m} /$ is changed to $/ \dot{\mathrm{m}} /$ by P. 8.3.23 (mo'nusvārah), while this anusvāra is changed to a nasal semi-vowel by P. 8.4.58 (anusvārasya yayi parasavarṇah). However, the rule for doubling, i.e. P. 8.4.47 (anaci ca) stands in between these two rules, so that for this rule the nasal semi-vowel is as if non-effected (asiddha), while only $/ \dot{\mathrm{m}} /$ is effected (siddha). Hence it is not included in $/ y(a)-R /$, and hence cannot be doubled by P. 8.4.47. Kātyāyana goes ahead and makes several suggestions. He proposes to include anusvāra in the Siva-sūtras, as well as he proposes that for the sake of doubling para-savarna "substitute homogeneous with the 
following" should be regarded as siddha "effected."461 This creates several possibilities. Either an anusvāra could be doubled, or a nasal $/ \tilde{y} /$ etc. could be doubled by regarding it to be a / $(a)-R /$ sound. However, we are not sure if these provisos are intended by Pānini.

Prima-Facie Argument [ $\underline{\mathrm{C}}]$. By P.8.4.57 (ano'pragrhyasyānunāsiko vā) a word-final /a/-vowel, /i/-vowel or u/-vowel is optionally nasalized, if the word is not a pragrhya. Thus, we may optionally have nadi or nadĩ Suppose that nadî is followed by atra, would the nasal $/ \tilde{i}$ / change into a nasal / $\tilde{y} /$ by P.6.1.77 (iko yan aci) ? In such a case, we may want $/ y(a)-N /$ to include the nasal semivowels also.

This is also a dubious argument. The nasal final vowels are obtained by $P$ 8.4.57, which belongs to the last three quarters. Therefore, for P.6.1.77, the nasal $/ \tilde{1} /$ is still considered to be non-effected (asiddha), and hence we cannot get nasal $/ \tilde{y} /$ any way.

9. The evidence considered so far for inclusion of semivowels in /a-N/ in P.1.1.69 is quite inconclusive. At this stage, we should refer to Patañjali who has raised this exact question, and it is of historical importance to see how he struggles to find a purpose for this inclusion. What follows is a translation of the relevant passages from Patañjali's Mahābhāsya:

[A] Question:

For what purpose the semi-vowels have been included in $/ \mathrm{a}-\mathrm{N} /$ [ in P.1.1.69 (an-udit savarnasya cāpratyayaḥ) ] ?

[B] Explanation of the Purpose:

In [the examples] saỹyantā, sarvatsarah, yañlokam and taIlokam, the [substitutes] homogeneous with the following [i.e. $/ \tilde{y} /, / \tilde{v} /$ and $/ \tilde{I} /$, effected by P. 8.4.58 (anusvārasya yayi parasavarnah)] are regarded as being non-effected (asiddha) [ for P. 8.4.47 (anaci ca) and hence] only the anusvāra $[\dot{i} . \mathrm{e} . / \dot{\mathrm{m}} /]$ 
is doubled [by P.8.4.47]. Thus, [in the expressions sammyantā, sammiatsarah, yamminlokam and

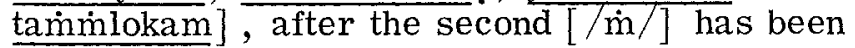
[substituted] by a sound homogeneous with the following [i.e. after having obtained samĩyantā, sam̄̄vatsarah, yamilokam and tamllokam by P.8.4.58], those $[/ \bar{y} /$, $\tilde{\tilde{v} / \text { and } / \Gamma /]}$ should be represented by $[/ \mathrm{y} / \mathrm{h} / \mathrm{v} /$ and $/ 1 /$ in $] / y(a)-Y /[$ in P. 8.4.58]. This would finally allow application of P.8.4.58 to the first $[/ \mathrm{m} /$, yielding saỹyyantāa, saṽvvatsarah, taIllokam and yalliokam]."

[C] Objection:

That is not the purpose. [Kātyāyana] will say later [on P.8.2.6] : 'In effecting doubling, a substitute homogeneous with the following (para-savarna) should be considered effected (siddha).' Since [ such a substitute] is said to be effected, it would remain so [and will not be considered to be $/ \dot{\mathrm{m}} /]$.

[D] Reiteration of the Purpose:

In that case, when a substitute homogeneous with the following (para-savarna) is effected [i.e. $/ \tilde{y} /, / \tilde{\mathrm{v}} /$ and $/ \tilde{\mathrm{l}} /$, by P.8.4.58], that should be represented by $[/ \mathrm{y} / \mathrm{h} / \mathrm{v} /$ and $/ \mathrm{l} / \mathrm{in}] / \mathrm{y}(\mathrm{a})-\mathrm{R} /[$ in P. 8.4.47 (anaci ca yarah from P. 8.4.45], so that [by P.8.4.47] there could be doubling $[$ of $/ \tilde{y} /, / \tilde{\mathrm{v}} /$ and $/ \tilde{\mathrm{I}} /]$.

[E] Rejection of the Purpose:

Doubling $[\overline{\text { of }} / \tilde{\mathrm{y}} / \overline{, / \tilde{\mathrm{v}} / \text { and }} / \tau /]$ may not take place [by P.8.4.47 (anaci ca) ] .

[F] Reiteration of the Purpose:

[We need doubling of $/ \tilde{y} /, / \tilde{\mathrm{V}} /$ and $/ \tilde{\mathrm{I}} /$ by P.8.4.47], since there is a difference [in the resulting forms]. If there is doubling, the form [ saỹỹyantä] would have three $/ y /-s$. If there is no doubling, then the form [ saỹyantā] would have two $/ \mathrm{y} / \mathrm{-s}$.

[G] Rejection of the Purpose:

[Even if there is doubling], there is no difference 
[in the forms]. Even if there is doubling, the form [finally] contains only two $/ \mathrm{y} / \mathrm{-s}$. How could this be? By P. 8.4.64 (halo yamām yami lopah) one of the $/ y /-s$ will be deleted. [The rule says: A $/ y(a)-M /$ sound preceded by a consonant and followed by a corresponding $/ \mathrm{y}(\mathrm{a})-\mathrm{M} /$ sound is (optionally ?) deleted. ]

[H] Reiteration of the Purpose:

Still there is a difference. After doubling, the form might be with two $/ \mathrm{y} / \mathrm{-s}$ [if the deletion rule P. 8.4.64 applies], and it might be with three /y/-s [if P. 8.4.64 does not apply]. If doubling does not take place, then the form will have only two $/ y /-s$. How could such a difference not be there? [There will be no difference in the form] if the deletion rule [P. 8. 4.64] is obligatory. However, it is optional.

[ I ] Rejection of the Purpose:

Let [the rules] be in such a way that there is no difference [in forms].

[J] Reiteration of the Purpose:

Option must continue [in P. 8.4.65 (jharo jhari savarne) from P. 8.4.62 (jhayo ho'nyatara syām)] , since by P. 8.4.49 (śaro'ci), Pānini prohibits doubling. [P. 8. 4.65 means: $a / j h(a)-R /$ sound preceded by a consonant and followed by a homogeneous $/ \mathrm{jh}(\mathrm{a})-\mathrm{R} /$ sound is (optionally?) deleted. P.8.4.49 means: If followed by an $/ \mathrm{a}-\mathrm{C} / \mathrm{sound}$ (i.e. a vowel), a $/ \hat{\mathbf{s}}(\mathrm{a})-\mathrm{R} /(\mathrm{i} . \mathrm{e} . / \hat{\mathbf{s}} /, / \mathrm{s} /$ and $/ \mathrm{s} /$ ) is not doubled.] How is this indication [justified] ? [It is justified] because, if the deletion rule [i.e. P.8.4.65 (jharo jhari savarne) were obligatory, there would be no purpose in negation [of doubling by P. 8.4.49

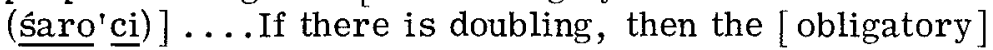
deletion by P. 8.4.65 would take place. The teacher realizes that the deletion is optional, and hence prescribes negation of doubling [in specific cases, by P. 8.4.49] . [Note: The implication is that if option continues from P. 8.4.62 to P. 8.4.65, it obviously continues through P. 8.4.64 (halo yamām yami lopah). 
Once this rule is optional, to derive a form such as saỹỹyantā with three $/ \mathrm{y} /-\mathrm{s}$, we need $/ \mathrm{y} / \mathrm{h} / \mathrm{v} /$ and $/ \mathrm{l} /$ to stand for $/ \tilde{y} /, / \tilde{\mathrm{V}} /$ and $/ \tilde{\mathrm{I}} /$ in P. 8.4.58 (anusvārasya yayi parasavarnah). Thus, this argument establishes the purpose. ]

[K] Rejection of the Purpose:

This is not a [justifiable] indication... Therefore, even if the deletion rule [i.e. P.8.4.65] is obligatory still the rule for negation [ of doubling, i.e. P. 8.4.49] must be given. [Note: We need not go into the arguments in this section. The argument consequently means that P. 8. 4.64 (halo yamäm yami lopah) must be obligatory, and ultimately would mean that $/ y /$, $/ \mathrm{v} /$ and $/ \mathrm{l} /$ need not stand for $/ \tilde{\mathrm{y}} /, / \tilde{\mathrm{v}} /$ and $/ \tilde{\mathrm{l}} /$. This is the objector's view.]

\section{[L] Patañjali's Conclusions:}

Thus, it is extremely unclear in Pānini's [ system] to the teachers, whether option continues or not. ${ }^{462}$

This is a statement of frustration on the part of Patanjali, a clear indication that there was probably no direct teacherstudent tradition linking Patañjali with Pānini. However, Patañjali accepts elsewhere that P. 8.4.64 (halo yamām yami lopah) is optional. 463 That would indicate that Patañjali accepts forms such as saỹỹyantā with triple clusters, which require that $/ \mathrm{y} /, / \mathrm{v} /$ and $/ 1 /$ should stand for $/ \tilde{y} /, / \tilde{\mathrm{v}} /$ and $\tilde{1} /$. The whole discussion shows that Patañjali was at great pains in justifying inclusion of semi-vowels in homogeneous representation, and finally he himself was not sure of the conclusions.

10. Looking at the whole argument we may sum it up as follows. There are three axioms:

(1) P. 8. 4.64 (halo yamām yami lopah) is optional.

(2) An anusvära can be duplicated by P. 8. 4.47 (anaci ca). This depends on inclusion of the anusvāra in the Siva-sūtras. This has been proposed by Kātyāyana and seems to have been accepted by Patañjali. 464 
(3) The parasavarna "substitute homogeneous with the following" effected by P. 8.4.58 needs to be considered as effected (siddha) for P. 8.4.47.465

Of these three axioms, we need either (1) and (2) or (1) and (3) to justify inclusion of semi-vowels in the rule P.1.1.69. It is impossible to establish with any certainty historical validity of any of the three axioms stated above. Patañjali himself has declared the uncertainty of the first, while the other two are suggestions of Kātyāyana.

11. Perhaps, Pānini's intention in the formulation of P.1.1.69 was for achieving a very wide morphophonemic generalization, of which different parts may have varying degrees of utility in his grammar. 466 It is possible that he constructed these meta-rules before conceiving the specific operation rules. Thus, certain elements in his meta-rules may have later remained unutilized. Traditionally, the only practical purpose is the doubling of nasal semi-vowels. It depends on P. 8. 4.64 being optional. Kaiyata says that though the argument for indication (jñāpaka) has fallen through, still the tradition of the Panininian teachers accepts P.8.4.64 to be optional. 467 Hari Dikșita in his Brhacchabdaratna says that the usage of /a $-\mathrm{N} /$ in P.1.1.69 itself is an indication that P. 8.4.64 is optional. If P.8.4.64 is not optional, then the purpose of $/ \mathrm{a}-\mathrm{N} /$ beyond the limit of $/ \mathrm{a}-\mathrm{C} /$ cannot be justified. 468 Năgeśa refutes this argument. 469 However, Hari Dikșita's argument alone can explain to some extent why Patañjali eventually considered P.8.4.64 to be optional.

12. There is no doubt that Kātyāyana, who presupposes that parasavarna "substitute homogeneous with the following" be considered effected (siddha) in the context of doubling, intends such a doubling and accepts clusters like / $\tilde{y} \bar{y} y /$, $/ \tilde{\mathrm{v}} \tilde{\mathrm{v}} /$ and $/ \mathbb{\Pi 1} / .470$ Patanjali and the later tradition accepts this notion. What is historically not certain is if Pānini himself accepted this. Pānini's rules as they stand do not allow such doubling. For the doubling rule P.8.4.47 (anaci ca),$/ \tilde{\mathrm{y}} /, / \tilde{\mathrm{v}} /$ and $/ \tilde{\mathrm{I}} /$ effected by P. 8.4.58 are non-effected (asiddha), while $/ \dot{\mathrm{m}} /$ effected by P.8.3.23 is effected (siddha). However, an anusvāra is not included in the Siva-sūtras. 
It is not $a / y(a)-R /$ sound and hence cannot be doubled. Thus, ultimately there is no doubling of nasal semi-vowels.

It is quite probable that Pānini himself never intended doubling of anusvāra and nasal semi-vowels. Thus, this may never have been the purpose for inclusion of semi-vowels in the rule P.1.1.69. If we look at the Prātiśākhyas, we find support for the view that there is no possibliity of clusters

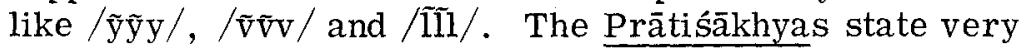
clearly that a consonant followed by a homogeneous consonant is not doubled. 471 There seems to be consensus of the Prātisāakhyas on this point. Under such circumstances, without any positive proof, it is hard to accept that Pannini allowed such doubling. It is not clear why Kătyāyana developed such a notion. It may be that this was his deductive attempt to find a practical purpose for inclusion of semi-vowels in P.1.1.69. Ultimately, we can only state that Pānini most certainly included semi -vowels in /a $-\mathrm{N} /$ in $\mathrm{P}$.1.1.69, but for what practical purpose, we do not know. 472 



\section{NOTES}

1. Kielhorn (1876a), p. 52, and also S. D. Joshi (1968), Intr. p. iv. We find a stong traditional assertion of this opinion in Maitreyarakșita's Tantrapradīpa: na hi bhāsyakāramatam anādṛtya sūtrakārasya kaścanābhiprāyo varnayitum yujyate / sūtrakāra-vārttikakā $\overline{\text { rābhyām tasyaiva prāmāṇya }}$ darśanāt ...uttarottarato bhāșyakāra syaiva prāmānyam, quoted by S. C. Chakravarti, Introduction to Dhātupradipa, pp. 2-3.

2. Belvalkar (1915), p. 35 .

3. For an example, see: Deshpande (1972), p. 233.

4. Thieme (1935a), p. x.

5. This traditional view is in fact quite a late notion, and most of the modern scholars now believe in Pānini's authorship of these sutras. The most recent and comprehensive study is: Cardona (1969).

6. For the discussions on this point by Kătyāyana and Patañjali, see: MB, Vol. I, Sec. I, p. 59 ff.

7. For a misinterpretation of this notion, see: "These sutras must be understood in such a way that the last consonant of each of them is the notational symbol for the preceding group: $/ \mathrm{n} /$ is the symbol of the short vowels, $/ \mathrm{k} /$ is the notational symbol of the sonatic liquids etc." Zgusta (1969), p. 405. This is obviously wrong.

8. Thieme (1935a), p. 101.

9. Burnell (1875), p. 22.

10. savarna -samjjñāyām bhainna -deśesv atiprasañah prayatna -sāmānyāt, Vārttika 2 on P.1.1.9, MB, Vol. I, Sec. I, p. 153 .

11. siddham tv āsye tulya-dèsa-prayatnam savarnam, Vārttika $\frac{2}{2}$ on P. 1.1 .9 , ibid. 
12. taddhitāntam āsyam/ āsye bhavami āsyam, "śarīāvayavād yat" kim punar ā sye bhavam? sthănam karanam ca/ $\mathrm{MB}$, Vol. I, Sec. I, p.154.

13. $\operatorname{VPr}$ (i. 43) samāna -sthāna -karanāsya -prayatnạ savarnah. Uvața's commentary says: ko'sāv äsyaprayatno nāma, samvrtatā vivṛtatā ca aspprstatā sprestatatā ca Ișat-sprștatā ardha -sprstata cety ā sya -prayatnah, $\overline{V P r}(\underline{W})$, pp. 118-9. The Varna-ratna-pradipikā-śiksa of Amareśa and the Yājñavalkya -sikșā also speak of these six types of internal efforts (āsya -prayatna), see: Śsiksāsamgraha, pp. 120 and 132 .

14. Breloer (1929), p. 116.

15. Thieme (1935a), p. 94. For a counter argument, see: Cardona (1965), p. 227.

16. Thieme $(1935 \mathrm{c})$, p. 22.

17. ibid.

18. See: "Varna ist anderseits auch nicht ein einzelner 'gesprochener Laut', noch auch ein 'Phonem', sondern bezeichnet eine Abstraktion, die keine linguistische Wirklichkeit hat: varna 'Farbe, Gattung' benennt speziell eine 'Lautgattung'. Z. B. avarna ist 'die Gattung der $/ \mathrm{a} /$-Laute (d.h. $/ \mathrm{a} /, / \overline{\mathrm{a}} /$ und $/ \overline{\mathrm{a}} 3 /)^{\prime}, \mathrm{z}$. B. $/ \mathrm{k} /, / \mathrm{kh} /, / \mathrm{g} /, / \mathrm{gh} /$ und $/ \mathrm{n} /$ sind savarna 'von gleicher Gattung', weil sie alle am Velum artikuliert werden." Thieme $(1957 \mathrm{c})$, p. 666.

19. bhedādhișthānā hi savarṇa-samjñā, yadi yatra sarvam samānam tatra syât, savarna-samjnā -vacanam anarthakam syāt/ $\mathrm{MB}$, Vol. I, Sec. I, p. 156 .

20. prayatna -viśesanam āsyopādānam/ santi hi āsyād bāhyāḥ prayatnāh h, te hāpitā bhavanti/teșu satsv asatsv api savarna-samijñā siddhā bhavati Tibid, 1. 153 .

21. nāsikāyāa āsyāntargatatve'pi mukha -nāsiketi sūtre nāsikātiriktāvayavaka -mukhasyaiva grahanena tatsāhacaryād atrāpy āsya -padena tādr śsasyaiva grahanam bodhyam/MB-P-U, Vol. I, Sec. I, p. 154.

22. anudit savarnasya iti sāāstram satah savarnasyāṇā 
grahanam bhavati ity etāvanmātram bodhayati, na tv aprasiddham savarnam kalpayati/, Ratnaprakāsa on MB, MPV, pp. $170-1$.

23. See: ākrtî-grahanāt siddham, Vārttika 13 on the Sivasütra 1, and also: avarnākrtir upadiștā sarvam avarnakūlam grahisyati, tathevarnākr tis tathovarnākrtih/ MB, Vol. I, Sec. I, p. 70 .

24. See: evañ ca krrtvā dharma-śāstram pravrttam 'brāhmano na hantavyah,'; 'surā na peye'ti, brāhmana -mātram ca na hanyate, surā -mātram ca na pĩyate/ yadi dravyam padārthah syād, ekam brāhmanam ahatvā, ekām ca surām apitvā anyatra kāma-cârah syä̀t $\overline{\mathrm{MB}}$, Vol. I, Sec. II, p. 92 .

25. See the Vārttikas: 1) hal-grahanesu ca, Vt 15 on the Siva -sūtra 1, MB, Vol. I, Sec. I, p. 71, and 2) tadvac ca hal-grahanesu, Vt on P.1.1.69, MB, Vol. I, Sec.I, p. 375. On this Vt, Bhartrhari comments: hal-grahanesu ca/ tatra grahanaka -śāstrasyāvyāpārah, MB-D̄, p. 57 . This statement of Bhartrhari that P.1.1. $\overline{69}$ does not apply to consonants needs some modification. P.1.1.69 does apply to $/ y /, / \mathrm{y} /$ and $/ 1 /$, which are included in the shortform $/ a-N /$. Only then these sounds can stand for $/ \tilde{\mathrm{y}} /, / \tilde{\mathrm{v}} /$ and $/ \tilde{\mathrm{I}} /$. If P.1.1.69 were meant to apply only to vowels, Pānini could have used the shortform $/ \mathrm{a}-\mathrm{C} /$ instead of $/ \mathrm{a}-\mathrm{N} /$.

26. savarne'n-grahanam aparibhāsyam ākrti -grahanāt, Vt on $\overline{\text { P.1.1. }} \cdot \overline{9}, \overline{\mathrm{MB}}, \overline{\mathrm{Vol}} . \overline{\mathrm{I}}$, Sec. I, p. $3 \overline{73}$.

27. Cardona (1968), p. 448.

28. See: "The Siva-sūtras at the beginning of Pãnini's grammar are sophisticated presentation of Sanskrit sounds, but not a complete list, because, e.g. /a/ stands not only for $/ \mathrm{a} /$, but also for $/ \mathrm{a} /, / \mathrm{a} /, / \bar{a} /, / \hat{a} /$, $/ \bar{a} /, / \bar{a} 3 /$ etc., i.e. $/ \mathrm{a} /$ denotes the genus of $/ \mathrm{a} /$ sounds." Scharfe (1971), p. 7.

29. See: "It (i.e. /a/) stands for all its varieties 18 in number, Pat. avarnākrtir upadisțā sarvam avarnakulam grahisyati." Ghatage (1972), p. 158. Also see: "But there are some sounds lacking (in the Siva-sūtras), 
which cannot have been unknown to Pānini, first of all the long vowels $/ \overline{\mathrm{a}} /, / \overline{\mathrm{i}} /, / \overline{\mathrm{u}} /, \ldots$ Of course, the long vowels were known to the great grammarian: as a matter of fact they already appear in 1.1.1. vrddhir ādaic, or at least one of them, the long $/ \bar{a} /$. And the introduction to the Mahābhāsya tells us, that the long vowels are always, unless expressly otherwise stated, implied when mentioning short ones." Sköld (1926), p. 9. He also says: "Now, why do the long vowels not appear in the Siva-sutras? Already the Indian commentators explained this fact by stating, that in Pânini's work short vowels usually stand for the long ones also. And this opinion seems to have been unanimously accepted by Western scholars." Ibid., p. 21. The se scholars seem to blur the distinction between the two procedures of savarnagrahana and âkrti -grahana.

30. Biardeau (1964), p. 372.

31. an-grahanam kurvatah sütra -krto nāyam pakso'bhipretah, SKB, p. $3 \overline{6}$.

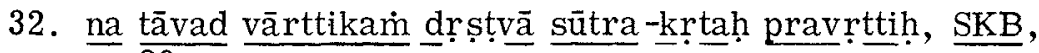
p. 39 .

33. atra... savarna -grahanam, jāti -nirdeśo vā, LSS, pp. 104-5, and also: sūtra -matenāha -savarneti, bhāsya -

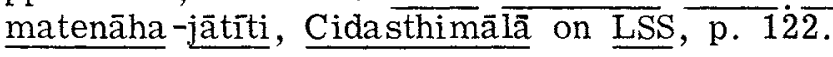

34. tat-sūtre jāti -pakșasyābhāvāc ca, Cidasthimālā on LSS, p. 104.

35. See the note: 23 .

36. ākrti -grahanāt tu siddham/pratyāhāre nuvrtti-nirdeśe ca jātir eva codyate na vyaktih/ vyakty -upādānam tu yathā nālikera-dvīpa -nivāsina idam upadiśnate-ayam gaur eșa tvayā na padā sprasțavya iti/sa tam bālami krșnam kr śam copadișto vroddham sabalam sthülam api na sprsati $\mathrm{MB}-\mathrm{D}, \mathrm{p} .5 \overline{7}$. Annambhatta tries to give some formal explanation of the perception of a universal like atva "/a/-ness" which is common to $/ \mathrm{a} /, / \overline{\mathrm{a}} /$ and $/ \overline{\mathrm{a}} 3 /$ : kevala -kanțhyatve sati svaratvam atva-jāter vyañjakam, tac ca dírgha-plutayor api samānam/, Uddyotana on $\overline{\mathrm{MB}}-\overline{\mathrm{P}}, \underline{\mathrm{MPV}}$, p. 115. 
37. asța-krtvo go-śabda uccarita iti vadanti/ nāstau gosabdä iti ...na hi te sadrśa iti pratíyanti, kin tarhi sa evāyam iti T... naisa vinastah yata enam punar upalabhāmahe/ "[The people] say that the word go 'cow' is uttered eight times, but they do not [say that] eight go-words [were uttered]. They do not think that [the second utterance] is similar [to the first], but [they understand the second] to be the same [as the first]. The [first sound] has not been destroyed, since we find the same sound [manifested] again." Säbara -bhāssya on MS, Vol. I, Part I, p. 87-9. Also: samyoga -vibhāgā nairantaryena kriyamānāh sabdam ä̉hivyañjanto nāda -śabda -vācyāh vrddhir na sabdasya, "The conjunctions and disjunctions [of the air] which are continuously produced are called nādas 'physical sounds' which manifest the [ real] sound. Therefore, this kind of prolonging etc. belongs to the physical sound and not to the real sound." Śäbara-bhāsya on MS, Vol. I, Part I, p. 84.

38. utpanno ga -kāro nașto ga -kāra iti pratityā varnānām anityatvāt 'so'yam gakāra' iti pratyabhijñāyāh seyam dipajvāletivat sājātyāvalambanatvāt, "The sounds are noneternal, since there are cognitions that the sound $/ \mathrm{g} /$ is produced and that it has been destroyed. Therefore, the recognition of the type 'this is that $/ \mathrm{g} /$-sound' rests on [two sounds] belonging to the same universal. This is similar to the cognition 'this is the same flame of the lamp." Dīpikā on TS, p. 54, also: KM, p. 851.

39. katvādikam tu dhvani -niștham, dhvani -viśseșa-vyaktayah

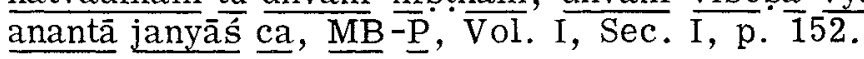

40. ișța-buddhy -arthaś ca varnānām upadeśah/ isțāān varnān bhotsyāmahe iti/ na hy anupadiśya varnān iștā varnāạ

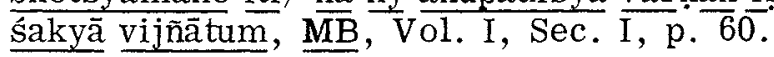

41. ișța-buddy -arthaś ceti ced udāttānudātta -svaritāanunāsika -dírgha -plutānām apy upadeśah, $\overline{\mathrm{Vt}}, \underline{\mathrm{MB}}$, Vol. I, Sec. I, p. 60 .

42. ākrty-upadeśāt siddham, Vt, avarnākrtir upadisțāa sarvam avarna-kulam grahisyati tathevarnākrtih tathovarnākrtih/ MB, Vol. I, Sec. I, p. 60 . 
43. ākrty -upadesāt siddham iti cet samvrtādinām pratiȘedhah, Vt., MB, Vol. I, Sec. I, p. 60. Patañjali mentions the following faults of the pronounciation of vowels: samvrta "closed pronounciation," kala "pronouncing a sound in a wrong point of articulation," dhmāta "a short vowel appearing long, because of using too much air," enikrta "an unfinished sound, which leaves doubt about its exact nature, " ambükrta "that which is heard as if not clearly coming out of the mouth," ardhaka "that which is heard with half of its regular quantity," grasta "unclear or suppressed at the root of the tongue," nirasta "harsh (Kaiyața), fast (Nāgeśa)," pragita "as if sung," upagita "affected by the tones of the nearing sounds, "ksvinna "trembling," romaśa "high sounding," avalambita "mixed with another sound," nirhata "too dry," sandasta "as if prolonged, "virkírna "extending into another sound." Patañjali says that consonants have different faults of pronounciation. The above explanations are based on the commentaries of Bhartrhari, Kaiyata and Nāgeŝa $[\underline{M B}-\underline{D}$, p. 43; $\underline{\mathrm{MB}}-\underline{\mathrm{P}}$ and $\underline{\mathrm{MB}}-\underline{\mathrm{P}}-\underline{\mathrm{U}}$, Vol. I, Sec. I, p. 60].

44. evận tarhi asțāâsadhā bhinnāmi nivrtta -kalādikām avarnasya prattyāpattiọ vakșāmi s sa tarhi vaktavyā, MB, Vol. I, Sec. I, p. $6 \overline{1 . ~ A l s o: ~ a k a ̄ r a s y a ~ n i d a r s ́ a-~}$ nārthatvāt sarva -varnānām sāastrānte prattyāpattir ity arthah, MB-P, and tathā ca prattyāpatty-āśrayane gauravam iti bhāvah, MB-P $-\underline{\mathrm{U}}$, Vol. I, Sec. I, p. 61 .

45. lingārthā tu prattyāpattih,$\underline{V t}$; yady apy etad ucyate, athavaitarhy anekam anubandha -śatam noccāryam, itsamjñ̄ā ca na vaktavyā, lopaś ca na vaktavyah/yad anubandhaih kriyate tat kalādibhih karisyate/ MB̈, Vol. I, Sec. I, p. 61. This has been elaborated by the commentators by showing how new rules could be formulated by using the faulty varieties of pronounciation. "For example, in order to show that a root is one of those with which occur the endings called a tmanepada, Pănini lists (in the appendix called Dhätu-pātha) consonantfinal roots with a final nasalized anudātta vowel, which by [A 1: upadeśe'j anunäsika it] is an it. Vowel-final roots are listed with a final $/ \overline{\mathrm{n}} /$ which is it by [A 2: 
hal antyam P.1.3.3] . Pānini then formulates a rule (1.3.12) anudātta -nita ātmanepadam 'The ātmanepada endings occur after roots marked with anudātta or $/ \dot{\mathrm{n}} /$. ' Now for 1.3.12, a new rule would be formulated: kaläd àtmanepadam 'After roots pronounced with kala...."." Cardona (1969), p. 10. For the original commentatorial discussions, see: $\underline{M B}-\underline{P}$ and $\underline{M B}-\underline{P}-\underline{U}$, Vol. I, Sec. I, p. 61 .

46. siddhyaty evam apāniniyam tu bhavati, MB, Vol. I, Sec. I, p. 61 .

47. [siddhānta -bhāṣyam] athavā idam tāvad ayam prasțavyah:

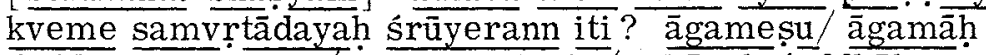
šddhāh pathyante/ vikäresu tarhi / vikārāh ś̉ sudhāh pathyante 7 pratyayeșu tarhi pratyayāh suddhāh pathyante/ dhātusu tarhi/ dhātavo'pi suddhāh pathyante/ prātipadikeșu tarhi / prātipadikāny api suddhāni pathyante/ yāni tarhy agrahanāni prātipadikāni etesām api svara -varnānupūrvi-

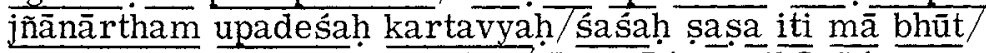
mañcako mañjaka iti mā bhūt āgamà ś ca vikārãś ca pratyayāh saha dhātubhih uccâryante tatas tesu neme prāptāh kalādayah $\overline{\mathrm{MB}}$, vol. I, Sec. I, p. 62 . The commentary Ratnaprakasa on the MB says that this reference to "unlisted nominals" also indirectly refers to unlisted verb-roots and affixes: dhātu-pratyayayor apathitayor upalaksanam idam, Ratnaprakāśa, MPV, p. 121 .

48. K. V. Abhyankar (1969), pp. 51-2. Also: "This is not to suggest that Pānini's grammar be remolded to list all nominal bases of the language. As Kaiyața says: nominal bases with unādi affixes and the nominal bases such as prșodara 'spotted-belly' are recognized as correct because they are used by the instructed. Hence, all are included in the grammar." Cardona (1969), p. 11. However, I think that here Patañjali is trying to demonstrate how the follower of universal-mention is finally cornered. He is faced with listing all the nominals in order to exclude the faulty pronounciations covered by universal-mention. Patañjali's expression upadeśą kartavyah. "listing would have to be made" is quite clear. Kãtyāyana was probably not aware that his proposal would 
lead to such consequences. Patañjali has lead the argument to its inevitable logical conclusion. In a different context, Patañjali clearly says that if one proposes to make a complete teaching of all unlisted and underived nominals, it would involve undesirable prolixity [yāny etāni prātipadikāny agrahanāni, tesā̄m etenābhyupāyenopade śaś codyate, tad guru bhavati, MB, Vol. I, Sec. I, p. 65. Also: pratipada -pāthasyāśakyatvāt, MB-P, and sarvāny agrahanāni prātipadikāni vivrutākārayuktāni pathanīyannity arthah $\ldots$ tad guru bhavati, tasmäd iti $\overline{M B}-\underline{P}-\underline{U}, \overline{V o l}$. I, Sec. I, p. 65]. Patañjali narrates a story that Brhaspati started teaching Indra, by listing all the words, but could not finish his instruction even within a thousand divine years. The sample of such a listing given by Patañjali is gaur aśvah purușo hasti Sakunir mrgo brāhmanah [MB, Vol. I, Sec. I, pp. 42-3] . This story indicates impossibility of listing all words. However, apparently there were some efforts in such a direction. Patañjali uses the term śabda -pārāyaṇa "a [full] listing of all words," and Bhartrhhari says that this is a conventionally established term and is the name of a work [ MB-D, p. 17] . Interestingly enough, the word näma -pārāyana occurs in the first verse of the Kâsika -vrrtti [Vol. I, p. 3] . The Nyāsa says that it is a work with which one can go to the end of nominalstems, while the Pada-mañjari explains this to be a work where the words listed in Pănini's gana-pātha are explained [ $\mathrm{KS}-\mathrm{N}$ and $\mathrm{KS}-\mathrm{P}$, Vol. I, p. 4]. In 1803, Colebrooke hinted at the possible existence of such voluminous texts ["On the Sanskrit and Prakrit Languages," Asiatic Researches 7, 1803; reprinted partially in Staal (1972), p. 42].

49. tasmān na śisța-prayogam antarenaitad bhavati kalādinivrttir upapanneti, MB-D, p. 46. Annambhatța says that the Bhāșya passage upadeśah kartavyah "teaching of [unlisted nominals] should be made" implies that such a teaching has not been done by Panini, and if all such nominals were to be listed; it would be a case of pratipada-pātha "a word by word listing" of all usages. That certainly could not be a solution (parihārānupapattih). Therefore, Kaiyata gives another explanation, i.e. one 
must rely on the usage of the Śistas. [ nanu upadesah kartavya ity uktyā sūtrakārenānupadisțatvāvagateh sarvesām upadeśāngikāre pratipada-pātha -prasañāat parihärānupapattị̂ ata āha śisța-prayuktatveneti/, Uddyotana, MPV, p. 110 .

50. yasya punar [varnaika -deśā varna -grahanena] gṛyante, ra ity eva tasya siddham, MB , Vol. I, Sec. I, p. 84 .

51. lādeśe ca rikāra -grahanam kartavyam/ krpo ro lah/ rkārasya ceti vaktavyam/ ihāpi yathā syăt/ klptptah̆, klptavān iti MB, Vol. I, Sec. I p. 84 .

52. athavobhayatah sphota-mātram nirdiśyate/ ra-śruter la-śrutir bhavati, $\overline{\mathrm{MB}}, \overline{\mathrm{Vol} . \mathrm{I}}, \overline{\mathrm{Sec} . \mathrm{I}, \mathrm{p} .} 8 \overline{4}$.

53. athavā sphota -mātram ity ākrti -nirdeśo' yam ity uktam bhavati ... ākrty-āśsayanasyedam prayojanam, antarbhūtānantar -bhütayo rephayoh pratipatty -artham, $\underline{\mathrm{MB}}-\underline{\mathrm{D}}$, p. 76 .

54. sphotạ-mātram iti jāti -sphota ity arthah/ tataś cāntarbhūtänantarbhūta -repha-lakāra-vyakti -vyañgyam sāmānyam sthāny -ādeśa -bhāvenāśríyate/ MB-P, Vol. I, Sec. I. p. 84. Kaiyata's argument is upheld by the commentary Nārāyaniyam: anugata -buddhi -vedyatvāj jāteh, antargatatve api 'ra' ity-ādi-rūpa-sad-bhāvāj jāty -abhyupagamah $\ldots$ '. 'ra' ity āà -anubhava -mātrena jātim vastu-satīm asatīm vā svikrtya śabdānusâsanapravr tter nāyam artho yuktya bādhanīyah̆/, Nārāyaṇiyam, MPV, p. 171 .

55. On this passage, John Brough says: "This can be approximately rendered in modern terminology, 'In both the cases the phoneme is meant, i.e. "an allophone of the $/ \mathrm{r} /$-phoneme is replaced by an allophone of the /l/-phoneme." It is of interest to observe that Patañjali realized that for the phonology of Sanskrit it is convenient to $\mathrm{regard} / \mathrm{r} /$ and $/ \mathrm{r} /$ as belonging to the same phoneme." Brough (1951), p. 37. Perhaps, Brough is reading too much into Patañjali's statement. Patañjali does not even consider $/ \mathrm{r} /$ and $/ \mathrm{r} /$ to be homogeneous (savarna) [ rephoṣmanāin savarnã na santi, MB, Vol. I, Sec. I, p. 88] The consonantal $/ \mathrm{r} / \mathrm{is}$ considered to be 
Isat-sprsta "with slight contact," while / $\mathrm{r} /$ is vivrta "open." "Thus, they are not homogeneous with each other. The relationship is rather like part and whole. The phonemic identity is not between $/ \mathbf{r} /$ and $/ \mathrm{r} /$, but rather between $/ \mathbf{r} /$ occurring independently, and $/ \mathbf{r} /$ as a part of $/ \mathbf{r} /$. This has been clarified by S. D. Joshi (1967), p. 16. Thus, $/ \mathbf{r} /$ and $/ \mathrm{r} /$ do not belong to the same sphota, but $/ \mathrm{r} /$ inside and outside belongs to the same sphota. Whitney thought that $/ \mathrm{r} /$ and $/ 1 /$ were originally phonetically the same with $/ \mathrm{r} /$ and $/ \mathrm{l} /$. Whitney on TPr, p. 59. He also says: "Some consonants are capable of use as vowels. The consonants most often employed with vocalic quality are $/ 1 /, / n /$ and $/ \mathrm{r} /$. A higher grade of vocalic capacity belongs to $/ \mathrm{r} /$ and $/ \mathrm{l} /$ than to any other of the sounds reckoned as consonantal, in virtue of the more open position assumed by the mouth organs in their utterance, which gives them a share in the sonorousness and continuability characteristic of the vowels." Whitney (1884), pp. 362-3. In contrast to Whitney's conception, Indian phoneticians considered $/ \mathrm{r} /$ and $/ 1 /$ to be rather composite sounds, with vocalic and consonantal parts.

56. yat tu svatantrāsvatantra -sādhārana -jāti -paratayā etadbhāsya -vyākhyānam iti tan na/ tādriśa -jātau mānābhāvāt, MB-P-U, Vol. I, Sec. I, p. 85. This explanation of Nāgeśa agrees with that of the commentary Ratnaprakăsa on the MB. This commentary says that the Bhāsya does not indicate the existence of a universal (jäti) common to $/ \mathbf{r} /$ inside and $/ \mathbf{r} /$ outside. The Bhäsya refers only to the sound (dhvani -mattra) which is common to $/ \mathrm{r} / \mathrm{which}$ is the locus of $/ \mathbf{r} / \overline{\text {-ness, }}$ i.e. independent $/ \mathrm{r} /$, and the $/ \mathbf{r} /$ sound in $/ \mathrm{r} /$. [MPV, pp. 169-170.]

57. Cardona (1969), p. 7. Also: rti * ${ }^{*}$ vā, liti * ubhayatrāpi vidheyam varna-dvayain dvi-mătram, addyasya madhye dvau rephau tayor ekā mātrāa, abhito'jbhakter aparā/ dvitīyasya tu madhye dvau la -kārau, sesam prāgvat, SK, p. 7.

58. yathākāro' -ṇtvād dīrgha -plutāv api gṛhṇāti, evam bhaktim api grahisyati iti ākrti-grahane va sarvatrākrter bhāvāt, $\underline{\mathrm{MB}}-\underline{\mathrm{D}}, \mathrm{p} .76$. 
59. idam varna -turīyam anyatrādrșțam kvacit, sāvarnyam api nāsti / na hy atra samudāya -prayatnād anyo'vayavaprayatno nāpi sthānam/ na tv esa varna -bhāgah saknoti jātim upavyañjayitum $\overline{\mathrm{MB}}-\mathrm{D}, \frac{\mathrm{pp}}{\mathrm{j}} \cdot \mathbf{7 6 - 7}$.

60. tasya bhāgasya sphuta-pratibhāsāvisayatvāt jātyabhivyakti -hetutvābhāvāe ceti bhāvah, MB-p, Vol. I, Sec. I, p. 85 .

61. atvādi -jātīty arthah/ evam ca na kenāpy acā tad-grahanam iti bhāvah/ a tra jāty -abhivyakti -hetutvābhāve sphutapratibhāsāvișayatvam hetuh/ $\mathrm{MB}-\underline{\mathrm{P}}-\underline{\mathrm{U}}$, Vol. I, Sec. I, p. 85 .

62. edaitor odautoś ca na mithas sāvarnyam/ ai -au-c iti sütrāra mbha-sāmarthyāt/SK, p. 3.

63. ṛkāralkāroyoh savarna -vidhịh ity asya vārttikakāra vākyatvāt sūtrakārenānāśrita tvād atra lkāropadeśă krtah/MB-P, Vol. I, Sec. I, p. 72. Aiso: vastutah sūtra-mate llkārasya rkārena sāvarnyābhãvena grahanābhā vāt, Jyotsnā on $\overline{L S} \bar{S}$, p. 127. Thieme realizes the unhistoricity of Kātyāyana's statement and calls it "ein Postulat." Thieme (1935b), p. 171.

64. asya hi lkārasyālpiyāmós caiva hi prayoga-vișayah/ yaś

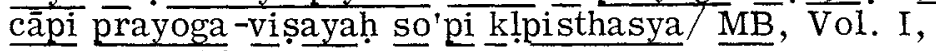
Sec. I, p. 72 .

65. Cardona (1965b), pp. 310-1.

66. Thieme (1935a), p. 112.

67. rkāra-lkārayoh savarna-vidhih, Vt, MB, Vol. I, Sec. I, p. 158 .

68. Deshpande (1972), p. 230. On this vārttika, Devasthali comments: "This is a vārttika composed by Kātyāyạna, who coming about two centuries after Pānini sought to remove the deficiencies in $\mathrm{P}^{\prime} \mathrm{s}$ rules. It is not impossible that some deficiencies might have crept into the Asțādhyāyi in spite of $\mathrm{P}$; but what is also [and even more] likely is that the language which formed the basis of his rules, being a living language, underwent several modifications, thus making $\mathrm{P}^{\prime} \mathrm{s}$ rules deficient in course of time." Devasthali (1969), p. 7. The general thesis of language 
change being the basis of Kātyāyana's vārttikas is advocated by Devasthali elsewhere ["The Aim of the Vārttikas of Kātyāyana," Munshi Felicitation Volume, Bharatiya Vidya Bhavan, Bombay, 1962]. Whatever its independent merits, this thesis cannot be really applied to Kātyāyana's proposed homogeneity of $/ \mathbf{r} /$ and $/ 1 /$. The reason is not historical linguistic change. Devasthali himself says that $/ \mathrm{r} /$ and $/ 1 /$ are said to be homogeneous despite the fact that they have different points of articulations [Devasthali (1969), p. 7] . The only reason Kătyāyana needed this homogeneity is the change in linguistic attitude. Pānini looked at the use of $/ /$ only in the object language, i.e. only in the forms of $\widehat{k ! ̣ p}$, while Kātyāyana also tried to take care of grammatical expressions with $/ 1 /$, and imitation expressions etc. [For details, see: above, Sec. 3.12-13.] Siddheshwar Varma $(1929$, p. 7) believes that there was actually a real linguistic change, i.e. / r/ and $/ 1 /$ came to be pronounced at the same point of articulation and hence their homogeneity was inevitable. He claims that the later Pāniniyas did not realize the contradiction in giving different points of articulation for $/ \mathrm{r} /$ and $/ ! /$, and also saying that they are homogeneous. Though certain traditions recorded in the Prātisāalkhyas and Sikșās did accept / $\mathbf{r} /$ and $/ 1 /$ to have the same point of articulation, there is no proof that this was universal and was accepted in the Pāninian tradition. Thieme has discussed and refuted Varma's views, Thieme (1935a), P. 108. Interestingly, we find a totally different view in Viśveśvarasūri's VSSN, p. 90. Viśveśvarasūri refers to the view of the $\mathrm{RPr}$ that $/ \mathrm{r} /$ and / $/$ are both jihvā -mūliyas "produced at the root of the tongue," and says that this naturally leads to their homogeneity. He refers [Ibid, pp. 90-1] to an important indication in Pānini's rule: ród-upadhāc cāklpi -crẹteh P.3.1.110. This rule refers to roots with $/ \mathrm{r} / \mathrm{as}$ their pre-final sound, except klp and cr.t. This could be interpreted to suggest that Paninini did accept homogeneity of $/ \underline{r} /$ and $/ 1 /$. However, it may also be argued the klp is the normal way of referring to the meta-root krp, and hence the rule need not imply homogeneity of $/ \mathrm{r} /$ and $/ 1 /$. 
69. yadi tarhi rkāra-grahane 1kāra-grahanam sannihitam bhavati, ur an ra -parah h jkārasyāpi raparatvam prāpnoti, MB, Vol. I, Sec. I, p. 159.

70. lkārasya laparatvam vaksyāmi/ tac cāvaśyam vaktavyam/ a satyām savarna-samjñ̄āām vidhy -artham/ tad eva

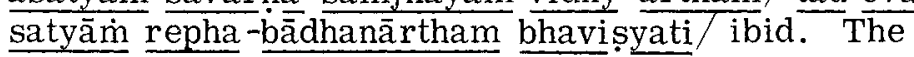
statement of Patañjali, namely "T shall prescribe (vaksyāmi) [ the substitute vowel] for $/ 1 /$ to be followed by i " is actually a totally new provision, which is not found in Pānini's rules. However, Bhartrhari takes vakșyāmi to be the same as vyākhyāsyāmi..'I shall [re-]interpret." Then Bhartrhari introduces the notion of the shortform $/ \mathrm{rA} /$, formulated by declaring the $/ \mathrm{a} /$ in lân to be nasalized and hence being an it "marker." Thus, from $/ r /$ in hayavaraT to $/ A /$ in $1 \bar{A} N$, we get $/ r /$ and $/ 1 /$ in the shortform $/ \mathrm{rA} \%$. [ l kārasya laparatvam vakșyāmi vyākhyāsyāmīty arthah rat lan iti lakāre yo' kärah a sau anunāsikah pratijñãsyate atah svenānyenetaraḥ it iti rephah ādih tan-madhyasya samjn̄ā bhavisyati/ur an raparah iti rephas tan-madhyam lakāram pratyāyayati/ evam api ubhayoh ra-lau kasmān na bhavatah/ MB-D, p. 149.] This interpretation is followed by the later tradition up to Bhattoji Dikșita. Nāgeśa, however, criticizes this shortform, for being unhistorical. He points out that Pānini independently uses $/ \mathrm{r} /$ and $/ 1 /$ in rules like P.7.2.2 (ato lrāntasya). He also notes that if $/ a /$ in laN were a meta-element, Pānini would have used the shortform $/ y$ A / for yaN [LSS, pp. 24-6] . A. M. Ghatage has missed the point in his explanation: "A nasalized form (of $/ \mathrm{a} /$ ) is used by $\mathrm{P}$ as an it in Siva-sūtra 6 , taking advantage of the fact that Skt. uses no nasal vowels as distinctive." Ghatage (1972), p. 158. For the right historical view, see: K. M. K. Sharma (1968), p. 29. Also: Thieme (1935b), p. 200.

71. yadā ca r rkāra-lkārayoh savarna -vidhir ākrti -grahanāc ca grahanaka-śāstram pratyākhyāyate tadā saty api śrutibhede ekāk rtitvam eva yathā hrasva -dīrghayor iti MB-D, p. 64 . 
72. vārttika -mate savarne'n-grahanam aparibhāșyam ākrti-grahanād iti sidd̄hāntād ruāre ḷkāra -sādhāranajāti -virahenāke ți-grahanāsambhavāt SKB , p. 39.

73. tasmād an-grahanam pratyācakșānasya tat-sthāne rgrahanam karttavyam/SKB, p. 40 .

74. ārabdhe'pi vārttike rkāra -lkārayoh sāvarnya syānityatām jñāpayitum karttavya eva 1 kāropadeşah/ tena kT̄3ptasikha ity atra guror anrta iti plutah siddhyati 7 anyatha anrta iti niședhah syāt $;$ ṛārena lkāra-grahanăt/ SKB, p. $\overline{39}$.

75. r - l-varnayoh sāvarnyam ity anena samāna -jātitvasya evātideśena...na dosah LSS, p. 129. Also: sāvarnyavacanena samāna -jāty-atideśam eva vakșyati, Cidasthimālā on $\underline{\mathrm{LSS}}$, p. 127.

76. samāno varno jātir ity arthah/varnāśramācāravān ity ādau varna-padena jāter vyavahārät iti bhāvah, Sadâsivabhatțiya on LSS, p. 129.

77. lakāra-rephayoś ca samāna -śrutitā kavi-sampradāye prasiddheti r.tva -jātir lkāre py asty eveti tatrāpi na doșah/ BSS, Vol. I, p. $\overline{66}$.

78. a-i -u-n iti eșu jāti-paro nirdeśah/ ... tatra yady api hrasva -dírgha-pluta-sādhārañi jātir asti tathāpi ta syā atra na nirdesah/an -udit-sūtre an-grahanāt/ kin tu tadvyāpyā hrasva-mātra -vrttir api sā svikriyate, vyavahāra balāt/ tasyā atra nirdeśah/ (ata evāsya cvau ity ādau anudit-sütra-pravrttih)/ ata eva 'dírghānām anantvena savarnāgrāhakatvam' iti siddhāntah sangacchate caivam api dírghādīnām actvam na syāt isțāpatteh an anudit-sūtra-pravrttyā, lakșanayā vājādi-padais tadupasthitih sāstre ity agre nirūpayisyāmaḥ/... yad vā vyāpaka-jâti -nirdeśa evātra/ an-udit-sūtra-prayojanam tu vaksyate BSS, Vol. I, pp. $2-3$; also SKB, p. 37 .

79. Actually, $/ \mathrm{a} /$ and $/ \mathrm{h} /$ do not have the same internal effort, according to the Panninian tradition. The short /a/ is samvrta "closed," while $/ \mathrm{h} /$ is vivrta "open." In order to have homogeneity of closed /a/ with open $/ \bar{a} /$, Pānini considers /a/also to be open, within the system. The final rule of his system, P.8.4.68 (ㅁa), reinstates 
closed /a/for open /a/ in the object language. There were other traditions, which considered short /a/ to be open even in the object language. For instance: Rktantravyākarana (3.8) says: vivṛta -taram akāraikāraukārañām. The same view is adopted by Abhayanandin in his Jainendra-mahāvrtti [see: Sec. 12.4.1] and by Hemacandra in his B rhad-vrtti [see: Sec. 12.7.3]. For views of the Prātis̄ākhyas, see. n. 261. Also Rāmajñā Pāndeya $(196 \overline{5})$, p. 160 , says that the Gaudas pronounce open short $/ \mathrm{a} /$. K. C. Chattopadhyaya (1974) argues that Pānini himself considered/a/ as an open sound. The later Pāninīyas, however, had a closed short $/ a /$ under the influence of ancient Dravidian and they designed the final rule of the Asțādhyāyí, P. 8.4.68 (a a), to explain away the problem. I have dealt with Chattopadhyaya's argument in my article "Phonetics of Short /a/ in Sanskrit," which is due to appear in the Indo-Iranian Journal.

80. jāti -pakșe doșa eva na, itva -ŝatvādi -jāter bhedāt, Cidasthimā $\overline{l a}$ on LSS, P. 122, and also Sadāśivabhattiyam on LSS, p. 122. Bhattoji is also aware of this implication: vārttika -mate tu hakārākārayor ekajäty -anākrāntatvād eva nātiprasañgah, SKB, p. $12 \overline{3}$.

81. V. N. Misra (1966), p. 105, gives a very confusing account of this rule. This view is discussed in Sec. 5.9.

82. udid-grahanami karttavyam eva/ nahi vargyānām ekākrtiyogo sti, MB-P, Vol. I, Sec. I, p. 375. Also the commentaries on LSS, p. 129 and 130.

83. atredam bodhyam/ vyaktịh padārtho gunāh bhedakāh ity

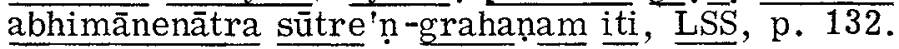

84. upātto'pi viśseșah nāntarīyakatvāj jāti -prādhānyavivakșāyām na vivaksyata ity arthah/ MPB, Vol. I, Sec. I, p. 60 .

85. atra (jāti) pakse a -i -u -n - sūtra -ŝesokta-bhāșya -rityā tapara -sūtrasya jāti -grahana -prāpta -savarna -grahananiyāmakatvavad apratyaya ity asya yoga -vibhāgena tatprāpta-savarna-grahana -nisedhakatvāt tyadādinām ặ ity âdau vidheye na doșah $/ \overline{L S S}$, pp. 129-30. Also: jāti- 
pakșe'py anayaiva paribhāsayā savarna-grahanami vāraniyam, LSS, p. 125.

86. For various interpretations of P.1.1.70, see: Sec. 8.5-6. Also: Deshpande (1972), pp. 213, 249-51.

87. tadvac ca tapara-karanam, Vt on the Siva-sütra $1, \mathrm{MB}$,

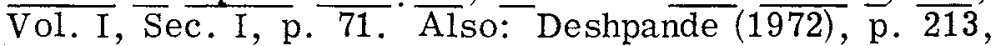
fn. 19 , and p. 231.

88. evam ca krtvā taparāh kriyante/ ākrti-grahanenātiprasaktam iti krtvā/ $\mathrm{M} \overline{\mathrm{B}}, \mathrm{Vol}, \mathrm{I}, \overline{\mathrm{Se}} \mathrm{c} . \mathrm{I}, \mathrm{p} .71$.

89. tulya -nyāyāj jāti -grahana-prayuktātipra sañga -nivāranāya taparatvavat vidheye tyā̄ādinām ah ity ādau ta d-vāranāya apratyaya iti $\frac{\text { etad iti }}{\text { bodhitam, }} \overline{\mathrm{MB}} \dot{\mathrm{B}}-\underline{\mathrm{P}}-\overline{\mathrm{U}}, \mathrm{V}$ ol. I, Sec. I, p. 71 , and $\bar{p} \cdot 376$.

90. Deshpande (1972), p. 211, Fn. 15; and Cardona (1965a) p. 227.

91. See: Sec. 8.5-6.

92. asțana ā vibhaktāv ity atra yatnādhikyãd dīrgha -vyakti samavetam sāmānyam grhyate, MB-P, Voí. I, Sec. I, p. 374. Also: atra tu ầāra -grahane jāti -nirdeśād akāra-grahanam prāpnoti/ tat tu na prāpnoti, prayatnabhedầt yathà pūrva-vayā brāhmañạ pratyuttheyah/ plutasya tu prāpnoti taträpi parihärah/plutaś ca visaye smrttah iti/ MB-D, p. 57.

93. kecit tu dirgha-sad-bheda -vrtty-ātva -jāter eva atvavyāpyāyās tatra nirdeśa iti vadanti/ MB-P $-\bar{U}, \overline{V o l}$. I, Sec. I, p. 374 .

94. Deshpande (1972), pp. 210-5, 238-42.

95. ibid, p. 239.

96. i ceti hrasvah supathah, SK, p. 272.

97. See: n. 94.

98. SK, p. 2. Traditionally, the term ūsman is applied to $\overline{\mathrm{s}} /, \mathrm{s} / \mathrm{s} / \mathrm{s} /$ and $/ \mathrm{h} /$, in the Pāninian tradition. Sometimes Patañjali uses this term with reference to aspirate stops, but in the present context, the term stands only for $/ \mathrm{s} /, / \mathrm{s} /, / \mathrm{s} /$ and $/ \mathrm{h} /$ [ yady api varga-dvitíya- 
caturthayor api sthāne'ntaratama -sūtra -bhāsyād ūṣmatvam, tathāpi 'vivrtam ūsmanām' ity atraita eva grhyante LSS,

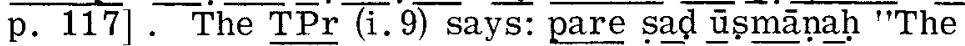
latter six sounds are üșmans, "and Whitney comments on this as follows: "Namely, the three sibilants, $/ \dot{\mathrm{s}} / \mathrm{,} / \mathrm{s} /$, and $/ \mathrm{s} /$, the jihvāmūlĩya, $x$, the upadhmāniya, $\phi$, and the aspiration, $/ \mathrm{h} /$. As regards the sounds to which the name üsman 'flatus,' shall be given, the phonetic treatises are at great variance. The Vāj. Pr. (viii.22) limits the class to sibilants and $/ \mathrm{h} /$; the Ath. Pr. (see note to i.31) apparently adds the guttural and labial spirants and the more indistinct visarjaniya; the Rik $\mathrm{Pr}$. (i.2), those and the anusvāra." Whitney on the $\overline{\mathrm{TPr}}, \overline{\mathrm{p}} .14$.

99. vivrtam svarosmanām, Rktantra -vyākarana 3.7 ; tatrābhyantarah (21), samivrtatvam viv rutatvam sprstatvam issat-sprsțatvam ca (22), Cāndra-varna-sūtras, Śikșāsūtrāni, p. 25; (ūṣmanām) karana -madhyam tu vivrrtam, TPr (ii. 45); svarā̄nusvārosmanām asprștam sthitam, RPr,

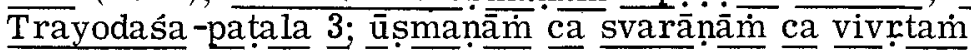
karanam smrtam, verse 29 , Die Pāniniya-siksā, p. 355;

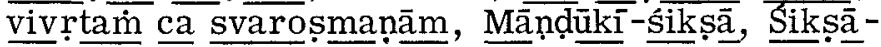
samgraha, p. 469.

100. śașa sahānām yathā kramam ikāra -rkāra -lkārākārāḥ sūtra-mate yady api tulyāsya -prayatnās tathāpi na

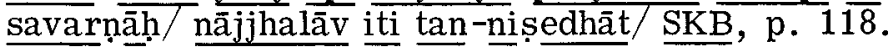

101. atra hi sūtre 'ac' iti ikāro grhyamānah savarnam gṛnnāti iti śak̄ārasyāpi grahanam asti/ svātmani kriyā -virodhā asminn eva sūtre idam eva na vyāpriyata iti savarnatvaniședha ikāra -śakārayo hā sti ... asti ca pūrvena savarnatvam ikāra-śakarayor iti bhāvah $\overline{\text { MB-P }}, \bar{V}$ ol. I, Sec. I, p. 160; also LSS, p. 122 .

102. This problem does not arise with other vowels like $/ i /$ or $/ \mathrm{u} /$. The sound $/ \mathrm{a} /$ is an $/ \mathrm{a}-\mathrm{N} /$ sound and represents its homogeneous sounds. The sounds $/ \mathrm{s} /, / \mathrm{s} /$ and $/ \mathrm{s} /$ could be perhaps represented by $/ \mathbf{i} /, / \mathbf{r} /$ and $/ 1 /$, but cannot represent them, since they are not $/ \mathrm{a}-\mathrm{N} / \mathrm{s} /$ sounds. Bhattoji mentions various problems which this would create. He says: tathā ca pürva-pakșa-vārttikamajjhaloh pratiședhe śakāra-pratis sedho'jjhaltvāt iti/ atra sakāra -grahanạm śarām upalakșanam kiñ ca avarnasyā- 
șţădaśadhā bhinnasya parasparam sãvarnyam na syāt/ tataś ca 'dandāgram' ity ādau dírgho na syāt/ tathā hi

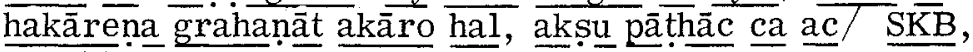
p. 121 .

103. ajjhaloh pratisedhe sakāra-pratisedho'jjhaltvāt, Vt. on P.1.1.10, MB, Vol. I, Sec. I, p. 160 .

104. ac caiva hi sakāro hal ca/ katham tāvad actvam/ ikärah savarna-grahanena śakāram api grhnātīty evam actvam/ halșu copades̃ăd dhaltvam/ BM, Vol. I, sec. I, p. 160.

105. tatra savarṇa-lope dosah, Vt. on P.1.1.10, paraśśatāni karyāni/jharo jhari savarne iti lopo na prāpnoti/MB, Vol. I, Sec. I, p. 160 .

106. siddham anactvät, Vt. on P.1.1.10, MB, Vol. I, Sec. I, p. 160 .

107. Apparently, Patañjali himself is not quite sure of the interpretation of this vārttika. He gives another

alternative explanation of the sequence: siddham anactvāt, vākyāparisamāpter vā. In this second interpretation, he says: siddham etat/katham/ anctvāt/ katham anactvam/ vākyāparisamāpter vā/MB, vol. I, Sec. I, p. 162. In this interpretation, both the vârttikas together form one solution, but as Patañjali himself notes, the word vă "or" becomes purposeless [asmin pakse vā ity etad asamarthitam bhavati, $\underline{\text { MB }, ~ V o l . ~ I, ~ S e c . ~ I, ~ p . ~ 162] . ~}$

108. siddham etat/ katham/ anactvāt/ katham anactvam/ 'sprstam sparsanām karanam'/ 'ișat-sprestam antah -

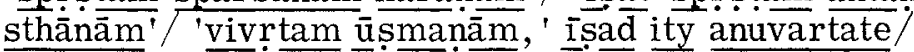
'Svarānām ca' vivrtam, is sad iti nivr.ttam/MB, Vol. I, Sec. I, p. 160 .

109. sūtra -pratyākhyāna -sādhāranam uktam/ prayatna-bhedād ajjhaloh savarna-samjñ̄āāh prāptir eva nāstíty arthah/ MB-P, Vol. I, Sec. I, p. 161 .

110. vastutas tūkta -rītyā (prayatna-bhedena) sūtram eva nārambhaniyam ity arthah/ SKB, p. 121.

111. "AP 1.31 reads ūsmanām vivrtam ca, in which ca refers to Isat of 1.30 , hence the spirants are classed as isadvivrta. " Cardona (1965a), p. 226. This interpretation 
of the APr 1.31 clearly follows Patañjali. This, however, may not necessarily be the meaning of the original rule. See: Sec. 4.7.

112. bhāşyakārās tu 'nājjhalau' ity asya pratyākhyānāvasare

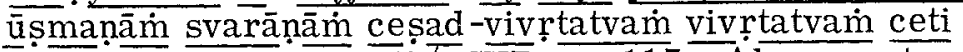
vailakșanyam vaksyantiT SKB, p. 117. Also: saptaprayatnā iti bhāsya-rityā..., Sadāsivabhatțiya on LSS, p. 92. bhāsyakāra-mate tu prayatna-bheda eveti vaksyate/ SKB, p. 118 .

113. bhāsya -mate tu santu sapta -prayatnāh, LS9, p. 103.

114. svarāṇām ūṣmañām caiva vivrtam karanam smrtam/ tebhyo'pi vivrtāv eñau tābhyām aicau tathaiva ca/iti śikșā-vākyāt viv rutatara-vivrtatamayoh pratītyā nājjhalāv iti sūtra-bhāsyād üsmanām isad-vivrtatvasya ca pratityā..., LSS, p. 103. The verse quoted by Nãgeśa is No. 29 in the Yajus Recension of the Pāniniya -śikșā [See: Die Pānininiya-śikșā, p. 355] .

115. tathā ca sikșā-vivrta-karanāh svarāh, tebhya e o vivrtatarau, tābhyām ai au, tābhyām apy ākārăh, samvrto'kārah/, KS-P and KS-N, Vol. I, p. 22. Also: Sikșā-sútrāni, pp. 3-4, 12, 25 .

116. avarnasya tarhi aicoś ca savarna -samjnāa prāpnoti/ [na], vivrtatarāvarnā̄ vetau $\mathrm{MB}$, Vol. $\overline{\mathrm{I}}$, Sec. I, p. 155; also: santu sapta-prayatnāḥ/ māstu ca nājjhalāv iti sütram/ata eva tulyāsye ti sūtre bhāsye avarna syaicäm ca sāvarnyam à śankya vivrtataratvenaiva parihrtam/ BSS, Vol. I, p. 48.

117. tadā (bhāsya -mate) santu sapta -prayatnāh / evam ca edaitor odautoś ca na sāvarnya-prasaktị prayatnabhedād ity alam $\widehat{B S S}, \overline{p .} 48$. Also: $\mathrm{MB}-\underline{\mathrm{P}}-\mathrm{U}, \mathrm{Vol}$. I, Sec. I, p. 161 .

118. Șașasahānām yathā-kramam ikāra -rkāra -lkārākārāh sūtrakāra -mate tulyāsya-prayatnăh $h$ SKB, p. 118.

119. na ca 'nājjhalāv' iti nirdeśena bhãsyokta -prayatnabhedasya sūtrakāābhipretatva ma kalpyate iti vācyam/ BSR, p. 12 . 
120. nājjhalāv iti sūtreṇa vivr tatva -vyāpyānām esāàm savarna samjñanupayuktatva -bodhanam ity āśayāt, LSS, p. $10 \overline{3}$. The commentary Visamapadavivrti on LSS (p. 102) believes that P.1.1. 10 is necessary even after accepting Patañjali's proposal of prayatna-bheda. It points out that the special variety $/ * 1 /$ is ísat-sprsța "with slight contact" like the consonant $/ 1$, and both have the same point of articulation, i.e. danta "teeth." For this reason, they would be mutually homogeneous. To avoid this, we have to take recourse to P.1.1.10. That $/ * 1 /$ is issat-sprsța is quite clear. It is also clear that this special variety $/ * 1 /$ is not homogeneous with $/ 1 /$ which is vivrta "open." See: ". . die beiden Laute $[/ * \dot{r} /$ und $/ * 1 /]$ nicht 'ac' heissen, wenn sie nicht ausdrücklich durch Hinzufügung einer Angabe so genannt werden. Sie sind also weder in den SS. [S Siva-sūtra] aufgeführt, noch den dort aufgeführten Lauten $/ \mathbf{r} /$ und $/ 1 /$ 'gleichlautig." Thieme (1935b), p. 181. The view expressed by Visamapadavivrti involves some element of anachronism. The sounds $/{ }^{*} \mathbf{r}$. and $/ * 1 /$ are not mentioned by Pānini, but are introduced by Kātyāyana in his vārttikas r.ti *r. vā and lıti ${ }^{*} !$ vā on P.6.1.101 (akah savarne dírghạh). It is quite possible that these sounds themselves are of a later date in Sanskrit usage. Again the commentatore are not sure if these sounds are vocalic. We could say that $/ * 1 /$ [i.e. əllə] is less vocalic than $/ 1 /[$ i.e. ələ] and is more vocalic than $/ 1 /$.

121. bhāsya-mate tu santu sapta-prayatnāh/ evam caidaitoś ca na sâvarnya-prasaktih, prayatna-bhedād iti bodhyam/

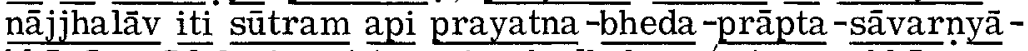
bhāvānuvādakam sat tasyaiva bodhakam ata eva bhāșye tan na vaktavyam iti noktam/ LSS, p. 103. Also: atra pakș nirāca ște/ Cida sthimālā on LSS, p. 103. Madhukar Phatak (1972, pp. 146-7) says that even Pannini knew the subdivisions of vivrta into ișad-vivrta etc., but he did not accept them in the context of the notion of homogeneity. Jagadīśa Citrācārya [Şikșā-sāstram, p. 12] ascribes a fivefold division of internal efforts to Pānini including issad-vivrta. These suggestions are groundless. 
122. yadi tu sütra-vrttyādisu śraddhā-jādyam apahāya prayatna -bhedād evaitad -vyāvarttya -sāvarnyānāin na sāvarnyam ity ucyate, tadā santu sapta-prayatnāh̆, māstu ca năjjhalāv iti sūtram/ BSS. Vol. I, p. 48.

123. Kielhorn (1876b), p. 193.

124. Śikșā-sūtrāni, pp. 3-4. Limaye (1974, pp. 57-8) refers to this passage in the Apisali-śiksāa and says that Patañjali probably quotes from this Sikșa. In support of his view, he quotes a passage from Vrsabhadeva's commentary on the Vakkya-padiya which ascribes the above passage in Patañjali to a Sikșākāra. B. A. van Nooten $(1973$, p. 409) thinks that Patañjali quotes from the Apiśaliśikșă, rather than the Sikșā quoting Patañjali. However, I think that the Apisalissiksa in its present form is post-Patañjali. If he knew this text as we know it, he would have directly quoted this Sikșā to show that spirants are isad-vivrta "slightly open," instead of quoting the $S \overline{C A}$ and reinterpreting it. For more details on the chronology of the Apisalisikșā, see my article now in preparation for the Journal of the Oriental Institute, Baroda, "The Date of the Apiśali-siksā sūtras."

125. Thieme (1935a), p. 87, Fn. 2.

126. APr, p. 360 . Also see: n. 111.

127. Die Pāninìya Sikșā, pp. 355-6.

128. Ibid, p. 355 .

129. îsad-vivrta -karanā sūtrāni, p. 12 .

130. İsad-vivrta-karanā ū

131. R. Pandeya (1965), p. 202.

132. $\underline{\operatorname{Pr}}(\underline{\mathrm{W}})$, pp. 118-9: ardha -spr șțatā sya -prayatnā ū üsmāno' nusvāraś ca.

133. ūṣmāno' rdha -sprósah/ Yājnavalkya -śiksāa Sikșā-samgraha, p. $\overline{32}$.

134. ardha -sprșțāŝ ca vijneyā ūsmāno varna -vedibhih/,

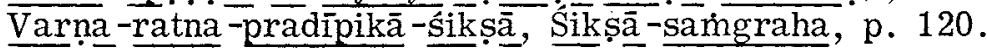


135. S. C. Vasu (1891), Vol. I, pp. 62-3.

136. Ibid.

137. Ibid., p. 13.

138. See: Sec. 7.2.2.

139. S. D. Joshi (1969), p. 23. His footnote 127 on p. 23 says: "The principle of grahana means that all vowels included in the pratyāhāra /aṆ/ stand for themselves and their corresponding homo-organic varieties also." This needs to be enlarged, since semi-vowels also represent their homogeneous varieties by P.1.1.69. Similarly, P.1.1.69 also says that sounds marked with $/ \mathrm{U} /$ stand for their homogeneous sounds.

140. Ibid., fn. 128.

141. Ibid., fn. 130. On the maxim grahanān-grahane grahanābhāvah, which is quoted by Kaiyata, S. D. Joshi says:

"The quotation is probably from the lost part of Bhartṛhari's Mahābhāșya-dipikā." It is actually found in MB-D, p. 174 (Swaminathan's edn.). Also see n. 161.

142. evam̉ ca hal iti sūtre lakārasya it-samijñāyām satyām 'ãdir antyena sahetã ' iti hal-samjñ iti sūtra -pravrttih; 'hal antyam' iti sütrena hal-sūtre lakārasya it-sam̄jñāyām 'ādir antyena sahetā' iti halsamjñā-siddhih/ ity evam 'hal antyam, ' 'âdir antyena' ity anayoh paraspara -sāpeksat vena anyonyāśrayatvād abodhaḥ/ Bālamanoramā on SK (M) , Vol. I, p. 5.

143. eka-s̉eșa-nirdeśād vā, Vārttika 5 on P.1.1.3, MB, Vol. I, Sec. II, p. 130 .

144. hal ca hal ca hal, hal-antyam it samjñam bhavati/MB, Vol. I, Sec. II, p. 130 .

145. hasya 1 hal/ hal ity ekah sasthi-tatpuruṣah/ dvitiyah pratyāhārah $\overline{M B}-\underline{P}$, Vol. $\bar{I}, \overline{\text { Sec. II, p. }} \overline{1} 30$.

146. tasmãd vākya-dvayam apy anta-pada-ghațitam/dvandvānte śrūyamănasyaiva pratyekam sambandhāt tayos ca tantrenoccāranam bhāsye iti hal-sūtrāntyam antyam ca hal it ity eva bhāsyārthah ekaśesa-sabdena ca bhāsye tantram laksyate $\mathrm{MB}-\underline{\underline{P}}-\underline{\mathrm{U}}$, Vol. $\overline{\mathrm{I}}$, Sec. I, p. 130 . 
147. hal antyam/ hal iti sūtre'ntyam it syāt/ ādir antyena sahetā/ antyenetā sahita âdir madhyagānām svasya ca

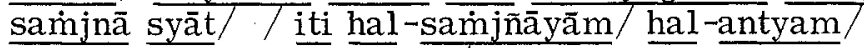
upadeśe'ntyam hal it syât/, SK, p. 1.

148. yathā ac ca gheh ity âadau guna-darśanena ghi-śabdasyāpi ghi-sa

149. nanv evam 'tulyãsya -prayatnam savarnạm, ' 'nājjhalāv' ity adāv 'akah savarne dírghah' iti dírgho' pi na pravartteteti cet, na, savarna -samjñ̄ādy -uttara -kāle pravarttamānasya dîrgha -śāistrasya danḍa dụhakādāv iva ihāpy apratibaddha -pravr ttikatvāt, uddésyatāvacchedakarūpākrāntatvāviśeșāt/ ... anyathā vyākarana -sāstrapariśīana-vikalānāì kvāpi śābda -bodho na syät/ tathā vaiyākaraṇānām api vyākaraña-sūtra-ghataka-sabdeșu vyākaranā d eva sādhutva-bodhe tad -uttara -kāle ca vākyārthāvagatau ātmās̄rayānyonyāŝ́raya-cakrakānāàm durvāratvāt iti dik SKB, p. 122.

150. yat tu varnopadeśa -kāle'jādi-samjñānām aniṣpādāt sandhir neti/tan na varnopadeśa it-samjiñāyām acpratyāhāre ca jñāte, 'upendra' ity âa dau tațastha ivoddeśyatāvacchedakāvacchinne varnopadeśāāāv api pravrtter äpādayitum śakyatvāt vākyāparisamāptinyāyasya tu nāyam vissayah/vākyārthāpratibandhakatvāt/ ... ata eva ' 'sarūpānām,' 'nājjhalāv' ity ādāv ekaśeșadīrghādi siddhyati / spastā ceyarn rîtir 'bhute iti sūtre

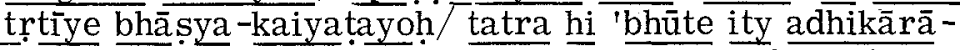
śrayā nistthā, bhūta -kriyā-vișaya -nisthāa -vidhānāśrayo bhūtādhikāra' ity anyonyāśrayam àśankya, 'bhūta-śabdo hi nityah, śāstram cānvākhyāna -mātram' ity āśritya samāhitam/ BSS, Vol. I, pp. 3-4. Patañjali discusses this question in detail. The affixes $\mathrm{Kta}$ and $\mathrm{KtavatU}$, called nisthāa, are prescribed under the section bhüte "to signify past tense" [P.3.2.84]. Now the word bhüta itself is derived by applying the affix Kta to the root bhü. This involves an apparent interdependence. Unless we derive the word bhüta, there cannot be a prescription of the affix Kta, and unless this affix is prescribed, we cannot have the word bhüta. This is solved by saying that the word bhüta is actually nitya "eternal, existing in the usage," and the science of grammar only explains 
the existing words. Also see: MB-P-, Vol. I, Sec. I, p. 63.

151. Misra (1966), p. 105.

152. vākyāparisamāpter vā, Vārttika $\underline{4}$ on P.1.1.10, $\underline{\mathrm{MB}}$, Vol. I, Sec. I, p. $1 \overline{61}$.

153. varnānām upadeśas tāvat/ upadeśottara-kālet-samijñā/ it-samjjñottara-kāla 'ādir antyena sahetā itî pratyāhārah/ pratyāhārottara -kālā savarna-samijña/ savarnasamjñnottara-kālam 'anudit savarnasya cāpratyàya' iti savarna-grahanam/etena sarvena samuditena vākyena anyatra savarnānām grahanam bhavati/ MB, vol. I, Sec. I, p. 161 .

154. anumānam dvividham svārtham parārtham ca/ ... yat tu Svayam dhūmād agnim anumāya para-pratipatty -artha m pañcāvayavaì văkyam prayuñkte, tat parārthānumānam/ yathā parvato vahnimān dhūmavattvāt yo yo dhūmavān sa vahnimān yathā mahānasah/ tathā cāya m/ tasmāt tathāiti TS , p. 37 .

155. tatah 'ādir antyena sahetā' iti pratyāhāra-siddhih/ tato

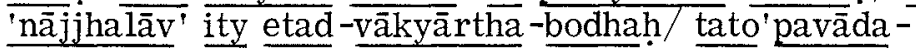
visaya-parihārena savarna-samjñā-niscaye sati grahanaka -śāstra-pravrttị̂ na tv etat-sūtra-nispattisamaye/ SKB, p. 121.

156. niședha -paryālocanami vinā notsargasya vākyãrtho lakșye pravrttis ca/ 'kniti ce' ti sūtre nisedha -sūtrānām paribhāșātvāngīīārenaikavākyatāyā eva yuktatvāt/ nājjhalāv iti sūtrāt pürvam ikārāđișu samijñāa-pravrttisamaye ajjhalor api pravrttatvena bhuktavantam prati mā bhuninthāh iti vākyasyeva niședha -vākyasya vaiyarthyāpatteh BSS. Vol. I, p. 68 .

157. tathā caitat-paryālocanottaram savarña -padārtha -jñāne jāte'nudit ity asya vākyārtha-bodhaḥ vākyārtha -bodhe padärtha -jñānasya kāranatvãt $\ldots$ vākyasya aparisamāptatvam ca savarna-pada -vācya-nirnayam vinā savarna-grahana-bodhanāsämarthyam iti bodhyam BSS, Vol. I, p. 68 .

158. itah pürvam grahanaka-śāstram eva na nispannam iti katham na paryālocayeh SKB, p. 122; also: PM, p. 53 . 
159. a -i -u -ṇ, nājjhalāv ity ādau dīrghādināma na grahanam, tat-pranayana-kãle tad tarthasyaiva ajñānena hrasvābhiprāyenaiva prayuktatvāt/ BSR, p. 13 .

160. Thieme (1935b), p. 206.

161. iha tu nāsti grahanam 'anudit savarnasya cāpratyaya' iti / ki $\dot{m}$ kāranam? asmin grahane aparini spannatvāt

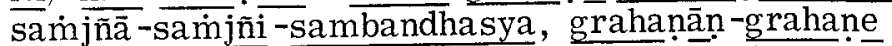
grahanābhāvah, grahanaka -śāstrasya anabhinirvirttatvāt, grahanāntarasya cābhävāt, svātmani ca kriyā-virodhāt tatra hi an-grahane grahanaka -śāstram anabhinirvrttam, kriyamānatvāt samjōñ-samjūi -sambandhasyă

grahanāntaram ca nāsti svātmani ca kriyā viruddhyate/ yathā ghato nātmānam saknoti sprașțum/ MB (Swaminathan's edn.).

162. İsad ity asyānanuvrttim samāna -prayatnatām ca svikrtya

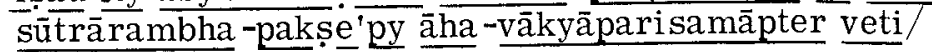
SKB, p. 121.

163. ākārasya tapara-karanam savarnārtham, bhedakatvāt svarasya, Vãrttikas $13-\underline{4}$ on P.1.1.1, MB, Vol. I, Sec. I, p. 113 .

164. abhedakā gunā ity eva nyãyyam/ kuta etat/ yad ayam asthidadhi -sakthy -akșnām anañ udātta ity udātta -grahana ma

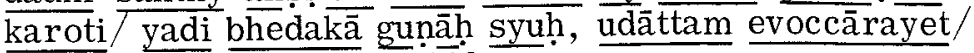
MB, Vol. I, Sec. I, p. 113 .

165. asandehārthas tarhi takārah/ MB, Vol. I, Sec. I, p. 114.

166. an savarnasyeti svarānunāsikya $-k a \overline{l a}$-bhedāt, Vārttika 1 on P.1. 1.69 , $\overline{\mathrm{MB}}$, Vol. I, Sec. I, p.

167. taduktam் vārttika -kārena -ākārādīnām tapara -karanạm savarnārtham, bhedakatvāt svarasya iti an savarnasyeti svarānunā sikya -kāla -bhedād iti uktavato bhedakatvam $\overline{\text { evābhipretam/ sūtrakārasya }}$ ca savarne' ñ -grahanāt... bhedakatvam apy astity anumīyate/, MB $-\underline{D}$, p. $15 \overline{5}$.

168. atredam bodhyam/ vyaktih padārtho gunāh bhedakā ity abhimānenātra sūtre'ñ-grahanam iti L LSS,$\overline{\text { p. } 132 .}$

169. anudit-sūtre'n-grahanād anityeyam iti dhyeyam/

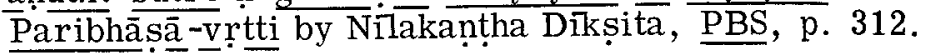


170. abhedakā udāttādaya iti siddhāntasya ca te savarna samjñ̄a -bhedakatvena na vivaksitā ity arthah/BSS, Vol. I, p. 47.

171. See: n. 19.

172. tatrānuvrtti -nirdeśe savarnāgrahanam anantvāt, Vārttika, MB, Vol. I, $\overline{\text { Sec. I, p. } 66 .}$

173. ekatvād akārasya siddham, Vārttika, MB, Vol. I, Sec. I, p. 66 .

174. ākrti -grahanāt siddham, Vārttika, MB, Vol. I, Sec. I, p. $\overline{70}$.

175. rūpa -sāmānyād vā, Vārttika, MB, Vol. I, Sec. I, p. 71.

176. nanu ca savarna -grahanenātiprasaktam iti krtvā taparāh kriyeran $7 \ldots$ pratyākhyāyate tat-'savarne'n -grahanam

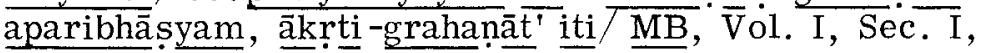
p. 71 .

177. eko'yam akāro yaś cākșara-samāmnāye, yaś cānuvrttau, yaś ca dhātv -ādi-sthah $\overline{\mathrm{MB}}, \overline{\mathrm{a}}$, Vol. I, Sec. I, p. 66 .

178. ekaivākāra -vyaktir udāttādi -pratibhāsas tu vyañjaka dhvani -krtah/ MB-p, Vol. I, Sec. I, p. $\overline{66}$.

179. yadi punar ime varnāh -ādityavat syuh, Vt. --tad yathādityah anekādhikaranastho yugapad desa -pr thaktvesu upalabhyate MB, Vol. I, Sec. I, p. 66. punar apy ekatva-nityatve sādhayati/MB-P-U, Vol. I, Sec. I, p. 70. Compare: ādityava yaugapadyam, MS 1.1.15, and yat tv eka -deśasya sato nānā-deśeșu yugapad darśanam anupapannam iti/ âdityam paśya devānām-priya ekah sann aneka-desāvasthita iva laksyate/ Śabara on $\overline{\mathrm{MS}}$, Vol. I, Pt. I, p. 80. Also: Biardeau (1964), p. $\overline{178} \mathrm{ff}$.

180. Viśveśvarasūri clearly says: tasmād astāādaśaivākāravyaktayo nityāh, VSSN, p. 83. He has a detailed discussion of the Nyāya and Mīmāmsā views on this point [ibid. pp. $77 \mathrm{ff}$. ]

181. kāryatve nityatāyām vā kecid ekatva -vādinah/kāryatve

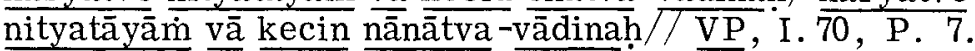
The commentary Ratnapraka sa on the $\overline{M B}$ says that those who consider that there is only one sound individual must 
accept sounds to be eternal, and those who consider that there are many sound individuals must accept that sounds are non-eternal. Those who accept that there are many sound individuals and yet accept that sounds are eternal have not properly understood the meaning of the Bhāșya. [eka -vyakti -vădinām mate hi varnānām nityatāva śyābhyupeyā/ aneka-vyakti-vādi -mate tv anityataiveti /...evam cāneka-vyaktikatva -paksépi

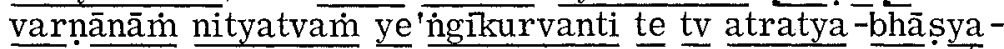
sva -rasānabhijñā bhrāntā eveti spastâm eva sudhiyām/ Ratnaprakāśa, M $\overline{P V}$, p. 132.$]$

182. vyakti -pakse grahanaka-șāstrārambhāt/ MB-P, Vol. I, Sec. I, p. 63; also: vyaktih padārtho gunā bhedakāh ity abhimānenātra sūtre'ñ-grahanam/ LSS, p. 132.

183. ekā avarna-vyaktir iti pakșe tu yady api siddhyati/ $\overline{\mathrm{MB}}-\overline{\mathrm{P}}-\underline{\mathrm{U}}$, Vol. I, Sec. I, p. $\overline{37}$.

184. ānya -bhāvyam tu kāla -śabda -vyavāyāt and yugapac ca deśa -prthaktva -darśanāt, Vārttikas, MB, Vol. I, Sec. I, p. 69 .

185. ānya -bhāvyam tv akārasya kāla -śabda -vyavāyāt/... kāla -vyavāyãt -danḍa agram/ sabda -vyavāyāt-danḍah/na caika syātmano vyavāyena bhavitavyam/ bhavati cet, bhavaty ānya-bhāvyam akā $\overline{\text { rasya }}$... yugapac ca deśa prthaktva-darśānān manyāmahe -ānya-bhāvyam akārasyeti/ yad ayam yugapac ca deśa -prthaktvesuupalabhyate/ aśvah, arkah, arthah iti / na hy eko devadatto yugapat srughne

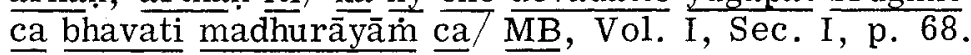

186. tad yathā tān eva śātakān ācchādayāmặ, ye mathurāyām, tān eva śālin bhuñjmahe, ye magadheșu tad evedam bhavatah kārsāpanam yan mathurāyāim gṛhitam, anyasmimís cānyasmìiśs ca rūpa -sāmānyãt tad evedam iti bhavati evam ināpi rūpa-sāmãnyāt

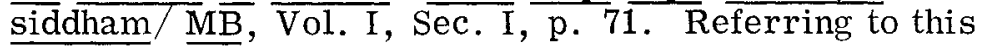
passage, the commentary Ratnaprakāsa says that similarity (sādrśya) in this context has to be accepted in a specific sense: there should be difference of two individuals with identity of all properties. [tatra sādr șyam sarva-dharma-sāmye sati vyakti -bheda -prayuktam grāhyam, Ratnaprakāsa, MPV, p. 121.] 
187. rüpa-sāmānyād vāa katham ayam parihārah / tatra kecid varnayanti/yady apy ākrtir naiva syãd evam api na dosah/ yathâ kārșāpanādisv asatyām jātau bhavatas tâvan mathurāyām kārsāpanam asty atha cārtha -vastv eva/ MB-D, p. 58 .

188. siddham tv avasthitā varnā vaktuś ciräcira-vacanäd vrttayo viśisyante, värttika on P.1.1.70.

189. See: n. 166.

190. See: n. 188.

191. hrasva -dīrgha-plutās tu svata eva bhinnā bhinnair dhvanibhir abhivyajyanta iti tesām kāla-bhedah/MB-P, Vol. I, Sec. I, p. 378. Nāgeśa totally reinterprets Kaiyața: kaiyațe hrasva-dirgha-plutās tu svata eva bhinnā ity asya vyañjaka -bhedenāropita -bhedā eva bhinnair dhvanibhir vyajyanta ity arthah $/ \mathrm{MB}-\overline{\mathrm{P}-\mathrm{U}}$, Vol. , Vol. I, Sec. I, p. 379 . This is not true to Kaiyata's intention.

192. varnāntaratvam evāhuh kecid dīrgha -plutādișu, Kumārila's Sloka -vārttika, Sphota-vāda section, verse $4 \overline{5}$.

193. Svabhāva -bhedān nityatve hrasva -dīrgha-plutādișu/ prākrtasya dhvaneh kālah sabdasyety upacaryate 7 sabdasyordhvam abhivyakter vrtti -bhedam tu vaikrtāh/ dhvanayas samupohante śabdātmā tair na bhidyate $/ 7$ VP, I. 76-77. See: 'Whereas length in terms of the time required for utterance (duration or quantity) is a phonological parameter according to some modern linguists, the parameter of temporal length is not applied by the Panninians in determining the varnas. In other words, the former may hold that the difference between $/ \mathrm{u} /, / \overline{\mathrm{u}} /$ and $/ \overline{\overline{\mathrm{u}}} / . .$. is phonemic in Sanskrit, for a variation in meaning results when one is substituted for the other in some minimal pairs; for example, pura. 'city' and pūra 'flood.' But a Päninian does not hold that $/ \mathrm{u} /, \overline{\mathrm{u} /}$ and $/ \overline{\mathrm{u}} /$ are three distinct varnas of the Sanskrit language; he reduces all these forms to a sort of common-factor form in his list of the varnas and sees two different realizations of one varna in pura and pūra. Thus, he attributes the difference in temporal length to 
the sound-substance rather than to the entity which the sound-substance manifests." Aklujkar (1970), p. 10. This needs to be modified slightly. Pānini and Kātyāyana considered length etc. to be distinctive features [ see: Sec. 6.5-8 and Sec. 6.12 above] . The Pāniniya-śikșā [verse 3] says: trișastiś catuhsastir vă varnāś sambhumate matāh "In the view of Siva, there are sixty -three or sixty-four varnas 'sounds. "' Here, we have to count short and long vowels as separate varnas. Even in the Prātiśākhyas, we find short and long vowels listed separately. At the same time, there exists a higherlevel notion of varna "sound-class," which is seen in the affixation of -varna to short vowels to include long varieties. However, this class-notion is not contradictory to short and long vowels being phonemically distinct. The higher notion of varna, or the notions of savarna -grahana or Kātyāyana's varnākrti are all supra-phonemic notions. They are rather convenient ways of grouping sounds which are phonemically distinct from each other. These notions are in the background of Bhartrari's notion of sphota, which also stands on a supra-phonemic level. Bhartrhari himself considered features of length etc. to be phonemically distinctive, though they were not distinctive at the supra-phonemic level of sphota [see: Sec. 6.13].

194. Deshpande (1972), pp. 226-7.

195. Ibid., p. 233.

196. Ibid., p. 239.

197. Thieme (1958), p. 33.

198. Ibid.

199. agrhhīa-savarnānām eva nājjhalāv iti niṣedha iti sthitam/ SKB, p. 123. Viśveśvarasūri [VSSN, p. 242] refers to a difference of opinion between Kaiyața and Bhattoji

Dikșita. Kaiyata says that P.1.1.10 is needed to avoid undesired homogeneity between $/ \mathrm{a} /$ and $/ \mathrm{h} /$, and $/ \mathrm{i} /$ and $/ \mathbf{s} /$. Bhattoji adds to this $/ \mathrm{r} /$ and $/ \mathrm{s} /$, and $/ 1 /$ and $/ \mathrm{s} /$. These two cases are not mentioned by Kaiyata. Viśveśvarasūri says the Kaiyata accepted the $\mathrm{RPr}$ view 
that $/ \mathrm{r} /$ and $/ 1 /$ are both jihvāmūlìya "produced at the root of the tongue, " and hence they cannot be homogeneous with /s/ and /s/, which are cerebral and dental respectively. Viśveśvarasüri believes that the same view was shared by Pānini and Kātyāyana. He also points out [VSSN, p. 244] that if P.1.1.69 were to apply to P.1.1.10, different varieties of /a/ will not be homogeneous with each other.

200. evam ikāro'py atrekārena na grhyata iti ikāraSakārayoh savarnatvam asti/ MB-P, Vol. I, Sec. I, p. 161.

201. yad etad 'akah savarne dīrgha' iti pratyāhāra -grahanam, tatrekāra ikāram gṛhnāāi, śakārạ na grhnnāti MB Vol. I, Sec. I, p. $1 \overline{61}$.

202. atra ca na ikaro gṛhīto nāpi śakāra iti ikāra-śakārayoh

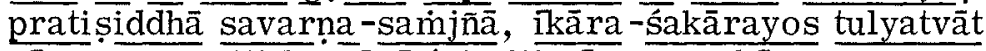
sāvarnyam, iti kumāri śete iti sāvarnya-kāryam ekādeśah prāpnoti/ aj-adhikārān nivartate/ MB-D, p. 153 .

203. MB-P, Vol. I, Sec. I, p. 161; KS, Vol. Iv, p. 571; SKB, p. 123; Rūpāvatāra, Pt. I, p. 11; PrakriyāKaumudi, Pt. I, pp. 67-8; SK, p. 7.

204. yadā tūṣmanām ișad-vivṛtatvam āśritya 'nājjhalāv' iti sūtram pratyākhyāyate, tadeha 'aci' iti nänuvartaniyam/ PM, p. 173. Also: BSS, Vol. I, p. 205.

205. katham punar idam pratyudāharanam upapadyate, yāvatāa 'anudit savarnasya cāpratyayah' ity atra hakārena ākāro gṛhyata iti/ asti hy ākārasya hakāreña saha savarnatvan̉ tulya-sthāna-prayatnatvāt/ sthānam asti hy anayos tulyam iti 'akuhavisarjaniyāh kanthyāh' iti prayatno'pi tulyah - vivrtam karanam üsmanäm svarānām ca iti tasmāt saty apin̄kor iti prāpnoty eva mūrdhanyah, 'nājjhalāv' iti savarna-samjñāa- a] -pratiședhād 'iti cet,

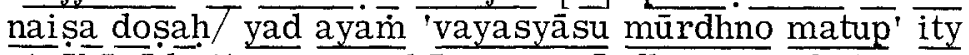
atrākārä̀ uttarasya sakārasya mūrdhanyam akrtvā nirdeśam karoti, tato'vasīyate hakāro grhyamāno nākāram grāhayati; anyathā 'vayasyāsu' iti nirdesam na kuryāt/. KS-N, Vol. 6, p. 544 . 
206. yathā... ināara-śakārayoh sāvarnyam apratișiddham tathā a akāra-hakārayor api tatah kim ? hakärenākārasya grahanāt șatva-prasañgah? naisa dosah, hakäro vivrtah, âkāro vivrtatarah/ . . . evam ca kr retvā "istakāsu, 'vaya syāsu' ity ädayo nirdesa upapadyante/ KS $-\underline{P}$, Vol. 6, p. 544 .

207. evam sthite 'mālāsu' ity ādau satvam na syāt/ hakārenākāra-grahane sati 'gaurīsu' ity ầivat inah

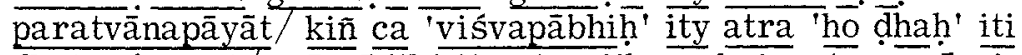

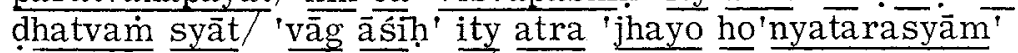
iti ākāra sya ghakārah syāt/ 'gāsídhvam, ity atra 'inah șídhvam' iti mūrdhanyādesah syāt/'dāsissta ity āau 'dāder dhātor ghah' iti ghatvam syāt 'räma ayāti' ity âdau 'haśi ca' ity utvam syāt/ devā āyānti' ity ādau 'hali sarveșām' iti nityo yalopah syât 'cākhâyitā' ity $\overline{\mathrm{a} d a u}$ 'yasya halah' iti yalopah syāt/'śnenāyitā' ity ādau 'kyasya vibhāsā' iti lopas syät 'niccāyya' ity atra 'halo yamām yami lopah' iti yalopaś ca syāt iti bahūpaplavaprasangah/ $\overline{\mathrm{KB}}, \mathrm{p} . \overline{12}$.

208. yiyā3so ity ādau 'guror anrtah' iti plutād ākārāt parasya sanah șatvam/ SKB, pp. $12 \overline{3}-4$. Also: PM, p. 53 .

209. atrocyate -ākāro na hakārasya savarnah 'tato'py ākārah' ity a-i-u-ñ-sūtrodāhrta-śikșā -rityā bhinna -prayatnatvāt/ 'savarne'n-grahanam aparibhā syam âkrti-grahanāt' iti vārttika-mate tu hakā rākārayor eka - jāty -anākrāntatvād eva nātiprasañah / yad vā ākāra-sahitah ac āc, sa ca hal ca âjjhalāv iti sūtre $\overline{\bar{a} k a r a-p r a s ́ l e s o ~ v y a ̄ k h y e y a h ~} 7$ tenākārasyācām ca halbhị saha sãvarnyam nisidhyate/ ākāra-praślese liñgam tu 'kāla -samaya -velāsu tumun' ity ādi -nirdesẩ̆ atra pakse āś ca ā3ś ceti dvandvena savarna -dīrghena ca 'nājjhalāv' iti sūtre dírghāt parah

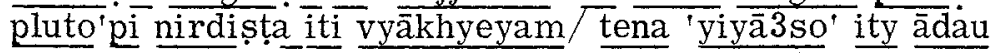
'guror anrtah' iti plutād ākārāt parasya sanaḥ satvam nety avadheyam 7 bhāsya -mate tūsmanām isad-vivrtatā bhyupagamena sāvarnya-prasaktir eva nā stīti sūtra-

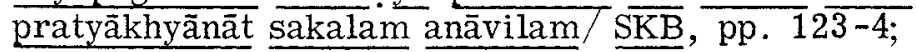
also PM, p. 153 .

210. ākāra-praśleșe lingam tu 'kāla -samaya -velāsu tumun'

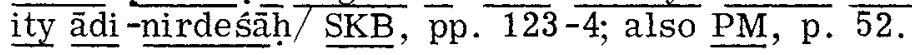


This device of inserting a sound in the rule to yield a new interpretation is not unfamiliar in the Pāninian tradition. Kielhorn comments: "A long or even a short vowel often results from the coalition of two or more vowels. How this simple fact may be turned to account in grammatical discussions, may be seen from the following examples. In Vol. I. p. 501, Kātyāyana states that the single vowel $/ \bar{a} /(d \bar{a})$, which by P.II. 4.85 is substituted in the Periphrastic Future for the ordinary personal terminations ti and ta, takes place of the whole original termination (and not merely, according to P.I.1.52, of their final letters), because $/ \bar{a} /$ may be regarded as a combination of the two vowels $/ \bar{a} /-/ \bar{a} /$; and that for this reason Pānini is justified in not attaching the Anubandha / $/$ to the substitute dā (compare P.I.1.55). According to Patañjali, Pănini might similarly have omitted the Anubandha $/ \dot{s} /$ of the term as in P.II.4.32 (Vol. I, p. 481), and of the term as in P. VII. 1.27 (Vol. III, p. 251), because even (short) /a/ may be regarded as a combination of $/ \mathrm{a} /-\mathrm{a} /$. According to Patañjali, again, loka - in P.II. 3.69 may be regarded as the result of the combination $/ \mathrm{la} /-/ \mathrm{u} /-/ \mathrm{uka} /-$, and no additional rule is required to teach that words like cikirsu, which are formed with $/ \mathrm{u} /$, are not construed with the genitive case (Vol. I, p. 469)." Kielhorn (1887), p. 248. Kielhorn also rightly expresses his doubts about the validity of such interpretations [Kielhorn (1887), p. 245].

211. ukta -nirdeśād eva sāvarnyyābhāvasya kalpane tu ānumānika vacana-kalpanāpātah/ pada -vibhāga -mātra tātparya kalpane tu na kiñcid gauravam/BSR, p. 52. Also: LSR, pp. $5 \overline{2}-\overline{3}$. Nā rāyanabhatța in his Prakriyā-sarvasva accepts that Pănini's usages are sufficient to avoid homogeneity of $/ \bar{a} /$ and $/ \mathrm{h} /$, and there is no need to reinterpret P.1.1.10. [nājjhalau ity atra dīrgha-haloh sāvarnyānisedhāt ākārasya hakārena savarna-grahāt intvena 'somapāsu' 'ramāsu' ity àdau satvam prāptam 'vayasyā su mūrdhno matup' iti nirdeśān na syāt/ $\overline{\text { Prakriyā-sarvasva, }} \overline{\text { Pt. IV }}, \bar{p}$. 150: also: S. Venkata Subromonia (1972), p. 102.] This is similar to Jinendrabuddhi's view. See: n. 205. 
212. rephosmanāim savarnā na santi/MB, Vol. I, Sec. I, p. 88. Limaye (1974, p. 46) considers this to be a quotation from the Apiśali-śikșā. He considers several lines from the MB as being quotations from this text [ibid., pp. 56-8].

213. Abhyankar (1969), p. 100.

214. vrrttau bhāsye tathā dhātu -nāma -pārāyanādisu viprakirna sya tantrasya kriyate sāra-samgrahah// KS, Vol. $\overline{\mathrm{I}}, \mathrm{p} .3$.

215. "...the compilers of the Kăsika have diligently used that grammar (i.e. Cāndra-vyākarana), although they never mention it." Kielhorn, "The Chandra-Vyākarana and the Kāsikā-vritti, "The Indian Antiquary, June, 1886, p. 184 .

216. Quoted in Kielhorn (1891), p. 107.

217. S. C. Vasu (1891), Vol. I, p. 13.

218. Renou (1966), Vol. I, p. 5.

219. Böhtlingk (1887), p. 3 .

220. On the history of the interpretation of halantyam (P.1.3.3), see: Thieme (1957a), pp. 51-3.

221. [A]: P.1.2.45 (arthavad adhātur apratyayah prātipadikam),

P . 8.3.41 (idudupadhasya cāpratyayasya).

[B] : 1) apratyaya iti cet tib-ekâadeśe, Vt. $\underline{13}$ on P.1.2.45.

2) cino luki ta -grahanānarthakyam saminhātasyã pratyayatvat, Vt. 1 on P.6.4.104.

3) lumati pratyaya-grahanam apratyaya -samjñāpratisedhārtham, Vt. 1 on P.1.1.61.

4) yathāgṛhitasyādes sa -vacanād apratyayasthe siddham, Vt. 4 on P.6.1.13.

5) mamaka -narakayor upasamkhyānam

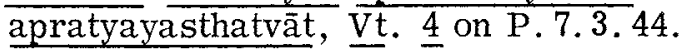

222. Deshpande (1972), 1p. 237-8 and 242-3.

223. KS, Vol. 1, p. 244. As an example, KS cites the affixes $/ u /$ and $/ a /$ taught by P. 3.2. 168 and P.3.3.102. But in other places, it again seems to accept the 
Maxim [1], see: KSS, Vol. 5, p. 631. 224. Renou (1966), Vol. I, p. 21.

225. Deshpande 91972), pp. 224-5 and 242-3.

226. Pānini's rules do not allow a substitute sound to be given with both the markers, i.e. $/ \dot{\mathrm{S}} /$ and $/ \mathrm{T} /$. The marker /S/ with a substitute shows that the unit with /S $/$ replaces the whole substituendum and not just the final sound [i.e. P.1.1.55 (anekāl-śit sarvasya)] . This obviously means that with reference to substitutes marked with $/ \hat{S} /$, the rule P.1.1.50 (sthãne'ntaratamah) does not apply and the substitute as given will be effected. Therefore, Patañjali's argument concerning P.2.3.3 (idama is ) is a weak argument.

227. Deshpande (1972), pp. 237-8, 242-4.

228. Ibid., pp. 208-210.

229. 1) P. 8. 4.66 (ur at), all $/ \mathrm{r} />$ short $/ \mathrm{a} /$.

2) P. 7.4.95 (at $\operatorname{smr} r-d \bar{r} . ..), / \bar{r} /($ in $d \bar{r})>$ short $/ a /$.

3) P.1.2.17 ( sthā-ghvor ic ca), $/ \bar{a} />$ short $/ \mathrm{i} /$.

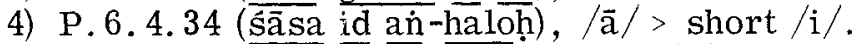

5) P.1.2.50 (id gonyāh), $\overline{\mathrm{i}} />$ short $/ \mathrm{i} /$.

6) P.6.4.114 (id daridrasya), $/ \bar{a} />$ short $/ \mathrm{i} /$.

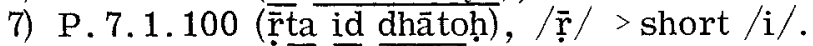

8) P. 7.4.40 (dyati -syati -māa -sthām it ti kiti), $\overline{\bar{a} />}$ short $\bar{i}$.

9) P. 7.4 .7 (ur r r $\underline{\text { t) }}$, all $/ \mathrm{r} />$ short $/ \mathrm{r} /$.

230. Deshpande (1972), pp. 236-7.

231. astañ-janādi -pathi -mathy -ātvesv āntaratamyād anunāsika -prasañgah, vt. 1 on $\bar{P} \cdot \overline{7.2 .84}$.

232. Kaiyata has the following comment on this vārttika: anantvād eva bhāvyamano'n savarnān na gṛnnātíti parihāro noktah, MB-P, vol. III, p. $\overline{15} \overline{8}$. "[ Kātyāyana does accept the Maxim (1), but] the solution that an introduced / $\mathrm{a}-\mathrm{N} /$ sound does not represent its homogeneous sounds is not offered, simply because [the substitute $/ \bar{a} /$ is ] a non-/a-N/ sound." Kaiyata's assumption has no base. 
234. Patañjali on P.6.1.185 says: "The procedure of the teacher indicates that an introduced / $\mathrm{u} /$ does represent its homogeneous sounds, since Pānini attaches $/ \mathrm{T} /$ to /u/ in P.6.1.131 (diva ut)." [ācārya -pravrttir jñāpayati bhavaty ukārena bhāvyamānena savarnānām grahanam iti yad ayam diva ut iti ukāram taparam karoti/ $\mathrm{MB}$, $\overline{\text { Vol. II }}$, p. 801.] Nāgeśa [MB $-\underline{P-U}$, Vol. II, p. 801$]$ offers P.6.1.111 (rta ut) as an indication for the same maxim.

235. Deshpande (1972), pp. 237-8, 242-3.

236. For instance, if the Maxim [2] is accepted, it will also apply to $/ \mathrm{u} /$ affixes which are introduced, and then they would also represent their homogeneous varieties. Thus, it would be necessary to make a separate statement to exclude them.

237. Paribhāsā-sūcana, PBS, p. 15.

238. Ibid., p. 16.

239. PBS, Intr. pp. 12-3.

240. dravyābhidhānam vyādih, Vt. on P.2.1.1.

241. See: Sec. 8.8 and n. 132. For more arguments, see: Deshpande (1972), p. 226, Fn. 37.

242. S. D. Joshi (1969), Intr. p. 10.

243. Paribhäsā-sūcana, PBS, p. 25. K. V. Abhyankar, the editor, quotes another reading in the footnotes: anudit savarnam eva grhnāti na varna-mātram. This is not supported by the auto-commentary [see: n. 244], and also its sense makes it redundent.

244. udit varno gṛhyamānah sva -vargam eva gṛhnāti na savarna -mātram/katham jñāyate/ yad ayam 'na vibhaktau tusmāh (P.1.3.4) ity atra tu-grahanāa eva siddhe sakãrasya grahanạm karoti / kim etasyā jñāpane prayojanam/'coh kuh' (P.8.2.30) ity atra cu-grahanena Sakārasyāgrahanāa kutvam na bhavati, tena viọ iti siddham bhavati I Ibid., p. $\overline{26}$.

245. The rule APr I.33 is given by Whitney as eke sprsțam and interpreted to mean that, according to some, vowels 
are with contact. In that case, the spirants may as well be with contact. However, the true reading of this rule is eke asprstam "According to some, the vowels are without contact." [For details, see: Madhav Deshpande, "New Material on the Kautsa-vyākarana," appearing in the Journal of the Oriental Institute, Baroda. ] The TPr, in a way, classifies stops, semi-vowels and spirants together as involving sparśana (ii.33) "contact," as opposed to vowels which have upasamhāra (ii.31) "approximation." But later we find in TPr (ii.45) that the middle of the articulator is vivrta "open" in the case of spirants. This distinguishes spirants from other consonants.

246. Brrhat-paribhāsāā-vrtti, PBS, p. 179.

247. udid varnah 'anudit savarnasya' (P. 1.1.69) iti sthānaprayatnäbhyām viśistam eva savarnam grhnāiti na savarna-

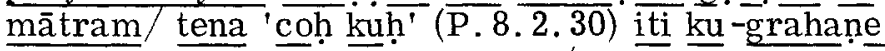
hakārasya grahañam na bhavati j jñāpakam cātra 'na vibhaktau tu-smăhT(P.1.2.4) ity atra tu-grahana $\overline{\text { ma }}$ krtvā sakāra -grahanam iti/ ayam ca nyāya-siddha evärthah sukha-pratipatty -artham jñ̄āpakenoktah/Ibid., p. 179.

248. udit savarnạm gṛhnāti na savarna -mātram/(17)/ mātra-

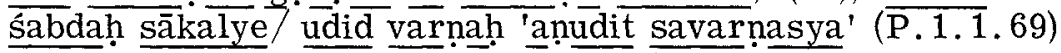
iti sūtrena sthāna-prayatnābhyām vi śisțam eva savarnam grhhnāti, na tu sthānaika-tulyam savarna -mâtram/'na vibhaktau' (P. 1.3.4) ity atra vargāt prthak sakāragrahanāāl lingāt/ 'tulyāsya-prayatnam' (P.1.1.9) iti sthāna-prayatna-viśisțasyaiva savarna -samjñābhidhānād vā/ tena 'coh kụ ' (P. 8.2.30) ity adau na hakārādividhị̆/ Paribhāsāa -bhāskara by Haribhāskara Agnihotrin, PBS, p. 329 .

249. udit savarnạm grhṇāti (131)/ na savarna -mātram/ sthāna -mätra -tulyam savarnam grhnāitīy arthậ. viśișta syaiva savarna -samjnā -vidhänād bhāsye darsanāc ceyam prakșiptā/... atha prakșiptā nirmūià ś ca

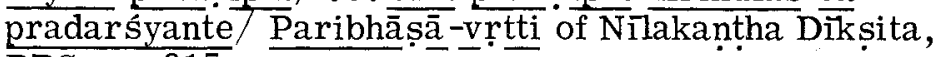
PBS, p. 315 .

250. Burnell (1875), p. 47, extensively quotes from Martin Haug. Also: Kielhorn (1876b), p. 142. 
251. Burnell (1875), pp. 47, 50 .

252. Kielhorn (1876b), pp. 142-4.

253. Ibid. Franz Kielhorn in his "Indragomin and other Grammarians" [Indian Antiquary, Vol. 15, June 1886, pp. 181-3] discusses Burnell's views on the Aindra School of Grammar. He says: "I have indeed been long aware of the fact that a grammar composed by Indra must have existed, because I knew that that grammar had been used by Hemachandra. But as the fuller name of the author of that work is Indragomin, just as Chandra's fuller name is Chandragomin, I feel no inclithation to make it older than Pānini." (p. 181) "I would urge my fellow students to cease speaking of an Aindra grammar, or of the Aindra School of grammarians, terms for which, so far as I know, there is no justification, and which are only apt to mislead." (p. 183) Despite Kielhorn's warning, there are enough references to the Aindra grammar that existed before Pānini to justify acceptance of such a possibility. It is also possible that Indragomin's grammar was different from this ancient Aindra grammar, just as the pre-Pāninian Śâkatāyana is different from the post-Pạninian Jain S̄ākațāyana.

254. "That this science is warranted as much by general reasons as by the explicit reference made to it in the TU 1.2 must not be confounded with the well known treatises going by the name of Sikșā need hardly be repeated. They are all of them, young elaborations of the definitions laid down in the Prātisasakhyas." Thieme (1935a), pp. 85-6. [The abbreviation TU stands for Taittiriya -Upanișad. ]

255. Cardona (1965a) presents a brief discussion of the notion of savarṇa in the Prātisâakhyas.

256. hrasvādeś hrasva -dírghau savarnau, RPr, 1st Patala, verse $13, \mathrm{p} .7$.

257. The sound $/ 1 /$ would be excluded because there is no long $/ \overline{1} /$. Though the RPr does not say it explicitly, this can be inferred. The sound $/ 1 /$ occurs only in the forms of 
the root $\mathrm{kl} l \mathrm{p}$, where also it is considered as a transformation of $/ \mathrm{r} /$ [ madhye sa tasyaiva lakāra-bhāve dhātau svarah kalpayatāv rkāraḥ, RPr, 13th Patala, verse $14, \mathrm{p} .56]$. It never occurs either at the beginning or at the end of a word [ padādy -antayor na lkärah svaresu, RPr, Upodghāta, verse 9, p. 3]. Thus, there is no chance of obtaining long $/ \bar{l} /$.

258. pañca te pañca vargäh, $\underline{R P r}, 1$ st Pațala, verse 2, p. 5 .

259. savarna-pūrvasya para-dhruvasya..., RPr, 6th Patala, verse $\overline{12}$, p. 31 .

260. samānākșare sasthāne dīrgham ekam ubhe svaram, RPr, 2nd Patala, verse 6, p. 9 .

261. Svarānusvārosmanām asprșțaim sthitam, RPr, 13th Patala, verse 3 , p. 55. Also see: "The $\overline{\mathrm{Rk}}$. Prāt. also fails to note any difference of quality between the long and short values of this vowel (i.e. /a/). But it is very doubtful whether we are to regard the silence of these two treatises upon the point in question as any evidence that they are of notably earlier date than the others, as Weber seems inclined to do: their peculiarity is much more likely to be due to a local or a scholastic difference of pronounciation, or they may have simply disregarded as of little account, the discordance of quality between /a/ and /a/." Whitney on APr, p. 32. Max Walleser (1927) has considered these alternatives and he concludes as follows: "Mir scheint nun nur die an zweiter Stelle gegebene Erklärung angängig zu sein, nämlich die Annahme, dass der Unterschied in der Aussprache schon in der ältesten Zeit bestanden habe, aber erst nach der Zeit der Rk. und Taitt. Pr. bemerkt worden ist, und Zwar aus vier Gründen: ...," p. 195. I tend to agree with his general conclusion [see my "Phonetics of Short /A/ is Sanskrit," appearing in the Indo-Iranian Journal], but his "vier Gründe" are not very convincing. He seems to believe that no sound-changes are heard of or have been observed within the "Literaturschicht der Prātiśâkhyen," and that the Vedic speech being a dominating "Kultsprach," any organic sound-changes were generally unlikely. The arguments adduced by 
him to prove that the short /a/ was a closed sound are based on the fact that the Sanskrit /ă / represents IndoEuropean /a/, /e/ and /o/. They are interesting, but not conclusive.

262. dve dve savarne hrasva -dīrghe, TPr (i.3), p. 11.

263. teșu samānāksaresu dve dve hrasve, dve dve dīrghe, hrasva dírghe, dīrgha -hrasve vākșare parasparam savarna-samjne bhavatah, Tribhăsya-ratna, TPr, p. 11.

264. atha navāditah samānākșarāni, TPr (i.2), p. 10 . Contrast: aștau samānăksarāny āditah, RPr, 1st Patala, verse $1, \mathrm{p} .5$, referring to $/ \mathrm{a} /, \overline{\mathrm{a}} /, / \mathrm{i} /, / \overline{\mathrm{i}} /, / \mathrm{u} /, \overline{\mathrm{u}} /$, $/ \mathrm{r} /$ and $/ \overline{\mathrm{r}} /$.

265. na pluta-pūrvam, TPr (i. 4), p. 2.

266. samjñ̄āyāh prayojanam 'dīrgham samānākșare savarnapare' (x.2) iti, Tribhäsya-ratna, TPr, p. 11.

267. Whitney on TPr, p. 11.

268. iyam anvartha -samjñā/ savarnatvam nāma sādr śyam ucyate/ tasmād akārādinām ikārādibhir na savarna-

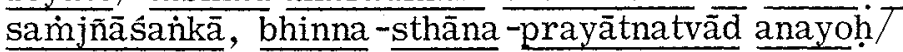
samjjñāyāh prayojanam 'dīrgham samānākșare savarna-

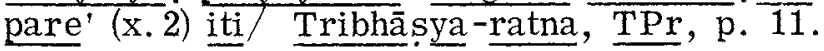

269. varnah kārottaro varnākhyā (i.16), TPr, p. 18. hrasvo varnottaras trayānām (i.20), TPr, p. 20. prathamo vargottaro vargākhyā (i.27), TPr, p. 25.

270. Whitney on TPr, p. 21.

271. TPr, p. 383 .

272. Tribhāsya-ratna, TPr, p. 383 .

273. Whitney on TPr, p. 385.

274. TPr, p. 307.

275. savarna-parah savargìya-paraś ca dvitvam nāpadyate/ savarnás ca nāma sārūpyam ucyate / na tulya -sthānakaranatāan-mātram, savargìa h samāna-varga - sambandhi// Tribhäsya-ratna, TPr, p. 308; Whitney on TPr, pp. 307-8; Cardona (1965a), p. 234. 
276. TPr, pp. 148-9; Cardona (1965a), p. 233.

277. The commentary Vaidikäbharana on the TPr (i.2) says that the term samānāksara "simple vowels" actually applies to all vowels except the diphthongs. The commentator refers to the RPr where we have elght samānākșaras, i.e. short and long $/ \mathrm{a} / \mathrm{h} / \mathrm{i} / \mathrm{,} / \mathrm{u} / \mathrm{and}$ $7 \mathrm{r} /$. He says that the designations such as these are for the purpose of using them (upayogãnugunyāt) to formulate rules, and hence for the specific needs of the system in the TPr only nine sounds, i.e. short, long and extra-long $/ \mathrm{a} / \mathrm{h} / \mathrm{i} /$ and $/ \mathrm{u} /$ are called samānākșaras. The term savarna is used with reference to these simple vowels in the TPr (i.3). See:

Vaidikābharana Oriental Library Series, Bibliotheca Sanskrita, No. 33, Mysore, 1906, pp. 10-1.

278. APr, p. 148.

279. Ibid., p. 28.

280. Ibid.

281. Whitney on APr, p. 118.

282. APr (iii. 44, 45, 46), pp. 148-9.

283. APr (ii.31) makārasya sparśe para-sasthānah; Compare: P.8.4.58 (anusvārasya yayi para-savarnah). APr (iii. 30) sasthāne ca; compare: P.8.4.65 (jharo jhari savarne).

284. Thieme (1935a), pp. 85, 95.

285. See: Sec. 4. 7.

286. APr (i.36) samintrókārah, p. 31 .

287. Deshpande (1972), p. 230; also: Sec. 4.9 above.

288. Thieme (1935a), pp. 81-91; his detailed argument is found in Thieme (1937-8), pp. 189-209. Also

V. Venkatarama Sarma (1935), pp. 96 ff.

289. VPr, p. 8.

290. $\operatorname{VPr}($ i. $65-84)$, pp. 10-12. 
291. 'ahavisarjanīyāh kanthha' (71) iti akārasya mātrikasya dvimātrikasya trimātrikasya kanțha-sthānatā uktā tathā 'kanthyā madhyena' (84) iti samãna -karanatā

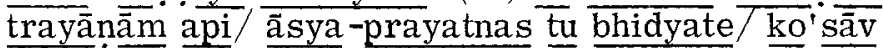

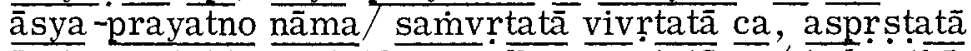

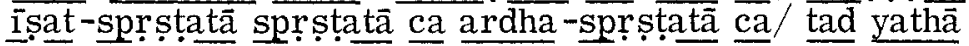

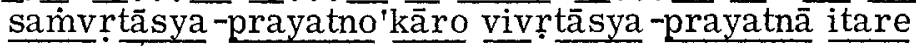
svarăh $\overline{\text { tad }}$ yathā aspristatāsya -prayatnāh svarāh, sprștatāsya -prayatnāh sparśāḥ, tathā íṣat -spṛsțatāsyaprayatnā antahsthāh, ardha -sprọțatā sya -prayatnā ựmāno -nusvāraś ca/ ayam āsya-prayatnah śikșāvidbhir ulstah iha grhyate/ Uvata on $\mathrm{VPr}(\mathrm{W})$, pp. 118 -9. Also: Venkatarama Sarma (1935), pp. 169-70. The VPr (i.11) [dve karane] says that there are two karanas. The word karana is used by the VPr normally to refer to the articulator [ cf. VPr (i. 4), (i. 75-6), (i. 80) ]. However, on this rule, Uvata says that there are two karanas, i.e. samvrta and vivrrta, which probably refers to open and closed positions of the glottis [cf. RPr (13.1-2), TPr (ii.4-5)]. The commentary of Anantabhatta gives the same interpretation, but quotes a verse attributed to Kātyāyana, which speaks of four prayatnas: sprsța "with contact," ișat-sprsțta "with slight contact," samvrta "closed" and vivrta "open" [ see: Vājasaneyi-Prātiśākhya, with the commentaries of Uvața and Anantabhatța, Madras University Sanskrit Series, No. $\underline{5}$, Madras, 1934, p. 9] . Here, Anantabhatta seems to interpret the term karana with the term prayatna. If the vowels and spirants were vivrta "open, "then the VPr would require a rule like P.1.1. $\overline{10}$ (nājjhalau) to prohibit homogeneity of vowels with spirants. The very fact that the VPr does not have such a rule is an indication that vowels and spirants had different efforts. Thus Uvata's comments on the VPr (i.72) seem to be quite appropriate. Anantabhatța, even on the VPr (i. 72), sticks to the view that vowels and spirants are both vivrta "open, " without solving the impending question of their homogeneity.

292. savarnavac ca, VPr (i. 72), p. 11. See: ato'kãrasya mātrikasya samvrtāsyaprayatnasya itarayoś ca vivrtāsya-prayatnayor dvimātrika -trimātrikayọ 
sāvarnyam tulyam na bhavati, tad-artham idam ārabhyate/

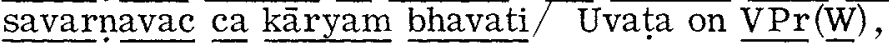
pp. 118-9.

293. Thieme (1935a), pp. 89-90.

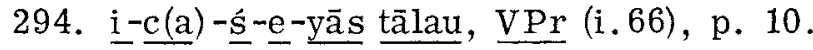

295. tālu-sthānā madhyena, $\operatorname{VPr}$ (i. 79), p. 12.

296. $\underline{u}-v-o-h p(a)-p a \overline{~ o s t h e, ~} \operatorname{VPr}$ (i. 70), p. 11.

297. samāna -sthāna -karañā nāsikyausthyāh

298. See: n. 116 and 117.

299. Thieme (1935a), p. 93.

300. Ibid., p. 92, Fn. 3. Cardona has criticized Thieme's views regarding Pānini's knowledge of sthāna and karana: "The finally accepted analysis of āsya in Bh. ad 1.1 .9 is that it is a taddhita derivative with suffix -ya (5.1.6) like dantya. Therefore $\bar{a} s y a$, analysed as meaning a asye bhavam 'located in the mouth' (Bh. I.61.25), includes a reference to sthāna and, concomitantly, to karana. cf. Bh I.61.25-6 kim punar àsye bhavam, sthānam karanam ca.... Hence I do not think we can state, with Thieme (Panini and the Veda, 94, n. 1), that Pänini did not know the doctrine of sthäna and karana." Cardona (1965a), p. 227, fn. 6. Thieme clearly intends 'articulator' or 'active organ' by the term karana in this context.

301. evam api vyapadeśo na prakalpate -'āsye yeșām tulyo deśa iti / vyapadeśivad -bhāvena bhavisyati/siddhyati/ sūtram tarhi bhidyate yathā-nyāsam evāstu nanu coktam -savarna-saminñāyām bhinna-deśsesv ati-pra sangah, prayatna-sāmānyāt iti/ naișa doșah / na hi laukikam ăsyam/kim tarhi taddhitāntam à àsyam/ āsye bhavamāsyam - 'sarínāvayavād yat'/ kim punar āsye bhavam/ sthānam karanam ca/, $\overline{\mathrm{MB}}, \overline{\mathrm{Vol}}$. I, Sec. I, p. 155.

302. karaṇam iti/ sprșțatādi, jihvāyā agropāgra -madhyamūläni vāT MB-P, Vol. I, Sec. $\overline{\mathrm{I}}, \mathrm{p}$. 155. Viśveśvarasūri $\overline{[\text { VSSN }}, \bar{p} .2 \overline{24]}$ discusses these two interpretations given by Kaiyata, and says that the first, i.e. 
karana $=$ spr ștatādi, is vyavahārābhiprāyam na tu tātvikam "according to the conventional use of the term, and not really true." Then he argues that sprstata "property of being in contact" etc. stands for different kinds of samyogas "conjunctions" and could not be karana "active instrument" in the real sense. They are not "active, " but they are "activities" themselves. The second explanation by Kaiyața, i. e. karana = jihvāyā agropāgra -madhya -mūläni vāa, is the proper interpretation, because the tip of the tongue etc. are the "active instruments" (vyāpāravad).

303. yadi tarhi 'sati bhede kimcit samānam' iti krtvā savarṇasamjuñā bhavisyati/ śakāra -chakārayoh, sakāārathakārayoh, sakāra -thakārayoh savarṇa-saminñā prāpnoti/ eteșām hi sarvam anyat samānam karaña -varjam $\overline{\mathrm{MB}}, \overline{\mathrm{V}} \overline{\mathrm{l}}$. $\overline{\mathrm{I}, \text { Sec. }} \overline{\mathrm{I}}, \mathrm{p}$. 156 . Though Viš́vé́varasūri considers that the term karana primarily refers to tip of the tongue etc., still on the phrase karana -varjam in the Bhāsya, he explains karana as internal efforts. [ābhyantara -prayatnas tu sarām vivrtatvam chādinām tu sprsțatvam iti bhedah, VSSN. p. 230 .]

304. Thieme (1958), p. 43, fn. 24.

305. Ibid., p. 42.

306. mukha-nāsikā-karano' nunāsikah, VPr (i. 75).

307. anusvārasya yayi parasavarnạh (P. 8.4.58).

308. antahsthām antahsthāsv anunā sikām parasasthānām, $\overline{\mathrm{VPr}}$ (iv.9), p. 51 .

309. sparśe para-pañcamam, VPr (iv.11), p. 51.

310. sim savarne dirghah, VPr, (iv. 50), p. 55.

311. anunāsikavaty anunāsikam, VPr (iv. 51), p. 56 .

312. savarne, $\underline{\operatorname{VPr}}$ (iv. 110), p. 64.

313. $\underline{\operatorname{VPr}}(\underline{\mathrm{W}})$, p. 243.

314. rkāra - lkārayor api savarna -dīrghatvam eva bhavati, yady udāharañam chandasi labhyate, Uvața on VPr (i. 43). 
315. ṛhkkau jihvā-mūle, VPr (i.65); llasitā dante, VPr (i.69); dantyā jihvāgra-karanāh, $\operatorname{VPr}(i . \overline{76)}$; jihvā-mūlīyānusvārā hanu-mūlena, VิPr (i. 83), pp. 10-2.

316. svarāś ca lkāra-varjam, VPr(i.87); svarāś ca padāntĩyã bhavanti l $k \bar{a}$ ram varjayitvā, Uvata on VPr (i. 87); also lkāraś cālkāram, VPr (iv.60); Uvața on this rule says: idam sütram kecin na pathanti, vyarthatvāt.

317. kārena ca, VPr (i. 37); a -vyavahitena vyañjanasya, VPr,$\overline{(i .38), p .} 7$.

318. hrasva -grahane dīrgha -plutau pratīyāt, VPr (i.63); prathama -grahane vargam, VPr (i.64), p. 10.

319. rephosmanām savarnā na santi/ vargyo vargyena savarnah/ Sikșā-sūtrāni, p. 15 .

320. See: n. 212 .

321. Ișad-vivrta -karanā ūsmānahah/ vivrta-karanā vā/ Şikșa $\bar{a}$-sütrāni, p. $\overline{2} \overline{1}$.

322. Ibid., p. 5 .

323. yad yad yasya bhavet sthānam karanam vā viśsesanam/ savarnatvena samgrāhya āsya -yatnas tu bhidyate $/ 738 / /$ Varna -ratna -pradīpikā -ŝikșā, Sikșā-samgraha, p. 120.

324. dvimātrasyaika -mātrasya samurtādi -prayatnatah/ bhinnasyāpy astu sāvarnyam tad -artham idam ucyate//, Ibid., pp. $120-1$.

325. pratyayasya savarnatvamin (sakārah) yātīti saakatāyanah/ avikäram ca śākalyo manyate śașaseșu ca

326. Ibid., p. 119.

327. savarne (141), savarne pare vyañjanam dvir na bhavati/

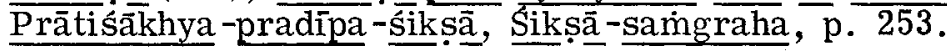

328. Ibid., p. 228.

329. atra rkãroccārañe viśeșah/ tathā ca pratijnā-sūtre "ṛkāra sya tu saỹyuktā saỹyukta syā viś esena sarvvatraivam" / asyārthah $/$ padānta-madhyeșu samyuktāsamyuktasya rvarnasya rekāraḥ syāt/ sarvatra samhitāyām pade ca/

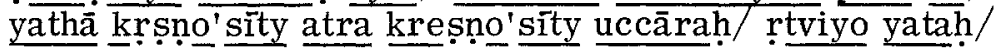


atra retviya ity uccārah/ evam 'ṛlvarnayor mithah sāvarnyam vā̄cyam' iti vārttikena lkārasyāpi le ity uccãrah/k klptam ity atra kleptam ity uccārah Ibid., p. 296 .

330. valhāmasīty atra valehāmasīty uccāro ralayoh sāvarnyāt, Keśavi-śikșâ, Sikșā-samgraha, p. 142. Also:

Venkatarama sarma (1935), p. 441.

331. Kielhorn (1876), p. 197.

332. Though I could not obtain the published edition of the Vyāsa-śikșā, I was fortunate to obtain a microfilm of a manuscript of this text in the Vaidika Samśodhana Mandala, Poona [No. 4564] . In the following notes, I shall augment Luiders with the original Sanskrit quotations from this manuscript.

333. Lüders (1894), p. 5, verse 5 (folio 2): sparśānām pañca pañca syur vargā vargottarasya ca/ tat-prathamādi samjñăh syuh/; verse 10 of Lüders appears to be verse 7 of this Ms.: tulya-rūpam savarnam syāt (folio 3 ); verse 13 of Lüders is verse 9 of the Ms.: bhaved akärah kārordhve halām (ākhyā) (folio 4). Perhaps the numbers in Lüders refer to "rules" rather than to verses.

334. Lïders (1894), p. 9. I have not been able to find a parallel verse in my Ms.

335. Ibid. The number 172 of Lüders is verse 116 of the Ms. : ādy -asțasu savarnordhve dírgham apluta -pūrvakah (folio 39$)$.

336. Lüders (1894), p. 13. The number 269 of Lüders is verse 183 of the Ms.: antahsthodayam angam syāt asavarna-parasya ca (folio $5 \overline{5}$ ).

337. Lüders (1894), p. 16. However, certain verses found in the Ms. of the Vyāsa -śikșā indicate a notion similar to Pānini's. The verses $\overline{78}-\overline{9}$ (folio 26) are as follows: nakāro laparas tasya sasthānam anunāsikam/ sparśottaro makāras tu yavalottara eva ca/ anunāsikam eteșām savarnam pratipadyate $/ 7$ The usage of the term savarna here is quite similar to that in P.8.4.58 (anusvārasya yayi para-savarnah). 
338. āpadyate makāro rephoșmasu pratyayeș anusvāram/ yalavesu parasavarnam, sparsesu cottamāpattim// Nāradìa -śikșā, 2nd Prapāthaka, 4th Kandikā; rephoșmasu parato makāro nusvāratvam $/ .$. yalavesu parasavarnatā, sparśsesu paratah sparśa -vargasadrśottamāpattir makārasya bhavati/ Bhațta Sobhākara's comm., Nāradīya -śikșā, p. 60 .

339. anantyaś ca bhavet pürvo'ntyaś ca parato yadi/tatra madhye yamas tisthet savarnah pürva-varnayoh 7 2nd Prapāthaka, 2nd Kandikì , Nāradiya-śiksā, p. 52.

340. pūrvasya varnasya savarnah sadṛ́ah, Śobhākara's comm., Nāradìna-siksā, p. $\overline{52}$.

341. evam ime na lakșanena yuktā, nāpy ākrțtyā, nāpy upadiștāḥ, MB-D, p. 81 .

342. rephosmanām savarnā na santi / vargyo vargyena

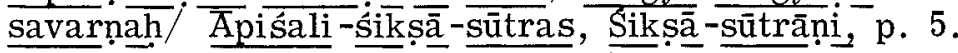

343: spṛsța -karanāh sparśāh/ vivrta -karanāh svarāh ūṣmānaś ca) Ibid., p. 3 .

344. samivrto'karah, Ibid., p. 4.

345. Burnell (1875), p. 22.

346. Ibid., p. 2.

347. siddho varna -samāmnāyah, Kātantra (1.1.1), p. 14. tatra caturda sāāau svarāh, Kātantra (1.1.2), p. 14.

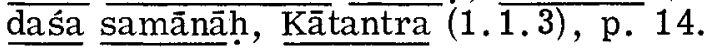

348. tesām dvau dvāv anyonyasya savarnau, Kātantra (1.1.4), p. $\overline{14}$.

349. Ibid., p. 14.

350. samānah savarne dïrghī-bhavati paraś ca lopam, Kātantra $(1.2 .1), \overline{\text { p. } 17}$.

351. ivarno yam asavarne, na ca paro lopyah, Kātantra (1.2. $)$; uvarno vam, Kātantra (1. 2.9); ram rvarnah, Katantra (1.2.10); lam lvarnah, Kätantra (1.2.11), pp. 17-8. 
352. abhyāsasyāsavarne, Kātantra (3.4.56), p. 70.

353. samānād anyo' savarṇah, Bāla -śikșā, p. 4.

354. ram rvarnah, Kātantra (1.2.10); lam lvarnah, 1.2.11; rvarne ar, 1.2 .4 ; lvarne al, $1.2 . \overline{5 ; p p} \cdot \overrightarrow{1} 7 \overrightarrow{-8}$.

355. Kātantra-vyākarana [Eggeling's edn.] , p. 470. Bhāvasena Traividya in his Kātantra-rūpa -mālā -prakriyā (ed. by Jivaram Shastri, published by Hirachand Nemichand Shreshthi, Bombay, Samvat 1952, p. 3) gives rkāra-lkārau ca as rule 5 . His commentary runs as: rkāra-lkārau ca parasparam savarna-samjñau bhavatah.

356. rkāra -lkārayoh savarṇa-samjnãā lokopacārāt siddheti bhāvah, Trilocanadāsa's commentary, quoted by Eggeling, ibid., p. 480.

357. yat tu trilocanadāsenoktam rkāra -1kārayoh samijñā lokopacāratah siddheti tan na loke lkāre rkāra- . vyavahārasyä̀darśanāt/ Laghubhãsya, p. 14.

358. Kātantra-paribhāșā-sūtra -vrrtti of Bhāvamiśra, Paribhāsā

359. sasthäna-kriyam svam, Jainendra (1.1.2), p. 2.

360. sthānam tālvādi, kriyā sprșțatādikā..., samānā sthāne kriyā yasya, sāmarthyāt sthānam api samānam labhyate/ ...sā caturvidhā... sprștatā, issat -sprstatāa viv rtatā, ișad-vivrtatā ceti/ Mahāvrtti on Jainendra -vyākarana, p. $\overline{2}$.

361. anye samivrtam akāram icchanti loke/ śāstra -vyavahāre tu vivrtam / etac cāyuktam, loka -śāstrayor uccārañam praty aviśesāt/ ibid., p. 2. This criticism of Abhayanandin clearly neglects the meta-linguistic purpose of using open /a/ in Pānini's grammar.

362. rephosmanām svā na santi/vargyah sva-vargyena svasamjño bhavati T Mahāvrtti , Jainendra- vyākarana, p. 3 .

363. anudit svasyātmanā' bhāvyo'taparah, Jainendra (1.1.72), p. $\overline{16}$. 
364. yayy anusvārasya parasvam, Jainendra (5.4.132), comp. with anusvārasya yayi parasavarnah (P. 8.4.58). jharo jhari sve, Jainendra (5.4.139) comp. with jharo jhari savarne (P.8.4.65). sve'ko dih, Jainendra (4.3.88), comp. with akah savarne dirghah (p.6.1.101). na padānta -dvitva -vare ya -kha-svānusvāra -dí-carvidhau, Jainendra (1.1. 59), comp. with na padāntadvirvacana-vare -yalopa śvara -savarñānusvāra-dīrghajaś-car-vidhisu (P.1.1.58).

365. "The Jainendra grammar, taken as a whole, is a copy of Pānini pure and simple, and the sole principle on which it was manufactured appears to be that the saving of a half a short vowel affords as much delight as the birth of a son." Kielhorn, "On the Jainendra -Vyākarana," Indian Antiquary, Vol. 10, March 1881, p. 76 .

366. ranto'n uh, Jainendra (1.1.48), uh sthāne prasajyamāna eva ranto bhavati/... r. kāayoh sva-samjjnoktā/tena tavalkārah h ...katham lantatvam? ranta iti lano lakārākārena praśleșa -nirdeśāt pratyāhāra-grahānam/ Mahāvrtti of Abhayanandin, Jainendra-vyākarana, p. 11. Abhayanindin quotes a Vārttika: rkāra-lkārayoh svasamiñā vaktavyā, ibid., p. 3 .

367. jāti -nirdeśaś cāyam, Cāndra-vyākarana, Vol. I, p. 2.

368. utā savargah, Cāndra (1.1.2), Vol. I, p. 10.

369. anusvārasya yayi yam, Cāndra (6.4.151), comp. with anusvarasya yayi para-savarnah (P. 8. 4.58). ako'ki dírghah, Cāndra (5.1.106), comp. with akah savarne dirghah (P.6.1.101). Actually, Bhattoji Diksita says that the Candra rule is better worded than P.6.1.101. [ ako'ki dírgha ity eva suvacam, SK, p. 7.]

370. halo jharām jhari sasthāne lopo vā, Cāndra (6.4.155), comp. with jharo jhari savarne (P.8.4.65). There is, however, a rule where Cāndra uses the term savarna:

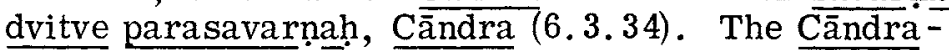
paribhăsā-sūtras contain the maxim: bhāvyamānot savarnān grhñāti, Cānđara -vyākarana, Vol.'II, p. 397. We should note here that the Vrtti on Candragomin's rules, which was declared by Liebich to be an 
autocommentary (svopajña), has been doubted by scholars for not being a work of Candragomin himself. Thus, this is yet an open question. For a discussion of this point, see: "Ist Candragomin der Verfasser der Cāndra-Vṛtti ?, " by $R$. Birwé, Mélanges d'Indianisme à la mémoir de Louis Renou, Publications de l'Institut de Civilisation Indienne, Fascicule 28, Paris, 1968. The same might be said of the Cāndra -paribhāșā-sūtras.

371. sāmānyāśrayanāt dīrgha -plutānunāsikānām grahanạ, Amoghavrtti, Sākațāyana -vyākarana, p. 1.

372. bhāvyo'g, Śākațāyana (1.1.4), p. 2.

373. teyān, Sākatāyana (1.1.3), p. 2.

374. svạ̣ sthānāsyaikye, Śākatāyana (1.1.6), sthānam

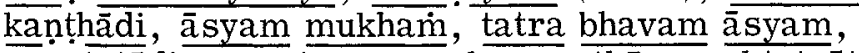
sprșțatādi-prayatna-pañcakam, sthāna syoktatvāt, Amoghavr tti, Sākațayana-vyākaraña, p. 3. Comp. with Patañali' 's interpretation of āsya in P.1.1.9. [See: Sec. 2.4.]

375. samir rtam akārasyeti, Amoghavrtti, ibid., p. 3.

376. a a a i ity akāra udātto'nudāttah svaritaś cānanunāsiko' nunāsikaś ceti sạt/ evam dīrgha-plutāv iti dvādaśa varna-bhedāh parasparasya sve bhavanti evam,

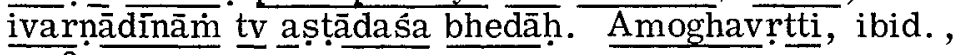
p. 3 .

377. İsad-vivrtam ūsmanām, ibid., p. 3.

378. rephosmanāim sve na bhavanti, ibid., p. 3 .

379. utā svaḥ, Sākațāyana (1.1.2), ibid., p. 2.

380. ukārenetā sahopādīyamāno varnah svasya vargasya samjñā bhavaty ātmanā saha, Ámoghavrtti ibid., p. 2.

381. r ity eva lvarnasya grahanam, ibid., p. 1.

382. tathā ca 'rty akaḥ' (1.1.75) ityādi lkāre'pi siddham bhavati, ibid., p. 1. Also: pp. 15-6, 18 .

383. jari jarah sve vā, Śākațāyana (1.1.133), ibid., p. 23.

384. Nemichandra Shastri (1963), pp. 92 ff. 
385. tulya-sthānāsya -prayatnah svaḥ, Hemacandra (1.1.17).

386. karanam tu jihvā -mūla -madhyāgropāgra -rūpam sthānāsyaprayatna -tulyatve sati nātulyam bhavatīti prọthak noktam, B Brhad-v r $r$ tti, Hema -śa bdānuśāsana, p. 3.

387. issad-vivrtam karanam ūsmanām/ vivrtam karanam svarānām/'üṣmanāị ce'ty anye / ibid., p. 4.

388. akārah samvrta ity anye/ibid., p. 4/

389. pañcako vargah, Hemacandra (1.1.12), and also: varnāvyayāt svarūpe kārah, Hemacandra (7.2.156).

390. samānānām tena dīrghạ, Hemacandra (1.21.) is closer to Kātantra $(1.2 .1), \underline{T P r}(\bar{x} .2), \underline{A P r}$ (iii. 42) and VPr (iv. 50) than to P.6.1.101.

391. ivarnãder asve yavaralam, Hemacandra (1.2 .21). comp. with Käntantra (1.2.8-11).

392. tau mumau vyañjane svau, Hemacandra (1.3.14).

393. anusvārasya yayi para-savarṇah , P. 8.4.58.

394. dhuto dhuți sve vāa Hemacandra (1.3.48).

395. jharo jhari savarne, P. 8. 4.65.

396. ivarnāder asve yavaralam, Hemacandra (1.2.21); avarnasyevarnā dinā edodaral, Hemacandra (1.2.6); rty ār upasargasya, Hemacandra $(\overline{1.2 .9) \text { and } \underline{t} t y}$ āl vāa Hemacandra (1.2.11).

397. ṛkārāpadiștạm kāryam lkārasyāpi, Maxim 71, Nyāyasamgraha $, \overline{\mathrm{PBS}}, \mathrm{p.} 109$.

398. svaḥ sthāna -spṛșțatādy -aikye, Malayagiri (2nd sandhi, 1), p. 5 .

399. sprusțatā, ișat-sprșțatä, vivrtatā, issad-vivrtatā / . . rephaśasasahänām tu sve na santi ${ }^{\circ}$ Svopajña-vrtti, Malayagiri's Sabdānusāsana , p. 5 .

400. Ibid., p. 5 .

401. utā sva-vargasya, Malayagiri (2nd sandhi, 14), p. 8.

402. ik etah, Malayagiri (1st sandhi, 6); r rtạ an, (1st sandhi, 8 ; edādi ecc, (1st sandhi, 9); e-o ên, 
(1st sandhi, 10); Malayagiri's Sabdānusāāana, p. 3.

403. Śākatãyana-vyākarana, p. 1 .

404. yaralavā yañ, Malayagiri (1st sandhi, 17), p. 4.

405. Śākatāyana -vyākaraṇa, p. 1 .

406. ikah asve yañ, Malayagiri (3rd sandhi, 2), p. 10.

407. dírghah sve saparasvarasya, Malayagiri (3rd sandhi, 5), p. 11 .

408. trrtiyasya svah anunäsikah pañcame, Malayagiri (4th sandhi, 8); pratyaye, Malayagiri (4th sandhi, 9); mnām dhuți apadānte, Malayagiri (4th sandhi, 10); p. 17.

409. vyañjanāt yañ-pañcamasya sarūpe vā, Malayagiri (5th sandhi, 4), p. 21.

410. āvat svarghaplu, Mugdhabodha (5), p. 5.

411. ñapo'k samo rna rk $\underline{\text { ca }}$, Mugdhabodha (6), p. 6 .

412. sāmyam tv eka -sthānatvam, Vrttî, Mugdhabodhavyākarana, p. 6 .

413. capoditākānitā rnạh, Mugdhabodha (7), p. 7.

414. saha rne rghah, Mugdhabodha (22), p. 17.

415. Comp. RPr (2nd patala, verse 6), APr (ii.31), APr

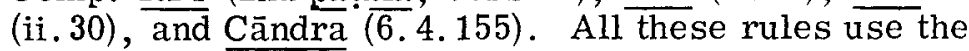
term sasthāna instead of savarna.

416. aiuṛ samānāh, Sārasvata (1), p. 1; hrasva -dīrghapluta-bhedāh savarṇāh, Sārasvata (2), p. 1.

417. varna -grahane savarna -grahanam/ kāra -grahane kevala grahanam/ tapara-karanam tävanmātrārtham/ Särasvatavyākarana, p. 6.

418. ku -cu-tu-tu -pu, ibid., p. 4.

419. a savarne svare pare pūrvekārokārayor iy -uvau vaktavyau, Sārasvata (771), p. 134; savarne dírghah̆ saha, S̄ārasvata (52), p. 9.

420. hasăt jhasasya savarne jhase lopo vācyah, Sãrasvata $\overline{(990)}$, p. 181 . 
421. vargyo vargyena savarnah, qt. in the Vrtti, Sărasvatavyākarana, p. $\overline{7}$.

422. ṛ̣̂varnayoh sāvarnyam vācyam, Sārasvata (63), pp. 10-1.

423. rịnarna -sthānikatvād ralayor api sāvarnyam vācyam/ ... ralayor dalayoś caiva śasayor bavayos tathā/vadanty eșām ca sāvarnyam alamịāravido janāh/ sārasvatavyākarana, pp. 10-1.

424. tulya -sthānāsya -prayatnah savarnah, Sarasvatī-kanthīābharana (1.1.101), Pt. I, p. 27.

425. nājjhalau, Sarasvatī-kanthābharana (1.1.102), ibid, p. 28. No other text has a rule parallel to nājjhalau. However, Krșnadãsa's commentary on the KautsaVyākarana which is identical with the APr = Saunakiya Caturādhyāyikā] interprets the rule naikāraukārayoh sthāna-vidhau, APr (i.41), as a rule prohibiting homogeneity of vowels and consonants. This version of the Kautsa -vyākarana, according to Kṛṣadāsa's commentary, [Vaidika Samśodhana Maṇaḷa, Poona, Ms. E4179, folio 9] has a rule: sasthāna-karanam savarnam. This would make two sounds homogeneous with each other if they share the same point of articulation and internal effort. Krṣnadāsa [ibid., folio 5] holds that vowels and spirants are both vivrta. Thus this creates the same problem that Pänini was faced with. Kṛșnadāsa interprets naikāraukārayoḥ sthānavidhau as: hrasva-dīrghaplutānām svarānām para -sannikarșanāt a i e ai u o au

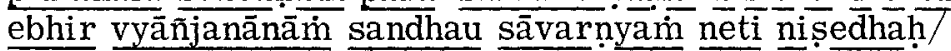
nājjhalāv iti pāninịh] ibid., folio $\overline{5 .}$ This is, however, a very doubtful interpretation.

426. Burnell (1875), pp. $60 \mathrm{ff}$.

427. aãdayo titālísa vannnā, Moggallāna (1.1), p. 1; dasādo sarā, Moggallāna (1.2), p. 1.

428. dve dve savaṇnăa Moggallāna (1.3), p. 2.

429. para -samañnāa payoge, Kaccāyana (1.1.9), p. 12.

430. kva cāsavannạm lutte, Kaccāyana (1.2.3), p. 18.

431. rassa-sarā saka-saka -dīghehi añnamaññam savaṇnā 
nāma sarūpā ti pi vuccanti/ Kaccāna -vannnanāā, Kaccāyanavyākarana, p. $1 \overline{3}$.

432. Thieme (1935a), pp. 92-3; Nemichandra Shastri (1963), pp. 69-70; Burnell (1875), p. 24.

433. Burnell (1875), p. 27.

434. omkāram prcchämah ko dhätuh? kim prätipadikam? kim nāmākhyātam? kim lìngam? kim vacanam? kā vibhaktih̆ ? kah pratyayah? kah svarah upasargo nipātah ? kim vai vyä̀karanam? ko vikārah? kativarnah? katy -aksarah? kati-padah? kah samiogohah? kim sthānānupradāna -karanam? śiksukāh kim uccārayanti ? kim chandah? ko varnah? iti pūrve praśnāh, GopathaBrāhmaṇa, (i. $\overline{24})$.

435. śikṣāin vyākyāsyāmah/varnāh svarah/mātrā balam/ sāma santānah̆ ity uktaḥ śikșādhyāyah TaittiriyaUpanisad (vii. $1 . \overline{2}$ ).

436. Weber, Indische Studien, Vol. iv, p. 75 .

437. Burnell (1875), pp. $28 \mathrm{ff}$.

438. Ibid., pp. $2 \mathrm{ff}$.

439. asandigdham parābhāvāt savarne'n taparam hy ur r r.t,

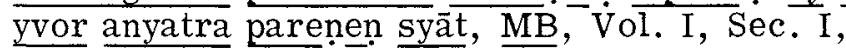
pp. $97-100$.

440. kim punar varnotsattāv ivāyam nakāro dvir anubadhyate? etaj jñāpayaty āāryah: bhavaty eșā paribhāșāvyākhyānato viśesa-pratipattir nà hi sandehād alaksanamiti/ MB, Vol. I, Sec. I, p. 100 .

441. anuditsavarnam parihāya pūrvenān-grahanam, parenen grahanam iti vyākhyāsyāmah/ MB , Vol. I, Sec. I, p. 100.

442. On P.1.1.1 (vrddhir ād-aic), Kātyāyana explains the purpose of adding the marker $/ \mathrm{T} /$ to $/ \overline{\mathrm{a}} /$, by saying that $/ \bar{a} /$ is a non $-/ \mathrm{a}-\mathrm{N} /$ sound and accents etc. are distinctive. Thus, $/ \bar{a} /$ would not cover homogeneous varieties differing in accent, unless it is marked with $/ \mathrm{T} /$. [ākārasya tapara-karanam savarnārtham bhedakatvät svarasya, Vārttika on P.1. 1.1, MB, Vol. I, Sec. I, p. 113.] He has no such doubts about /ai -C/ sounds 
in the same rule. On the other hand, he positively fears that /e-C/ sounds might stand for short/e/ etc., as well as for extra-long varieties. [atapara eca igghrasvādeśe, and ekādeśe dirrgha -grahanam, Vārttikas, MB, Vol. I, Sec. I, pp. 78-9.] This clearly indicates that he accepts $/ \mathrm{a}-\mathrm{N} / \mathrm{in}$ P.1.1.69 to be formed with /N/ in the Siva-sūtra: 1(a)-N. Also see: Deshpande (1972), pp. $\overline{226}, \overline{249}-5 \overline{1}$.

443. Kunhan Raja (1957), p. 70-1.

444. Ibid., p. 71 .

445. Ibid., p. 73.

446. Ibid., pp. 73-4.

447. Ibid., p. 80 , Fn. 20.

448. Ibid., p. 80 , Fn. 19.

449. edaitoh kantha -tālu/ odautoh kanthostham/ . . vivrrtam

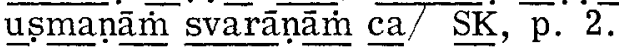

450. siddham enaah sasthānatvāt, Vārttika on P.1.1.48, MB, Vol. I, Sec. I, p. 262.

451. aicoś cottara -bhūyastvăt, Vārttika on P.1.1.48, MB, Vol. I, Sec. I, p. 262 .

452. Sandhyaksaresu vivṛtatvāt, Vārttika, yad atrāvarnạm vivrtataram tad anyasmād avarnāt/ ye'pivarnovarne vivrtatare te anyābhyām ivarnovarnnābhayām $\mathrm{MB}$, Vol. I, Sec. I, p. 84 .

453. praślistāvarnāv etau (eñau), vivrtatarāvarnāv etau (aicau) / etayor eva tarhi mithas savarna-saimjñā prāpnoti/

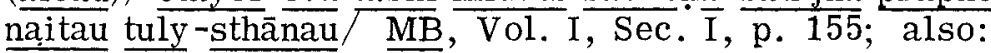
imāv aicau samāhāra -varnau -mātrāvarna sya mātrevarnovarnayoh/ $\overline{\mathrm{MB}}$, Vol. I, Sec. $\overline{\mathrm{I}, \mathrm{p}} .78$ and Vol. III, p. 426. Siddheshwar Varma is off the point in describing Patañjali's views: "Here an objector states the opinion, attributed to saakatāyana, that both the elements of the diphthongs /ai/ and /au/were equal, being one mora each.... Patañjali, however, does not accept this opinion; he seems to follow the opinion expressed by the Ṛg-Prāt. and the Pāniniya-sikșā, 
that the second element of the diphthongs /ai/ and /au/ was longer." Varma (1929), pp. 180-1. Contrast: bhāsyakāro vārttikakāram paryanuyunikte/ 'aicoś cottarabhūyastvād' iti vadatā vārttikakārena sama -pravibhāgatvam nesțam iti bhāvah, MB-P, Vol. III, p. 427, and samapravibhăga -pakșa eva bhägavato bhāsyakārasya sammata iti bodhyam, MB- $-\underline{\text { P-U }}$, Vo. III, p. 427 , on P.8.2.106.

454. i-c(a) -ś-e-yās talau (i. 66), u -v-o-hp(a) -pāh osthe (i. 70), aikāraukā rayoh kanthyā pūrvā mātrā, tālvosthayor uttarā (i. 73), V $\overline{\mathrm{Pr}}, \overline{\text { p. }} 3$; akārārdham aikāraukārayor ădih (ii. 26), ikāro'dhyardhah pūrvasya sesạ (ii. 28), ukäras tūttarasya (ii.29), TPr, pp. 65-6; sandhyaksarāni samsprșta-varnāny eka -varnavad vrttih (i. 40), naikāraukārayoh sthāna -vidhau (i. 4i), APr, pp. 34-5; sandhyāni sandhyakșarāṇy āhur eke dvisthānataiteșu tathobhayesu sandhyeș akāro' rdham ikāra uttaram yujor ukāra iti śākatāyanah/mātrā-sàmsargād avare prithak -śrutī hrasvänusvāra -vyatișangavat pare $\mathrm{RPr}$, 13th patala, verses 15-6, pp. 56-7; sandhyam dvivarnam, (3.4.5), Rk-tantra, p. 22. The word dvivarna here refers to $/ \mathrm{a} i /$ and $/ \mathrm{au} /$, and clearly refers to their composition in contrast to $/ \mathrm{e} /$ and $/ \mathrm{o} /$.

455. e ai tu kanththa -tālavyāv o au kanthostthajau smrtau/ ârdha-mätrā tu kanthyā syād ekā raikārayor bhavet/ okāraukārayor mātrā tayor vivrta samvrtam/ Pāninina ŝikșā, verses 18-9. These are very unclear lines. Even Weber has different, but much more corrupt lines ["Die Pāniniya-śiksāā," Indische Studien, Vol. IV, Berlin, p858, pp. 353-4] . Also: svarānām uṣmanām caiva vivrtam karanam smrtam/ tebhyo pi vivṝāv eñau tābhyām aicau tathaiva ca Pāninina -śikșā, verse 21 , p. 386. The päninĩya-siks the same thing to say, see: Siksā-sütras, pp. 11, 12, $20-1$.

456. Deshpande (1972), pp. 221-2, 225, 236, 238.

457. Ibid., pp. 213-4.

458. tapara -karanami dïrghe'pi sthānini hrasva eva yathā syāt-

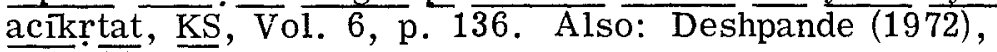
pp. $2 \overline{36}-7$. 
459. Deshpande (1972), pp. 236-7, 250-1.

460. Patañjali in his Mahābhāsya on the Śiva -sūtra 1(a) -N seems to suggest that by P.1.1.69 $\overline{\mathrm{y} /}, \overline{\mathrm{v} / \mathrm{a}} \mathrm{a} / \mathrm{l} / \mathrm{stand}$ for $/ \tilde{y} /, / \tilde{v} /$ and $/ \tilde{I} /$, and that the sequences $/ \tilde{y} y /$ etc. are eligible for the designation samyoga "cluster." MB, Vol. I, Sec. I, p. 86. Here he does not bring up the question of $/ \tilde{y} /, / \tilde{v} /$ and $/ \tilde{1} /$ being "non-effected" for P.1.1.7 (halo'nantarāh samyogah), which is quite a legitimate question.

461. dvirvacane parasavarnatvam, Vārttika on P. 8.2.6, dvirvacane parasavarnatvam siddham vaktavyam/ saỹyantā, sa ṽvatsarah, yallokam, tâllokam iti parasavarnasyāsiddhatvăt yara iti dvirvacanam na prāpnoti MB, Vol. III, p. 373 .

462. [A] atha kimartham antahsthānām ansūpadesạ kriyate/

[B] iha saỹyantā, sa ṽvatsarah, yallokam, tanlokam iti parasavarṇasyāsiddhatvā d anusvārasyaiva dvirvacanam/tatra parasya parasavarne krte tasya yay-grahanena grahanāt pūrvasyāpi parasavarno yathā syāt

[C] naitad asti prayojanam/vakșaty etat-dvirvacane parasavarnatvam siddham vaktavyam -iti, yavatā siddhatvam ucyate parasavarna eva tāvad bhavati/

[D] parasavarne tarhi krte tasya yar-grahanena grahanād dvirvacanam yathā syāt

[E] mā bhūd dvirvacanam/

[F] nanu ca bhedo bhavati -sati dvirvacane triyakāram, asati dvirvacane dviyakāram/

[G] $\overline{\text { nāsti }}$ bhedah, satyapi dvirvacane dviyakāram eva/ katham/ 'halo yamām yami lopah ity evam ekasya lopena bhavitavyam/

[H] evam api bhedah/sati dvirvacane kadācid dviyakāram, kadācit triyakāram/ a sati dviyakāram eva/ sa eșa katham bhedo na syăt? yadi nityo lopa syăt vibhāsā ca sa lopah̆/

[ I ] yathā ibhedas tathāistu/

$[\mathrm{J}]$ anuvartate vibhẩsā śa saro' ci yad vārayaty ayam 
dvitvam/ (Śloka -vārttika)/ yad ayam 'śaro'ci' iti dvirvacana -pratiședham śāsti, taj jñāpayaty acăryah-anuvartate vibhāseti/ katham krttvā jñāpakam? "nitye hi tasya lope pratis sedhārtho na kaścit syāt" (śloka -vārttika)/ yadi nityo lopah syāt, pratisedha -vacanam anarthakam syāt/ a stv atra dvirvacanam, "jharo jhari savarne" iti lopo bhavisyati/ paśyati tv ācāryaḥ-vibhā sā sa lopahiti, tato dvirvacana -pratisedham sāsti

[K] naitad asti jñāpakam/... tasmān nitye'pi lope' vaśyam sa pratisedho vaktavyah

[L] tad etad atyanta - sandigdham ācāryānām vartatevibhāșā 'nuvartate na veti/ $\mathrm{MB}$, Vol. I, Sec. I, pp. $96-7$.

463. halo yamām yami lopah ity ekasyātra lopo bhavisyati/ vibhăsā sa lopah $\overline{\mathrm{MB}}$, Vol. I, Sec. I, p. 99.

464. MB, Vol. I, Sec. I, pp. 89-91.

465. KS, Vol. I, p. 52.

466. Bhattoji Dikșita says in his SKB that, since, according to Patanjali, features like nasality are non-distinctive, $/ \mathrm{y} /, / \mathrm{v} /$ and $/ 1 /$ would naturally stand for $/ \tilde{\mathrm{y}} /, / \tilde{\mathrm{v}} /$ and $/ \mathrm{I} /$, and hence it would be proper to have only $/ \mathrm{a}-\mathrm{C} / \mathrm{in}$ P.1.1.69. However, Pānini uses /a $-\mathrm{N} /$, including semivowels, in P.1.1.69, in order to indicate that features like nasality are distinctive and that, without a rule, $/ \mathrm{y} /, / \mathrm{v} /$ and $/ \mathrm{l} /$ cannot stand for $/ \tilde{\mathrm{y}} /, / \tilde{\mathrm{v}} /$ and $/ \tilde{\mathrm{l}} /$. yady api gunānām abhedakatvenaiva sānunāsika -yavalanāmin dvitva-siddher grahanaka-śāstre'j-grahanam evocitami na tv an-grahanam, tathāpi gunāh bhedakāḥ i ity api paksam jñāpayitum an-grahanam SKB,$\overline{\text { p. } 61 . ~ F o r ~ t h e ~}$ controver sy bhedakā guñăh and abhedakā gunāh, see: Sec. 6.5-6.13, and Deshpande (1972), pp. $2 \overrightarrow{26}-30$.

467. ācāryopadeśa -pāramparyāt tu jūāyate-'anuvartate vibhāșā' iti/ ta smāt trivyañjana-sam̉yoga-śravañāya 'anudid̄' iti nakārena pratyāhāra kr krto na cakāreneti sthitam MB-P, Vol. I, Sec. I, p. 97.

468. jñāpakāntaram grāhaka-sūtrasthān-grahanam/ tad dhi saỹyantety ādau yādīnām sānunāsikānām dvitvārthàm/ 
lopasya nityatve tu vyartham eva syāt/ BSR, p. 149.

469. an-grahanāj jñāpakād ity api kaścit/ tat tu vārttikakrrtān-grahana-pratyākhyānān noktam $T$ MB $\overline{\mathrm{M}}-\underline{\mathrm{P}}-\underline{\mathrm{U}}$, $\overrightarrow{\mathrm{V}} \mathrm{ol}$. I, Sec. $\overline{\mathrm{I}}$, p. 97.

470. See: n. 461.

471. savarna-savargiya-parah (na dvih) (xiv.23), TPr, p. 307; sasthäne ca (iii.30), APr, p. 142; savarne (iv.110), VPr, p. 62 . These rules would not allow doubling of $\overline{\bar{y}} /$ in forms like saỹyantā.

472. George Cardona does refer to the commentators' question as to why Pānini did not use / a $-\mathrm{C} /$ instead of $/ \mathrm{a}-\mathrm{N} /$ in P.1.1.69, and says: "The answer is, of course, that the semi-vowels $/ y /$, etc. given in the siva-sutras should denote also their nasal counter-parts $/$ may/ etc." Cardona (1969), p. 35. On p. 21 he discusses the rules involving semi-vowels. In (1965a, pp. 229-30), he discusses how it is necessary to have $/ \mathrm{y} /, / \mathrm{v} /$ and $/ 1 /$ homogeneous with $/ \tilde{y} /, / \bar{v} /$ and $/ \tilde{I}$. However, no scholar has so far answered the question as to why $/ y /$, $/ \mathrm{v} /$ and $/ \mathrm{l} /$ are needed to stand for $/ \tilde{\mathrm{y}} /, / \tilde{\mathrm{v}} /$ and $/ \tilde{\mathrm{I}} /$. 


\section{BIBLIOGRAPHY AND ABBREVIATIONS}

\section{PRIMARY SOURCES}

APr Atharvaveda-prātiśākhya or Śaunakīyā Caturādhyāyikā, ed. and tr. with notes by W. D. Whitney, New Haven, 1862.

Bharata-bhāṣyam, by Nānya-bhūpāla, Pt. I., Adhyāyas 1-5, Indirä -kalà -samgita -viśva -vidyālaya -grantha-mālā, $\overline{\text { No. 1. }}$, Khairagarh, Madhya Pradesh, India, $\overline{1961 .}$

Brhhat-paribhāșā-vrttti by Sīradeva, see: PBS.

BSR Brhacchabda-ratna by Hari Dikșita, on the PM, see: PM.

BSS Brhacchabdendu-śekhara by Nãgeśabhatța, in three vols., Sarasvati Bhavana Granthamala, No. 87, ed. by Sitaram Sastri, Banaras, 1960.

Cāndra -vyākarana, with the Svopajña -vrttî, by Candragomin, two vols, ed. by K. C. Chatterji, Deccan College Publication, Poona, 1953, 1961.

Dhātu-pradīpa, by Maitreyarakșita, Savitārāya-smrtîsamraksana-grantha-mālā, No. 2., ed. by Srish Chandra Chakravarti, Rajshahi, Bengal, 1919.

Hemacandra -vyākarana -nyāya -samgraha by Hemaham sagani, see: PBS.

Hema -śabdānusāāsana, with the auto-commentary Bryhadvrrtti (Svopajña-tattva -prakāsikā), pt. I, ed. by Candrasāgarasūuri, Ujjain, (Vikrama) 2007.

Jainendra -vyākarana by Devanandin, with the Mahāvrtti by Abhayanandiñ, Bhāratīya Jñānapitha, Banaras, 1956.

Kaccāyana -yākarana, critically edited, translated and annotated by L. N. Tiwari and Birbal Sharma, Tara Publications, Banaras, 1962. 
Kātantra-paribhāșā-sūtra -vrttti by Bhāvamiśra, see: PBS.

Kātantra-vyākaraña by Śarvavarman: Das Kātantra, Zur

Einführung in die indische einheimische Sprachwissenschaft I, by Bruno Liebich, Heidelberg, 1919. [Page references are given to this edition, unless otherwise indicated.]

Kātantra-vyākarana by Sarvavarman, with the Vrtti by Durgasimha, ed. by J. Eggeling, Bibliotheca Indica, Calcutta, 1874-8.

KM Kārikāvalī-Muktāvalī by Viśvanātha Tarkapañcānana Bhatțācārya, with five commentaries, Sri Balamanorama Series 6, Madras, 1923.

KS Kāśsikā -vrttti by Vãmana and Jayāditya, with the commentaries Nyāsa by Jinendrabuddhi, and Padamañjarĩ by Haradatta, six vols., Prācya Bharati Series 2, Tara Publications, Banaras, 1965-7.

$\underline{\mathrm{KS}} \underline{-\mathrm{N}} \underline{\text { Nyāsa }}$ by Jinendrabuddhi on $\underline{\mathrm{KS}}$, see: KS.

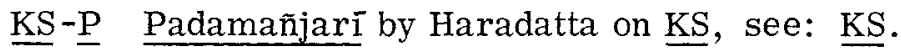

Laghubhāṣya, Sarasvatī-krta -vyākarana -sūtra-vyākhyānam, by Raghunātha Nāgara, Kṣemarāja Kṛ̣̣nadāsa (Publ.), Venkateśvara Press, Bombay, 1900.

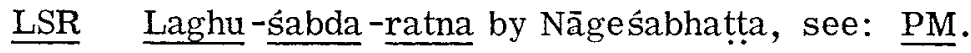

LSS Laghu-śabdendu-śekhara by Nāgeśabhatța, with six commentaries, Rajasthan Sanskrit College Series 14, Banaras, 1936.

MB Vyākarana -Mahābhāșa by Patañjali, with the commentaries Pradipa by Kaiyața, and Uddyota by Nāgesabhatța, three vols., published by Motilal Banarasidass, Delhi, 1967.

MB-D Dipikā [ or Tikīa] by Bhartṛhari on MB, ed. by Abhyankar and Limaye, Bhandarkar Oriental Research Institute, Post Graduate and Research Department Series 8 , Poona, 1970. The same text is edited under the title Mahābhāsya -țikā by V. Swaminathan, Pt. I, Hindu -Vishvavidyālayiya -Nepāla -Rājya -Samskrta Granthamālā, 11, Banaras, 1965. This is occasionally quoted for better readings. 
MB-P Pradipa by Kaiyața on MB, see: MB.

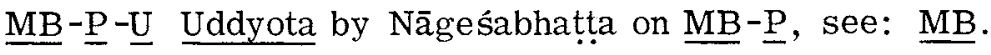

Moggalāna -vyākarana, ed. by Bhadanta Ananda Kausalyāyana, Vishveshvarananda Inst. Publ. 305, Hoshiarpur, 1965.

MPV Mahābhāṣya-Pradīpa -Vyākhyānāni, "Commentaires sur le Mahābhāsya de Patañjali et le Pradipa de Kaiyata," Adhyāya $1 \underline{\mathrm{P} a \overline{\mathrm{d}} \mathrm{a}} 1 \underline{1}$ Ahnika $1-\underline{4}$, édition par M. S. Narasimhacharya, Publications de l'Institut Français d'Indologie, No. 51, 1., Pondichéry, 1973.

MS Mīmāmsā-sūtras by Jaimini, with the Bhäsya by Sabara, the Tantra-vārttika and Tup ttikā by Kumārila, six vols., A Anandāśrama Sanskrit Series 97, Poona, 1929. Third ed. of the pt. I, vol. I, in $1 \overline{953}$.

Mugdhabodha -vyākarana by Bopadeva, with commentaries by Durgā dāsa Vìđyāyāgî́sa and Śrīrāma Tarkavāgīśa, ed. and publ. by Jỉbānanda Vidyāsāgara, Calcutta, 1902.

Nāradiya-śikșā (sāmavedīyā), with the commentary by Bhatța Şobhākara, published by Śri Pĩtāmbara-pittha samiskrta-parișad, Datia, Madhya Pradesh, 1964.

P Pāninini - $\underline{\text { suttra. }}$

Pānininiya -śikșā (Die Pāninīya -śikșā), Rk recensions, ed. and tr. into German, by Albrecht

Weber, Indische Studien, band IV, Berlin, 1858.

Paribhāșā-bhāskara, by Haribhāskara Agnihotrin, see: PBS.

Paribhāșā -sūcana by Vyādi, see: PBS.

Paribhāṣā-vṛtti by Nilakanththa Dikșita, see: PBS.

PBS Paribhāșā-samgraha [A collection of paribhāsā texts from various systems of Sanskrit grammar], ed. by K. V. Abhyankar, Bhandarkar Oriental Research Institute, Post Graduate and Research Department Series, Poona, 1968.

PM Praudha-manoramā by Bhattoji Dikșita, with the commentaries Brrhacchabda -ratna by Hari Dikșita and Laghu-śabda -ratna by Nàgeśabhatta, up to the Avyayibhāva section, Nepal Rajya Hindu 
Viśvavidyālaya Series 3, Banaras, 1964.

Prakriyā -kaumudī, by Rāmacandra, with Prasāda commentary by Vitțhala, ed. by K. P. Trivedi, Bombay Sanskrit and Prakrit Series, LXXVIII (Pt. I), LXXXII (Pt. II), $\overline{192} 5$ and $193 \overline{1 .}$

Prakriyā -sarvasva, by Nārāyanabhaț̣a, Pts. I, II, III, IV, Trivendrum Sanskrit Series, Nos. 106, 139, 153, and 174; Years 1931, 1938,1948 and 1958.

Pratijñā -sūtra, ed. and tr. into German by Albrecht Weber, Abh. d. Kön. Ak. der. Wiss. zu Berlin, 1871.

PS Paribhāsenduśekhara by Nãgeśabhațta, with the commentary Tattvādar śa by M. Vasudeva Shastri Abhyankar, ed. by K. V. Abhyankar, Revised edn. Bhandarkar Oriental Research Institute, Poona, 1962.

Puspa -sūtra, Das, mit Einleitung und Übersetzung, heraus gegeben von Richard Simon, Abhandlungen der Philosophisch-Philologischen Klasse der Köngl. Bayerischen Akademie der Wissenschaften, 23, München, 1904-9.

Rk-tantra [A Prātisākhỳa of the Sāmaveda], ed. by Surya Kanta, Lahore, 1939, reprinted by Meherchand Lachhmandas, Delhi, 1971.

RPr Rgveda-prātis̄ākhya, Pt. I, (Text only), ed. by Mangal Deva Shastri, Banaras, 1959.

Rūpāvatāra, by Dharmakīrti, ed. by M. Rangacharya, published by G. A. Natesan and Co., Madras, Pt. I., (no date given); Pt. II., Bangalore, 1927.

Śabdānuśāsana by Acārya Malayagiri, with his autocommentary Vrtti, ed. by Pt. Becharda J. Doshi, Lalbhai Dalpatbhai Series No. 13, Ahmedabad, 1967.

Saiśiriya-śiksā, ed. by Tarapada Chowdhury, Journal of Vedic Studies, ed. by Raghu Vira, Vol. II., No. II. , Lahore, 1935 .

Śākatāyana -vyākarana, with the auto-commentary Amogha-vrtti, Murtidevi Jaina Granthamala, Sanskrit Series 39, Bhāratĩya Jñānapitha, Banaras, 1971. [Page references 
are given to this edition. ]

Sākațāyana -vyākarana, with the commentary Prakriyāsamgraha by Âbhayacandrasūri, edited by Gustav Oppert, Madras, 1893.

Sāma-tantra by Audavraji, [A Prātiśākhya of the Sāmaveda], with an anonymous Bhāsya, ed. by Ramnath Diksița, Vedic Research Committee, Banaras Hindu University, Banaras, 1961.

Sārasvata -vyākaranam, vṛtti-trayātmakam, by Anubhūtisvarūpacārya, ed. by Narayana Rama Acharya, Nirnayasagara Press, 7th edn., Bombay, 1952.

Sarasvatī-kanthābharana by Bhojadeva, with the commentary Hrudayahārinī by Nārayaña Daṇuanātha, Pt. I. , Trivendrum Sanskrit Series CXVII, Trivendrum, 1935.

Śikṣā-samgraha, a collection of various śikṣās, Banaras Sanskrit Series, Banaras, 1893.

Śikșā-sūtrāṇi, Apisali -Pāṇini-Candragomi-viracitāni, ed. by Yudhisthir Mimamsaka, Ajmer, 2024 Samvat.

SK Siddhānta-kaumudi by Bhatțoji Dikșita, 11th edn., Nirnayasagara Press, Bombay, 1938.

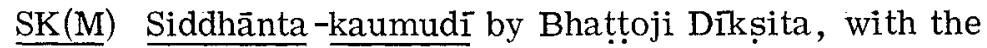
commentaries Bālamanoramā by Vāsudeva Dikșita, and Tattvabodhinī by Jñānendra Sarasvatī, ed. by Giridhar Sarma and Parameshvaranand, publ. by Motilal Banarasidass, Delhi, 1960.

SKB Śabda-kaustubha by Bhatțoji Dikșita, Chowkhamba Sanskrit Series 2, Vol. I, Fasc. I to IV, ed. by Nene and Puntamkar, Banaras, 1933.

TPr Taittitìya-prātisaākhya, with the commentary Tribhāsyaratna, ed. and tr. with notes, by W. D. Whitney, New Haven, 1871.

TS Tarka-samgraha by Annambhatța, with the autocommentary Dipika and the commentary Nyãya bodhini by Govardhana, ed. by Athalye and Bodas, second edn., second impression, Bombay Sanskrit Series LV, Poona, 1963. 
VP Vākya-padiya, edited with appendices, by Abhyankar and Limaye, University of Poona Sanskrit and Prakrit Series, Poona, 1965.

VPr Vājasaneyi -prātišākhya, ed. and tr. by Indu Rastogi, Kashi Sanskrit Series 179, Banaras, 1967. [Page nos. refer to this edn.]

$\underline{\operatorname{VPr}}(\mathrm{W})$ Vājasaneyi-prātiśākhya, ed. and tr. into German, with notes, by Albrecht Weber, Indische Studien, Beiträge für die Kunde des Indischen Alterthums, bd. IV, Berlin, 1858.

VSSN Vyākarana-siddhānta-sudhānidhi, by Viśveśvarasūri, ed. by Dhàdhi Ram Sarma, Chowkhamba Sanskrit Series, Banaras, 1914.

Yājñavalkya -śikșā (Yajurvedīyā), with a Hindi commentary by Brahmamuni, Arya Sahitya Mandal, Ajmer, 1967.

\section{SECONDARY LITERATURE}

Abhyankar, K. V. (1969)

Patañjali's Vyākaraṇa-mahābhāșya, Āhnika I-II, ed. and $t r$. with notes, Sanskrit Vidyā Parisà̄ sthā, Vasudeva Shastri Abhyankar Publication Series 15, Poona, 1969 .

Aklujkar, A. N. (1970)

The Philosophy of Bhartrhari's Trikāndī, a doctoral dissertation, the Dept. of Sanskrit and Indian Studies, Harvard University, Feb. 1970.

Allen, W. S. (1953)

Phonetics in Ancient India, London Oriental Series 1, Oxford University Press, 1953.

Bare, James (1975)

Phonetics and Phonology in Pānini, a doctoral dissertation, Dept. of Linguistics, University of Michigan, Ann Arbor, 1975.

Belvalkar, S. K. (1915)

Systems of Sanskrit Grammar, Poona, 1915. 
Biardeau, M. (1964)

Théorie de la Connaissance et Philosophie de la Parole dans le Brahmanisme classique, Mouton and Co., Paris, 1964.

Böhtlingk, Otto (1887)

Päṇini's Grammatik, Leipzig, 1887.

Breloer, B. (1929)

"Studie zu Pānini," Zeitschrift für Indologie und

Iranistik, Herausgegeben in Auftrage der Deutschen

Morgenländischen Gessellschaft, Leipzig, Bd. 7, Heft 1, pp. 114-35, 1929.

$---(1935)$

"Die 14 Pratyāhāra-sūtras des Pānini," Zetischrift für Indologie und Iranistik, Bd. 10, Heft $\overline{2 \text {, Leipzig, }}$ pp. $\overline{134-91,} 1 \overline{935}$.

Brough, John (1951)

"Theories of General Linguistics in the Sanskrit Grammarians," Transactions of the Philological Society, Cambridge, 1951.

Burnell, A. C. (1875)

On the Aindra School of Sanskrit Grammarians, Mangalore, 1875.

Cardona, G. (1965a)

"On Pānini's Morphophonemic Principles," Language,

Vol. 41. 1965.

$----(1965 b)$

"On Translating and Formalizing Pāninian Rules," Journal of the Oriental Institute, Baroda, Vol. XIV, Nos. 3-4, 1965 .

$---(1968)$

"Review of the Sphota-nirnaya by S. D. Joshi," Journal of the Oriental Institute, Baroda, Vo. XVII, 1968.

$----(1969)$

"Studies in Indian Grammarians I, the Method of Description Reflected in the Siva-sūtras, " Transactions of the American Philosophical Society, New Series, 
Vol. 59, Pt. I, Philadelphia, 1969.

Chatterjee, Kshitis Chandra (1934)

"The Siva-sütras," Journal of the Dept. of Letters,

Vol. XXIV, University of Calcutta, Calcutta, 1934.

$----(1948)$

Technical Terms and Technique of Sanskrit Grammar, University of Calcutta, Calcutta, 1948, revised edn. by Gaurinath Shastri, 1964.

Chattopadhyaya, K. C. (1974)

'Did Pānini Envisage 'A' as a Close (samvrta)

Vowe1 ?" Charudeva Shastri Felicitation Volume, Delhi, 1974.

Chaturvedi, S. P. (1933)

"Homogeneity of Letters in the Pāninian System - A

Critical Estimate of the Views Held by Different

Commentators," Proceedings and Transactions of the Seventh All India Oriental Conference, Baroda, 1933 .

Citrācārya, Jagadīśa (1969)

"Śikșā-sāistram," (in Sanskrit), Bālārka -vedamandīasya prathamam pusppam, Bahrāich, U. P. , India, 1969.

Deshpande, Madhav (1972)

"Pāninian Procedure of Taparakarana: A Historical Investigation," Zeitschrift für vergleichende

Sprachforschung, Band 86, Heft 2, Göttingen, 1972.

----(Forthcoming)

"New Material on the Kautsa -vyākarana, " appearing in the Journal of the Oriental Institute, Baroda (1975 ?).

----(Forthcoming)

"Dhonetics of Short /a/ in Sanskrit," appearing in the Indo-Iranian Journal, 1975.

----(Forthcoming)

"Phonetics of /v/ in Pānini," appearing in the Annals of the Bhandarkar Oriental Research Institute, Poona (1975?). 
---(Forthcoming)

"The Scope of Homogeneous-Representation in Pāṇini," appearing in the Silver Jubilee Volume of the Annals of Oriental Research, University of Madras, Madras.

Devasthali, G. V. (1969)

Sãrasiddhāntakaumudī of Varadarāja Bhatța, ed. and tr. with notes, Publications of the Centre of Advanced Studies in Sanskrit, University of Poona, Poona, 1969.

Ghatage, A. M. (1972)

"A Sample Entry in a Historical Sanskrit Dictionary," Indian Linguistics, Vol. 33, No. 2, Poorla, 1972.

Goldstücker, Theodor (1860)

Pānini: His Place in Sanskrit Literature etc. , London,

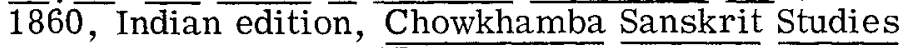
XLVIII, Banaras, 1965.

Joshi, S. D. (1967)

The Sphota-nirnaya of Kaundabhatța, ed. and tr. with notes, Publications of the Centre of Advanced Studies in Sanskrit, Class C, No. 2, University of Poona, Poona, 1967.

---(1969) [In collaboration with J. A. F. Roodbergen] Patañjali's Vyākarana -mahābhāsya, Avyavỉohāvatatpurușāhnika, ed. and tr. with notes, Publications of the Centre of Advanced Studies in Sanskrit, Class C, No. 5, University of Poona, Poona, 1969.

Katre, S. L. (1938)

"Kautsa-vyākarana:A Detailed Notice; Recovery of Kautsa's Authorship," New Indian Antiquary, Vol. I, Bombay, 1938.

Kielhorn, Franz (1876a)

Kātyāyana and Patañjali, their Relation to each other and to Pānini, $\overline{\text { Bombay, }} 1 \overline{876,}$ 2nd edn., Banaras, 1963.

$---(1876 b)$

"Remarks on the Sikșās," The Indian Antiquary, Vol.

5, Bombay, 1876.

$---(1887)$

"Notes on the Mahābhāsya, No. 7, Some Devices of 
Indian Grammarians," The Indian Antiquary, Vol. 16, Bombay, 1887.

$----(1891)$

"Die Colebrooke'schen Pänini-Handschriften der Königlichen Bibliothek zu Göttingen," Nachrichten von der Königlichen Gesellschaft der Wissenschaften zu Göttingen, Nr. 3, 1891.

Konow, Sten (1943)

"The Authorship of the Siva -sutras," Acta Orientalia, Vol. XIX, 1943.

Liebich, Bruno (1891)

Pānini, Ein Beitrag zur Kenntnis der Indischen

Literatur und Grammatick, Leipzig, 1891.

Limaye, V. P. (1974)

Critical Studies on the Mahābhāsya, Vishveshvarananda Indological Series, No. 49, Hoshiarpur, 1974.

Lüders, Heinrich (1894)

Die Vyāsa -śikșā, besonders in ihrem Verhaltnis zum Taittirīya $-\overline{P r a ̄ t i s ́ a ̄ k h y a, ~}$ Goöttingen, 1894.

Mimamsaka, Yudhisthir (1961-2)

Samskṛta-vyākaraṇa-śāstra kā Itihāsa, Hindi, Vol. I, revised edn., Ajmer, 1962; Vol. II, 1961.

Misra, Vidya Niwas (1966)

The Descriptive Technique of Pānini, Mouton and Co., Paris-Hague, 1966.

Nooten, van, B. A. (1973)

"The Structure of a Sanskrit Phonetic Treatise

(Apiśaliśikșā), "Acta et Commentationes Universitatis Tartuensis, Oriental Studies, Vo. II, No. 2, Tartu, U. S. S. R. , 1973.

Palsule, G. B. (1953)

"A Glimpse into the Kāsakrtsna School of Sanskrit Grammar," Proceedings and Transactions of the All India Oriental Conference, 17th Session, $1 \overline{953}$.

"The Technical Terms in the Harināmāmrta-vyākarana 
of Jĩva Gosvāmin," CASS Studies, No. 2., Publications of the Centre of Advanced Study in Sanskrit, University of Poona, Poona, 1974.

Pandeya, Rāmājñā (1965)

Vyākarana-darśana -pīthikāa, in Sanskrit, Sarasvati Bhavana Studies, Vol. XII, Banaras, 1965.

Phatak, Madhukar (1972)

Pānininya-śikșāyāh Ś Sikșāntaraị saha Samikșā, in Sanskrit, Banaras, 1972 .

Raja, Kunhan (1957)

"The Siva-sūtras of Pānini," Annals of Oriental Research, University of Madras, Vol. XIII, 1957.

Raja, Kunjunni (1963)

Indian Theories of Meaning, The Adyar Library Series, Vol. 91, Madras, 1963.

Renou, Louis (1966)

La Grammaire de Pānini, Vol. I-II, Texte Sanskrit, Traduction Française avec extraits des commentaires, École Française d'Extreme-Orient, Paris, 1966.

Sarma, K. Madhava Krishna (1968)

Pānini, Kātyāyana and Patañjali, Shri Lal Bahadur

Shastri Sanskrit Vidyapith, Delhi, 1968.

Sarma, Venkatarama (1935)

Critical Studies on Kātyāyana's Sukla Yajurveda

Prātiśākhya, University of Madras, Madras, 1935.

Scharfe, Hartmut (1961)

Die Logik im Mahābhāșya, Deutsche Akademie der

Wissenschaften zu Berlin, Institut für Orientforschung, Veröffentlichung Nr. 50, Berlin, 1961.

----(1971)

Pānini's Metalanguage, Memoirs of the American

Philosophical Society, Vol. 81, Philadelphia, 1971.

Shastri, M. D. (1926)

A Comparison of the Contents of the Rgveda, $\bar{V}$ âjasaneyi, Taittirìya and Atharva-Prātišākhyas, Princess of Wales Sarasvati Bhavana Studies, ed. by 
Gopinatha Kaviraja, Vol. V, Banaras, 1926.

Shastri, Nemichandra (1963)

Acārya Hemacandra aur unakā Śabdānuśāsana: Eka

Adhyayana, Vidyabhavana Rashtrabhasa Granthamala, No. 62, Banaras, 1963.

Sköld, Hannes (1926)

"Papers on Pānini, and Indian Grammar in General," Lunds Universitets Årsskrift, N. F. Avd. 1, Bd. 21, $\overline{\mathrm{Nr} . ~ 8}, \overline{\text { Lund, } 1926 .}$

Staal, J. F. (1972)

A Reader on the Sanskrit Grammarians, The M. I. T.

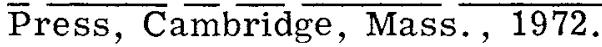

Subramonia, Venkata S. (1972)

Nārāyaña Bhațta's Prakriyā-sarvasva, a Critical

Study, Kerala University Sanskrit Department Publication, No. 7, Trivendrum, 1972.

Sukthankar, V. S. (1921)

Die Grammatik Sākațāyana's [ Addhyāya 1, Pada 1,

Neb st Yakșavarman's Kommentar Cintāmani],

Leipzig, 1921.

Thieme, Paul (1935a)

Pānini and the Veda, Allahabad, 1935.

$---(1935 b)$

"Bhāṣya zu Vārttika 5 zu Pāṇini 1.1.9 und seine einheimischen Erklärer, "Nachrichten von der Gesellschaft der Wissenschaften zu Göttingen, Philologisch-Historische Klass, Fachgruppe III, Allgemeine Sprachwissenschaft, Östlische Kultur kreise, Neue Folge, Bd. I, Nr. 5, Göttingen, 1935.

"Zur Datierung des Pānini," "Zeitschrift für Deutschen Morgenländischen Gesellschaft, Neue Folge, Bd. XIV, (Bd. 89), 1935.

$---(1937-8)$

"On the Identity of the Vārttikakāra," Indian Culture, Vol. IV, No. 2, Calcutta, 1937-8. 
$-\cdots-(1957 a)$

"Interpretation of the Learned," $\underline{\mathrm{S}} . \underline{\mathrm{K}}$. Belvalkar Felicitation Volume, Banaras, $1 \overline{95} 7$.

(1957b)

"Pānini and the Pronounciation of Sanskrit," Studies Presented to J. Whatmough on his sixtieth birthday, Gravenhage, 1957 .

$---(1957 \mathrm{c})$

"Review of W. S. Allen's Phonetics in Ancient India," Zeitschrift für Deutschen Morgenländischen Gesellschaft, Bd. 107, 1957.

$---(1958)$

"Review of the second edition of Renou's Terminologie Grammaticale du Sanskrit," Göttingische Gelehrte Anzeigen, 1958 .

Varma, Siddheshwar (1929)

The Phonetic Observations of Indian Grammarians, $\overline{\text { London, 1929, Indian Reprint Edition, Delhi, } 1961 .}$

Vasu, Satish Chandra (1891)

Asțādhyāyī of Pānini, Vols., I-II, 1891, reprint edition by Motilal Banarsidass, Delhi, 1962.

Wackernagel, Jacob (1896)

Altindische Grammatik, I. Lautlehre, Vandenhoeck and Ruprecht, Göttingen, 1896.

Walleser, Max (1927)

"Zur Aussprache von skr. a, " Zeitschrift für

Indologie und Iranistik, Band 5, Leipzig, $1 \overline{927}$.

Whitney, William Dwight (1884)

"On Lepsius's Standard Alphabet: a Letter of

Explanation from Prof. Lepsius, with notes by W. D.

Whitney," Journal of the American Oriental Society, Vol. 8, 1884-6.

Zgusta, L. (1969)

"Pānini--Descriptivist or Transformationalist?" Archiv Orientálnï, Vol. 37, No. 3, 1969. 



\section{THE UNIVERSITY OF MICHIGAN}

\section{CENTER FOR SOUTH AND SOUTHEAST ASIAN STUDIES}

\section{PUBLICATIONS}

MP 3 Norman G. Owen, ed. Compadre Colonialism: Studies on the Philippines under American Rule. Illustration, tables, bibliography. $318 \mathrm{pp}$, paper.

MP 4 Frank Shulman. Doctoral Dissertations on South Asia, 1966-70. Appendices, indexes. xvii, $228 \mathrm{pp}$., paper.

MP 5 Harley Harris Bartlett. The Labors of the Datoe and Other Essays on the Bataks of Asahan (North Sumatra). Illustrations. xxiv, $387 \mathrm{pp}$., paper.

MP 6 John Stephen Lansing. Evil in the Morning of the World: Phenomenological Approaches to a Balinese Community. Illustration, bibliography. x, $104 \mathrm{pp}$., paper.

MP 7 Thomas R. Trautmann, ed. Kinship and History in South Asia. Diagrams. ix, 157 pp., paper.

MP 8 William P. Malm and Amin Sweeney. Studies in Malaysian Oral and Musical Traditions. Illustrations. x, 104 pp., paper.

MP 9 David M. Engel. Law and Kingship in Thailand during the Reign of King Chulalongkorn. Bibliography. 131 pp., paper.

MP 10 Thomas Poffenberger. Fertility and Family Life in an Indian Village. Tables. $108 \mathrm{pp}$, , paper.

Sp 1 Thomas Powers. Balita Mula Maynila (News from Manila). Illustrations. $40 \mathrm{pp}$., paper.

LL 1 Peter Edwin Hook. .The Compound Verb in Hindi. Index, bibliography. $318 \mathrm{pp}$, , paper.

LL 2 Madhav Deshpande. Critical Studies in Indian Grammarians I: Theory of Homogeneity [Sãvarnya] . Bibliography. xiii, 223 pp., paper.

CSSEAS Publications

130 Lane Hall

The University of Michigan

Ann Arbor, Mich. 48104 


\section{ERRATA}

The reader is requested to make the following corrections

$\begin{array}{llll}\text { page: } & \text { line: } & \text { for: } & \text { read: } \\ 16 & 25 & \text { Mahākarūnāvatara } & \text { Mahākarūnāvatāra } \\ 28 & 6 & \text { Kāyavāṇ- } & \text { Kãyavān- } \\ 30 & 8 & \text { bhașyamāne } & \text { bhāṣyamāṇe } \\ " & 12 & \text { smarami } & \text { smarāmi } \\ " & 18 & \text { katam asya } & \text { katamasya } \\ " & 22 & \text { adhyabhaṣata } & \text { adhyabhāạata } \\ " & 23 & \text { bhūyasya } & \text { bhūyasyā } \\ 39 & 4 & 120 \text { scrolls } & \text { 10 scrolls } \\ 49 & 14 & \text { Fredrich } & \text { Friedrich } \\ 87 & 20 & \text { pragṛhnāti } & \text { pragṛhṇāti } \\ 234 & 22 & \text { Jam } & \text { 'Jam }\end{array}$


